Supporting Information

\title{
Matching Glycosyl Donor Reactivity to Sulfonate Leaving Group Ability Permits $S_{\mathbf{N}} 2$ Glycosylations
}

Ming-Hua Zhuo, ${ }^{1}$ David J. Wilbur, ${ }^{1}$ Eugene E. Kwan, ${ }^{*, 2}$ and Clay S. Bennett ${ }^{*, 1}$

${ }^{1}$ Department of Chemistry, Tufts University, 62 Talbot Avenue, Medford, Massachusetts 02155 , United States

${ }^{2}$ Merck \& Co., Inc., 33 Avenue Louis Pasteur, Boston, Massachusetts 02115, United States 


\section{Supporting Information}

\section{Content}

$\underline{\text { Page }}$

1. General Experiment Details

2. Materials

3. Additional Optimization Data S2

3.1 Optimization for glycosylation of donor 1 with primary acceptor $2 \quad$ S2

3.2 Optimization for glycosylation of donor $\mathbf{1}$ with primary acceptor $\mathbf{3 9}$ for kinetic isotope effect study

3.3 Optimization for glycosylation of donor $\mathbf{1}$ with secondary acceptor $\mathbf{1 2}$

4.1 Procedures for glycosylation and experimental data

4.2 Experimental data for variable temperature NMR study

4.3 Activated sulfonate donor for elimination reaction test

5. KIE Measurements

$\begin{array}{ll}5.1{ }^{13} \mathrm{C} \text { KIE measurements } & \mathrm{S} 40\end{array}$

$\begin{array}{ll}5.2 \alpha \text {-SDKIE measurements } & \text { S42 }\end{array}$

$\begin{array}{ll}\text { 5.3 Detailed characterization of disaccharide } \mathbf{4 0} & \text { S46 }\end{array}$

$\begin{array}{lr}\text { 6. DFT Calculation Procedures and Data } & \text { S48 }\end{array}$

$\begin{array}{ll}\text { 6.1. General procedures } & \text { S48 }\end{array}$

$\begin{array}{ll}\text { 6.2. Prediction of } \mathrm{S}_{\mathrm{N}} 1 \text { isotope effects } & \mathrm{S} 48\end{array}$

$\begin{array}{ll}\text { 6.3. Prediction of } \mathrm{S}_{\mathrm{N}} 2 \text { isotope effects } & \mathrm{S} 50\end{array}$

6.4. Choice of computational method for modeling $\mathrm{S}_{\mathrm{N}} 2$-like glycosylations $\quad$ S59

$\begin{array}{ll}\text { 6.5. Lowest energy structure } & \text { S67 }\end{array}$

$\begin{array}{lr}\text { 6.6. Conclusion } & \text { S69 }\end{array}$

$\begin{array}{ll}\text { 7. References } & \text { S70 }\end{array}$

$\begin{array}{lr}\text { 8. NMR Spectra } & \text { S72 }\end{array}$ 


\section{General Experiment Details}

Unless otherwise described, all reactions were performed in standard, flame-dried glassware equipped with PTFE-coated magnetic stir bars and fit with rubber septa under an inert atmosphere of argon. Flash column chromatography was performed on SiliCycle P-60 silica gel, 230-400 Mesh. Analytical and preparative thin layer chromatography (TLC) was carried out on EMD silica gel 60 F-254 plates. Products were visualized using UV or by staining with $5 \%$ aqueous sulfuric acid. NMR spectra were recorded on a Bruker Avance III NMR spectrometer at $500 \mathrm{MHz}$ for ${ }^{1} \mathrm{H}$ NMR, $125 \mathrm{MHz}$ for ${ }^{13} \mathrm{C} \mathrm{NMR}$, and $500 \mathrm{MHz}$ for Gradient HSQC and COSY. Chemical shifts are reported in ppm relative to tetramethylsilane $\left(0.00 \mathrm{ppm}\right.$ for ${ }^{1} \mathrm{H} \mathrm{NMR}$ in $\left.\mathrm{CDCl}_{3}\right)$ or $\mathrm{CDCl}_{3}\left(77.16 \mathrm{ppm}\right.$ for ${ }^{13} \mathrm{C} \mathrm{NMR}$ in $\left.\mathrm{CDCl}_{3}\right)$. For ${ }^{1} \mathrm{H} \mathrm{NMR}$ spectra, data are reported as follows: $\delta$ shift, multiplicity $[\mathrm{s}=$ singlet, $\mathrm{d}=$ doublet, $\mathrm{dd}=$ doublet of doublets, $\mathrm{m}=$ multiplet, $\mathrm{t}=$ triplet, $\mathrm{td}=$ triplet of doublets], coupling constants are reported in hertz (Hz). High-resolution mass spectra (HRMS) were obtained on Electro Spray Ionization (ESI) on a Waters Q-tof Premier instrument in the positive mode. Temperature was controlled by using Neslab CC100 immersion cooler. Optical rotations were measured on a Rudolph Research Analysis AUTOPUL IV polarimeter at $589 \mathrm{~nm}$ in a $5 \mathrm{~cm}$ at 23 ${ }^{\circ} \mathrm{C}$.

\section{Materials}

Prior to running the glycosylation reactions, all donors and acceptors were dried three times by azeotropic removal of water using toluene and a rotary evaporator and set under vacuum for $16 \mathrm{hrs}$ before use. $p$-Nitrobenzenesulfonyl chloride $4 \mathrm{~h}$ is purified before use. $4 \mathrm{~h}$ is dissolved in diethyl ether and washed with aqueous $10 \% \mathrm{NaOH}$ x 3 and brine $\mathrm{x} 1$, then dried $\left(\mathrm{Na}_{2} \mathrm{SO}_{4}\right)$ and crystalized by cooling in dry-ice bath under argon. $4 \mathrm{~h}$ is further dried over $\mathrm{P}_{2} \mathrm{O}_{5}$ in vacuum desiccator overnight. Solvents for reactions were dried on an Innovative Technologies PureSolv 400 solvent purifier. NMR solvents were purchased from Cambridge Isotope Laboratories. Glycosyl donors $\mathbf{1}^{[1]}, \mathbf{1 0} \mathbf{0}^{[1]}, \mathbf{2 9}^{[1]}, \mathbf{3 6} \mathbf{6}^{[1]}, \mathbf{6}^{[2]}, \mathbf{7}^{[2]}, \mathbf{8}^{[2]}$, and $\mathbf{3 0} \mathbf{0}^{[3]}$ and acceptors $\mathbf{2}^{[4]}, \mathbf{1 1 ^ { [ 5 ] }}, \mathbf{1 2}^{[6]}, \mathbf{1 3}^{[6]}, \mathbf{1 4}^{[6 b \text {, }}$ ${ }^{7]}, \mathbf{1 5}^{[6]}, \mathbf{1 6}^{[8]}$ and $\mathbf{3 9}^{[9]}$ were synthesized following literature procedures or variations thereof. All other chemicals were purchased at the highest possible purity from Carbosynth and Sigma-Aldrich and used as received. The $5 \mathrm{~mm}$ Low Pressure/Vacuum Valve NMR tube used for low-temperature NMR experiments was purchased from Wilmad LabGlass. Molecular sieves were activated by flame drying under vacuum three times, cooled to room temperature, and directly used for glycosylations. 


\section{Additional Optimization Data}

\subsection{Optimization for glycosylation of donor 1 with primary acceptor 2}

Table S1. Temperature and activation time optimization
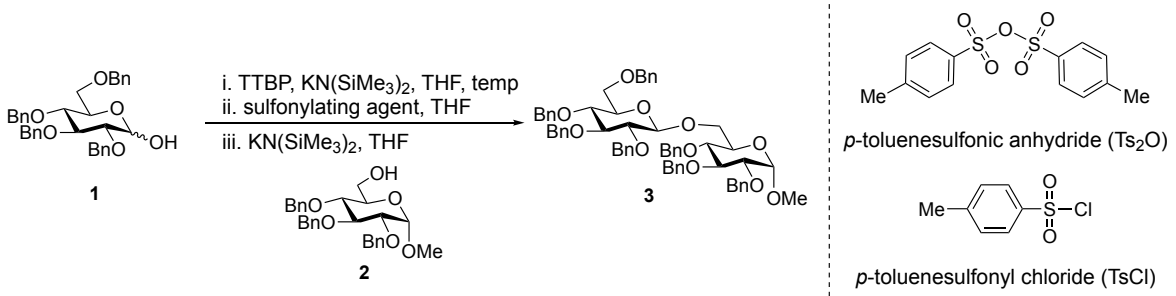

\begin{tabular}{ccccc}
\hline Entry $^{[a]}$ & Sulfonylating agent & Temp $\left[{ }^{\circ} \mathrm{C}\right]$ & Activation time $[\mathrm{h}]$ & Yield [\%] ( $\beta$ only) \\
\hline 1 & $\mathrm{Ts}_{2} \mathrm{O}$ & -78 & 0.5 & 5 \\
2 & $\mathrm{TsCl}$ & -78 & 0.5 & 6 \\
3 & $\mathrm{TsCl}$ & -35 & 0.5 & 8 \\
4 & $\mathrm{TsCl}$ & -15 & 0.5 & 25 \\
5 & $\mathrm{TsCl}$ & 0 & 0.5 & 25 \\
6 & $\mathrm{TsCl}$ & 25 & 0.5 & 7 \\
7 & $\mathrm{TsCl}$ & -15 & 1 & 25 \\
8 & $\mathrm{TsCl}$ & -15 & 1.5 & 25 \\
$\mathbf{9}$ & $\mathrm{TsCl}$ & $\mathbf{- 1 5}$ & $\mathbf{2}$ & $\mathbf{2 7}$ \\
\hline
\end{tabular}

[a] $0.20 \mathrm{mmol}$ of glucosyl donor $\mathbf{1}, 0.133 \mathrm{mmol}$ of acceptor $\mathbf{2}, 0.2 \mathrm{mmol}$ of sulfonylating agent, THF as solvent. Activation [1] $=0.080 \mathrm{M}$, glycosylation $[1]=0.050 \mathrm{M}$. Isolated yield. All selectivities based on ${ }^{1} \mathrm{H}$ NMR analysis of purified material. 
Table S2. Base and additives optimization

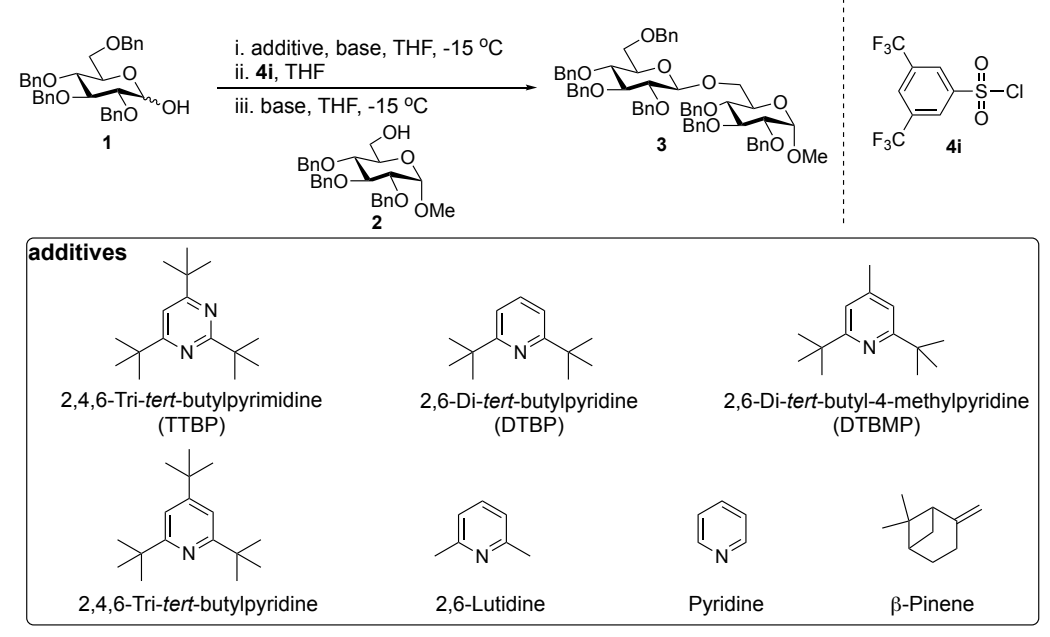

\begin{tabular}{|c|c|c|c|}
\hline Entry $^{[\mathrm{a}]}$ & Base & Additive [mmol] & Yield [\%] ( $\beta$ only) \\
\hline 1 & $\mathrm{KN}\left(\mathrm{SiMe}_{3}\right)_{2}$ & None & 24 \\
\hline 2 & $\mathrm{KN}\left(\mathrm{SiMe}_{3}\right)_{2}$ & TTBP $(0.2)$ & 46 \\
\hline 3 & $\mathrm{KN}\left(\mathrm{SiMe}_{3}\right)_{2}$ & DTBP (0.2) & 53 \\
\hline 4 & $\mathrm{KN}\left(\mathrm{SiMe}_{3}\right)_{2}$ & $\operatorname{DTBMP}(0.2)$ & 51 \\
\hline 5 & $\mathrm{KN}\left(\mathrm{SiMe}_{3}\right)_{2}$ & $\beta$-Pinene $(0.2)$ & 51 \\
\hline 6 & $\mathrm{LiN}\left(\mathrm{SiMe}_{3}\right)_{2}$ & DTBP $(0.2)$ & NR \\
\hline 7 & $\mathrm{NaN}\left(\mathrm{SiMe}_{3}\right)_{2}$ & DTBP $(0.2)$ & 74 \\
\hline 8 & $\mathrm{NaN}\left(\mathrm{SiMe}_{3}\right)_{2}$ & TTBP $(0.2)$ & 69 \\
\hline 9 & $\mathrm{NaN}\left(\mathrm{SiMe}_{3}\right)_{2}$ & DTBMP $(0.2)$ & 69 \\
\hline 10 & $\mathrm{NaN}\left(\mathrm{SiMe}_{3}\right)_{2}$ & 2,6-Lutidine $(0.2)$ & 66 \\
\hline 11 & $\mathrm{NaN}\left(\mathrm{SiMe}_{3}\right)_{2}$ & Pyridine $(0.2)$ & NR \\
\hline 12 & $\mathrm{NaN}\left(\mathrm{SiMe}_{3}\right)_{2}$ & 2,4,6-Tri-tert-butylpyridine $(0.2)$ & 76 \\
\hline 13 & $\mathrm{NaN}\left(\mathrm{SiMe}_{3}\right)_{2}$ & 2,4,6-Tri-tert-butylpyridine $(0.1)$ & 80 \\
\hline 14 & $\mathrm{NaN}\left(\mathrm{SiMe}_{3}\right)_{2}$ & 2,4,6-Tri-tert-butylpyridine (0.4) & 75 \\
\hline 15 & $\mathrm{NaN}\left(\mathrm{SiMe}_{3}\right)_{2}$ & 2,4,6-Tri-tert-butylpyridine $(0.8)$ & 69 \\
\hline 16 & $\mathrm{NaN}\left(\mathrm{SiMe}_{3}\right)_{2}$ & None & 81 \\
\hline \multicolumn{4}{|c|}{$\begin{array}{l}\text { [a] } 0.20 \mathrm{mmol} \text { of glucosyl donor } \mathbf{1}, 0.133 \mathrm{mmol} \text { of acceptor } \mathbf{2}, 0.2 \mathrm{mmol} \text { of } \\
\text { sulfonylating agent } \mathbf{4 i} \text {, THF as solvent, activation time } 2 \mathrm{hrs} \text {, Activation [1] }=0.080\end{array}$} \\
\hline \multicolumn{4}{|c|}{$\begin{array}{l}\text { M, glycosylation }[1]=0.050 \mathrm{M} \text {. Isolated yield. } \mathrm{NR}=\text { No Reaction. All selectivities } \\
\text { based on }{ }^{1} \mathrm{H} \text { NMR analysis of purified material. }\end{array}$} \\
\hline
\end{tabular}


Table S3. Solvent and additives optimization

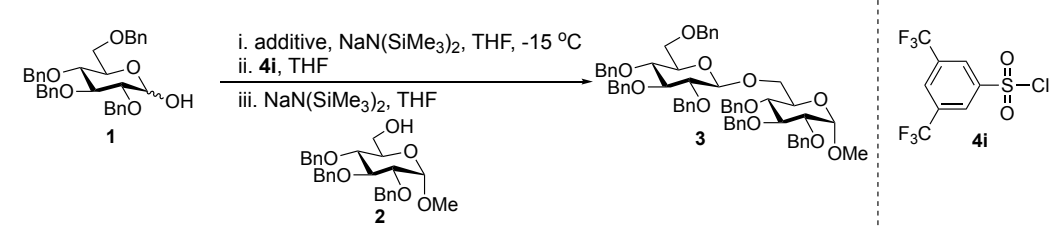

\begin{tabular}{llll}
\hline Entry ${ }^{[a]}$ & Solvent & Additive & Yield [\%] ( $\beta$ only $)$ \\
\hline 1 & THF & 2,4,6-Tri-tert-butylpyridine $(0.1 \mathrm{mmol})$ & 80 \\
2 & glyme & 2,4,6-Tri-tert-butylpyridine $(0.1 \mathrm{mmol})$ & 40 \\
3 & diglyme & 2,4,6-Tri-tert-butylpyridine $(0.1 \mathrm{mmol})$ & 20 \\
4 & $\mathrm{Et}_{2} \mathrm{O}$ & $2,4,6$-Tri-tert-butylpyridine $(0.1 \mathrm{mmol})$ & 52 \\
5 & $\mathrm{CH}_{2} \mathrm{Cl}_{2}$ & $2,4,6$-Tri-tert-butylpyridine $(0.1 \mathrm{mmol})$ & 60 \\
\hline $\mathbf{6}$ & $\mathbf{T H F}$ & None & $\mathbf{8 1}$ \\
7 & toluene & None & 60 \\
8 & $\mathrm{MeCN}$ & None & $\mathrm{NR}$ \\
9 & $\mathrm{THF} /$ toluene $=4 / 1$ & None & 63 \\
10 & $\mathrm{THF} / \mathrm{CH}_{2} \mathrm{Cl}{ }_{2}=4 / 1$ & None & 51 \\
11 & $\mathrm{THF} / 1,4-$-dioxane $=3 / 1$ & None & 52 \\
\hline 12 & $\mathrm{THF}$ & 15-Crown-5 $(0.2 \mathrm{mmol})$ & 41 \\
13 & $\mathrm{THF}$ & activated $4 \AA \mathrm{MS}(200 \mathrm{mg})$ & 68 \\
14 & $\mathrm{THF}$ & activated $5 \AA \mathrm{MS}(200 \mathrm{mg})$ & 68 \\
\hline
\end{tabular}

[a] $0.20 \mathrm{mmol}$ of glucosyl donor $\mathbf{1}, 0.133 \mathrm{mmol}$ of acceptor $\mathbf{2}, 0.2 \mathrm{mmol}$ of sulfonylating agent $\mathbf{4} \mathbf{i}$, activation time $2 \mathrm{hrs}$, activation [1] $=0.080 \mathrm{M}$, glycosylation $[\mathbf{1}]=0.050 \mathrm{M}$. Isolated yield. NR $=\mathrm{No}$ Reaction, MS $=$ Molecular Sieves. All selectivities based on ${ }^{1} \mathrm{H}$ NMR analysis of purified material. 
3.2 Optimization for glycosylation of donor 1 with primary acceptor 39 for kinetic isotope effect study

Table S4. Stoichiometry, temperature and reaction time optimization

\begin{tabular}{|c|c|c|c|c|}
\hline & 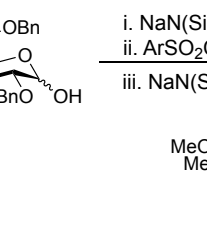 & $\begin{array}{l}\text { emp, THF } \\
\\
0 \\
0 \\
\text { OOMe }\end{array}$ & 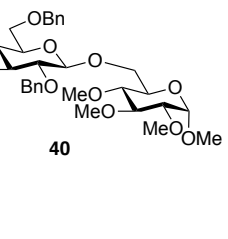 & 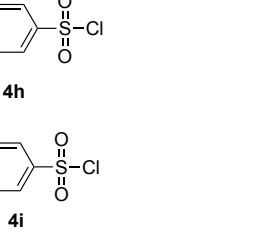 \\
\hline Entry ${ }^{[a]}$ & $\begin{array}{c}\text { Sulfonylating } \\
\text { agent }\end{array}$ & Temp $\left[{ }^{\circ} \mathrm{C}\right]$ & Reaction time & Yield [\%] ( $\beta$ only) \\
\hline $1^{[b]}$ & $4 h$ & -30 & $3 \mathrm{~h}$ & 90 \\
\hline $2^{[b]}$ & $4 \mathbf{i}$ & -30 & $3 \mathrm{~h}$ & 91 \\
\hline 3 & $4 i$ & -30 & $5 \mathrm{~min}$ & 80 \\
\hline 4 & $4 i$ & -30 & $10 \mathrm{~min}$ & 80 \\
\hline 5 & $4 i$ & -30 & $6 \mathrm{~h}$ & 82 \\
\hline 6 & $4 i$ & -30 & $12 \mathrm{~h}$ & 82 \\
\hline 7 & $4 h$ & -30 & $12 \mathrm{~h}$ & 70 \\
\hline 8 & $4 i$ & -60 & $10 \mathrm{~min}$ & 36 \\
\hline 9 & $4 \mathbf{i}$ & -60 & $20 \mathrm{~min}$ & 56 \\
\hline 10 & $4 i$ & -60 & $6 \mathrm{~h}$ & 91 \\
\hline
\end{tabular}

[a] $0.20 \mathrm{mmol}$ of glucosyl donor $\mathbf{1}, 0.2 \mathrm{mmol}$ of sulfonylating agent, $0.40 \mathrm{mmol}$ of acceptor $\mathbf{3 9}$, activation time $2 \mathrm{hrs}$, activation [1] $=0.091 \mathrm{M}$, glycosylation [1] $=0.036 \mathrm{M}$. Isolated yield. ${ }^{[b]}$ All selectivities based on ${ }^{1} \mathrm{H}$ NMR analysis of purified material. ${ }^{[b]} 0.20 \mathrm{mmol}$ of glucosyl donor $\mathbf{1}, 0.20$ mmol of sulfonylating agent, $0.1 \mathrm{mmol}$ of acceptor 39. Activation [1] $=0.080 \mathrm{M}$, glycosylation [1] = $0.057 \mathrm{M}$. 


\subsection{Optimization for glycosylation of donor 1 with secondary acceptor 12}

Table S5. Sulfonylating agent, stoichiometry, temperature and concentration optimization

\begin{tabular}{|c|c|c|c|c|c|}
\hline \multirow{2}{*}{$\begin{array}{r}\text { Bno } \\
\text { Entry } \\
\text { Ba] }\end{array}$} & \multicolumn{2}{|c|}{$\begin{array}{l}\text { i. NaN(SiMe })_{2}, \text { THF, temp } \\
\text { ii. Sulfonylating agent, THF } \\
\left.\text { iii. KN(SiMe })_{3}\right)_{2} \text {, THF }\end{array}$} & \multirow{2}{*}{ Glycosylation $[1]$} & \multirow{2}{*}{\multicolumn{2}{|c|}{ 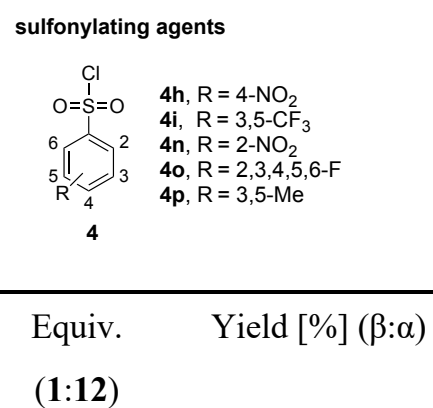 }} \\
\hline & $\begin{array}{c}\text { Sulfonylating } \\
\text { agent }\end{array}$ & Temp $\left[{ }^{\circ} \mathrm{C}\right]$ & & & \\
\hline 1 & $4 h$ & -20 & $0.057 \mathrm{M}$ & $2: 1$ & $55 \%(5: 1)$ \\
\hline 2 & $4 i$ & -20 & $0.057 \mathrm{M}$ & $2: 1$ & $73 \%(4: 1)$ \\
\hline 3 & 40 & -20 & $0.057 \mathrm{M}$ & $2: 1$ & $11 \%(2: 1)$ \\
\hline 4 & $4 p$ & -20 & $0.057 \mathrm{M}$ & $2: 1$ & Trace \\
\hline 5 & $4 n$ & -30 & $0.080 \mathrm{M}$ & $2: 1$ & $47 \%(8: 1)$ \\
\hline 6 & $4 h$ & -30 & $0.050 \mathrm{M}$ & $2: 1$ & $49 \%(10: 1)$ \\
\hline 7 & $4 h$ & -30 & $0.060 \mathrm{M}$ & $2: 1$ & $49 \%(8: 1)$ \\
\hline 8 & $4 h$ & -30 & $0.070 \mathrm{M}$ & $2: 1$ & $53 \%(6: 1)$ \\
\hline 9 & $4 h$ & -30 & $0.057 \mathrm{M}$ & $3: 1$ & $59 \%(14: 1)$ \\
\hline $10^{[b]}$ & $4 h$ & -30 & $0.057 \mathrm{M}$ & $3: 1$ & $60 \%(14: 1)$ \\
\hline 11 & $4 i$ & -40 & $0.057 \mathrm{M}$ & $3: 1$ & $56 \%(14: 1)$ \\
\hline $12^{[b]}$ & $4 i$ & -40 & $0.057 \mathrm{M}$ & $3: 1$ & $58 \%(14: 1)$ \\
\hline
\end{tabular}




\section{Experimental Data}

\subsection{Procedures for glycosylation and experimental data}

General glycosylation procedure: A solution of donor in THF was cooled to identical temperature and treated with sodium hexamethyldisilazane (1.0 M in THF). After 10 mindutes, this solution was transferred by syringe to a flask containing the solution of promoter sulfonyl chloride in THF that had been pre-cooled to the same temperature. The flask that contained the donor was then rinsed with an additional THF, and this rinse was then added to the donor and sulfonyl chloride reaction mixture. After this mixture has stirred for two hours, it was treated with a freshly prepared solution of the alkoxide acceptor (prepared by treating a solution of acceptor in THF at the same temperature with sodium hexamethyldisilazane or potassium hexamethyldisilazane and stirring for 10 minutes.). The flask that had contained the acceptor was rinsed with THF, and this rinse was then added to the glycosylation reaction.

Work-up procedure: The reaction was quenched with saturated aqueous ammonium chloride $\left(\mathrm{NH}_{4} \mathrm{Cl}\right)$, diluted with water, and extracted with diethyl ether four times. The combined organic phase was washed with brine and then dried $\left(\mathrm{Na}_{2} \mathrm{SO}_{4}\right)$, filtered, and concentrated under reduced pressure.

Yield and selectivity determination: The crude reaction mixture was purified by silica gel flash column chromatography to afford $\beta$ and $\alpha$ products. The selectivity was determined by ${ }^{1} \mathrm{H}$ NMR integration of the anomeric signals. If the $\beta$ and $\alpha$ products did not separate significantly on silica gel, and care was taken to isolate the entire chromatographic band.

\section{Methyl 2,3,4-O-tribenzyl-6-O-(2,3,4,6-O-tetrabenzyl- $\beta$-D-glucopyranosyl)- $\alpha$-D- glucopyranoside 3}

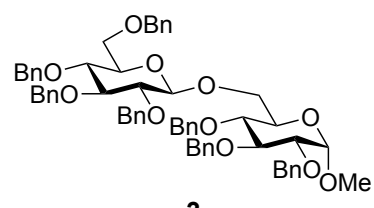

3

A solution of donor $1(0.1080 \mathrm{~g}, 0.2 \mathrm{mmol}, 2$ equiv. $)$ in $1.0 \mathrm{~mL}$ of THF was cooled to $30{ }^{\circ} \mathrm{C}$ and treated with sodium hexamethyldisilazane $(1 \mathrm{M}$ in THF, $0.2 \mathrm{~mL}, 0.2 \mathrm{mmol}$, 2 equiv.). After 10 minutes, this solution was transferred by syringe to a flask containing the solution of either $p$-nitrobenzenesulfonyl chloride $4 \mathbf{h}(0.0442 \mathrm{~g}, 0.2 \mathrm{mmol}, 2$ equiv.) or 3,5-bis(trifluoromethyl)benzenesulfonyl chloride $4 \mathbf{i}(0.0623 \mathrm{~g}, 0.2 \mathrm{mmol}, 2$ equiv.) in $1.0 \mathrm{~mL}$ of THF that had been pre-cooled to $-30^{\circ} \mathrm{C}$. The flask that contained the donor was then rinsed with an additional $0.5 \mathrm{~mL}$ of THF, and this rinse was then added to the 
donor and sulfonyl chloride reaction mixture. After this mixture has stirred for two hours at $-30^{\circ} \mathrm{C}$, it was treated with a freshly prepared solution of the alkoxide acceptor (prepared by treating a solution of acceptor $2(0.0464 \mathrm{~g}, 0.1 \mathrm{mmol}, 1$ equiv.) in $0.5 \mathrm{~mL}$ of THF at $-30{ }^{\circ} \mathrm{C}$ with sodium hexamethyldisilazane $(0.1 \mathrm{~mL}, 0.1 \mathrm{mmol}, 1$ equiv.) and stirring for 10 minutes.). The flask that had contained the acceptor was rinsed with 0.5 $\mathrm{mL}$ of THF, and this rinse was then added to the glycosylation reaction. After 3 hours, the reaction was quenched with $0.05 \mathrm{~mL}$ of saturated aqueous ammonium chloride $\left(\mathrm{NH}_{4} \mathrm{Cl}\right)$, diluted with water, and extracted with diethyl ether $(4 \times 10 \mathrm{~mL})$. The combined organic phase was washed with brine $(20 \mathrm{~mL})$ and then dried $\left(\mathrm{Na}_{2} \mathrm{SO}_{4}\right)$, filtered, and concentrated under reduced pressure. The crude product was purified by silica gel flash column chromatography (15\% ethyl acetate in hexane) to afford disaccharide 3 as a single $\beta$-isomer ( $0.0836 \mathrm{~g}, 0.085 \mathrm{mmol}, 85 \%$ yield $)$ when $\mathbf{4 h}$ was used as the promoter or $(0.0947 \mathrm{~g}, 0.096 \mathrm{mmol}, 96 \%$ yield $)$ when $4 \mathbf{i}$ was used as the promoter.

${ }^{1} \mathbf{H}$ NMR $\left(500 \mathrm{MHz}, \mathrm{CDCl}_{3}\right) \delta 7.35-7.11(\mathrm{~m}, 35 \mathrm{H}), 4.98(\mathrm{~d}, J=4.0 \mathrm{~Hz}, 1 \mathrm{H}), 4.95(\mathrm{~d}$, $J=3.9 \mathrm{~Hz}, 1 \mathrm{H}), 4.90(\mathrm{~d}, J=10.9 \mathrm{~Hz}, 1 \mathrm{H}), 4.83-4.69(\mathrm{~m}, 6 \mathrm{H}), 4.65(\mathrm{~d}, J=12.1 \mathrm{~Hz}$, $1 \mathrm{H}), 4.60(\mathrm{~d}, J=3.1 \mathrm{~Hz}, 1 \mathrm{H}), 4.58-4.49(\mathrm{~m}, 4 \mathrm{H}), 4.34(\mathrm{~d}, J=7.8 \mathrm{~Hz}, 1 \mathrm{H}), 4.18(\mathrm{dd}$, $J=10.8,1.8 \mathrm{~Hz}, 1 \mathrm{H}), 3.99(\mathrm{t}, J=9.3 \mathrm{~Hz}, 1 \mathrm{H}), 3.84-3.81(\mathrm{~m}, 1 \mathrm{H}), 3.70-3.63(\mathrm{~m}$, $3 \mathrm{H}), 3.61(\mathrm{~d}, J=9.0 \mathrm{~Hz}, 1 \mathrm{H}), 3.56(\mathrm{t}, J=9.3 \mathrm{~Hz}, 1 \mathrm{H}), 3.53-3.45(\mathrm{~m}, 3 \mathrm{H}), 3.45-3.40$ (m, 1H), $3.32(\mathrm{~s}, 3 \mathrm{H})$.

${ }^{13}$ C NMR $\left(125 \mathrm{MHz}, \mathrm{CDCl}_{3}\right) \delta 139.0,138.7,138.5,138.5,138.4,138.3,138.3,128.6$, $128.5,128.5,128.5,128.3,128.1,128.1,128.0,128.0,127.9,127.8,127.7,127.7,127.7$, 127.6, 104.0, 98.2, 84.9, 82.2, 82.1, 79.9, 78.2, 78.1, 75.8, 75.8, 75.2, 75.1, 75.0, 73.6, 73.5, 70.0, 69.2, 68.7, 55.3. The ${ }^{1} \mathrm{H}$ NMR and ${ }^{13} \mathrm{C}$ NMR spectra coincide with the previous report. ${ }^{[10]}$

\section{6-O-(2,3,4,6-O-tetrabenzyl- $\beta$-D-galactopyranosyl)-1,2;3,4-O-diisopropylidene- $\alpha$ -}

\section{D-galactopyranoside 17}

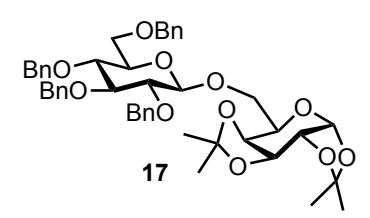

A solution of donor 1 ( $0.2160 \mathrm{~g}, 0.4 \mathrm{mmol}, 3$ equiv.) in $2.0 \mathrm{~mL}$ of THF was cooled to $30{ }^{\circ} \mathrm{C}$ and treated with sodium hexamethyldisilazane ( $1 \mathrm{M}$ in THF, $0.4 \mathrm{~mL}, 0.4 \mathrm{mmol}$, 3 equiv.). After 10 minutes, this solution was transferred by syringe to a flask containing the solution of either $p$-nitrobenzenesulfonyl chloride $4 \mathbf{h}(0.0884 \mathrm{~g}, 0.4 \mathrm{mmol}, 3$ equiv.) or 3,5-bis(trifluoromethyl)benzenesulfonyl chloride $4 \mathbf{i}$ ( $0.1246 \mathrm{~g}, 0.4 \mathrm{mmol}, 3$ equiv.) in $2.0 \mathrm{~mL}$ of THF that had been pre-cooled to $-30^{\circ} \mathrm{C}$. The flask that contained the donor was then rinsed with an additional $1.0 \mathrm{~mL}$ of THF, and this rinse was then added to the 
donor and sulfonyl chloride reaction mixture. After this mixture has stirred for two hours at $-30^{\circ} \mathrm{C}$, it was treated with a freshly prepared solution of the alkoxide acceptor (prepared by treating a solution of acceptor 11 ( $0.0347 \mathrm{~g}, 0.133 \mathrm{mmol}, 1$ equiv.) in 1.4 $\mathrm{mL}$ of $\mathrm{THF}$ at $-30{ }^{\circ} \mathrm{C}$ with sodium hexamethyldisilazane $(0.133 \mathrm{~mL}, 0.133 \mathrm{mmol}, 1$ equiv.) and stirring for 10 minutes.). The flask that had contained the acceptor was rinsed with $0.6 \mathrm{~mL}$ of THF, and this rinse was then added to the glycosylation reaction. After 4 hours, the reaction was quenched with $0.1 \mathrm{~mL}$ of saturated, aqueous ammonium chloride $\left(\mathrm{NH}_{4} \mathrm{Cl}\right)$, diluted with water, and extracted with diethyl ether $(4 \times 15 \mathrm{~mL})$. The combined organic phase was washed with brine $(30 \mathrm{~mL})$ and then dried $\left(\mathrm{Na}_{2} \mathrm{SO}_{4}\right)$, filtered, and concentrated under reduced pressure. The crude product was purified by silica gel flash column chromatography (15\% ethyl acetate in hexane) to afford disaccharide 17 (0.0739 g, $0.094 \mathrm{mmol}, 71 \%$ yield, $\beta: \alpha$ 17:1) when $4 \mathrm{~h}$ was used as the promoter or $(0.0957 \mathrm{~g}, 0.122 \mathrm{mmol}, 92 \%$ yield, $\beta: \alpha 10: 1)$ when $4 \mathbf{i}$ was used as the promoter. The selectivity was determined by ${ }^{1} \mathrm{H}$ NMR integration of the anomeric signals of purified 17 . The $\beta$ and $\alpha$ products did not separate significantly on silica gel, and care was taken to isolate the entire chromatographic band.

\section{及-isomer}

${ }^{1} \mathbf{H}$ NMR (500 MHz, $\left.\mathrm{CDCl}_{3}\right) \delta 7.45-7.07(\mathrm{~m}, 20 \mathrm{H}), 5.57(\mathrm{~d}, J=5.0 \mathrm{~Hz}, 1 \mathrm{H}), 5.06(\mathrm{~d}$, $J=11.1 \mathrm{~Hz}, 1 \mathrm{H}), 4.96(\mathrm{~d}, J=10.9 \mathrm{~Hz}, 1 \mathrm{H}), 4.82-4.76(\mathrm{~m}, 2 \mathrm{H}), 4.72(\mathrm{~d}, J=11.1 \mathrm{~Hz}$, $1 \mathrm{H}), 4.64-4.56(\mathrm{~m}, 2 \mathrm{H}), 4.55-4.47(\mathrm{~m}, 2 \mathrm{H}), 4.46(\mathrm{~d}, J=7.8 \mathrm{~Hz}, 1 \mathrm{H}), 4.31$ (dd, $J=$ 5.0, $2.4 \mathrm{~Hz}, 1 \mathrm{H}), 4.24$ (dd, $J=7.9,1.7 \mathrm{~Hz}, 1 \mathrm{H}), 4.16(\mathrm{dd}, J=10.7,3.6 \mathrm{~Hz}, 1 \mathrm{H}), 4.11-$ $4.06(\mathrm{~m}, 1 \mathrm{H}), 3.75-3.67(\mathrm{~m}, 3 \mathrm{H}), 3.66-3.58(\mathrm{~m}, 2 \mathrm{H}), 3.50-3.39(\mathrm{~m}, 2 \mathrm{H}), 1.50(\mathrm{~s}$, $3 \mathrm{H}), 1.45(\mathrm{~s}, 3 \mathrm{H}), 1.31(\mathrm{~d}, J=2.7 \mathrm{~Hz}, 6 \mathrm{H})$.

${ }^{13}$ C NMR $\left(125 \mathrm{MHz}, \mathrm{CDCl}_{3}\right) \delta 138.8,138.2,128.7,128.4,128.4,128.3,128.0,127.9$, $127.9,127.7,127.6,127.6,127.5,109.4,108.6,104.4,96.4,84.6,81.7,77.8,75.7,75.0$, $74.8,74.4,73.5,71.5,70.8,70.5,69.8,68.8,67.4,26.1,26.0,25.1,24.5$. The ${ }^{1} \mathrm{H}$ NMR and ${ }^{13} \mathrm{C}$ NMR spectra coincide with the previous report. ${ }^{[1]}$

\section{$\alpha$-isomer}

${ }^{1} \mathbf{H}$ NMR $\left(500 \mathrm{MHz}, \mathrm{CDCl}_{3}\right) \delta 7.41-7.05(\mathrm{~m}, 20 \mathrm{H}), 5.52(\mathrm{~d}, J=5.0 \mathrm{~Hz}, 1 \mathrm{H}), 5.00-$ $4.97(\mathrm{~m}, 2 \mathrm{H}), 4.81(\mathrm{t}, J=10.6 \mathrm{~Hz}, 2 \mathrm{H}), 4.75(\mathrm{~d}, J=11.9 \mathrm{~Hz}, 1 \mathrm{H}), 4.69$ (d, $J=11.9 \mathrm{~Hz}$, $1 \mathrm{H}), 4.64-4.57(\mathrm{~m}, 2 \mathrm{H}), 4.48(\mathrm{~d}, J=4.3 \mathrm{~Hz}, 1 \mathrm{H}), 4.46(\mathrm{~d}, J=5.7 \mathrm{~Hz}, 1 \mathrm{H}), 4.35(\mathrm{dd}$, $J=8.0,1.7 \mathrm{~Hz}, 1 \mathrm{H}), 4.31(\mathrm{dd}, J=5.0,2.3 \mathrm{~Hz}, 1 \mathrm{H}), 4.04(\mathrm{t}, J=6.9 \mathrm{~Hz}, 1 \mathrm{H}), 3.98$ (t, $J$ $=9.3 \mathrm{~Hz}, 1 \mathrm{H}), 3.85-3.71(\mathrm{~m}, 4 \mathrm{H}), 3.71-3.62(\mathrm{~m}, 2 \mathrm{H}), 3.58(\mathrm{dd}, J=9.6,3.6 \mathrm{~Hz}, 1 \mathrm{H})$, $1.53(\mathrm{~s}, 3 \mathrm{H}), 1.45(\mathrm{~s}, 3 \mathrm{H}), 1.32(\mathrm{~d}, J=6.8 \mathrm{~Hz}, 6 \mathrm{H})$.

${ }^{13}$ C NMR $\left(125 \mathrm{MHz}, \mathrm{CDCl}_{3}\right) \delta 139.1,138.5,138.5,138.2,128.5,128.1,128.0,128.0$, $127.8,127.8,127.7,109.4,108.7,97.2,96.5,82.1,80.0,77.8,77.4,77.2,76.9,75.8$, 
75.1, 73.6, 72.5, 71.0, 70.9, 70.8, 70.4, 68.6, 66.4, 65.9, 26.3, 26.2, 25.1, 24.8. The ${ }^{1} \mathrm{H}$ $\mathrm{NMR}$ and ${ }^{13} \mathrm{C}$ NMR spectra coincide with the previous report. ${ }^{[12]}$

Methyl 6-O-(4-O-(2-naphthylmethyl)-2,3,6-tri-O-benzyl- $\beta$-D-glucopyranosyl)2,3,4-tri-O-benzyl- $\alpha$-D-glucopyranoside 18

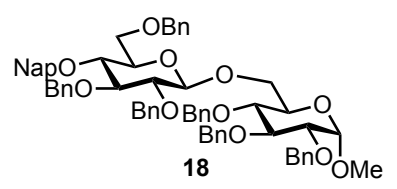

A solution of donor 5 ( $0.1180 \mathrm{~g}, 0.2 \mathrm{mmol}, 2$ equiv. $)$ in $1.0 \mathrm{~mL}$ of THF was cooled to $30{ }^{\circ} \mathrm{C}$ and treated with sodium hexamethyldisilazane $(1 \mathrm{M}$ in THF, $0.2 \mathrm{~mL}, 0.2 \mathrm{mmol}$, 2 equiv.). After 10 minutes, this solution was transferred by syringe to a flask containing the solution of either $p$-nitrobenzenesulfonyl chloride $4 \mathbf{h}(0.0442 \mathrm{~g}, 0.2 \mathrm{mmol}, 2$ equiv. $)$ or 3,5-bis(trifluoromethyl)benzenesulfonyl chloride $4 \mathbf{i}(0.0623 \mathrm{~g}, 0.2 \mathrm{mmol}, 2$ equiv.) in $1.0 \mathrm{~mL}$ of THF that had been pre-cooled to $-30{ }^{\circ} \mathrm{C}$. The flask that contained the donor was then rinsed with an additional $0.5 \mathrm{mLof} \mathrm{THF}$, and this rinse was then added to the donor and sulfonyl chloride reaction mixture. After this mixture has stirred for two hours at $-30{ }^{\circ} \mathrm{C}$, it was treated with a freshly prepared solution of the alkoxide acceptor (prepared by treating a solution of acceptor $2(0.0464 \mathrm{~g}, 0.1 \mathrm{mmol}, 1$ equiv.) in $0.5 \mathrm{~mL}$ of THF at $-30{ }^{\circ} \mathrm{C}$ with sodium hexamethyldisilazane $(0.1 \mathrm{~mL}, 0.1 \mathrm{mmol}, 1$ equiv.) and stirring for 10 minutes.). The flask that had contained the acceptor was rinsed with 0.5 $\mathrm{mL}$ of THF, and this rinse was then added to the glycosylation reaction. After 3 hours, the reaction was quenched with $0.05 \mathrm{~mL}$ of saturated aqueous ammonium chloride $\left(\mathrm{NH}_{4} \mathrm{Cl}\right)$, diluted with water, and extracted with diethyl ether $(4 \times 10 \mathrm{~mL})$. The combined organic phase was washed with brine $(20 \mathrm{~mL})$ and then dried $\left(\mathrm{Na}_{2} \mathrm{SO}_{4}\right)$, filtered, and concentrated under reduced pressure. The crude product was purified by silica gel flash column chromatography (17\% ethyl acetate in hexane) to afford disaccharide 18 as a single $\beta$-isomer (0.0556 g, $0.054 \mathrm{mmol}, 54 \%$ yield) when $\mathbf{4 h}$ was used as the promoter or ( $0.0713 \mathrm{~g}, 0.069 \mathrm{mmol}, 69 \%$ yield) when $4 \mathbf{i}$ was used as the promoter.

$[\alpha]_{\mathbf{D}}{ }^{22}=+21.8^{\circ}\left(c 1.2, \mathrm{CH}_{2} \mathrm{Cl}_{2}\right)$;

${ }^{1} \mathbf{H}$ NMR $\left(500 \mathrm{MHz}, \mathrm{CDCl}_{3}\right) \delta 7.84-7.68(\mathrm{~m}, 3 \mathrm{H}), 7.59(\mathrm{~s}, 1 \mathrm{H}), 7.47-7.45(\mathrm{~m}, 2 \mathrm{H})$, $7.39-7.12(\mathrm{~m}, 31 \mathrm{H}), 4.99-4.91(\mathrm{~m}, 4 \mathrm{H}), 4.85-4.56(\mathrm{~m}, 9 \mathrm{H}), 4.56-4.43(\mathrm{~m}, 2 \mathrm{H})$, $4.36(\mathrm{~d}, J=7.8 \mathrm{~Hz}, 1 \mathrm{H}), 4.18(\mathrm{~d}, J=9.7 \mathrm{~Hz}, 1 \mathrm{H}), 3.99(\mathrm{t}, J=9.2 \mathrm{~Hz}, 1 \mathrm{H}), 3.88-3.79$ $(\mathrm{m}, 1 \mathrm{H}), 3.79-3.56(\mathrm{~m}, 5 \mathrm{H}), 3.56-3.40(\mathrm{~m}, 4 \mathrm{H}), 3.32(\mathrm{~s}, 3 \mathrm{H})$.

${ }^{13}$ C NMR (125 MHz, $\left.\mathrm{CDCl}_{3}\right) \delta 138.9,138.6,138.4,138.4,138.3,138.2,135.6,133.3$, $133.0,128.5,128.4,128.4,128.3,128.1,128.1,128.0,127.9,127.9,127.9,127.7,127.6$, 
$127.6,127.6,127.5,127.5,126.6,126.1,126.0,125.9,103.9,98.1,84.9,82.1,82.0$, $79.8,78.1,78.0,75.7,75.7,75.1,75.0,74.9,73.5,73.4,69.9,69.1,68.6,55.2$.

LRMS (ESI) m/z: calculated for $\mathrm{C}_{66} \mathrm{H}_{68} \mathrm{NaO}_{11}(\mathrm{M}+\mathrm{Na})=1059.46$; found 1059.62;

HRMS (ESI) m/z: calculated for $\mathrm{C}_{66} \mathrm{H}_{68} \mathrm{NaO}_{11}(\mathrm{M}+\mathrm{Na})=1059.4659$; found 1059.4613

\section{Methyl 6-O-(4-O-Benzoyl-2,3,6-tri- $O$-benzyl- $\beta$-D-glucopyranosyl)-2,3,4-tri- $O$ - benzyl-a-D-glucopyranoside 19}

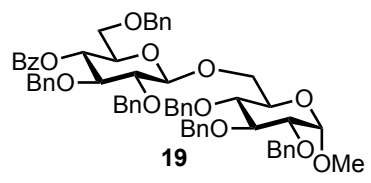

A solution of donor $6(0.1108 \mathrm{~g}, 0.2 \mathrm{mmol}, 2$ equiv. $)$ in $1.0 \mathrm{~mL}$ of THF was cooled to $30{ }^{\circ} \mathrm{C}$ and treated with sodium hexamethyldisilazane $(1 \mathrm{M}$ in THF, $0.2 \mathrm{~mL}, 0.2 \mathrm{mmol}$, 2 equiv.). After 10 minutes, this solution was transferred by syringe to a flask containing the solution of either $p$-nitrobenzenesulfonyl chloride $4 \mathbf{h}(0.0442 \mathrm{~g}, 0.2 \mathrm{mmol}, 2$ equiv.) or 3,5-bis(trifluoromethyl)benzenesulfonyl chloride $4 \mathbf{i}(0.0623 \mathrm{~g}, 0.2 \mathrm{mmol}, 2$ equiv.) in $1.0 \mathrm{~mL}$ of THF that had been pre-cooled to $-30^{\circ} \mathrm{C}$. The flask that contained the donor was then rinsed with an additional $0.5 \mathrm{mLof}$ THF, and this rinse was then added to the donor and sulfonyl chloride reaction mixture. After this mixture has stirred for two hours at $-30^{\circ} \mathrm{C}$, it was treated with a freshly prepared solution of the alkoxide acceptor (prepared by treating a solution of acceptor $2(0.0464 \mathrm{~g}, 0.1 \mathrm{mmol}, 1$ equiv.) in $0.5 \mathrm{~mL}$ of THF at $-30{ }^{\circ} \mathrm{C}$ with sodium hexamethyldisilazane $(0.1 \mathrm{~mL}, 0.1 \mathrm{mmol}, 1$ equiv.) and stirring for 10 minutes.). The flask that had contained the acceptor was rinsed with 0.5 $\mathrm{mL}$ of THF, and this rinse was then added to the glycosylation reaction. After 5 hours, the reaction was quenched with $0.05 \mathrm{~mL}$ of saturated aqueous ammonium chloride $\left(\mathrm{NH}_{4} \mathrm{Cl}\right)$, diluted with water, and extracted with diethyl ether $(4 \times 10 \mathrm{~mL})$. The combined organic phase was washed with brine $(20 \mathrm{~mL})$ and then dried $\left(\mathrm{Na}_{2} \mathrm{SO}_{4}\right)$, filtered, and concentrated under reduced pressure. The crude product was purified by silica gel flash column chromatography (15\% ethyl acetate in hexane) to afford disaccharide 19 as a single $\beta$-isomer $(0.0821 \mathrm{~g}, 0.082 \mathrm{mmol}, 82 \%$ yield) when $\mathbf{4 h}$ was used as the promoter or $(0.0889 \mathrm{~g}, 0.089 \mathrm{mmol}, 90 \%$ yield $)$ when $4 \mathbf{i}$ was used as the promoter.

${ }^{1} \mathbf{H}$ NMR $\left(500 \mathrm{MHz}, \mathrm{CDCl}_{3}\right) \delta 7.98-7.85(\mathrm{~m}, 2 \mathrm{H}), 7.56(\mathrm{dd}, J=10.6,4.3 \mathrm{~Hz}, 1 \mathrm{H})$, $7.41(\mathrm{t}, J=7.8 \mathrm{~Hz}, 2 \mathrm{H}), 7.37-7.22(\mathrm{~m}, 16 \mathrm{H}), 7.22-7.09(\mathrm{~m}, 11 \mathrm{H}), 7.12-6.97(\mathrm{~m}$, $5 \mathrm{H}), 5.21(\mathrm{t}, J=9.6 \mathrm{~Hz}, 1 \mathrm{H}), 4.97(\mathrm{~d}, J=10.9 \mathrm{~Hz}, 2 \mathrm{H}), 4.81-4.69(\mathrm{~m}, 5 \mathrm{H}), 4.68-$ $4.57(\mathrm{~m}, 3 \mathrm{H}), 4.52(\mathrm{~d}, J=11.2 \mathrm{~Hz}, 1 \mathrm{H}), 4.45(\mathrm{dd}, J=7.8,4.9 \mathrm{~Hz}, 3 \mathrm{H}), 4.20(\mathrm{dd}, J=$ 
$1.9,1.8 \mathrm{~Hz}, 1 \mathrm{H}), 4.00(\mathrm{t}, J=9.3 \mathrm{~Hz}, 1 \mathrm{H}), 3.87-3.81(\mathrm{~m}, 1 \mathrm{H}), 3.75-3.71(\mathrm{~m}, 2 \mathrm{H}), 3.70$ - $3.62(\mathrm{~m}, 1 \mathrm{H}), 3.62-3.58(\mathrm{~m}, 3 \mathrm{H}), 3.57-3.49(\mathrm{~m}, 2 \mathrm{H}), 3.34(\mathrm{~s}, 3 \mathrm{H})$.

${ }^{13}$ C NMR (125 MHz, $\left.\mathrm{CDCl}_{3}\right) \delta 165.4,138.9,138.4,138.3,138.2,137.9,133.2,129.8$, $129.7,128.5,128,4,128.4,128.3,128.2,128.1,128.0,127.9,127.9,127.9,127.6,127.6$, $127.6,127.5,127.5,127.5,103.7,98.1,82.0,81.9,81.7,79.9,78.0,75.7,75.1,75.0$, 74.9, 73.8, 73.6, 73.4, 71.6, 69.9, 69.8, 68.6, 55.2. The ${ }^{1} \mathrm{H}$ NMR and ${ }^{13} \mathrm{C}$ NMR spectra coincide with the previous report. ${ }^{[2,13]}$

Methyl 6-O-(3-O-benzoyl-2,3,6-tri- $O$-benzyl- $\beta$-D-glucopyranosyl)-2,3,4-tri- $O$ benzyl- $\alpha$-D-glucopyranoside 20

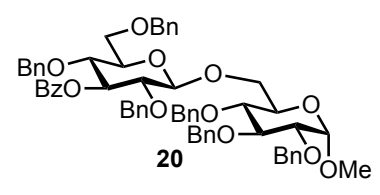

A solution of donor 7 ( $0.1108 \mathrm{~g}, 0.2 \mathrm{mmol}, 2$ equiv.) in $1.0 \mathrm{~mL}$ of THF was cooled to $30{ }^{\circ} \mathrm{C}$ and treated with sodium hexamethyldisilazane ( $1 \mathrm{M}$ in THF, $0.2 \mathrm{~mL}, 0.2 \mathrm{mmol}$, 2 equiv.). After 10 minutes, this solution was transferred by syringe to a flask containing the solution of either $p$-nitrobenzenesulfonyl chloride $4 \mathbf{h}$ ( $0.0442 \mathrm{~g}, 0.2 \mathrm{mmol}, 2$ equiv.) or 3,5-bis(trifluoromethyl)benzenesulfonyl chloride $4 \mathbf{i}$ ( $0.0623 \mathrm{~g}, 0.2 \mathrm{mmol}, 2$ equiv.) in $1.0 \mathrm{~mL}$ of THF that had been pre-cooled to $-30{ }^{\circ} \mathrm{C}$. The flask that contained the donor was then rinsed with an additional $0.5 \mathrm{~mL}$ of THF, and this rinse was then added to the donor and sulfonyl chloride reaction mixture. After this mixture has stirred for two hours at $-30{ }^{\circ} \mathrm{C}$, it was treated with a freshly prepared solution of the alkoxide acceptor (prepared by treating a solution of acceptor $2(0.0464 \mathrm{~g}, 0.1 \mathrm{mmol}, 1$ equiv.) in $0.5 \mathrm{~mL}$ of THF at $-30{ }^{\circ} \mathrm{C}$ with sodium hexamethyldisilazane $(0.1 \mathrm{~mL}, 0.1 \mathrm{mmol}, 1$ equiv.) and stirring for 10 minutes.). The flask that had contained the acceptor was rinsed with 0.5 $\mathrm{mL}$ of THF, and this rinse was then added to the glycosylation reaction. After 5 hours, the reaction was quenched with $0.05 \mathrm{~mL}$ of saturated aqueous ammonium chloride $\left(\mathrm{NH}_{4} \mathrm{Cl}\right)$, diluted with water, and extracted with diethyl ether $(4 \times 10 \mathrm{~mL})$. The combined organic phase was washed with brine $(20 \mathrm{~mL})$ and then dried $\left(\mathrm{Na}_{2} \mathrm{SO}_{4}\right)$, filtered, and concentrated under reduced pressure. The crude product was purified by silica gel flash column chromatography (18\% ethyl acetate in hexane) to afford disaccharide 20 as a single $\beta$-isomer $(0.0329 \mathrm{~g}, 0.033 \mathrm{mmol}, 33 \%$ yield $)$ when $\mathbf{4 h}$ was used as the promoter or ( $0.0652 \mathrm{~g}, 0.065 \mathrm{mmol}, 65 \%$ yield) when $4 \mathbf{i}$ was used as the promoter.

${ }^{1} \mathbf{H}$ NMR $\left(500 \mathrm{MHz}, \mathrm{CDCl}_{3}\right) \delta 7.93(\mathrm{~d}, J=7.3 \mathrm{~Hz}, 2 \mathrm{H}), 7.55(\mathrm{t}, J=7.4 \mathrm{~Hz}, 1 \mathrm{H}), 7.44$ $-6.90(\mathrm{~m}, 32 \mathrm{H}), 5.48(\mathrm{t}, J=9.4 \mathrm{~Hz}, 1 \mathrm{H}), 4.98(\mathrm{~d}, J=10.9 \mathrm{~Hz}, 1 \mathrm{H}), 4.85-4.72(\mathrm{~m}$, $4 \mathrm{H}), 4.69-4.56(\mathrm{~m}, 5 \mathrm{H}), 4.54-4.52(\mathrm{~m}, 2 \mathrm{H}), 4.49-4.38(\mathrm{~m}, 3 \mathrm{H}), 4.18$ (dd, $J=10.8$, 
$1.5 \mathrm{~Hz}, 1 \mathrm{H}), 4.01$ (t, $J=9.3 \mathrm{~Hz}, 1 \mathrm{H}), 3.84(\mathrm{dd}, J=10.0,3.2 \mathrm{~Hz}, 1 \mathrm{H}), 3.77-3.63(\mathrm{~m}$, $4 \mathrm{H}), 3.60-3.46(\mathrm{~m}, 4 \mathrm{H}), 3.36(\mathrm{~s}, 3 \mathrm{H})$.

${ }^{13}$ C NMR $\left(125 \mathrm{MHz}, \mathrm{CDCl}_{3}\right) \delta 165.6,138.8,138.3,138.2,137.8,137.5,133.0,130.1$, $129.8,128.5,128.5,128.4,128.4,128.3,128.3,128.2,128.2,128.1,128.1,128.0,128.0$, $127.8,127.8,127.7,127.7,127.7,127.6,127.5,103.8,98.1,82.0,79.9,78.9,78.1,76.5$, 76.1, 75.8, 75.0, 74.9, 74.5, 74.3, 73.6, 73.4, 70.1, 68.7, 68.6, 55.3. The ${ }^{1} \mathrm{H}$ NMR and ${ }^{13} \mathrm{C}$ NMR spectra coincide with the previous report. ${ }^{[2]}$

\section{Methyl 6-O-(4-O-acetyl-2,3,6-tri- $O$-benzyl- $\beta$-D-glucopyranosyl)-2,3,4-tri- $O$ - benzyl- $\alpha$-D-glucopyranoside 21}

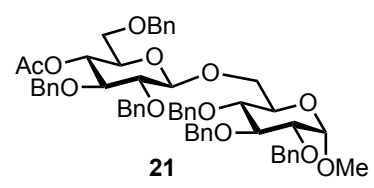

A solution of donor 8 ( $0.0984 \mathrm{~g}, 0.2 \mathrm{mmol}, 2$ equiv.) in $1.0 \mathrm{~mL}$ of THF was cooled to $30{ }^{\circ} \mathrm{C}$ and treated with sodium hexamethyldisilazane $(1 \mathrm{M}$ in THF, $0.2 \mathrm{~mL}, 0.2 \mathrm{mmol}$, 2 equiv.). After 10 minutes, this solution was transferred by syringe to a flask containing the solution of either $p$-nitrobenzenesulfonyl chloride $4 \mathbf{h}$ ( $0.0442 \mathrm{~g}, 0.2 \mathrm{mmol}, 2$ equiv.) or 3,5-bis(trifluoromethyl)benzenesulfonyl chloride $4 \mathbf{i}(0.0623 \mathrm{~g}, 0.2 \mathrm{mmol}, 2$ equiv.) in $1.0 \mathrm{~mL}$ of THF that had been pre-cooled to $-30{ }^{\circ} \mathrm{C}$. The flask that contained the donor was then rinsed with an additional $0.5 \mathrm{~mL}$ of THF, and this rinse was then added to the donor and sulfonyl chloride reaction mixture. After this mixture has stirred for two hours at $-30{ }^{\circ} \mathrm{C}$, it was treated with a freshly prepared solution of the alkoxide acceptor (prepared by treating a solution of acceptor $2(0.0464 \mathrm{~g}, 0.1 \mathrm{mmol}, 1$ equiv.) in $0.5 \mathrm{~mL}$ of THF at $-30{ }^{\circ} \mathrm{C}$ with sodium hexamethyldisilazane $(0.1 \mathrm{~mL}, 0.1 \mathrm{mmol}, 1$ equiv.) and stirring for 10 minutes.). The flask that had contained the acceptor was rinsed with 0.5 $\mathrm{mL}$ of THF, and this rinse was then added to the glycosylation reaction. After 5 hours, the reaction was quenched with $0.05 \mathrm{~mL}$ of saturated aqueous ammonium chloride $\left(\mathrm{NH}_{4} \mathrm{Cl}\right)$, diluted with water, and extracted with diethyl ether $(4 \times 10 \mathrm{~mL})$. The combined organic phase was washed with brine $(20 \mathrm{~mL})$ and then dried $\left(\mathrm{Na}_{2} \mathrm{SO}_{4}\right)$, filtered, and concentrated under reduced pressure. The crude product was purified by silica gel flash column chromatography (20\% ethyl acetate in hexane) to afford disaccharide 21 as a single $\beta$-isomer $(0.0675 \mathrm{~g}, 0.072 \mathrm{mmol}, 72 \%$ yield) when $\mathbf{4 h}$ was used as the promoter or $(0.0781 \mathrm{~g}, 0.083 \mathrm{mmol}, 83 \%$ yield $)$ when $4 \mathbf{i}$ was used as the promoter.

${ }^{1} \mathbf{H}$ NMR $\left(500 \mathrm{MHz}, \mathrm{CDCl}_{3}\right) \delta 7.50-7.01(\mathrm{~m}, 30 \mathrm{H}), 4.99-4.89(\mathrm{~m}, 3 \mathrm{H}), 4.84-4.75$ $(\mathrm{m}, 3 \mathrm{H}), 4.73-4.71(\mathrm{~m}, 2 \mathrm{H}), 4.69-4.55(\mathrm{~m}, 3 \mathrm{H}), 4.52-7.01(\mathrm{~m}, 3 \mathrm{H}), 4.37(\mathrm{~d}, J=7.6$ $\mathrm{Hz}, 1 \mathrm{H}), 4.17$ (dd, $J=10.7,1.7 \mathrm{~Hz}, 1 \mathrm{H}), 3.99$ (t, $J=9.3 \mathrm{~Hz}, 1 \mathrm{H}), 3.82$ (dd, $J=10.0$, 
$2.7 \mathrm{~Hz}, 1 \mathrm{H}), 3.69$ (dd, $J=10.8,4.6 \mathrm{~Hz}, 1 \mathrm{H}), 3.62-3.45(\mathrm{~m}, 7 \mathrm{H}), 3.33(\mathrm{~s}, 3 \mathrm{H}), 1.82(\mathrm{~s}$, $3 \mathrm{H})$.

${ }^{13}$ C NMR $\left(125 \mathrm{MHz}, \mathrm{CDCl}_{3}\right) \delta 169.8,138.9,138.4,138.4,138.2,138.2,138.0,128.5$, $128.4,128.2$, 128.0, 127.9, 127.8, 127.8, 127.7, 127.6, 127.6, 127.6, 103.7, 98.1, 82.0, $81.9,81.8,79.9,78.0,75.7,75.1,75.0,74.9,73.6,73.5,73.4,71.2,70.0,69.8,68.7$, 55.3, 20.8. The ${ }^{1} \mathrm{H}$ NMR and ${ }^{13} \mathrm{C}$ NMR spectra coincide with the previous report. ${ }^{[2]}$

Methyl 6-O-(4-O-triisopropylsilyl-2,3,6-tri- $O$-benzyl- $\beta$-D-glucopyranosyl)-2,3,4tri-O-benzyl- $\alpha$-D-glucopyranoside 22

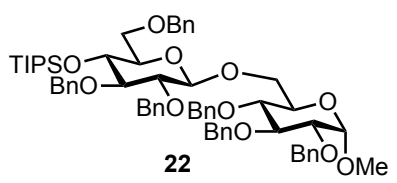

A solution of donor $9(0.1212 \mathrm{~g}, 0.2 \mathrm{mmol}, 2$ equiv. $)$ in $1.0 \mathrm{~mL}$ of THF was cooled to $30{ }^{\circ} \mathrm{C}$ and treated with sodium hexamethyldisilazane ( $1 \mathrm{M}$ in THF, $0.2 \mathrm{~mL}, 0.2 \mathrm{mmol}$, 2 equiv.). After 10 minutes, this solution was transferred by syringe to a flask containing the solution of either $p$-nitrobenzenesulfonyl chloride $4 \mathbf{h}(0.0442 \mathrm{~g}, 0.2 \mathrm{mmol}, 2$ equiv. $)$ or 3,5-bis(trifluoromethyl)benzenesulfonyl chloride $4 \mathbf{i}$ ( $0.0623 \mathrm{~g}, 0.2 \mathrm{mmol}, 2$ equiv.) in $1.0 \mathrm{~mL}$ of THF that had been pre-cooled to $-30{ }^{\circ} \mathrm{C}$. The flask that contained the donor was then rinsed with an additional $0.5 \mathrm{~mL}$ of THF, and this rinse was then added to the donor and sulfonyl chloride reaction mixture. After this mixture has stirred for two hours at $-30{ }^{\circ} \mathrm{C}$, it was treated with a freshly prepared solution of the alkoxide acceptor (prepared by treating a solution of acceptor $2(0.0464 \mathrm{~g}, 0.1 \mathrm{mmol}, 1$ equiv.) in $0.5 \mathrm{~mL}$ of THF at $-30{ }^{\circ} \mathrm{C}$ with sodium hexamethyldisilazane $(0.1 \mathrm{~mL}, 0.1 \mathrm{mmol}, 1$ equiv. $)$ and stirring for 10 minutes.). The flask that had contained the acceptor was rinsed with 0.5 $\mathrm{mL}$ of THF, and this rinse was then added to the glycosylation reaction. After 18 hours, the reaction was quenched with $0.05 \mathrm{~mL}$ of saturated aqueous ammonium chloride $\left(\mathrm{NH}_{4} \mathrm{Cl}\right)$, diluted with water, and extracted with diethyl ether $(4 \times 10 \mathrm{~mL})$. The combined organic phase was washed with brine $(20 \mathrm{~mL})$ and then dried $\left(\mathrm{Na}_{2} \mathrm{SO}_{4}\right)$, filtered, and concentrated under reduced pressure. The crude product was purified by silica gel flash column chromatography (12\% ethyl acetate in hexane) to afford disaccharide 22 as a single $\beta$-isomer $(0.0550 \mathrm{~g}, 0.052 \mathrm{mmol}, 52 \%$ yield) when $\mathbf{4 h}$ was used as the promoter or $(0.0602 \mathrm{~g}, 0.057 \mathrm{mmol}, 57 \%$ yield $)$ when $4 \mathbf{i}$ was used as the promoter.

$[\alpha]_{\mathbf{D}}{ }^{22}=+37.9^{\circ}\left(c\right.$ 2.0, $\left.\mathrm{CH}_{2} \mathrm{Cl}_{2}\right) ;$ 
${ }^{1} \mathbf{H}$ NMR (500 MHz, $\left.\mathrm{CDCl}_{3}\right) \delta 7.38-7.09(\mathrm{~m}, 30 \mathrm{H}), 5.07$ (d, $\left.J=11.5 \mathrm{~Hz}, 1 \mathrm{H}\right), 4.98-$ $4.94(\mathrm{~m}, 2 \mathrm{H}), 4.81-4.73(\mathrm{~m}, 2 \mathrm{H}), 4.70(\mathrm{~d}, J=11.1 \mathrm{~Hz}, 1 \mathrm{H}), 4.64-4.61(\mathrm{~m}, 2 \mathrm{H}), 4.60$ $-4.52(\mathrm{~m}, 3 \mathrm{H}), 4.52-4.46(\mathrm{~m}, 2 \mathrm{H}), 4.43(\mathrm{~d}, J=7.5 \mathrm{~Hz}, 1 \mathrm{H}), 4.20$ (dd, $J=10.8,1.8$ $\mathrm{Hz}, 1 \mathrm{H}), 3.97$ (t, $J=9.3 \mathrm{~Hz}, 1 \mathrm{H}), 3.82$ (dd, $J=10.0,2.8 \mathrm{~Hz}, 1 \mathrm{H}), 3.79-3.75(\mathrm{~m}, 1 \mathrm{H})$, $3.75-3.65(\mathrm{~m}, 2 \mathrm{H}), 3.60(\mathrm{dd}, J=10.5,6.5 \mathrm{~Hz}, 1 \mathrm{H}), 3.53-3.39(\mathrm{~m}, 5 \mathrm{H}), 3.30(\mathrm{~s}, 3 \mathrm{H})$, $0.96-0.90(\mathrm{~m}, 21 \mathrm{H})$.

${ }^{13}$ C NMR (125 MHz, $\left.\mathrm{CDCl}_{3}\right) \delta 139.1,138.9,138.4,138.3,138.2,128.5,128.4,128.3$, 128.3, 128.3, 128.1, 128.0, 128.0, 127.9, 127.7, 127.7, 127.7, 127.6, 127.5, 127.4, 127.0, $126.8,103.4,98.1,84.8,82.8,82.0,79.9,78.1,76.9,75.7,74.9,74.2,74.2,73.5,73.4$, $71.5,70.1,69.9,68.3,55.2,18.3,18.1,13.3$.

LRMS (ESI) $\mathbf{m} / \mathbf{z}$ : calculated for $\mathrm{C}_{64} \mathrm{H}_{80} \mathrm{NaO}_{11} \mathrm{Si}(\mathrm{M}+\mathrm{Na})=1075.54$; found 1075.63; HRMS (ESI) $\mathbf{m} / \mathbf{z}$ : calculated for $\mathrm{C}_{64} \mathrm{H}_{80} \mathrm{NaO}_{11} \mathrm{Si}(\mathrm{M}+\mathrm{Na})=1075.5368$; found 1075.5378 .

Methyl 2-O-benzyl-3- $O$-(2,3,4,6-tetra- $O$-benzyl- $\beta$-D-glucopyranosyl)-(1 $\rightarrow 3)-4,6-$ $O$-benzylidene- $\alpha$-D-glucopyranoside 23

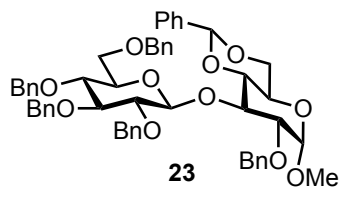

A solution of donor 1 ( $0.3242 \mathrm{~g}, 0.6 \mathrm{mmol}, 3$ equiv.) in $3.0 \mathrm{~mL}$ of THF was cooled to $30{ }^{\circ} \mathrm{C}$ or $-40{ }^{\circ} \mathrm{C}$ and treated with sodium hexamethyldisilazane $(1 \mathrm{M}$ in THF, $0.6 \mathrm{~mL}$, 0.6 mmol, 3 equiv.). After 10 minutes, this solution was transferred by syringe to a flask containing the solution of either $p$-nitrobenzenesulfonyl chloride $4 \mathbf{h}(0.1326 \mathrm{~g}, 0.6$ mmol, 3 equiv., $\left.-30{ }^{\circ} \mathrm{C}\right)$ or 3,5-bis(trifluoromethyl)benzenesulfonyl chloride $4 \mathbf{i}(0.1871$ $\mathrm{g}, 0.6 \mathrm{mmol}, 3$ equiv., $-40^{\circ} \mathrm{C}$ ) in $3.0 \mathrm{~mL}$ of $\mathrm{THF}$ that had been pre-cooled to corresponding temperature. The flask that contained the donor was then rinsed with an additional $1.5 \mathrm{~mL}$ of THF, and this rinse was then added to the donor and sulfonyl chloride reaction mixture. After this mixture has stirred for two hours, it was treated with a freshly prepared solution of the alkoxide acceptor (prepared by treating a solution of acceptor $12\left(0.0744 \mathrm{~g}, 0.2 \mathrm{mmol}, 1\right.$ equiv.) in $2.0 \mathrm{~mL}$ of $\mathrm{THF}$ at $-30{ }^{\circ} \mathrm{C}$ or $-40{ }^{\circ} \mathrm{C}$ with potassium hexamethyldisilazane $(0.2 \mathrm{~mL}, 0.2 \mathrm{mmol}, 1$ equiv.) and stirring for 10 minutes.). The flask that had contained the acceptor was rinsed with $1.0 \mathrm{~mL}$ of THF, and this rinse was then added to the glycosylation reaction. After 18 hours, the reaction was quenched with $0.15 \mathrm{~mL}$ of saturated aqueous ammonium chloride $\left(\mathrm{NH}_{4} \mathrm{Cl}\right)$, diluted with water, and extracted with diethyl ether $(4 \times 20 \mathrm{~mL})$. The combined organic phase was washed with brine $(40 \mathrm{~mL})$ and then dried $\left(\mathrm{Na}_{2} \mathrm{SO}_{4}\right)$, filtered, and concentrated under reduced pressure. The crude product was purified by silica gel flash column 
chromatography ( $15 \%$ ethyl acetate in hexane) to afford disaccharide $23(0.1073 \mathrm{~g}, 0.12$ mmol, $60 \%$ yield, $\beta: \alpha 14: 1)$ when $4 \mathrm{~h}$ was used as the promoter or $(0.1038 \mathrm{~g}, 0.12 \mathrm{mmol}$, $58 \%$ yield, $\beta: \alpha$ 14:1) when $4 \mathbf{i}$ was used as the promoter. The selectivity was determined by ${ }^{1} \mathrm{H}$ NMR integration of the anomeric signals of purified 23 . The $\beta$ and $\alpha$ products did not separate significantly on silica gel, and care was taken to isolate the entire chromatographic band.

\section{$\beta$-isomer}

${ }^{1} \mathbf{H}$ NMR (500 MHz, $\left.\mathrm{CDCl}_{3}\right) \delta 7.44-7.13(\mathrm{~m}, 30 \mathrm{H}), 5.47(\mathrm{~s}, 1 \mathrm{H}), 5.06(\mathrm{~d}, J=11.2 \mathrm{~Hz}$, $1 \mathrm{H}), 4.90(\mathrm{dd}, J=11.5,9.5 \mathrm{~Hz}, 2 \mathrm{H}), 4.81-4.68(\mathrm{~m}, 4 \mathrm{H}), 4.53(\mathrm{~d}, J=10.7 \mathrm{~Hz}, 1 \mathrm{H})$, $4.47-4.45(\mathrm{~m}, 4 \mathrm{H}), 4.36(\mathrm{t}, J=9.1 \mathrm{~Hz}, 1 \mathrm{H}), 4.21(\mathrm{dd}, J=4.7,4.7 \mathrm{~Hz}, 1 \mathrm{H}), 3.82(\mathrm{td}, J$ $=9.9,4.7 \mathrm{~Hz}, 1 \mathrm{H}), 3.71-3.55(\mathrm{~m}, 7 \mathrm{H}), 3.50(\mathrm{t}, J=8.2 \mathrm{~Hz}, 1 \mathrm{H}), 3.35(\mathrm{~s}, 3 \mathrm{H}), 3.26-$ $3.22(\mathrm{~m}, 1 \mathrm{H})$.

${ }^{13}$ C NMR (125 MHz, $\left.\mathrm{CDCl}_{3}\right) \delta 139.0,138.9,138.6,138.4,138.2,137.5,129.0,128.5$, $128.5,128.5,128.4,128.4,128.2,128.2,128.1,128.0,127.9,127.8,127.6,127.6,126.3$, 102.6, 101.6, 98.8, 85.1, 83.1, 80.6, 80.5, 78.1, 76.0, 75.7, 75.1, 75.0, 74.9, 73.9, 73.7, 69.2, 68.8, 62.3, 55.54. The ${ }^{1} \mathrm{H}$ NMR and ${ }^{13} \mathrm{C}$ NMR spectra coincide with the previous report ${ }^{[14]}$.

\section{$\alpha$-isomer}

${ }^{1} \mathbf{H}$ NMR $\left(500 \mathrm{MHz}, \mathrm{CDCl}_{3}\right) \delta 7.47-7.10(\mathrm{~m}, 28 \mathrm{H}), 6.96(\mathrm{~d}, J=7.3 \mathrm{~Hz}, 2 \mathrm{H}), 5.62(\mathrm{~d}$, $J=3.5 \mathrm{~Hz}, 1 \mathrm{H}), 5.50(\mathrm{~s}, 1 \mathrm{H}), 5.03(\mathrm{~d}, J=10.8 \mathrm{~Hz}, 1 \mathrm{H}), 4.84(\mathrm{~d}, J=4.7 \mathrm{~Hz}, 1 \mathrm{H}), 4.82$ $(\mathrm{d}, J=5.0 \mathrm{~Hz}, 1 \mathrm{H}), 4.74(\mathrm{~d}, J=3.7 \mathrm{~Hz}, 1 \mathrm{H}), 4.69(\mathrm{~d}, J=11.2 \mathrm{~Hz}, 1 \mathrm{H}), 4.65-4.56(\mathrm{~m}$, $3 \mathrm{H}), 4.42-4.39(\mathrm{~m}, 2 \mathrm{H}), 4.37-4.31(\mathrm{~m}, 2 \mathrm{H}), 4.28(\mathrm{dd}, J=10.2,4.8 \mathrm{~Hz}, 1 \mathrm{H}), 4.23$ (d, $J=10.1 \mathrm{~Hz}, 1 \mathrm{H}), 4.00(\mathrm{t}, J=9.3 \mathrm{~Hz}, 1 \mathrm{H}), 3.91(\mathrm{td}, J=9.9,4.8 \mathrm{~Hz}, 1 \mathrm{H}), 1 \mathrm{H}), 3.82(\mathrm{t}, J$ $=9.4 \mathrm{~Hz}, 1 \mathrm{H}), 3.76-3.67(\mathrm{~m}, 3 \mathrm{H}), 3.56-3.50(\mathrm{~m}, 3 \mathrm{H}), 3.45(\mathrm{~s}, 3 \mathrm{H})$.

${ }^{13} \mathbf{C}$ NMR $\left(126 \mathrm{MHz}, \mathrm{CDCl}_{3}\right) \delta 139.1,139.0,138.2,138.0,137.6,137.3,129.5,128.8$, 128.6, 128.6, 128.4, 128.4, 128.3, 128.3, 128.3, 128.1, 128.0, 127.7, 127.7, 127.5, 127.5, $127.4,126.6,102.3,98.7,96.3,83.1,81.8,78.9,78.2,77.7,75.7,74.9,73.6,73.5,72.9$, $71.3,70.0,69.4,68.3,61.9,55.5$. The ${ }^{1} \mathrm{H}$ NMR and ${ }^{13} \mathrm{C}$ NMR spectra coincide with the previous report. ${ }^{[14]}$

Methyl 2-O-benzyl-3-O-(2,3,4,6-tetra- $O$-benzyl- $\beta$-D-glucopyranosyl)-(1 $\rightarrow 3)-4,6-$ $\boldsymbol{O}$-benzylidene- $\boldsymbol{\beta}$-D-glucopyranoside 24

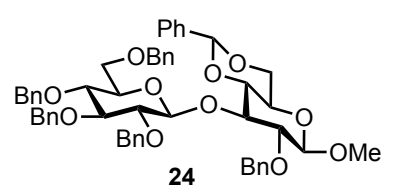

A solution of donor $1(0.2160 \mathrm{~g}, 0.4 \mathrm{mmol}, 3$ equiv. $)$ in $2.0 \mathrm{~mL}$ of THF was cooled to $30{ }^{\circ} \mathrm{C}$ and treated with sodium hexamethyldisilazane ( $1 \mathrm{M}$ in THF, $0.4 \mathrm{~mL}, 0.4 \mathrm{mmol}$, 3 equiv.). After 10 minutes, this solution was transferred by syringe to a flask containing 
the solution of either $p$-nitrobenzenesulfonyl chloride $\mathbf{4 h}(0.0884 \mathrm{~g}, 0.4 \mathrm{mmol}, 3$ equiv.) or 3,5-bis(trifluoromethyl)benzenesulfonyl chloride $4 \mathbf{i}$ ( $0.1246 \mathrm{~g}, 0.4 \mathrm{mmol}, 3$ equiv.) in $2.0 \mathrm{~mL}$ of THF that had been pre-cooled to $-30^{\circ} \mathrm{C}$. The flask that contained the donor was then rinsed with an additional $1.0 \mathrm{~mL}$ of THF, and this rinse was then added to the donor and sulfonyl chloride reaction mixture. After this mixture has stirred for two hours at $-30{ }^{\circ} \mathrm{C}$, it was treated with a freshly prepared solution of the alkoxide acceptor (prepared by treating a solution of acceptor 13 (0.0496 g, $0.133 \mathrm{mmol}, 1$ equiv.) in 1.4 $\mathrm{mL}$ of THF at $-30{ }^{\circ} \mathrm{C}$ with potassium hexamethyldisilazane $(0.133 \mathrm{~mL}, 0.133 \mathrm{mmol}, 1$ equiv.) and stirring for 10 minutes.). The flask that had contained the acceptor was rinsed with $0.6 \mathrm{~mL}$ of THF, and this rinse was then added to the glycosylation reaction. After 19 hours, the reaction was quenched with $0.1 \mathrm{~mL}$ of saturated aqueous ammonium chloride $\left(\mathrm{NH}_{4} \mathrm{Cl}\right)$, diluted with water, and extracted with diethyl ether $(4 \times 15 \mathrm{~mL})$. The combined organic phase was washed with brine $(30 \mathrm{~mL})$ and then dried $\left(\mathrm{Na}_{2} \mathrm{SO}_{4}\right)$, filtered, and concentrated under reduced pressure. The crude product was purified by silica gel flash column chromatography (12.5\% ethyl acetate in hexane) to afford disaccharide 24 as an amorphous solid (0.0654 g, $0.073 \mathrm{mmol}, 55 \%$ yield, $\beta: \alpha 11: 1)$ when $4 \mathrm{~h}$ was used as the promoter or $(0.0749 \mathrm{~g}, 0.084 \mathrm{mmol}, 63 \%$ yield, $\beta: \alpha 10: 1)$ when $4 \mathbf{i}$ was used as the promoter. The selectivity was determined by ${ }^{1} \mathrm{H}$ NMR integration of the anomeric signals of purified $\mathbf{2 4}$.

\section{$\beta$-isomer}

$[\boldsymbol{\alpha}]_{\mathbf{D}}{ }^{\mathbf{2 2}}=+2.2^{\circ}\left(c 1.0, \mathrm{CH}_{2} \mathrm{Cl}_{2}\right)$;

${ }^{1} \mathbf{H}$ NMR $\left(500 \mathrm{MHz}, \mathrm{CDCl}_{3}\right) \delta 7.50-7.01(\mathrm{~m}, 30 \mathrm{H}), 5.47(\mathrm{~s}, 1 \mathrm{H}), 5.00(\mathrm{~d}, J=11.1 \mathrm{~Hz}$, 1H), $4.90(\mathrm{~d}, J=11.0 \mathrm{~Hz}, 1 \mathrm{H}), 4.87(\mathrm{~d}, J=7.8 \mathrm{~Hz}, 1 \mathrm{H}), 4.81-4.73(\mathrm{~m}, 3 \mathrm{H}), 4.71$ (d, $J=11.1 \mathrm{~Hz}, 1 \mathrm{H}), 4.64(\mathrm{~d}, J=10.4 \mathrm{~Hz}, 1 \mathrm{H}), 4.51(\mathrm{~d}, J=10.8 \mathrm{~Hz}, 1 \mathrm{H}), 4.47(\mathrm{~s}, 2 \mathrm{H})$, $4.42(\mathrm{~d}, J=7.6 \mathrm{~Hz}, 1 \mathrm{H}), 4.32(\mathrm{dd}, J=10.4,4.8 \mathrm{~Hz}, 1 \mathrm{H}), 4.10(\mathrm{t}, J=8.9 \mathrm{~Hz}, 1 \mathrm{H}), 3.78$ $-3.69(\mathrm{~m}, 2 \mathrm{H}), 3.61-3.53(\mathrm{~m}, 8 \mathrm{H}), 3.51-3.46(\mathrm{~m}, 1 \mathrm{H}), 3.40(\mathrm{td}, \mathrm{J}=9.8,4.9 \mathrm{~Hz}, 1 \mathrm{H})$, $3.27-3.20(\mathrm{~m}, 1 \mathrm{H})$.

${ }^{13}$ C NMR $\left(125 \mathrm{MHz}, \mathrm{CDCl}_{3}\right) \delta 138.8,138.7,138.5,138.4,138.3,137.5,129.0,128.5$, $128.5,128.4,128.4,128.3,128.3,128.2,128.1,128.1,128.0,128.0,127.8,127.7,127.7$, $127.6,127.5,126.3,105.2,102.6,101.4,85.0,82.9,79.7,78.7,78.1,75.7,75.1,75.1$, 75.0, 74.9, 73.7, 69.1, 68.90, 66.3, 57.5;

LRMS (ESI) m/z: calculated for $\mathrm{C}_{55} \mathrm{H}_{58} \mathrm{NaO}_{11}(\mathrm{M}+\mathrm{Na})=917.39$; found 917.45; HRMS (ESI) m/z: calculated for $\mathrm{C}_{55} \mathrm{H}_{58} \mathrm{NaO}_{11}(\mathrm{M}+\mathrm{Na})=917.3877$; found 917.3912.

$\alpha$-isomer

$[\alpha]_{\mathbf{D}}{ }^{22}=+30.7^{\circ}\left(c 0.6, \mathrm{CH}_{2} \mathrm{Cl}_{2}\right)$;

${ }^{1} \mathbf{H}$ NMR $\left(500 \mathrm{MHz}, \mathrm{CDCl}_{3}\right) \delta 7.46-7.00(\mathrm{~m}, 28 \mathrm{H}), 6.92(\mathrm{~d}, J=7.3 \mathrm{~Hz}, 2 \mathrm{H}), 5.58(\mathrm{~d}$, $J=3.6 \mathrm{~Hz}, 1 \mathrm{H}), 5.46(\mathrm{~s}, 1 \mathrm{H}), 5.01$ (d, $J=10.8 \mathrm{~Hz}, 1 \mathrm{H}), 4.87(\mathrm{~d}, J=10.0 \mathrm{~Hz}, 1 \mathrm{H}), 4.83$ 
- $4.79(\mathrm{~m}, 2 \mathrm{H}), 4.60(\mathrm{~d}, J=10.0 \mathrm{~Hz}, 1 \mathrm{H}), 4.56(\mathrm{~d}, J=12.3 \mathrm{~Hz}, 1 \mathrm{H}), 4.51(\mathrm{~d}, J=12.1$ $\mathrm{Hz}, 1 \mathrm{H}), 4.46(\mathrm{~d}, J=7.7 \mathrm{~Hz}, 1 \mathrm{H}), 4.38-4.30(\mathrm{~m}, 3 \mathrm{H}), 4.21(\mathrm{~d}, J=12.1 \mathrm{~Hz}, 1 \mathrm{H}), 4.15$ - 4.06 (m, 2H), 3.97 (t, $J=9.4 \mathrm{~Hz}, 1 \mathrm{H}), 3.85-3.76(\mathrm{~m}, 2 \mathrm{H}), 3.62(\mathrm{~s}, 3 \mathrm{H}), 3.53-3.42$ (m, 3H), $3.29(\mathrm{dd}, J=10.8,2.4 \mathrm{~Hz}, 1 \mathrm{H}), 3.24(\mathrm{dd}, J=10.8,1.8 \mathrm{~Hz}, 1 \mathrm{H})$.

${ }^{13}$ C NMR (126 MHz, $\left.\mathrm{CDCl}_{3}\right) \delta 139.2,139.0,138.1,138.1,137.9,137.8,137.1,129.6$, $129.1,128.6,128.4,128.4,128.4,128.3,128.2$, 128.0, 127.9, 127.9, 127.7, 127.6, 127.6, $127.6,127.5,126.5,105.8,102.2,96.2,82.4,81.9,80.3,78.8,77.6,75.7,75.5,75.2$, 75.1, 73.5, 71.3, 69.8, 69.1, 68.0, 65.9, 57.7;

LRMS (ESI) m/z: calculated for $\mathrm{C}_{55} \mathrm{H}_{58} \mathrm{NaO}_{11}(\mathrm{M}+\mathrm{Na})=917.39$; found 917.45;

HRMS (ESI) $\mathbf{m} / \mathbf{z}$ : calculated for $\mathrm{C}_{55} \mathrm{H}_{58} \mathrm{NaO}_{11}(\mathrm{M}+\mathrm{Na})=917.3877$; found 917.3895.

Methyl 2,4,6-tri-O-benzyl-3-O-(2,3,4,6-tetra-O-benzyl- $\beta$-D-glucopyranosyl)- $\alpha$-Dglucopyranoside 25

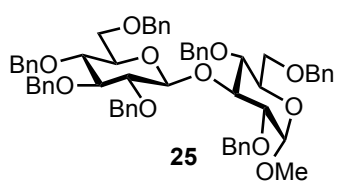

A solution of donor $1(0.2160 \mathrm{~g}, 0.4 \mathrm{mmol}, 3$ equiv. $)$ in $2.0 \mathrm{~mL}$ of THF was cooled to $15{ }^{\circ} \mathrm{C}$ or $-40{ }^{\circ} \mathrm{C}$ and treated with sodium hexamethyldisilazane $(1 \mathrm{M}$ in THF, $0.4 \mathrm{~mL}$, $0.4 \mathrm{mmol}, 3$ equiv.). After 10 minutes, this solution was transferred by syringe to a flask containing the solution of either $p$-nitrobenzenesulfonyl chloride 4 h $(0.0884 \mathrm{~g}, 0.4$ mmol, 3 equiv., $\left.-15^{\circ} \mathrm{C}\right)$ or 3,5-bis(trifluoromethyl)benzenesulfonyl chloride $4 \mathbf{i}(0.1246$ g, $0.4 \mathrm{mmol}, 3$ equiv., $-40{ }^{\circ} \mathrm{C}$ ) in $2.0 \mathrm{~mL}$ of THF that had been pre-cooled to corresponding temperature. The flask that contained the donor was then rinsed with an additional $1.0 \mathrm{~mL}$ of THF, and this rinse was then added to the donor and sulfonyl chloride reaction mixture. After this mixture has stirred for two hours, it was treated with a freshly prepared solution of the alkoxide acceptor (prepared by treating a solution of acceptor 14 (0.0617 g, $0.133 \mathrm{mmol}, 1$ equiv.) in $1.4 \mathrm{~mL}$ of $\mathrm{THF}$ at $-15{ }^{\circ} \mathrm{C}$ or $-40{ }^{\circ} \mathrm{C}$ with potassium hexamethyldisilazane $(0.133 \mathrm{~mL}, 0.133 \mathrm{mmol}, 1$ equiv. $)$ and stirring for 10 minutes.). The flask that had contained the acceptor was rinsed with $0.6 \mathrm{~mL}$ of THF, and this rinse was then added to the glycosylation reaction. After 24 hours, the reaction was quenched with $0.1 \mathrm{~mL}$ of saturated, aqueous ammonium chloride $\left(\mathrm{NH}_{4} \mathrm{Cl}\right)$, diluted with water, and extracted with diethyl ether $(4 \times 15 \mathrm{~mL})$. The combined organic phase was washed with brine $(30 \mathrm{~mL})$ and then dried $\left(\mathrm{Na}_{2} \mathrm{SO}_{4}\right)$, filtered, and concentrated under reduced pressure. The crude product was purified by silica gel flash column chromatography (15\% ethyl acetate in hexane) to afford disaccharide $25(0.0630 \mathrm{~g}$, $0.064 \mathrm{mmol}, 48 \%$ yield, $\beta: \alpha$ 12:1) when $4 \mathrm{~h}$ was used as the promoter or $(0.0708 \mathrm{~g}$, $0.072 \mathrm{mmol}, 54 \%$ yield, $\beta: \alpha$ 12:1) when $\mathbf{4 i}$ was used as the promoter. The selectivity was determined by ${ }^{1} \mathrm{H}$ NMR integration of the anomeric signals of purified $\mathbf{2 5}$. The $\beta$ 
and $\alpha$ products did not separate significantly on silica gel, and care was taken to isolate the entire chromatographic band.

\section{$\beta$-isomer}

${ }^{1} \mathbf{H}$ NMR $\left(500 \mathrm{MHz}, \mathrm{CDCl}_{3}\right) \delta 7.45-6.99(\mathrm{~m}, 35 \mathrm{H}), 5.10-5.03(\mathrm{~m}, 3 \mathrm{H}), 5.00(\mathrm{~d}, J=$ $10.8 \mathrm{~Hz}, 1 \mathrm{H}), 4.90-4.85(\mathrm{~m}, 2 \mathrm{H}), 4.82(\mathrm{~d}, J=10.6 \mathrm{~Hz}, 1 \mathrm{H}), 4.65(\mathrm{~d}, J=11.6 \mathrm{~Hz}, 1 \mathrm{H})$, $4.61-4.58(\mathrm{~m}, 2 \mathrm{H}), 4.54-4.48(\mathrm{~m}, 4 \mathrm{H}), 4.46-4.43(\mathrm{~m}, 2 \mathrm{H}), 4.40-4.36(\mathrm{~m}, 2 \mathrm{H})$, $3.79-3.70(\mathrm{~m}, 5 \mathrm{H}), 3.69-4.65(\mathrm{~m}, 1 \mathrm{H}), 3.61-3.57(\mathrm{~m}, 2 \mathrm{H}), 3.52(\mathrm{dd}, J=9.5,3.5$ $\mathrm{Hz}, 1 \mathrm{H}), 3.47(\mathrm{t}, J=8.5 \mathrm{~Hz}, 1 \mathrm{H}), 3.42-3.41(\mathrm{~m}, 1 \mathrm{H}), 3.31(\mathrm{~s}, 3 \mathrm{H})$.

${ }^{13}$ C NMR $\left(125 \mathrm{MHz}, \mathrm{CDCl}_{3}\right) \delta 139.0,138.9,138.8,138.77,138.4,138.4,138.2,138.1$, $128.5,128.5,128.3,128.3,128.2,128.1,128.0,128.0,127.8,127.7,127.7,127.5,127.4$, $102.7,97.9,85.2,83.4,81.4,78.4,77.7,76.2,75.9,75.2,75.1,74.9,74.8,73.7,73.5$, 69.7, 69.1, 68.8, 55.2. The ${ }^{1} \mathrm{H}$ NMR and ${ }^{13} \mathrm{C}$ NMR spectra coincide with the previous report. ${ }^{[15]}$

\section{$\alpha$-isomer}

${ }^{1} \mathbf{H}$ NMR (500 MHz, $\left.\mathrm{CDCl}_{3}\right) \delta 7.38-6.91(\mathrm{~m}, 35 \mathrm{H}), 5.59(\mathrm{~d}, J=3.5 \mathrm{~Hz}, 1 \mathrm{H}), 4.94(\mathrm{~d}$, $J=11.5 \mathrm{~Hz}, 1 \mathrm{H}), 4.90(\mathrm{~d}, J=10.9 \mathrm{~Hz}, 1 \mathrm{H}), 4.83-4.79(\mathrm{~m}, 2 \mathrm{H}), 4.70-4.65(\mathrm{~m}, 2 \mathrm{H})$, $4.63-4.56(\mathrm{~m}, 5 \mathrm{H}), 4.52(\mathrm{~d}, J=11.4 \mathrm{~Hz}, 1 \mathrm{H}), 4.46(\mathrm{~d}, J=3.2 \mathrm{~Hz}, 1 \mathrm{H}), 4.43(\mathrm{~d}, J=$ $4.3 \mathrm{~Hz}, 1 \mathrm{H}), 4.40-4.29(\mathrm{~m}, 3 \mathrm{H}), 4.25(\mathrm{t}, J=9.0 \mathrm{~Hz}, 1 \mathrm{H}), 4.05(\mathrm{t}, J=9.4 \mathrm{~Hz}, 1 \mathrm{H}), 3.80$ $-3.74(\mathrm{~m}, 2 \mathrm{H}), 3.73-3.64(\mathrm{~m}, 3 \mathrm{H}), 3.63-3.48(\mathrm{~m}, 6 \mathrm{H}), 3.31(\mathrm{~s}, 3 \mathrm{H})$.

${ }^{13}$ C NMR (125 MHz, $\left.\mathrm{CDCl}_{3}\right) \delta 139.0,138.9,138.5,138.2,138.1,138.1,128.9,128.5$, $128.5,128.4,128.4,128.3,128.2,128.1,128.0,128.0,127.9,127.8,127.7,127.6,127.6$, $127.4,127.1,97.7,97.5,82.4,79.9,79.0,78.8,78.3,75.6,75.0,73.7,73.7,73.6,73.6$, 73.4, 70.4, 69.7, 68.7, 68.6, 55.2. The ${ }^{1} \mathrm{H}$ NMR and ${ }^{13} \mathrm{C}$ NMR spectra coincide with the previous report. ${ }^{[15]}$

Methyl 3-O-benzyl-2-O-(2,3,4,6-tetra- $O$-benzyl- $\beta$-D-glucopyranosyl)-(1 $\rightarrow 2)-4,6-$ $O$-benzylidene- $\alpha$-D-glucopyranoside 26

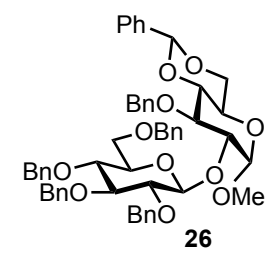

A solution of donor 1 ( $0.2160 \mathrm{~g}, 0.4 \mathrm{mmol}, 3$ equiv.) in $2.0 \mathrm{~mL}$ of THF was cooled to $15{ }^{\circ} \mathrm{C}$ and treated with sodium hexamethyldisilazane $(1 \mathrm{M}$ in THF, $0.4 \mathrm{~mL}, 0.4 \mathrm{mmol}$, 3 equiv.). After 10 minutes, this solution was transferred by syringe to a flask containing the solution of either $p$-nitrobenzenesulfonyl chloride $4 \mathbf{h}(0.0884 \mathrm{~g}, 0.4 \mathrm{mmol}, 3$ equiv. $)$ or 3,5-bis(trifluoromethyl)benzenesulfonyl chloride $4 \mathbf{i}$ ( $0.1246 \mathrm{~g}, 0.4 \mathrm{mmol}, 3$ equiv.) in $2.0 \mathrm{~mL}$ of THF that had been pre-cooled to $-15^{\circ} \mathrm{C}$. The flask that contained the donor 
was then rinsed with an additional $1.0 \mathrm{~mL}$ of THF, and this rinse was then added to the donor and sulfonyl chloride reaction mixture. After this mixture has stirred for two hours, it was treated with a freshly prepared solution of the alkoxide acceptor (prepared by treating a solution of acceptor $15(0.0496 \mathrm{~g}, 0.133 \mathrm{mmol}, 1$ equiv.) in $1.4 \mathrm{~mL}$ of THF at $-15{ }^{\circ} \mathrm{C}$ with sodium hexamethyldisilazane $(0.133 \mathrm{~mL}, 0.133 \mathrm{mmol}, 1$ equiv. $)$ and stirring for 10 minutes.). The flask that had contained the acceptor was rinsed with 0.6 $\mathrm{mL}$ of THF, and this rinse was then added to the glycosylation reaction. After 24 hours, the reaction was quenched with $0.1 \mathrm{~mL}$ of saturated aqueous ammonium chloride $\left(\mathrm{NH}_{4} \mathrm{Cl}\right)$, diluted with water, and extracted with diethyl ether $(4 \times 15 \mathrm{~mL})$. The combined organic phase was washed with brine $(30 \mathrm{~mL})$ and then dried $\left(\mathrm{Na}_{2} \mathrm{SO}_{4}\right)$, filtered, and concentrated under reduced pressure. The crude product was purified by silica gel flash column chromatography (13\% ethyl acetate in hexane) to afford disaccharide 26 as a single $\beta$-isomer ( $0.0535 \mathrm{~g}, 0.060 \mathrm{mmol}, 45 \%$ yield) when $\mathbf{4 h}$ was used as the promoter or ( $0.0499 \mathrm{~g}, 0.056 \mathrm{mmol}, 42 \%$ yield) when $4 \mathbf{i}$ was used as the promoter.

${ }^{1} \mathbf{H}$ NMR $\left(500 \mathrm{MHz}, \mathrm{CDCl}_{3}\right) \delta 7.52-7.05(\mathrm{~m}, 30 \mathrm{H}), 5.56(\mathrm{~s}, 1 \mathrm{H}), 5.04(\mathrm{~d}, J=11.4 \mathrm{~Hz}$, $1 \mathrm{H}), 4.96(\mathrm{~d}, J=3.6 \mathrm{~Hz}, 1 \mathrm{H}), 4.92(\mathrm{~d}, J=10.9 \mathrm{~Hz}, 1 \mathrm{H}), 4.83-4.74(\mathrm{~m}, 5 \mathrm{H}), 4.65(\mathrm{~d}$, $J=10.8 \mathrm{~Hz}, 1 \mathrm{H}), 4.57(\mathrm{~d}, J=12.1 \mathrm{~Hz}, 1 \mathrm{H}), 4.53-4.49(\mathrm{~m}, 2 \mathrm{H}), 4.32(\mathrm{dd}, J=10.2,4.8$ $\mathrm{Hz}, 1 \mathrm{H}), 4.10$ (t, $J=9.3 \mathrm{~Hz}, 1 \mathrm{H}), 3.90$ (td, $J=10.1,5.0 \mathrm{~Hz}, 1 \mathrm{H}), 3.85$ (dd, $J=9.5,3.6$ $\mathrm{Hz}, 1 \mathrm{H}), 3.76(\mathrm{t}, J=10.3 \mathrm{~Hz}, 1 \mathrm{H}), 3.67-3.50(\mathrm{~m}, 6 \mathrm{H}), 3.45-3.38(\mathrm{~m}, 4 \mathrm{H})$.

${ }^{13} \mathbf{C}$ NMR $\left(125 \mathrm{MHz}, \mathrm{CDCl}_{3}\right) \delta 138.8,138.6,138.2,138.2,137.6,129.1,128.5,128.5$, $128.4,128.3,128.3,128.3,128.2,128.2,128.1,127.9,127.8,127.7,127.6,127.5,126.2$, $104.5,101.5,100.6,84.9,82.9,82.1,78.6,78.3,77.9,75.8,75.2,75.2,74.8,74.7,73.6$, 69.4, 69.1, 62.4. The ${ }^{1} \mathrm{H}$ NMR spectra coincide with the previous report. ${ }^{[16]}$

Methyl 2,3,6-O-tribenzyl-4-O-(2,3,4,6-O-tetrabenzyl- $\beta / \alpha-D-g l u c o p y r a n o s y l)-\alpha-D-$ glucopyranoside 27

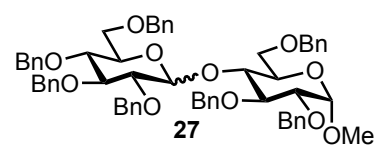

A solution of donor $1(0.2160 \mathrm{~g}, 0.4 \mathrm{mmol}, 3$ equiv. $)$ in $2.0 \mathrm{~mL}$ of THF was cooled to $30{ }^{\circ} \mathrm{C}$ or $-40{ }^{\circ} \mathrm{C}$ and treated with sodium hexamethyldisilazane (1 M in THF, $0.4 \mathrm{~mL}$, 0.4 mmol, 3 equiv.). After 10 minutes, this solution was transferred by syringe to a flask containing the solution of either $p$-nitrobenzenesulfonyl chloride $4 \mathbf{h}(0.0884 \mathrm{~g}, 0.4$ mmol, 3 equiv., $-30^{\circ} \mathrm{C}$ ) or 3,5-bis(trifluoromethyl)benzenesulfonyl chloride $4 \mathbf{i}(0.1246$ g, $0.4 \mathrm{mmol}, 3$ equiv., $-40{ }^{\circ} \mathrm{C}$ ) in $2.0 \mathrm{~mL}$ of THF that had been pre-cooled to corresponding temperature. The flask that contained the donor was then rinsed with an additional $1.0 \mathrm{~mL}$ of THF, and this rinse was then added to the donor and sulfonyl chloride reaction mixture. After this mixture has stirred for two hours, it was treated 
with a freshly prepared solution of the alkoxide acceptor (prepared by treating a solution of acceptor 16 (0.0617 g, $0.133 \mathrm{mmol}, 1$ equiv.) in $1.4 \mathrm{~mL}$ of $\mathrm{THF}$ at $-30{ }^{\circ} \mathrm{C}$ or $-40{ }^{\circ} \mathrm{C}$ with potassium hexamethyldisilazane $(0.133 \mathrm{~mL}, 0.133 \mathrm{mmol}, 1$ equiv.) and stirring for 10 minutes.). The flask that had contained the acceptor was rinsed with $0.6 \mathrm{~mL}$ of THF, and this rinse was then added to the glycosylation reaction. After 23 hours, the reaction was quenched with $0.1 \mathrm{~mL}$ of saturated, aqueous ammonium chloride $\left(\mathrm{NH}_{4} \mathrm{Cl}\right)$, diluted with water, and extracted with diethyl ether $(4 \times 15 \mathrm{~mL})$. The combined organic phase was washed with brine $(30 \mathrm{~mL})$ and then dried $\left(\mathrm{Na}_{2} \mathrm{SO}_{4}\right)$, filtered, and concentrated under reduced pressure. The crude product was purified by silica gel flash column chromatography (15\% ethyl acetate in hexane) to afford disaccharide 27 (0.0499 g, $0.051 \mathrm{mmol}, 38 \%$ yield, $\beta: \alpha$ 16:1) when $4 \mathrm{~h}$ was used as the promoter or $(0.0525 \mathrm{~g}$, $0.053 \mathrm{mmol}, 40 \%$ yield, $\beta: \alpha 6: 1)$ when $4 \mathbf{i}$ was used as the promoter. The selectivity was determined by ${ }^{1} \mathrm{H}$ NMR integration of the anomeric signals of purified $27 \beta$ and $\alpha$ products.

${ }^{1} \mathbf{H}$ NMR $\left(500 \mathrm{MHz}, \mathrm{CDCl}_{3}\right) \delta 7.44-7.01(\mathrm{~m}, 41 \mathrm{H}), 5.69(\mathrm{~d}, J=3.6 \mathrm{~Hz}, 0.2 \mathrm{H}), 5.09$ $(\mathrm{d}, J=11.3 \mathrm{~Hz}, 1 \mathrm{H}), 5.03(\mathrm{~d}, J=11.6 \mathrm{~Hz}, 0.2 \mathrm{H}), 4.89-4.85(\mathrm{~m}, 1 \mathrm{H}), 4.83-4.72(\mathrm{~m}$, $7 \mathrm{H}), 4.70(\mathrm{~d}, J=12.1 \mathrm{~Hz}, 0.2 \mathrm{H}), 4.63-4.51(\mathrm{~m}, 6 \mathrm{H}), 4.49(\mathrm{~d}, J=6.6 \mathrm{~Hz}, 1 \mathrm{H}), 4.46-$ $4.34(\mathrm{~m}, 5 \mathrm{H}), 4.27(\mathrm{~d}, J=12.1 \mathrm{~Hz}, 0.2 \mathrm{H}), 4.09(\mathrm{~d}, J=8.9 \mathrm{~Hz}, 0.2 \mathrm{H}), 4.06(\mathrm{~d}, J=4.4$ $\mathrm{Hz}, 0.2 \mathrm{H}), 4.03(\mathrm{~d}, J=8.9 \mathrm{~Hz}, 0.2 \mathrm{H}), 3.96(\mathrm{t}, J=9.5 \mathrm{~Hz}, 1 \mathrm{H}), 3.90(\mathrm{t}, J=9.3 \mathrm{~Hz}, 0.2 \mathrm{H})$, $3.87-3.80(\mathrm{~m}, 2.6 \mathrm{H}), 3.71(\mathrm{~d}, J=10.8 \mathrm{~Hz}, 1 \mathrm{H}), 3.66(\mathrm{~d}, J=3.5 \mathrm{~Hz}, 0.2 \mathrm{H}), 3.64(\mathrm{~d}, J$ $=3.6 \mathrm{~Hz}, 0.2 \mathrm{H}), 3.62(\mathrm{~d}, J=2.7 \mathrm{~Hz}, 0.4 \mathrm{H}), 3.59(\mathrm{~d}, J=9.3 \mathrm{~Hz}, 2 \mathrm{H}), 3.55(\mathrm{~d}, J=4.6$ $\mathrm{Hz}, 0.5 \mathrm{H}), 3.53$ (d, $J=4.6 \mathrm{~Hz}, 0.5 \mathrm{H}), 3.51-3.44$ (m, 4H), $3.37-3.36$ (m, 5H), $3.30-$ $3.27(\mathrm{~m}, 1 \mathrm{H})$.

${ }^{13} \mathbf{C}$ NMR $\left(125 \mathrm{MHz}, \mathrm{CDCl}_{3}\right) \delta 139.8,138.8,138.8,138.7,138.7,138.6,138.5,138.4$, $138.0,128.6,128.5,128.5,128.4,128.4,128.2,128.2,128.1,127.9,127.9,127.9,127.8$, $127.7,127.7,127.4,127.2,126.9,102.6,98.6,97.9,96.8,85.0,83.0,82.1,80.6,80.4$, 79.7, 79.0, 78.2, 77.8, 75.7, 75.5, 75.4, 75.1, 74.9, 73.8, 73.6, 73.5, 73.5, 73.4, 73.3, $70.1,69.7,69.2,68.4,68.3,68.1,55.4,55.30$. The ${ }^{1} \mathrm{H}$ NMR and ${ }^{13} \mathrm{C}$ NMR spectra coincide with the previous report. ${ }^{[10,17]}$

Methyl 2,3,4,6-tetra- $O$-benzyl- $\beta$-D-galactopyranosyl-(1 $\rightarrow 4)-2,3,6$-tri- $O$-benzyl- $\beta$ D-glucopyranosyl-( $1 \rightarrow 6)$-2,3,4-tri- $O$-benzyl- $\alpha$-D-glucopyranoside 28

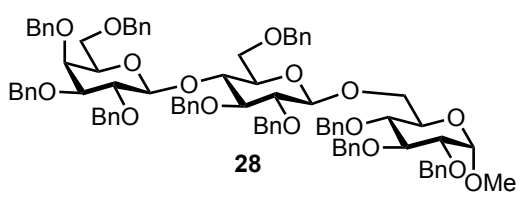


A solution of donor 10 (0.1944 g, $0.2 \mathrm{mmol}, 2$ equiv.) in $1.0 \mathrm{~mL}$ of THF was cooled to $-30{ }^{\circ} \mathrm{C}$ and treated with sodium hexamethyldisilazane ( $1 \mathrm{M}$ in THF, $0.2 \mathrm{~mL}, 0.2 \mathrm{mmol}$, 2 equiv.). After 10 minutes, this solution was transferred by syringe to a flask containing the solution of either $p$-nitrobenzenesulfonyl chloride $4 \mathrm{~h}(0.0442 \mathrm{~g}, 0.2 \mathrm{mmol}, 2$ equiv.) or 3,5-bis(trifluoromethyl)benzenesulfonyl chloride $4 \mathbf{i}(0.0623 \mathrm{~g}, 0.2 \mathrm{mmol}, 2$ equiv.) in $1.0 \mathrm{~mL}$ of THF that had been pre-cooled to $-30{ }^{\circ} \mathrm{C}$. The flask that contained the donor was then rinsed with an additional $0.5 \mathrm{~mL}$ of THF, and this rinse was then added to the donor and sulfonyl chloride reaction mixture. After this mixture has stirred for two hours at $-30{ }^{\circ} \mathrm{C}$, it was treated with a freshly prepared solution of the alkoxide acceptor (prepared by treating a solution of acceptor $2(0.0464 \mathrm{~g}, 0.1 \mathrm{mmol}, 1$ equiv.) in $0.5 \mathrm{~mL}$ of THF at $-30{ }^{\circ} \mathrm{C}$ with sodium hexamethyldisilazane $(0.1 \mathrm{~mL}, 0.1 \mathrm{mmol}, 1$ equiv.) and stirring for 10 minutes.). The flask that had contained the acceptor was rinsed with 0.5 $\mathrm{mL}$ of THF, and this rinse was then added to the glycosylation reaction. After 4 hours, the reaction was quenched with $0.05 \mathrm{~mL}$ of saturated aqueous ammonium chloride $\left(\mathrm{NH}_{4} \mathrm{Cl}\right)$, diluted with water, and extracted with diethyl ether $(4 \times 10 \mathrm{~mL})$. The combined organic phase was washed with brine $(20 \mathrm{~mL})$ and then dried $\left(\mathrm{Na}_{2} \mathrm{SO}_{4}\right)$, filtered, and concentrated under reduced pressure. The crude product was purified by silica gel flash column chromatography (19\% ethyl acetate in hexane) to afford trisaccharide 28 as a single $\beta$-isomer $(0.1002 \mathrm{~g}, 0.071 \mathrm{mmol}, 71 \%$ yield) when $\mathbf{4 h}$ was used as the promoter or $(0.1281 \mathrm{~g}, 0.090 \mathrm{mmol}, 90 \%$ yield) when $4 \mathbf{i}$ was used as the promoter.

${ }^{1} \mathbf{H}$ NMR $\left(500 \mathrm{MHz}, \mathrm{CDCl}_{3}\right) \delta 7.37-7.03(\mathrm{~m}, 50 \mathrm{H}), 5.01(\mathrm{~d}, J=10.6 \mathrm{~Hz}, 1 \mathrm{H}), 4.97-$ $4.95(\mathrm{~m}, 2 \mathrm{H}), 4.90(\mathrm{~d}, J=11.0 \mathrm{~Hz}, 1 \mathrm{H}), 4.83-4.73(\mathrm{~m}, 5 \mathrm{H}), 4.71-4.68(\mathrm{~m}, 5 \mathrm{H}), 4.60$ $(\mathrm{d}, J=3.5 \mathrm{~Hz}, 1 \mathrm{H}), 4.57-4.46(\mathrm{~m}, 3 \mathrm{H}), 4.44(\mathrm{~d}, J=7.7 \mathrm{~Hz}, 1 \mathrm{H}), 4.38-4.28(\mathrm{~m}, 3 \mathrm{H})$, $4.22(\mathrm{~d}, J=11.8 \mathrm{~Hz}, 1 \mathrm{H}), 4.14(\mathrm{~d}, J=9.1 \mathrm{~Hz}, 1 \mathrm{H}), 3.97$ (t, $J=9.3 \mathrm{~Hz}, 1 \mathrm{H}), 4.93-4.89$ $(\mathrm{m}, 2 \mathrm{H}), 3.83-3.68(\mathrm{~m}, 4 \mathrm{H}), 3.66(\mathrm{dd}, J=11.0,4.8 \mathrm{~Hz}, 1 \mathrm{H}), 3.55-3.48(\mathrm{~m}, 4 \mathrm{H}), 3.46$ $-3.37(\mathrm{~m}, 2 \mathrm{H}), 3.37-3.28(\mathrm{~m}, 6 \mathrm{H})$.

${ }^{13}$ C NMR (125 MHz, $\left.\mathrm{CDCl}_{3}\right) \delta 139.1,139.1,138.9,138.8,138.7,138.6,138.5,138.2$, 138.2, 128.5, 128.4, 128.4, 128.3, 128.3, 128.2, 128.2, 128.1, 128.1, 128.0, 127.9, 127.9, $127.9,127.8,127.7,127.7,127.6,127.5,127.5,127.4,127.4,127.3,127.1,104.0,102.8$, $98.1,83.2,82.6,82.0,81.6,80.0,79.9,78.0,76.7,75.7,75.4,75.4,75.3,75.0,74.8$, 74.7, 73.7, 73.4, 73.4, 73.1, 72.6, 70.0, 68.6, 68.4, 68.1, 55.2. The ${ }^{1} \mathrm{H}$ NMR and ${ }^{13} \mathrm{C}$ NMR spectra coincide with the previous report. ${ }^{[18]}$ 
Methyl 2,3,4-O-tribenzyl-6-O-(2,3,4,6-O-tetrabenzyl- $\beta$-D-galactopyranosyl)- $\alpha$-Dglucopyranoside 31

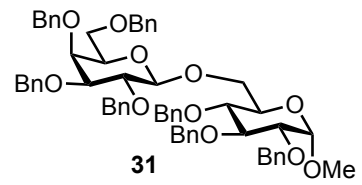

A solution of donor $29(0.1080 \mathrm{~g}, 0.2 \mathrm{mmol}, 3$ equiv. $)$ in $1.0 \mathrm{~mL}$ of THF was cooled to $-30{ }^{\circ} \mathrm{C}$ and treated with sodium hexamethyldisilazane $(1 \mathrm{M}$ in THF, $0.2 \mathrm{~mL}, 0.2 \mathrm{mmol}$, 3 equiv.). After 10 minutes, this solution was transferred by syringe to a flask containing the solution of either $p$-nitrobenzenesulfonyl chloride $4 \mathbf{h}(0.0442 \mathrm{~g}, 0.2 \mathrm{mmol}, 3$ equiv. $)$ or 3,5-bis(trifluoromethyl)benzenesulfonyl chloride $4 \mathbf{i}$ ( $0.0623 \mathrm{~g}, 0.2 \mathrm{mmol}, 3$ equiv.) in $1.0 \mathrm{~mL}$ of THF that had been pre-cooled to $-30^{\circ} \mathrm{C}$. The flask that contained the donor was then rinsed with an additional $0.5 \mathrm{~mL}$ of THF, and this rinse was then added to the donor and sulfonyl chloride reaction mixture. After this mixture has stirred for two hours at $-30^{\circ} \mathrm{C}$, it was treated with a freshly prepared solution of the alkoxide acceptor (prepared by treating a solution of acceptor $2(0.0309 \mathrm{~g}, 0.0667 \mathrm{mmol}, 1$ equiv.) in 0.7 $\mathrm{mL}$ of THF at $-30{ }^{\circ} \mathrm{C}$ with sodium hexamethyldisilazane $(0.067 \mathrm{~mL}, 0.0667 \mathrm{mmol}, 1$ equiv.) and stirring for 10 minutes.). The flask that had contained the acceptor was rinsed with $0.3 \mathrm{~mL}$ of THF, and this rinse was then added to the glycosylation reaction. After 8 hours, the reaction was quenched with $0.05 \mathrm{~mL}$ of saturated, aqueous ammonium chloride $\left(\mathrm{NH}_{4} \mathrm{Cl}\right)$, diluted with water, and extracted with diethyl ether $(4 \mathrm{x}$ $10 \mathrm{~mL})$. The combined organic phase was washed with brine $(20 \mathrm{~mL})$ and then dried $\left(\mathrm{Na}_{2} \mathrm{SO}_{4}\right)$, filtered, and concentrated under reduced pressure. The crude product was purified by silica gel flash column chromatography (15\% ethyl acetate in hexane) to afford disaccharide 31 (0.0408 g, $0.041 \mathrm{mmol}, 62 \%$ yield, $\beta: \alpha$ 12:1) when $\mathbf{4 h}$ was used as the promoter or $(0.0562 \mathrm{~g}, 0.057 \mathrm{mmol}, 85 \%$ yield, $\beta: \alpha 10: 1)$ when $4 \mathbf{i}$ was used as the promoter. The selectivity was determined by ${ }^{1} \mathrm{H}$ NMR integration of the anomeric signals of purified 31. The $\beta$ and $\alpha$ products did not separate significantly on silica gel, and care was taken to isolate the entire chromatographic band.

\section{$\beta$-isomer}

${ }^{1} \mathbf{H}$ NMR $\left(500 \mathrm{MHz}, \mathrm{CDCl}_{3}\right) \delta 7.47-7.07$ (m, 35H), $4.97-4.89(\mathrm{~m}, 3 \mathrm{H}), 4.77-4.70$ $(\mathrm{m}, 6 \mathrm{H}), 4.64(\mathrm{~d}, J=12.1 \mathrm{~Hz}, 1 \mathrm{H}), 4.59-4.53(\mathrm{~m}, 2 \mathrm{H}), 4.50(\mathrm{~d}, J=11.1 \mathrm{~Hz}, 1 \mathrm{H}), 4.45$ $-4.37(\mathrm{~m}, 2 \mathrm{H}), 4.30(\mathrm{~d}, J=7.7 \mathrm{~Hz}, 1 \mathrm{H}), 4.14(\mathrm{dd}, J=10.7,1.4 \mathrm{~Hz}, 1 \mathrm{H}), 3.97$ (t, $J=$ $9.3 \mathrm{~Hz}, 1 \mathrm{H}), 3.89$ (d, $J=2.5 \mathrm{~Hz}, 1 \mathrm{H}), 3.87-3.79$ (m, 2H), $3.64-3.58$ (m, 2H), 3.56 (dd, $J=9.1,5.4 \mathrm{~Hz}, 1 \mathrm{H}), 3.52-3.44(\mathrm{~m}, 4 \mathrm{H}), 3.29$ (s, 3H).

${ }^{13}$ C NMR $\left(125 \mathrm{MHz}, \mathrm{CDCl}_{3}\right) \delta 139.0,138.9,138.9,138.6,138.5,138.5,138.3,138.0$, $131.4,128.6,128.5,128.4,128.4,128.3,128.3,128.2,128.1,128.1,128.0,127.9,127.8$, $127.7,127.6,127.5,104.4,98.0,82.4,82.2,80.0,79.4,78.3,75.8,75.3,74.9,74.7,73.6$, 
73.5, 73.5, 73.0, 70.1, 68.8, 68.7, 55.3. The ${ }^{1} \mathrm{H}$ NMR and ${ }^{13} \mathrm{C}$ NMR spectra coincide with the previous report. ${ }^{[10]}$

$\alpha$-isomer

${ }^{1} \mathbf{H}$ NMR $\left(500 \mathrm{MHz}, \mathrm{CDCl}_{3}\right) \delta 7.41-7.15(\mathrm{~m}, 35 \mathrm{H}), 4.99(\mathrm{~d}, J=3.6 \mathrm{~Hz}, 1 \mathrm{H}), 4.96-$ $4.92(\mathrm{~m}, 2 \mathrm{H}), 4.84(\mathrm{~d}, J=11.0 \mathrm{~Hz}, 1 \mathrm{H}), 4.80(\mathrm{~d}, J=4.5 \mathrm{~Hz}, 1 \mathrm{H}), 4.78(\mathrm{~d}, J=5.6 \mathrm{~Hz}$, $1 \mathrm{H}), 4.75-4.66(\mathrm{~m}, 4 \mathrm{H}), 4.60-4.55(\mathrm{~m}, 2 \mathrm{H}), 4.54(\mathrm{~d}, J=4.1 \mathrm{~Hz}, 1 \mathrm{H}), 4.52(\mathrm{~d}, J=3.5$ $\mathrm{Hz}, 1 \mathrm{H}), 4.43(\mathrm{~d}, J=11.8 \mathrm{~Hz}, 1 \mathrm{H}), 4.36(\mathrm{~d}, J=11.8 \mathrm{~Hz}, 1 \mathrm{H}), 4.02(\mathrm{dd}, J=3.6,3.6 \mathrm{~Hz}$, $1 \mathrm{H}), 3.98-3.94(\mathrm{~m}, 2 \mathrm{H}), 3.92-3.88(\mathrm{~m}, 2 \mathrm{H}), 3.80-3.71(\mathrm{~m}, 3 \mathrm{H}), 3.58(\mathrm{t}, J=9.2 \mathrm{~Hz}$, $1 \mathrm{H}), 3.53-3.46(\mathrm{~m}, 2 \mathrm{H}), 3.40(\mathrm{dd}, J=9.6,3.6 \mathrm{~Hz}, 1 \mathrm{H}), 3.29(\mathrm{~s}, 3 \mathrm{H})$.

${ }^{13} \mathbf{C}$ NMR $\left(125 \mathrm{MHz}, \mathrm{CDCl}_{3}\right) \delta 139.1,139.0,138.9,138.9,138.6,138.4,138.2,128.6$, $128.5,128.5,128.4,128.4,128.3,128.1,128.1,128.0,127.8,127.8,127.7,127.6,127.5$, 98.1, 98.1, 82.2, 80.4, 78.4, 78.2, 76.7, 75.8, 75.3, 75.1, 74.9, 73.5, 73.5, 73.0, 72.7, 70.5, 69.6, 69.1, 66.6, 55.2, 29.9. The ${ }^{1} \mathrm{H}$ NMR and ${ }^{13} \mathrm{C}$ NMR spectra coincide with the previous report. ${ }^{[12]}$

6-O-(2,3,4,6-O-tetrabenzyl- $\beta$-D-galactopyranosyl)-1,2;3,4-O-diisopropylidene- $\alpha$ D-galactopyranoside 32

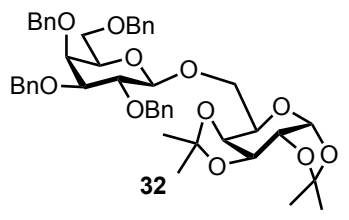

A solution of donor $29(0.2160 \mathrm{~g}, 0.4 \mathrm{mmol}, 3$ equiv. $)$ in $2.0 \mathrm{~mL}$ of THF was cooled to $-15{ }^{\circ} \mathrm{C}$ or $-40{ }^{\circ} \mathrm{C}$ and treated with sodium hexamethyldisilazane $(1 \mathrm{M}$ in THF, $0.4 \mathrm{~mL}$, $0.4 \mathrm{mmol}, 3$ equiv.). After 10 minutes, this solution was transferred by syringe to a flask containing the solution of either $p$-nitrobenzenesulfonyl chloride 4 h $(0.0884 \mathrm{~g}, 0.4$ mmol, 3 equiv., $-15^{\circ} \mathrm{C}$ ) or 3,5-bis(trifluoromethyl)benzenesulfonyl chloride $4 \mathbf{i}(0.1246$ g, $0.4 \mathrm{mmol}, 3$ equiv., $-40{ }^{\circ} \mathrm{C}$ ) in $2.0 \mathrm{~mL}$ of THF that had been pre-cooled to corresponding temperature. The flask that contained the donor was then rinsed with an additional $1.0 \mathrm{~mL}$ of THF, and this rinse was then added to the donor and sulfonyl chloride reaction mixture. After this mixture has stirred for two hours, it was treated with a freshly prepared solution of the alkoxide acceptor (prepared by treating a solution of acceptor 11 ( $0.0347 \mathrm{~g}, 0.133 \mathrm{mmol}, 1$ equiv.) in $1.4 \mathrm{~mL}$ of $\mathrm{THF}$ at $-15{ }^{\circ} \mathrm{C}$ or $-40{ }^{\circ} \mathrm{C}$ with sodium hexamethyldisilazane $(0.133 \mathrm{~mL}, 0.133 \mathrm{mmol}, 1$ equiv. $)$ and stirring for 10 minutes.). The flask that had contained the acceptor was rinsed with $0.6 \mathrm{~mL}$ of THF, and this rinse was then added to the glycosylation reaction. After 5 hours, the reaction was quenched with $0.1 \mathrm{~mL}$ of saturated aqueous ammonium chloride $\left(\mathrm{NH}_{4} \mathrm{Cl}\right)$, diluted with water, and extracted with diethyl ether $(4 \times 15 \mathrm{~mL})$. The combined organic phase was washed with brine $(30 \mathrm{~mL})$ and then dried $\left(\mathrm{Na}_{2} \mathrm{SO}_{4}\right)$, filtered, and concentrated under reduced pressure. The crude product was purified by silica gel flash column 
chromatography (15\% ethyl acetate in hexane) to afford disaccharide $\mathbf{3 2}$ as a single $\beta$ isomer $(0.0604 \mathrm{~g}, 0.077 \mathrm{mmol}, 58 \%$ yield $)$ when $\mathbf{4 h}$ was used as the promoter or ( $0.0957 \mathrm{~g}, 0.122 \mathrm{mmol}, 92 \%$ yield) when $4 \mathbf{i}$ was used as the promoter.

${ }^{1} \mathbf{H}$ NMR (500 MHz, $\left.\mathrm{CDCl}_{3}\right) \delta 7.52-7.18(\mathrm{~m}, 20 \mathrm{H}), 5.56(\mathrm{~d}, J=5.0 \mathrm{~Hz}, 1 \mathrm{H}), 5.05(\mathrm{~d}$, $J=11.0 \mathrm{~Hz}, 1 \mathrm{H}), 4.92(\mathrm{~d}, J=11.6 \mathrm{~Hz}, 1 \mathrm{H}), 4.78(\mathrm{~d}, J=11.9 \mathrm{~Hz}, 1 \mathrm{H}), 4.74-4.69$ (m, 2H), $4.60(\mathrm{~d}, J=11.6 \mathrm{~Hz}, 1 \mathrm{H}), 4.57(\mathrm{dd}, J=7.9,2.3 \mathrm{~Hz}, 1 \mathrm{H}), 4.45-4.36(\mathrm{~m}, 3 \mathrm{H}), 4.30$ $(\mathrm{dd}, J=5.0,2.4 \mathrm{~Hz}, 1 \mathrm{H}), 4.21(\mathrm{dd}, J=7.9,1.7 \mathrm{~Hz}, 1 \mathrm{H}), 4.12(\mathrm{dd}, J=10.6,3.5 \mathrm{~Hz}, 1 \mathrm{H})$, $4.08-4.06(\mathrm{~m}, 1 \mathrm{H}), 3.88$ (d, $J=2.7 \mathrm{~Hz}, 1 \mathrm{H}), 3.82$ (dd, $J=9.7,7.7 \mathrm{~Hz}, 1 \mathrm{H}), 3.68$ (dd, $J=10.6,7.5 \mathrm{~Hz}, 1 \mathrm{H}), 3.59-3.54(\mathrm{~m}, 2 \mathrm{H}), 3.53-3.47(\mathrm{~m}, 2 \mathrm{H}), 1.49(\mathrm{~s}, 3 \mathrm{H}), 1.43$ (s, $3 \mathrm{H}), 1.30(\mathrm{~d}, J=1.3 \mathrm{~Hz}, 6 \mathrm{H})$.

${ }^{13}$ C NMR (125 MHz, $\left.\mathrm{CDCl}_{3}\right) \delta 139.1,138.8,138.7,138.0,128.7,128.5,128.5,128.4$, 128.2 , 128.2, 128.0, 127.9, 127.6, 127.6, 127.4, 109.4, 108.7, 104.8, 96.5, 82.0, 79.2, 74.8, 74.6, 73.6, 73.6, 73.4, 73.2, 71.6, 70.9, 70.6, 69.7, 68.7, 67.5, 26.1, 26.1, 25.2, 24.5. The ${ }^{1} \mathrm{H}$ NMR and ${ }^{13} \mathrm{C}$ NMR spectra coincide with the previous report. ${ }^{[10]}$

Methyl 2- $O$-benzyl-3- $O$-(2,3,4,6-tetra- $O$-benzyl- $\beta$-D-galactopyranosyl)-(1 $\rightarrow 3)-4,6-$ $O$-benzylidene- $\alpha$-D-glucopyranoside 33

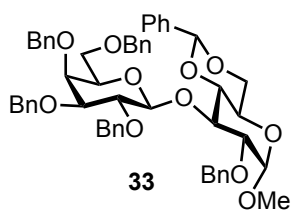

A solution of donor $29(0.1080 \mathrm{~g}, 0.2 \mathrm{mmol}, 3$ equiv. $)$ in $1.0 \mathrm{~mL}$ of THF was cooled to $-30{ }^{\circ} \mathrm{C}$ or $-40{ }^{\circ} \mathrm{C}$ and treated with sodium hexamethyldisilazane (1 M in THF, $0.2 \mathrm{~mL}$, 0.2 mmol, 3 equiv.). After 10 minutes, this solution was transferred by syringe to a flask containing the solution of either $p$-nitrobenzenesulfonyl chloride $4 \mathbf{h}(0.0442 \mathrm{~g}, 0.2$ mmol, 3 equiv., $-30^{\circ} \mathrm{C}$ ) or 3,5-bis(trifluoromethyl)benzenesulfonyl chloride $4 \mathbf{i}(0.0623$ g, $0.2 \mathrm{mmol}, 3$ equiv., $-40{ }^{\circ} \mathrm{C}$ ) in $1.0 \mathrm{~mL}$ of THF that had been pre-cooled to corresponding temperature. The flask that contained the donor was then rinsed with an additional $0.5 \mathrm{~mL}$ of THF, and this rinse was then added to the donor and sulfonyl chloride reaction mixture. After this mixture has stirred for two hours, it was treated with a freshly prepared solution of the alkoxide acceptor (prepared by treating a solution of acceptor 12 ( $0.0248 \mathrm{~g}, 0.0667 \mathrm{mmol}, 1$ equiv.) in $0.7 \mathrm{~mL}$ of THF at $-30{ }^{\circ} \mathrm{C}$ or $-40{ }^{\circ} \mathrm{C}$ with potassium hexamethyldisilazane $(0.067 \mathrm{~mL}, 0.0667 \mathrm{mmol}, 1$ equiv.) and stirring for 10 minutes.). The flask that had contained the acceptor was rinsed with $0.3 \mathrm{~mL}$ of THF, and this rinse was then added to the glycosylation reaction. The reaction was quenched with $0.05 \mathrm{~mL}$ of saturated, aqueous ammonium chloride $\left(\mathrm{NH}_{4} \mathrm{Cl}\right)$, diluted with water, and extracted with diethyl ether $(4 \times 10 \mathrm{~mL})$. The combined organic phase was washed with brine $(20 \mathrm{~mL})$ and then dried $\left(\mathrm{Na}_{2} \mathrm{SO}_{4}\right)$, filtered, and concentrated under reduced pressure. The crude product was purified by silica gel flash column 
chromatography ( $15 \%$ ethyl acetate in hexane) to afford disaccharide 33 ( 4 hrs, 0.0435 g, $0.049 \mathrm{mmol}, 73 \%$ yield, $\beta: \alpha$ 11:1) when $4 \mathrm{~h}$ was used as the promoter or (19 hrs, $0.0541 \mathrm{~g}, 0.061 \mathrm{mmol}, 91 \%$ yield, $\beta: \alpha$ 5:1) when $4 \mathbf{i}$ was used as the promoter. The selectivity was determined by ${ }^{1} \mathrm{H}$ NMR integration of the anomeric signals of purified 33. The $\beta$ and $\alpha$ products did not separate significantly on silica gel, and care was taken to isolate the entire chromatographic band.

\section{$\beta$-isomer}

${ }^{1} \mathbf{H}$ NMR $\left(500 \mathrm{MHz}, \mathrm{CDCl}_{3}\right) \delta 7.54-7.04(\mathrm{~m}, 30 \mathrm{H}), 5.50(\mathrm{~s}, 1 \mathrm{H}), 5.03(\mathrm{~d}, J=11.0 \mathrm{~Hz}$, $1 \mathrm{H}), 4.93(\mathrm{~d}, J=11.6 \mathrm{~Hz}, 1 \mathrm{H}), 4.80-4.74(\mathrm{~m}, 3 \mathrm{H}), 4.71-4.66(\mathrm{~m}, 2 \mathrm{H}), 4.60$ (d, $J=$ $11.6 \mathrm{~Hz}, 1 \mathrm{H}), 4.51(\mathrm{~d}, J=12.1 \mathrm{~Hz}, 1 \mathrm{H}), 4.44(\mathrm{~d}, J=3.8 \mathrm{~Hz}, 1 \mathrm{H}), 4.35-4.28(\mathrm{~m}, 2 \mathrm{H})$, $4.23(\mathrm{~d}, J=11.6 \mathrm{~Hz}, 1 \mathrm{H}), 4.19(\mathrm{dd}, J=10.2,4.6 \mathrm{~Hz}, 1 \mathrm{H}), 3.87-3.83(\mathrm{~m}, 2 \mathrm{H}), \quad 3.79$ $(\mathrm{td}, J=10.0,4.6 \mathrm{~Hz}, 1 \mathrm{H}), 3.69-3.65(\mathrm{~m}, 2 \mathrm{H}), 3.64-3.56(\mathrm{~m}, 2 \mathrm{H}), 3.47$ (dd, $J=9.7$, $2.9 \mathrm{~Hz}, 1 \mathrm{H}), 3.39$ (dd, $J=8.8,5.4 \mathrm{~Hz}, 1 \mathrm{H}), 3.34$ (s, 3H).

${ }^{13}$ C NMR (125 MHz, $\left.\mathrm{CDCl}_{3}\right) \delta 193.1,139.2,139.1,138.8,138.5,138.1,137.7,137.4$, $128.9,128.5,128.4,128.3,128.2,128.0,127.9,127.8,127.6,127.5,127.4,126.3,103.2$, 101.2, 99.2, 82.8, 80.8, 80.3, 79.8, 77.0, 75.2, 74.6, 74.2, 73.6, 73.0, 72.9, 69.2, 68.7, 62.2, 55.4. The ${ }^{1} \mathrm{H}$ NMR and ${ }^{13} \mathrm{C}$ NMR spectra coincide with the previous report. ${ }^{[19]}$

\section{a-isomer}

${ }^{1} \mathbf{H}$ NMR (500 MHz, $\left.\mathrm{CDCl}_{3}\right) \delta 7.46-6.94(\mathrm{~m}, 30 \mathrm{H}), 5.61(\mathrm{~d}, J=3.5 \mathrm{~Hz}, 1 \mathrm{H}), 5.43$ (s, $1 \mathrm{H}), 4.88(\mathrm{~d}, J=11.2 \mathrm{~Hz}, 1 \mathrm{H}), 4.85(\mathrm{~d}, J=11.8 \mathrm{~Hz}, 1 \mathrm{H}), 4.75-4.67(\mathrm{~m}, 2 \mathrm{H}), 4.60-$ $4.50(\mathrm{~m}, 4 \mathrm{H}), 4.44(\mathrm{~d}, J=12.4 \mathrm{~Hz}, 1 \mathrm{H}), 4.40-4.30(\mathrm{~m}, 4 \mathrm{H}), 4.21(\mathrm{dd}, J=10.2,4.8 \mathrm{~Hz}$, $1 \mathrm{H}), 3.99(\mathrm{dd}, J=9.8,3.5 \mathrm{~Hz}, 1 \mathrm{H}), 3.96-3.90(\mathrm{~m}, 2 \mathrm{H}), 3.83(\mathrm{td}, J=9.9,4.7 \mathrm{~Hz}, 1 \mathrm{H})$, $3.73(\mathrm{t}, J=9.4 \mathrm{~Hz}, 1 \mathrm{H}), 3.67(\mathrm{t}, J=10.3 \mathrm{~Hz}, 1 \mathrm{H}), 3.63-3.56(\mathrm{~m}, 2 \mathrm{H}), 3.54(\mathrm{t}, J=8.6$ $\mathrm{Hz}, 1 \mathrm{H}), 3.33$ (s, 3H).

${ }^{13} \mathbf{C}$ NMR $\left(125 \mathrm{MHz}, \mathrm{CDCl}_{3}\right) \delta 139.2,139.1,138.7,138.5,138.1,137.7,128.9,128.5$, $128.4,128.4,128.3,128.3,128.3,128.2,128.2,128.0,127.9,127.8,127.6,127.6,127.5$, $127.4,126.3,103.2,101.2,99.2,82.8,80.8,80.4,79.8,75.2,74.6,74.1,73.7,73.6,73.0$, 72.9, 69.2, 68.7, 62.2, 55.5. The ${ }^{1} \mathrm{H}$ NMR and ${ }^{13} \mathrm{C}$ NMR spectra coincide with the previous report. ${ }^{[16 a, 19]}$

Methyl-O-(2,3,4,6-tetra- $O$-benzyl- $\beta / \alpha$-D-galactopyranosyl)-(1 $\rightarrow 4)-2,3,6$-tri- $O$ benzyl- $\alpha$-D-glucopyranoside 34

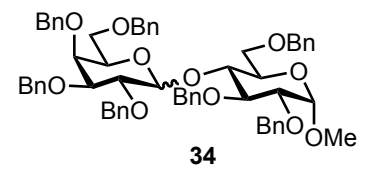

A solution of donor $29(0.2160 \mathrm{~g}, 0.4 \mathrm{mmol}, 3$ equiv. $)$ in $2.0 \mathrm{~mL}$ of THF was cooled to $-30{ }^{\circ} \mathrm{C}$ or $-40{ }^{\circ} \mathrm{C}$ and treated with sodium hexamethyldisilazane (1 M in THF, $0.4 \mathrm{~mL}$, $0.4 \mathrm{mmol}, 3$ equiv.). After 10 minutes, this solution was transferred by syringe to a flask 
containing the solution of either $p$-nitrobenzenesulfonyl chloride 4 h $(0.0884 \mathrm{~g}, 0.4$ mmol, 3 equiv., $-30^{\circ} \mathrm{C}$ ) or 3,5-bis(trifluoromethyl)benzenesulfonyl chloride $4 \mathbf{i}(0.1246$ g, $0.4 \mathrm{mmol}, 3$ equiv., $-40^{\circ} \mathrm{C}$ ) in $1.0 \mathrm{~mL}$ of THF that had been pre-cooled to corresponding temperature. The flask that contained the donor was then rinsed with an additional $1.0 \mathrm{~mL}$ of THF, and this rinse was then added to the donor and sulfonyl chloride reaction mixture. After this mixture has stirred for two hours, it was treated with a freshly prepared solution of the alkoxide acceptor (prepared by treating a solution of acceptor 16 (0.0618 g, $0.133 \mathrm{mmol}, 1$ equiv.) in $1.4 \mathrm{~mL}$ of $\mathrm{THF}$ at $-30{ }^{\circ} \mathrm{C}$ or $-40{ }^{\circ} \mathrm{C}$ with potassium hexamethyldisilazane $(0.133 \mathrm{~mL}, 0.133 \mathrm{mmol}, 1$ equiv. $)$ and stirring for 10 minutes.). The flask that had contained the acceptor was rinsed with $0.6 \mathrm{~mL}$ of THF, and this rinse was then added to the glycosylation reaction. After 20 hours, the reaction was quenched with $0.1 \mathrm{~mL}$ of saturated aqueous ammonium chloride $\left(\mathrm{NH}_{4} \mathrm{Cl}\right)$, diluted with water, and extracted with diethyl ether $(4 \times 15 \mathrm{~mL})$. The combined organic phase was washed with brine $(30 \mathrm{~mL})$ and then dried $\left(\mathrm{Na}_{2} \mathrm{SO}_{4}\right)$, filtered, and concentrated under reduced pressure. The crude product was purified by silica gel flash column chromatography ( $15 \%$ ethyl acetate in hexane) to afford disaccharide 34 (0.0879 g, $0.089 \mathrm{mmol}, 67 \%$ yield, $\beta: \alpha 6: 1)$ when $4 \mathrm{~h}$ was used as the promoter or $(0.0932 \mathrm{~g}, 0.094$ mmol, 71\% yield, $\beta: \alpha 5: 1$ ) when $\mathbf{4} \mathbf{i}$ was used as the promoter. The selectivity was determined by ${ }^{1} \mathrm{H}$ NMR integration of the anomeric signals of purified 34 . The $\beta$ and $\alpha$ products did not separate significantly on silica gel, and care was taken to isolate the entire chromatographic band.

The procedure below is the glycosylation promoted by 4-bromobenzenesulfonyl chloride $\mathbf{4 g}$ and disaccharide $\mathbf{3 4}$ was generated in 51\% yield, $\beta: \alpha$ 11:1.

A solution of donor $29(0.1621 \mathrm{~g}, 0.3 \mathrm{mmol}, 4$ equiv. $)$ in $1.5 \mathrm{~mL}$ of THF was cooled to $-40{ }^{\circ} \mathrm{C}$ and treated with sodium hexamethyldisilazane $(1 \mathrm{M}$ in THF, $0.3 \mathrm{~mL}, 0.3 \mathrm{mmol}$, 4 equiv.). After 10 minutes, this solution was transferred by syringe to a flask containing the solution of 4-bromobenzenesulfonyl chloride $4 \mathrm{~g}$ ( $0.0762 \mathrm{~g}, 0.3 \mathrm{mmol}, 4$ equiv.) in $1.5 \mathrm{~mL}$ of THF that had been pre-cooled to $-40{ }^{\circ} \mathrm{C}$. The flask that contained the donor was then rinsed with an additional $0.7 \mathrm{~mL}$ of THF, and this rinse was then added to the donor and sulfonyl chloride reaction mixture. After this mixture has stirred for two hours, it was treated with a freshly prepared solution of the alkoxide acceptor (prepared by treating a solution of acceptor $16(0.0348 \mathrm{~g}, 0.075 \mathrm{mmol}, 1$ equiv.) in $0.8 \mathrm{~mL}$ of THF at $-40{ }^{\circ} \mathrm{C}$ with potassium hexamethyldisilazane $(0.075 \mathrm{~mL}, 0.075 \mathrm{mmol}, 1$ equiv.) and stirring for 10 minutes.). The flask that had contained the acceptor was rinsed with 0.4 $\mathrm{mL}$ of THF, and this rinse was then added to the glycosylation reaction. After 46 hours, the reaction was quenched with $0.1 \mathrm{~mL}$ of saturated aqueous ammonium chloride $\left(\mathrm{NH}_{4} \mathrm{Cl}\right)$, diluted with water, and extracted with diethyl ether $(4 \times 15 \mathrm{~mL})$. The combined organic phase was washed with brine $(30 \mathrm{~mL})$ and then dried $\left(\mathrm{Na}_{2} \mathrm{SO}_{4}\right)$, 
filtered, and concentrated under reduced pressure. The crude product was purified by silica gel flash column chromatography (15\% ethyl acetate in hexane) to afford disaccharide 34 (0.0374 g, $0.038 \mathrm{mmol}, 51 \%$ yield, $\beta: \alpha$ 11:1). The selectivity was determined by ${ }^{1} \mathrm{H}$ NMR integration of the anomeric signals of purified 34 . The $\beta$ and $\alpha$ products did not separate significantly on silica gel, and care was taken to isolate the entire chromatographic band.

\section{$\beta$-isomer}

${ }^{1} \mathbf{H}$ NMR $\left(500 \mathrm{MHz}, \mathrm{CDCl}_{3}\right) \delta 7.49-7.02(\mathrm{~m}, 35 \mathrm{H}), 5.03(\mathrm{~d}, J=10.6 \mathrm{~Hz}, 1 \mathrm{H}), 4.97$ $(\mathrm{d}, J=11.4 \mathrm{~Hz}, 1 \mathrm{H}), 4.87-4.60(\mathrm{~m}, 7 \mathrm{H}), 4.56-4.51(\mathrm{~m}, 3 \mathrm{H}), 4.39-4.27(\mathrm{~m}, 3 \mathrm{H})$, $4.24(\mathrm{~d}, J=11.8 \mathrm{~Hz}, 1 \mathrm{H}), 3.92-3.88(\mathrm{~m}, 2 \mathrm{H}), 3.85-3.78(\mathrm{~m}, 2 \mathrm{H}), 3.74(\mathrm{dd}, J=9.6$, $7.8 \mathrm{~Hz}, 1 \mathrm{H}), 3.60(\mathrm{~d}, J=9.6 \mathrm{~Hz}, 1 \mathrm{H}), 3.56-3.41(\mathrm{~m}, 3 \mathrm{H}), 3.41-3.27(\mathrm{~m}, 6 \mathrm{H})$.

${ }^{13}$ C NMR (125 MHz, $\left.\mathrm{CDCl}_{3}\right) \delta 139.5,139.1,139.0,138.6,138.6,138.3,138.2,128.4$, $128.4,128.3,128.2,128.2,128.2,128.1,128.0,127.9,127.8,127.7,127.6,127.5,127.4$, $127.4,127.4,127.0,102.8,98.5,82.6,80.3,80.1,79.0,76.7,75.5,75.3,74.7,73.8,73.7$, 73.5, 73.2, 73.1, 72.6, 70.1, 68.3, 68.1, 55.3. The ${ }^{1} \mathrm{H}$ NMR and ${ }^{13} \mathrm{C}$ NMR spectra coincide with the previous report. ${ }^{[17]}$

\section{$\alpha$-isomer}

${ }^{1} \mathbf{H}$ NMR $\left(500 \mathrm{MHz}, \mathrm{CDCl}_{3}\right) \delta 7.39-7.02(\mathrm{~m}, 35 \mathrm{H}), 5.75(\mathrm{~d}, J=3.8 \mathrm{~Hz}, 1 \mathrm{H}), 4.97(\mathrm{~d}$, $J=11.5 \mathrm{~Hz}, 1 \mathrm{H}), 4.86(\mathrm{~d}, J=11.4 \mathrm{~Hz}, 1 \mathrm{H}), 4.81(\mathrm{~d}, J=11.5 \mathrm{~Hz}, 1 \mathrm{H}), 4.72-4.49(\mathrm{~m}$, 9H), $4.42(\mathrm{~d}, J=12.3 \mathrm{~Hz}, 1 \mathrm{H}), 4.30(\mathrm{~d}, J=11.6 \mathrm{~Hz}, 1 \mathrm{H}), 4.23(\mathrm{~d}, J=11.6 \mathrm{~Hz}, 1 \mathrm{H})$, $4.06(\mathrm{t}, J=9.1 \mathrm{~Hz}, 1 \mathrm{H}), 4.01-3.91(\mathrm{~m}, 3 \mathrm{H}), 3.88-3.77(\mathrm{~m}, 3 \mathrm{H}), 3.70(\mathrm{dd}, J=10.6$, $4.6 \mathrm{~Hz}, 1 \mathrm{H}), 3.64(\mathrm{dd}, J=10.6,2.2 \mathrm{~Hz}, 1 \mathrm{H}), 3.54(\mathrm{dd}, J=9.6,3.5 \mathrm{~Hz}, 1 \mathrm{H}), 3.48(\mathrm{t}, J=$ $8.2 \mathrm{~Hz}, 1 \mathrm{H}), 3.43(\mathrm{dd}, J=8.8,5.6 \mathrm{~Hz}, 1 \mathrm{H}), 3.37$ (s, 3H).

${ }^{13}$ C NMR (125 MHz, $\left.\mathrm{CDCl}_{3}\right) \delta 139.0,138.7,138.4,138.3,138.0,128.4,128.3,128.3$, $128.3,128.2,128.2,128.2,127.9,127.8,127.7,127.6,127.5,127.4,127.4,127.4,127.0$, $126.8,97.8,97.5,82.0,80.2,79.2,75.7,74.8,74.7,74.3,73.8,73.4,73.4,73.1,72.9$, $72.8,69.9,69.5,69.5,68.7,55.1$. The ${ }^{1} \mathrm{H}$ NMR and ${ }^{13} \mathrm{C}$ NMR spectra coincide with the previous report. ${ }^{[17]}$

\section{Methyl}

4-O-(2',3'-di-O-benzyl-4',6'-O-benzylidene- $\beta$-D-galactopyranosyl)-2,3,4-tri- $O$ benzyl- $\alpha$-D-glucopyranoside 35

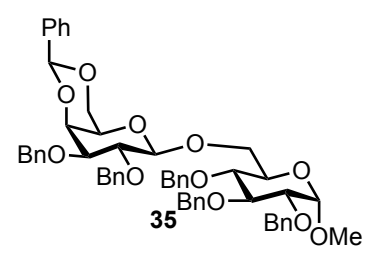


A solution of donor 30 ( $0.0976 \mathrm{~g}, 0.2 \mathrm{mmol}, 3$ equiv.) in $1.0 \mathrm{~mL}$ of THF was cooled to $-30{ }^{\circ} \mathrm{C}$ and treated with sodium hexamethyldisilazane ( $1 \mathrm{M}$ in THF, $0.2 \mathrm{~mL}, 0.2 \mathrm{mmol}$, 3 equiv.). After 10 minutes, this solution was transferred by syringe to a flask containing the solution of either $p$-nitrobenzenesulfonyl chloride $4 \mathrm{~h}(0.0442 \mathrm{~g}, 0.2 \mathrm{mmol}, 3$ equiv.) or 3,5-bis(trifluoromethyl)benzenesulfonyl chloride $4 \mathbf{i}$ ( $0.0623 \mathrm{~g}, 0.2 \mathrm{mmol}, 3$ equiv.) in $1.0 \mathrm{~mL}$ of THF that had been pre-cooled to $-30{ }^{\circ} \mathrm{C}$. The flask that contained the donor was then rinsed with an additional $0.5 \mathrm{~mL}$ of THF, and this rinse was then added to the donor and sulfonyl chloride reaction mixture. After this mixture has stirred for two hours at $-30{ }^{\circ} \mathrm{C}$, it was treated with a freshly prepared solution of the alkoxide acceptor (prepared by treating a solution of acceptor $2(0.0309 \mathrm{~g}, 0.0667 \mathrm{mmol}, 1$ equiv.) in 0.7 $\mathrm{mL}$ of THF at $-30{ }^{\circ} \mathrm{C}$ with sodium hexamethyldisilazane $(0.067 \mathrm{~mL}, 0.0667 \mathrm{mmol}, 1$ equiv.) and stirring for 10 minutes.). The flask that had contained the acceptor was rinsed with $0.3 \mathrm{~mL}$ of THF, and this rinse was then added to the glycosylation reaction. The reaction was quenched with $0.05 \mathrm{~mL}$ of saturated aqueous ammonium chloride $\left(\mathrm{NH}_{4} \mathrm{Cl}\right)$, diluted with water, and extracted with diethyl ether $(4 \times 10 \mathrm{~mL})$. The combined organic phase was washed with brine $(20 \mathrm{~mL})$ and then dried $\left(\mathrm{Na}_{2} \mathrm{SO}_{4}\right)$, filtered, and concentrated under reduced pressure. The crude product was purified by silica gel flash column chromatography (25\% ethyl acetate in hexane) to afford disaccharide 35 ( $24 \mathrm{hrs}, 0.0262 \mathrm{~g}, 0.029 \mathrm{mmol}, 44 \%$ yield, $\beta: \alpha$ 9.5:1) when $\mathbf{4 h}$ was used as the promoter or ( $7 \mathrm{hrs}, 0.0382 \mathrm{~g}, 0.043 \mathrm{mmol}, 64 \%$ yield, $\beta: \alpha 6: 1)$ when $4 \mathbf{i}$ was used as the promoter. The selectivity was determined by ${ }^{1} \mathrm{H}$ NMR integration of the anomeric signals of purified 35. The $\beta$ and $\alpha$ products did not separate significantly on silica gel, and care was taken to isolate the entire chromatographic band.

\section{$\beta$-isomer}

${ }^{1} \mathbf{H}$ NMR $\left(500 \mathrm{MHz}, \mathrm{CDCl}_{3}\right) \delta 7.61-7.01(\mathrm{~m}, 30 \mathrm{H}), 5.47(\mathrm{~s}, 1 \mathrm{H}), 4.97(\mathrm{~d}, J=10.9 \mathrm{~Hz}$, $1 \mathrm{H}), 4.92(\mathrm{~d}, J=10.8 \mathrm{~Hz}, 1 \mathrm{H}), 4.81-4.71(\mathrm{~m}, 6 \mathrm{H}), 4.64(\mathrm{~d}, J=12.1 \mathrm{~Hz}, 1 \mathrm{H}), 4.61(\mathrm{~d}$, $J=3.4 \mathrm{~Hz}, 1 \mathrm{H}), 4.52(\mathrm{~d}, J=11.2 \mathrm{~Hz}, 1 \mathrm{H}), 4.30(\mathrm{~d}, J=7.8 \mathrm{~Hz}, 1 \mathrm{H}), 4.26(\mathrm{~d}, J=12.2$ $\mathrm{Hz}, 1 \mathrm{H}), 4.18(\mathrm{~d}, J=10.9 \mathrm{~Hz}, 1 \mathrm{H}), 4.07$ (d, $J=3.4 \mathrm{~Hz}, 1 \mathrm{H}), 4.00-3.96(\mathrm{~m}, 2 \mathrm{H}), 3.90$ $-3.82(\mathrm{~m}, 2 \mathrm{H}), 3.68(\mathrm{dd}, J=11.1,5.0 \mathrm{~Hz}, 1 \mathrm{H}), 3.54-3.50(\mathrm{~m}, 3 \mathrm{H}), 3.34(\mathrm{~s}, 3 \mathrm{H}), 3.21$ (s, 1H).

${ }^{13}$ C NMR (126 MHz, $\left.\mathrm{CDCl}_{3}\right) \delta 139.1,139.0,138.7,138.6,138.3,138.1,129.0,128.6$, $128.5,128.5,128.4,128.3,128.2,128.1,128.1,128.0,127.9,127.8,127.8,127.6,127.5$, 126.6, 104.4, 101.4, 98.2, 82.2, 80.0, 79.5, 78.3, 78.3, 75.8, 75.4, 75.0, 73.9, 73.5, 72.0, 70.1, 69.3, 68.9, 66.6, 55.4. The ${ }^{1} \mathrm{H}$ NMR and ${ }^{13} \mathrm{C}$ NMR spectra coincide with the previous report. ${ }^{[20]}$

\section{a-isomer}

${ }^{1} \mathbf{H}$ NMR (500 MHz, $\left.\mathrm{CDCl}_{3}\right) \delta 7.57-7.15(\mathrm{~m}, 30 \mathrm{H}), 5.44(\mathrm{~s}, 1 \mathrm{H}), 5.04(\mathrm{~d}, J=3.4 \mathrm{~Hz}$, $1 \mathrm{H}), 4.97(\mathrm{~d}, J=10.8 \mathrm{~Hz}, 1 \mathrm{H}), 4.88(\mathrm{~d}, J=11.4 \mathrm{~Hz}, 1 \mathrm{H}), 4.81-4.64(\mathrm{~m}, 6 \mathrm{H}), 4.58$ (d, 
$J=12.1 \mathrm{~Hz}, 1 \mathrm{H}), 4.55-4.49(\mathrm{~m}, 2 \mathrm{H}), 4.12-4.08(\mathrm{~m}, 2 \mathrm{H}), 4.05(\mathrm{dd}, J=10.1,3.4 \mathrm{~Hz}$, $1 \mathrm{H}), 3.97(\mathrm{t}, J=9.3 \mathrm{~Hz}, 1 \mathrm{H}), 3.92(\mathrm{dd}, J=10.1,3.4 \mathrm{~Hz}, 1 \mathrm{H}), 3.86(\mathrm{~d}, J=11.1 \mathrm{~Hz}, 1 \mathrm{H})$, $3.80-3.74(\mathrm{~m}, 1 \mathrm{H}), 3.73(\mathrm{~d}, J=5.0 \mathrm{~Hz}, 1 \mathrm{H}), 3.69(\mathrm{~d}, J=11.0 \mathrm{~Hz}, 1 \mathrm{H}), 3.56(\mathrm{t}, J=9.3$ $\mathrm{Hz}, 1 \mathrm{H}), 3.48$ (s, 1H), 3.43 (dd, $J=9.6,3.6 \mathrm{~Hz}, 1 \mathrm{H}), 3.28(\mathrm{~s}, 3 \mathrm{H})$.

${ }^{13}$ C NMR (126 MHz, $\left.\mathrm{CDCl}_{3}\right) \delta 139.1,139.0,138.9,138.7,138.4,138.1,129.0,128.6$, $128.5,128.4,128.4,128.3,128.2$, 128.0, 127.9, 127.7, 127.7, 127.7, 127.6, 126.5, 101.2, $98.6,98.1,82.3,80.3,78.2,75.8,75.2,75.0,75.0,73.5,73.0,72.0,70.3,69.6,66.7$, 62.8, 55.2. The ${ }^{1} \mathrm{H}$ NMR and ${ }^{13} \mathrm{C}$ NMR spectra coincide with the previous report. ${ }^{[20]}$

Methyl-(2,3,4-tri- $O$-benzyl- $\beta$-L-fucopyranosyl)-(1 $\rightarrow 6)-2,3,4-$ tri- $O$-benzyl- $\alpha$-Dglucopyranoside 37

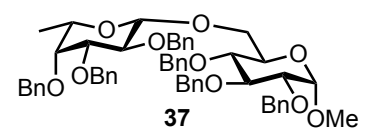

A solution of donor 36 ( $0.0868 \mathrm{~g}, 0.2 \mathrm{mmol}, 3$ equiv. $)$ in $1.0 \mathrm{~mL}$ of THF was cooled to $-30{ }^{\circ} \mathrm{C}$ and treated with sodium hexamethyldisilazane ( $1 \mathrm{M}$ in THF, $0.2 \mathrm{~mL}, 0.2 \mathrm{mmol}$, 3 equiv.). After 10 minutes, this solution was transferred by syringe to a flask containing the solution of either $p$-nitrobenzenesulfonyl chloride $4 \mathrm{~h}(0.0442 \mathrm{~g}, 0.2 \mathrm{mmol}, 3$ equiv.) or 3,5-bis(trifluoromethyl)benzenesulfonyl chloride $4 \mathbf{i}(0.0623 \mathrm{~g}, 0.2 \mathrm{mmol}, 3$ equiv.) in $1.0 \mathrm{~mL}$ of THF that had been pre-cooled to $-30{ }^{\circ} \mathrm{C}$. The flask that contained the donor was then rinsed with an additional $0.5 \mathrm{mLof}$ THF, and this rinse was then added to the donor and sulfonyl chloride reaction mixture. After this mixture has stirred for two hours at $-30{ }^{\circ} \mathrm{C}$, it was treated with a freshly prepared solution of the alkoxide acceptor (prepared by treating a solution of acceptor $2(0.0309 \mathrm{~g}, 0.0667 \mathrm{mmol}, 1$ equiv.) in 0.7 $\mathrm{mL}$ of THF at $-30{ }^{\circ} \mathrm{C}$ with sodium hexamethyldisilazane $(0.067 \mathrm{~mL}, 0.0667 \mathrm{mmol}, 1$ equiv.) and stirring for 10 minutes.). The flask that had contained the acceptor was rinsed with $0.3 \mathrm{~mL}$ of $\mathrm{THF}$, and this rinse was then added to the glycosylation reaction. After 8 hours, the reaction was quenched with $0.05 \mathrm{~mL}$ of saturated, aqueous ammonium chloride $\left(\mathrm{NH}_{4} \mathrm{Cl}\right)$, diluted with water, and extracted with diethyl ether $(4 \mathrm{x}$ $10 \mathrm{~mL})$. The combined organic phase was washed with brine $(20 \mathrm{~mL})$ and then dried $\left(\mathrm{Na}_{2} \mathrm{SO}_{4}\right)$, filtered, and concentrated under reduced pressure. The crude product was purified by silica gel flash column chromatography (18\% ethyl acetate in hexane) to afford disaccharide 37 as a single $\beta$-isomer ( $0.0262 \mathrm{~g}, 0.030 \mathrm{mmol}, 45 \%$ yield) when 4h was used as the promoter or $(0.0321 \mathrm{~g}, 0.036 \mathrm{mmol}, 54 \%$ yield $)$ when $4 \mathbf{i}$ was used as the promoter. (With the promoter 4-bromobenzenesulfonyl chloride $\mathbf{4 g}$, the disaccharide 37 was generated as a single $\beta$-isomer in $60 \%$ yield).

${ }^{1} \mathbf{H}$ NMR (500 MHz, $\left.\mathrm{CDCl}_{3}\right) \delta 7.45$ - $7.14(\mathrm{~m}, 30 \mathrm{H}), 4.99-4.95(\mathrm{~m}, 3 \mathrm{H}), 4.90-4.61$ (m, 9H), $4.61-4.52(\mathrm{~m}, 2 \mathrm{H}), 4.40(\mathrm{~d}, J=7.5 \mathrm{~Hz}, 1 \mathrm{H}), 4.21-4.12(\mathrm{~m}, 1 \mathrm{H}), 3.97$ (t, $J$ 
$=9.1 \mathrm{~Hz}, 1 \mathrm{H}), 3.84-3.70(\mathrm{~m}, 3 \mathrm{H}), 3.66(\mathrm{t}, J=9.3 \mathrm{~Hz}, 1 \mathrm{H}), 3.56-3.46(\mathrm{~m}, 2 \mathrm{H}), 3.46$

$-3.39(\mathrm{~m}, 2 \mathrm{H}), 3.32(\mathrm{~s}, 3 \mathrm{H}), 1.16(\mathrm{~d}, J=6.1 \mathrm{~Hz}, 3 \mathrm{H})$.

${ }^{13}$ C NMR $\left(125 \mathrm{MHz}, \mathrm{CDCl}_{3}\right) \delta 139.0,139.0,138.8,138.8,138.5,138.3,128.4,128.4$, $128.4,128.3,128.3,128.2,128.2,128.2,128.1,128.0,127.9,127.8,127.6,127.6,127.5$, 127.5, 127.4, 103.8, 98.1, 82.5, 82.0, 80.3, 79.5, 77.8, 76.7, 75.7, 75.1, 75.1, 74.6, 73.5, 73.2, 70.4, 70.1, 67.5, 55.1, 16.9. The ${ }^{1} \mathrm{H}$ NMR and ${ }^{13} \mathrm{C}$ NMR spectra coincide with the previous report. ${ }^{[21]}$

\section{Methyl-(2,3,4-tri- $O$-benzyl- $\beta / \alpha$-L-fucopyranosyl)-( $\rightarrow 3$ )-2- $O$-benzyl-4,6- $O$ - benzylidine- $\alpha$-D-glucopyranoside 38}

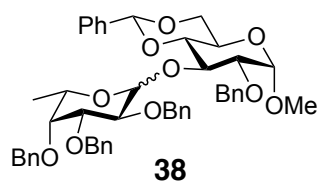

A solution of donor $36(0.1737 \mathrm{~g}, 0.4 \mathrm{mmol}, 4$ equiv. $)$ in $2.0 \mathrm{~mL}$ of THF was cooled to $-40{ }^{\circ} \mathrm{C}$ and treated with sodium hexamethyldisilazane $(1 \mathrm{M}$ in THF, $0.4 \mathrm{~mL}, 0.4 \mathrm{mmol}$, 4 equiv.). After 10 minutes, this solution was transferred by syringe to a flask containing the solution of 4-fluorobenzenesulfonyl chloride $4 \mathrm{~m}(0.0776 \mathrm{~g}, 0.4 \mathrm{mmoL})$ in $2.0 \mathrm{~mL}$ of THF that had been pre-cooled to $-40{ }^{\circ} \mathrm{C}$. The flask that contained the donor was then rinsed with an additional $1.0 \mathrm{~mL}$ of $\mathrm{THF}$, and this rinse was then added to the donor and sulfonyl chloride reaction mixture. After this mixture has stirred for two hours at $40{ }^{\circ} \mathrm{C}$, it was treated with a freshly prepared solution of the alkoxide acceptor (prepared by treating a solution of acceptor $12(0.0372 \mathrm{~g}, 0.1 \mathrm{mmol}, 1$ equiv.) in $0.8 \mathrm{~mL}$ of THF at $-40{ }^{\circ} \mathrm{C}$ with potassium hexamethyldisilazane $(0.1 \mathrm{~mL}, 0.1 \mathrm{mmol}, 1$ equiv. $)$ and stirring for 10 minutes.). The flask that had contained the acceptor was rinsed with 0.5 $\mathrm{mL}$ of THF, and this rinse was then added to the glycosylation reaction. After 72 hours, the reaction was quenched with $0.1 \mathrm{~mL}$ of saturated aqueous ammonium chloride $\left(\mathrm{NH}_{4} \mathrm{Cl}\right)$, diluted with water, and extracted with diethyl ether $(4 \times 20 \mathrm{~mL})$. The combined organic phase was washed with brine $(40 \mathrm{~mL})$ and then dried $\left(\mathrm{Na}_{2} \mathrm{SO}_{4}\right)$, filtered, and concentrated under reduced pressure. The crude product was purified by silica gel flash column chromatography (17\% ethyl acetate in hexane) to afford disaccharide 38 (34\% yield, $\beta: \alpha$ 11:1). The selectivity was determined by crude ${ }^{1} \mathrm{H}$ NMR analysis.

This procedure was followed when other sulfonates were used as the promoters.

\section{$\beta$-isomer}

${ }^{1} \mathbf{H}$ NMR (500 MHz, $\left.\mathrm{CDCl}_{3}\right) \delta 7.63-7.06(\mathrm{~m}, 25 \mathrm{H}), 5.28(\mathrm{~s}, 1 \mathrm{H}), 5.01(\mathrm{~d}, J=11.7 \mathrm{~Hz}$, $1 \mathrm{H}), 4.95-4.89(\mathrm{~m}, 2 \mathrm{H}), 4.84(\mathrm{~d}, J=7.7 \mathrm{~Hz}, 1 \mathrm{H}), 4.81-4.68(\mathrm{~m}, 4 \mathrm{H}), 4.67-4.62(\mathrm{~m}$, 2H), $4.39(\mathrm{t}, J=9.1 \mathrm{~Hz}, 1 \mathrm{H}), 4.24(\mathrm{dd}, J=10.2,4.8 \mathrm{~Hz}, 1 \mathrm{H}), 3.82-3.76(\mathrm{~m}, 2 \mathrm{H})$, 
$3.61(\mathrm{t}, J=10.3 \mathrm{~Hz}, 1 \mathrm{H}), 3.58-3.42(\mathrm{~m}, 4 \mathrm{H}), 3.41-3.32(\mathrm{~m}, 4 \mathrm{H}), 1.18(\mathrm{~d}, J=6.3 \mathrm{~Hz}$, $3 \mathrm{H})$.

${ }^{13}$ C NMR (125 MHz, $\left.\mathrm{CDCl}_{3}\right) \delta 139.5,139.0,138.8,138.6,137.4,128.6,128.3,128.3$, 128.1, 128.0, 128.0, 127.7, 127.6, 127.6, 127.5, 127.4, 127.1, 126.1, 103.3, 101.1, 99.5, 82.5, 82.3, 80.3, 78.1, 77.2, 76.0, 74.8, 74.7, 73.7, 73.0, 70.3, 69.1, 61.8, 55.3, 17.0. The ${ }^{1} \mathrm{H}$ NMR and ${ }^{13} \mathrm{C}$ NMR spectra coincide with the previous report. ${ }^{[21]}$

$\alpha$-isomer

${ }^{1} \mathbf{H}$ NMR $\left(500 \mathrm{MHz}, \mathrm{CDCl}_{3}\right) \delta 7.57-7.00(\mathrm{~m}, 25 \mathrm{H}), 5.51(\mathrm{~d}, J=3.7 \mathrm{~Hz}, 1 \mathrm{H}), 5.46(\mathrm{~s}$, $1 \mathrm{H}), 4.88-4.81(\mathrm{~m}, 2 \mathrm{H}), 4.75-4.61(\mathrm{~m}, 4 \mathrm{H}), 4.61-4.52(\mathrm{~m}, 2 \mathrm{H}), 4.49(\mathrm{~d}, J=3.6$ $\mathrm{Hz}, 1 \mathrm{H}), 4.30(\mathrm{t}, J=9.4 \mathrm{~Hz}, 1 \mathrm{H}), 4.26-4.17(\mathrm{~m}, 2 \mathrm{H}), 4.03(\mathrm{dd}, J=10.2,3.7 \mathrm{~Hz}, 1 \mathrm{H})$, $3.96(\mathrm{dd}, J=10.2,2.7 \mathrm{~Hz}, 1 \mathrm{H}), 3.83(\mathrm{td}, J=10.0,4.7 \mathrm{~Hz}, 1 \mathrm{H}), 3.73-3.63(\mathrm{~m}, 2 \mathrm{H})$, $3.60(\mathrm{t}, J=9.5 \mathrm{~Hz}, 1 \mathrm{H}), 3.51-3.50(\mathrm{~m}, 1 \mathrm{H}), 3.33(\mathrm{~s}, 3 \mathrm{H}), 0.80(\mathrm{~d}, J=6.4 \mathrm{~Hz}, 3 \mathrm{H})$.

${ }^{13}$ C NMR (125 MHz, $\left.\mathrm{CDCl}_{3}\right) \delta 139.0,138.8,138.5,138.3,137.5,129.1,128.4,128.3$, $128.3,128.2,128.1,127.9,127.7,127.6,127.4,127.3,127.3,126.2,101.8,98.8,97.5$, 81.1, 80.0, 79.8, 18.0, 75.9, 74.8, 73.2, 72.9, 72.8, 72.5, 69.2, 66.0, 62.4, 55.3, 16.3 . The ${ }^{1} \mathrm{H}$ NMR and ${ }^{13} \mathrm{C}$ NMR spectra coincide with the previous report. ${ }^{[21]}$

Methyl (2,3,4,6-tetra- $O$-benzyl- $\beta$-D-glucopyranosyl)-(1 $\rightarrow 6)-2,3,4-$ tri- $O$-methyl- $\alpha$ D-glucopyranoside 40

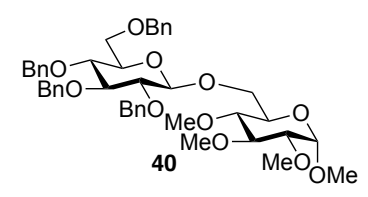

A solution of donor $1(0.1080 \mathrm{~g}, 0.2 \mathrm{mmol}, 2$ equiv. $)$ in $1.0 \mathrm{~mL}$ of THF was cooled to $30{ }^{\circ} \mathrm{C}$ and treated with sodium hexamethyldisilazane $(1 \mathrm{M}$ in THF, $0.2 \mathrm{~mL}, 0.2 \mathrm{mmol}$, 2 equiv.). After 10 minutes, this solution was transferred by syringe to a flask containing the solution of either $p$-nitrobenzenesulfonyl chloride $4 \mathbf{h}$ ( $0.0442 \mathrm{~g}, 0.2 \mathrm{mmol}, 2$ equiv.) or 3,5-bis(trifluoromethyl)benzenesulfonyl chloride $4 \mathbf{i}$ ( $0.0623 \mathrm{~g}, 0.2 \mathrm{mmol}, 2$ equiv.) in $1.0 \mathrm{~mL}$ of THF that had been pre-cooled to $-30{ }^{\circ} \mathrm{C}$. The flask that contained the donor was then rinsed with an additional $0.5 \mathrm{~mL}$ of THF, and this rinse was then added to the donor and sulfonyl chloride reaction mixture. After this mixture has stirred for two hours at $-30^{\circ} \mathrm{C}$, it was treated with a freshly prepared solution of the alkoxide acceptor (prepared by treating a solution of acceptor 39 (0.0236 g, $0.1 \mathrm{mmol}, 1$ equiv.) in $0.5 \mathrm{~mL}$ of THF at $-30{ }^{\circ} \mathrm{C}$ with sodium hexamethyldisilazane $(0.1 \mathrm{~mL}, 0.1 \mathrm{mmol}, 1$ equiv.) and stirring for 10 minutes.). The flask that had contained the acceptor was rinsed with 0.5 $\mathrm{mL}$ of THF, and this rinse was then added to the glycosylation reaction. After 3 hours, 
the reaction was quenched with $0.05 \mathrm{~mL}$ of saturated aqueous ammonium chloride $\left(\mathrm{NH}_{4} \mathrm{Cl}\right)$, diluted with water, and extracted with diethyl ether $(4 \times 10 \mathrm{~mL})$. The combined organic phase was washed with brine $(20 \mathrm{~mL})$ and then dried $\left(\mathrm{Na}_{2} \mathrm{SO}_{4}\right)$, filtered, and concentrated under reduced pressure. The crude product was purified by silica gel flash column chromatography (25\% ethyl acetate in hexane) to afford disaccharide 40 as a single $\beta$-isomer (0.0682 g, $0.090 \mathrm{mmol}, 90 \%$ yield) when $\mathbf{4 h}$ was used as the promoter or $(0.0691 \mathrm{~g}, 0.091 \mathrm{mmol}, 91 \%$ yield $)$ when $4 \mathbf{i}$ was used as the promoter. The selectivity was determined by crude ${ }^{1} \mathrm{H}$ NMR analysis.

${ }^{1} \mathbf{H}$ NMR $(500 \mathrm{MHz}, \mathrm{CDCl} 3) \delta 7.52-7.03(\mathrm{~m}, 21 \mathrm{H}), 5.10(\mathrm{~d}, J=11.0 \mathrm{~Hz}, 1 \mathrm{H}), 4.99$ $(\mathrm{d}, J=10.9 \mathrm{~Hz}, 1 \mathrm{H}), 4.91-4.82(\mathrm{~m}, 4 \mathrm{H}), 4.70-4.60(\mathrm{~m}, 3 \mathrm{H}), 4.55(\mathrm{~d}, J=7.8 \mathrm{~Hz}, 1 \mathrm{H})$, $4.32-4.24(\mathrm{~m}, 1 \mathrm{H}), 3.89-3.71(\mathrm{~m}, 5 \mathrm{H}), 3.71-3.64(\mathrm{~m}, 4 \mathrm{H}), 3.64-3.51(\mathrm{~m}, 9 \mathrm{H})$, $3.43(\mathrm{~s}, 3 \mathrm{H}), 3.28(\mathrm{dd}, J=9.6,3.6 \mathrm{~Hz}, 1 \mathrm{H}), 3.22(\mathrm{t}, J=9.2 \mathrm{~Hz}, 1 \mathrm{H})$.

${ }^{13}$ C NMR (125 MHz, CDCl3) $\delta$ 138.7, 138.5, 138.3, 138.2, 128.5, 128.4, 128.1, 128.0, $127.9,127.8,127.7,127.6,127.6,104.0,97.4,84.9,83.5,82.3,81.9,79.9,78.0,75.8$, 75.2, 75.1, 74.9, 73.5, 69.9, 69.1, 68.9, 60.8, 60.4, 59.0, 55.2. The ${ }^{1} \mathrm{H}$ NMR and ${ }^{13} \mathrm{C}$ NMR spectra coincide with the previous report. ${ }^{[22]}$ 


\subsection{Experimental data for variable temperature NMR study}

$p$-nitrobenzenesulfonyl 2,3,4,6-tetra- $O$-benzyl- $\alpha$-D-glucopyranoside

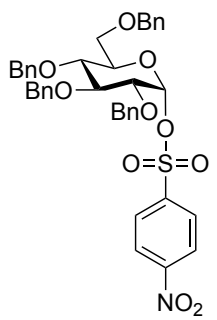

A solution of donor 1 ( $0.0540 \mathrm{~g}, 0.1 \mathrm{mmol}, 1$ equiv. $)$ in $0.5 \mathrm{~mL}$ of THF- $\mathrm{d}_{8}$ was cooled to $-30{ }^{\circ} \mathrm{C}$ and treated with sodium hexamethyldisilazane $(1 \mathrm{M}$ in THF, $0.1 \mathrm{~mL}, 0.1$ mmol, 1 equiv.). After 10 minutes, this solution was transferred by syringe to a flask containing the solution of $p$-nitrobenzenesulfonyl chloride $4 \mathrm{~h}(0.0221 \mathrm{~g}, 0.1 \mathrm{mmol}, 1$ equiv.) in $0.5 \mathrm{~mL}$ of $\mathrm{THF}-\mathrm{d}_{8}$ that had been pre-cooled to $-30{ }^{\circ} \mathrm{C}$. The solution maintained at $-30{ }^{\circ} \mathrm{C}$ for $2 \mathrm{hrs}$, transferred by syringe to a pre-cooled $5 \mathrm{~mm}$ Low Pressure/Vacuum Valve NMR tube, and promptly inserted into the NMR instrument probe pre-cooled to $-30{ }^{\circ} \mathrm{C}$ for ${ }^{1} \mathrm{H}$ NMR, ${ }^{13} \mathrm{C}$ NMR, and 2D-Gradient HSQC data acquisition in Figure S1. The temperature was maintained for 1 hour, then warmed by 15 degrees every 15 minutes. At each 15 mins interval, the ${ }^{1} \mathrm{H}$ NMR spectrum was recorded.

${ }^{1}$ H NMR (500 MHz, THF-d $)$ ) $\delta .22(\mathrm{~d}, J=8.6 \mathrm{~Hz}, 2 \mathrm{H}), 8.15(\mathrm{~d}, J=8.6 \mathrm{~Hz}, 2 \mathrm{H}), 7.29$ $-7.11(\mathrm{~m}, 20 \mathrm{H}), 6.18(\mathrm{~d}, J=3.2 \mathrm{~Hz}, 1 \mathrm{H}), 4.87(\mathrm{~d}, J=11.1 \mathrm{~Hz}, 1 \mathrm{H}), 4.79-4.74(\mathrm{~m}$, $2 \mathrm{H}), 4.63-4.62(\mathrm{~m}, 2 \mathrm{H}), 4.49(\mathrm{~d}, J=11.0 \mathrm{~Hz}, 1 \mathrm{H}), 4.37-4.31(\mathrm{~m}, 2 \mathrm{H}), 3.79(\mathrm{t}, J=$ $9.3 \mathrm{~Hz}, 1 \mathrm{H}), 3.70(\mathrm{dd}, J=9.6,3.1 \mathrm{~Hz}, 1 \mathrm{H}), 3.64$ (t, $J=9.5 \mathrm{~Hz}, 1 \mathrm{H}), 3.53(\mathrm{~s}, 1 \mathrm{H}), 3.50$ $-3.49(\mathrm{~m}, 1 \mathrm{H}), 3.10(\mathrm{~d}, J=10.3 \mathrm{~Hz}, 1 \mathrm{H})$.

${ }^{13}$ C NMR (125 MHz, THF-d 8$) \delta 150.4,143.0,138.8,138.3,138.1,137.8,129.1,128.0$, $127.9,127.9,127.8,127.8,127.7,127.5,127.4,127.4,127.4,127.3,127.3,127.3,127.2$, $127.1,127.1,124.1,100.0,80.8,78.1,76.0,75.0,74.7,73.0,72.4,72.3$. 
(a)

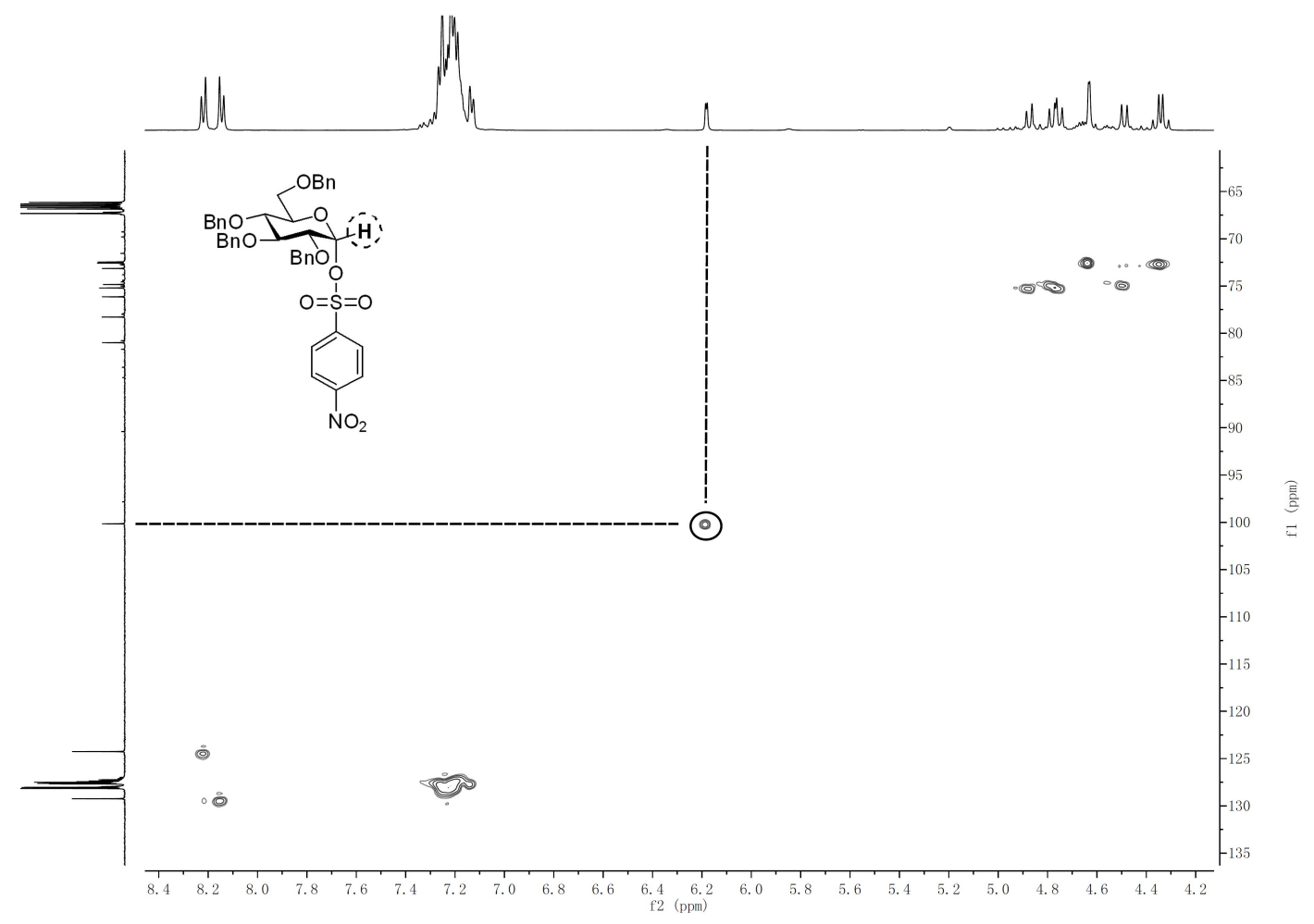

(b)

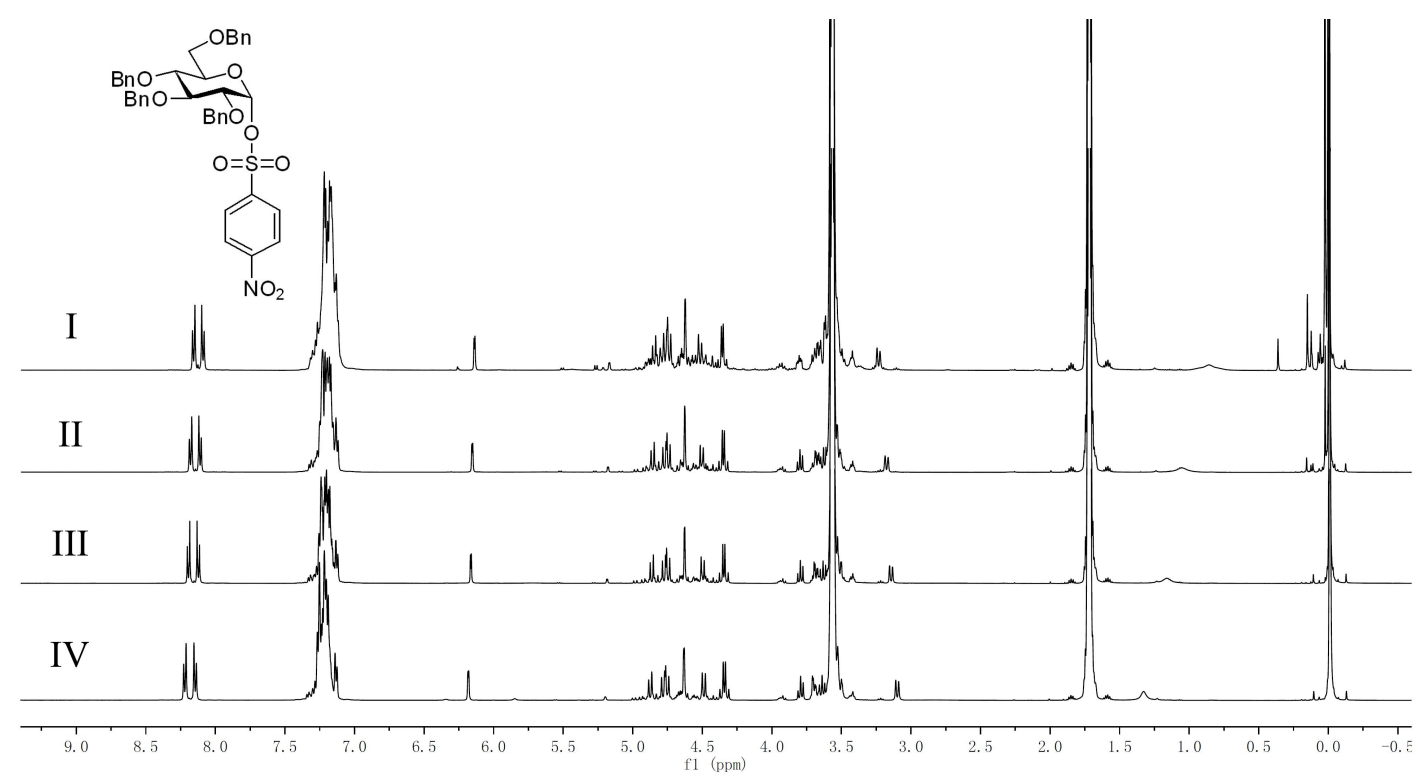

Figure S1. VT-NMR mechanistic studies. (a) 2D Gradient HSQC NMR spectrum of $\alpha$-glucosyl nosylate at $-30{ }^{\circ} \mathrm{C}$. (b) ${ }^{1} \mathrm{H}$ NMR spectra to evaluate the stability of the $\alpha$ glucosyl nosylate in THF-d 8 at: (I) $25^{\circ} \mathrm{C}$, (II) $0{ }^{\circ} \mathrm{C}$, (III) $-15{ }^{\circ} \mathrm{C}$, (IV) $-30{ }^{\circ} \mathrm{C}$. 


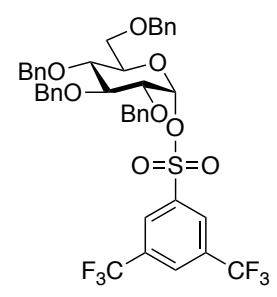

A solution of donor 1 ( $0.0540 \mathrm{~g}, 0.1 \mathrm{mmol}, 1$ equiv. $)$ in $0.5 \mathrm{~mL}$ of THF- $\mathrm{d}_{8}$ was cooled to $-60{ }^{\circ} \mathrm{C}$ and treated with sodium hexamethyldisilazane $(1 \mathrm{M}$ in THF, $0.1 \mathrm{~mL}, 0.1$ mmol, 1 equiv.). After 10 minutes, this solution was transferred by syringe to a flask containing the solution of 3,5-bis(trifluoromethyl)benzenesulfonyl chloride $4 \mathbf{i}(0.0312$ g, $0.1 \mathrm{mmol}, 1$ equiv.) in $0.5 \mathrm{~mL}$ of THF- $\mathrm{d}_{8}$ that had been pre-cooled to $-60{ }^{\circ} \mathrm{C}$. The solution maintained at $-60{ }^{\circ} \mathrm{C}$ for $2 \mathrm{hrs}$, transferred by syringe to a pre-cooled $5 \mathrm{~mm}$ Low Pressure/Vacuum Valve NMR tube, and promptly inserted into the NMR instrument probe pre-cooled to $-60{ }^{\circ} \mathrm{C}$ for ${ }^{1} \mathrm{H}$ NMR, ${ }^{13} \mathrm{C}$ NMR, and 2D-Gradient HSQC data acquisition in Figure S2. The temperature was maintained for 30 minutes, then warmed by 20 degrees every 20 minutes. At each 15 mins interval, the ${ }^{1} \mathrm{H}$ NMR spectrum was recorded.

${ }^{1}$ H NMR (500 MHz, THF-d 8$) \delta 8.74(\mathrm{~s}, 2 \mathrm{H}), 8.53(\mathrm{~s}, 1 \mathrm{H}), 7.34-7.08(\mathrm{~m}, 20 \mathrm{H}), 6.28$ $(\mathrm{d}, J=3.3 \mathrm{~Hz}, 1 \mathrm{H}), 4.90(\mathrm{~d}, J=11.2 \mathrm{~Hz}, 1 \mathrm{H}), 4.81-4.75(\mathrm{~m}, 2 \mathrm{H}), 4.70(\mathrm{~d}, J=11.2$ $\mathrm{Hz}, 1 \mathrm{H}), 4.59$ (d, $J=11.3 \mathrm{~Hz}, 1 \mathrm{H}), 4.49$ (d, $J=10.8 \mathrm{~Hz}, 1 \mathrm{H}), 4.33-4.36(\mathrm{~m}, 2 \mathrm{H}), 3.82$ $(\mathrm{t}, J=9.4 \mathrm{~Hz}, 1 \mathrm{H}), 3.77-3.66(\mathrm{~m}, 3 \mathrm{H}), 3.50-3.66(\mathrm{~m}, 1 \mathrm{H}), 3.00(\mathrm{~d}, J=10.5 \mathrm{~Hz}, 1 \mathrm{H})$.

${ }^{13}$ C NMR (125 MHz, THF-d 8$) \delta 140.4,138.9,138.5,138.1,137.8,132.1,131.9,129.0$, $128.2,128.2,128.1,128.1,128.0,127.9,127.6,127.6,127.5,127.5,127.4,127.4,127.3$, $127.3,124.0,121.8,100.3,80.6,78.0,75.8,75.2,74.8,72.9,72.4,72.0$. 
(a)

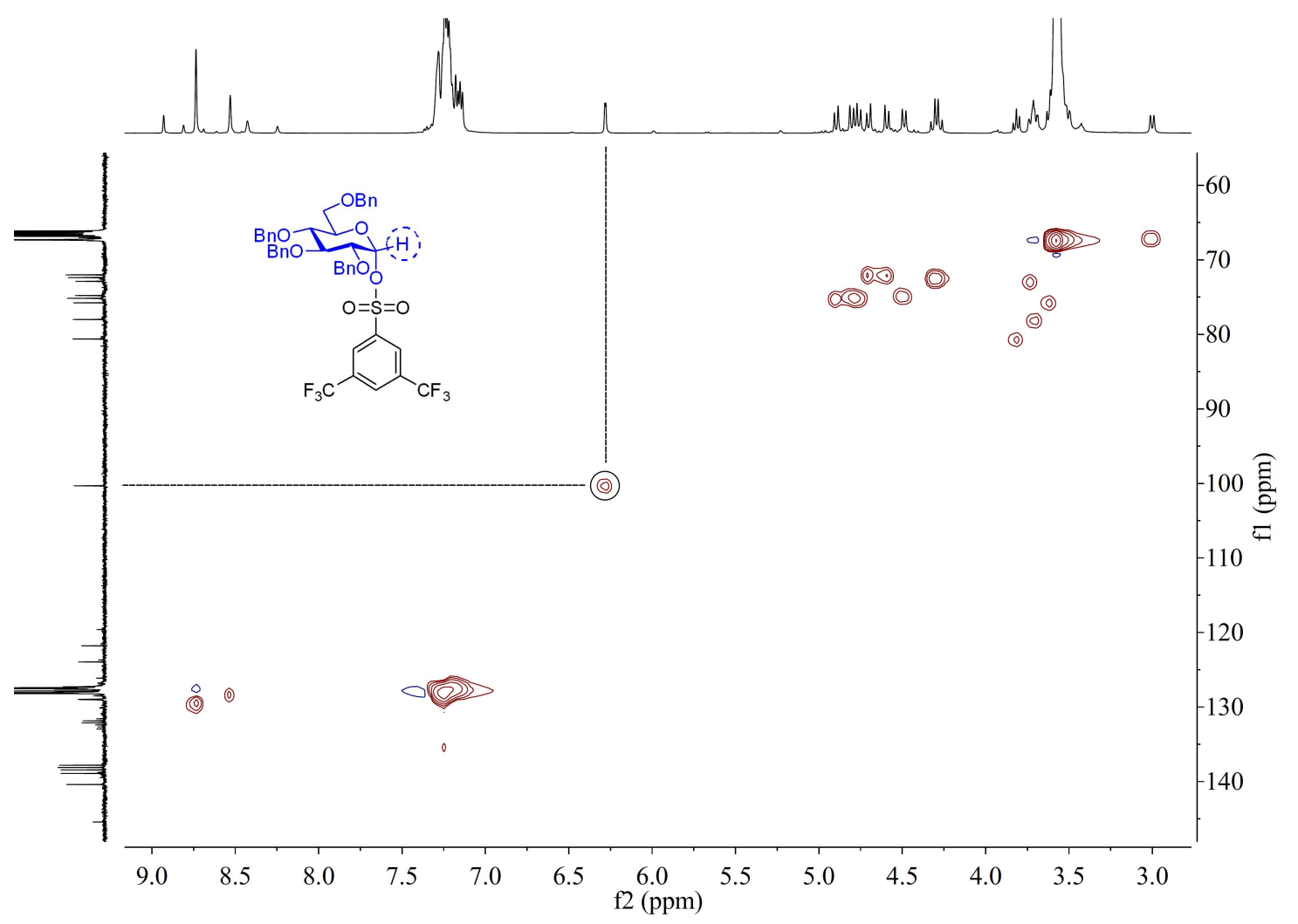

(b)

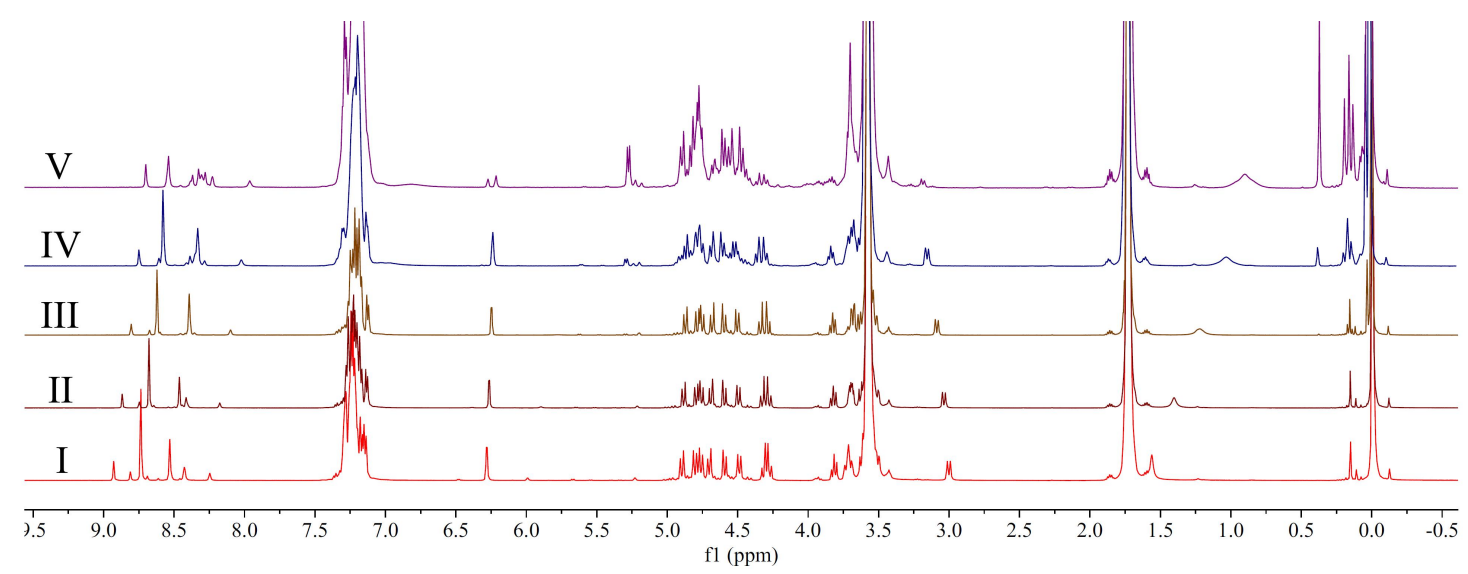

Figure S2. VT-NMR mechanistic studies. (a) 2D Gradient HSQC NMR spectrum of $\alpha$ glucosyl 3,5-bis(trifluoromethyl)-benzenesulfonate at $-60{ }^{\circ} \mathrm{C}$. (b) ${ }^{1} \mathrm{H}$ NMR spectra to evaluate the stability of the $\alpha$-glucosyl 3,5-bis(trifluoromethyl)-benzenesulfonate in THF-d 8 at: (I) $-60{ }^{\circ} \mathrm{C}$, (II) $-40{ }^{\circ} \mathrm{C}$, (III) $-20^{\circ} \mathrm{C}$, (IV) $0{ }^{\circ} \mathrm{C}$, (V) $25^{\circ} \mathrm{C}$ 


\subsection{Activated sulfonate donor for elimination reaction test}

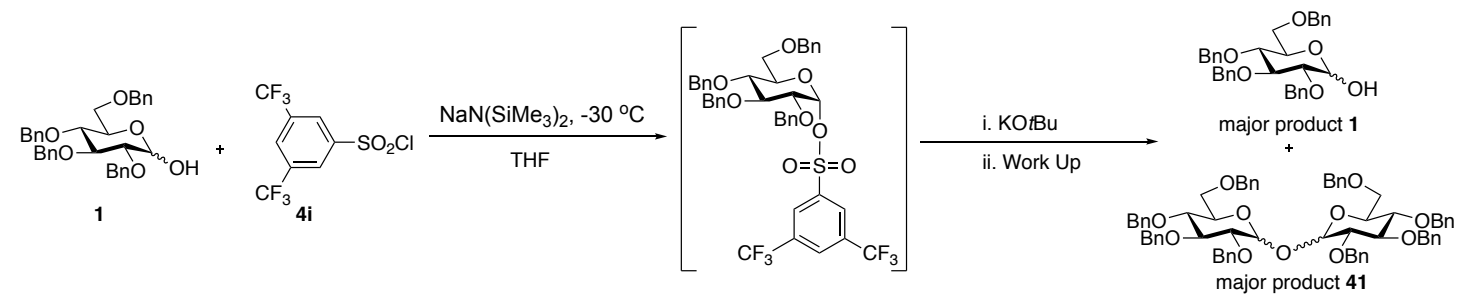

A solution of donor $1(0.1080 \mathrm{~g}, 0.2 \mathrm{mmol}, 1$ equiv. $)$ in $1.0 \mathrm{~mL}$ of THF was cooled to $30{ }^{\circ} \mathrm{C}$ and treated with sodium hexamethyldisilazane $(1 \mathrm{M}$ in THF, $0.2 \mathrm{~mL}, 0.2 \mathrm{mmol}$, 1 equiv.). After 10 minutes, this solution was transferred by syringe to a flask containing the solution of 3,5-bis(trifluoromethyl)benzenesulfonyl chloride $4 \mathbf{i}(0.0623 \mathrm{~g}, 0.2 \mathrm{mmol}$, 1 equiv.) in $1.0 \mathrm{~mL}$ of THF that had been pre-cooled to $-30^{\circ} \mathrm{C}$. The flask that contained the donor was then rinsed with an additional $0.5 \mathrm{~mL}$ of THF, and this rinse was then added to the donor and sulfonyl chloride reaction mixture. After this mixture has stirred for two hours at $-30{ }^{\circ} \mathrm{C}$, it was treated with potassium tert-butoxide $(0.0224 \mathrm{~g}, 0.2 \mathrm{mmol}$, 1 equiv.). After 4 hrs. The reaction was quenched with $0.2 \mathrm{~mL}$ of saturated aqueous ammonium chloride $\left(\mathrm{NH}_{4} \mathrm{Cl}\right)$, diluted with water, and extracted with diethyl ether $(4 \mathrm{x}$ $10 \mathrm{~mL})$. The combined organic phase was washed with brine $(20 \mathrm{~mL})$ and then dried $\left(\mathrm{Na}_{2} \mathrm{SO}_{4}\right)$. An aliquot of $(1.0 \mathrm{~mL})$ of this solution was removed for NMR and LCMS analysis. The E2 elimination product was not found in the crude ${ }^{1} \mathrm{H}$ NMR and LCMS according to the literature. ${ }^{[23]}$

(Potassium tert-butoxide was prepared by heating at $150-160^{\circ} \mathrm{C} / 2 \mathrm{~mm}$ for $1 \mathrm{~h}$ to remove the tert-BuOH according to the literature method. ${ }^{[24]}$ ) 
(a) ${ }^{1} \mathrm{H} \mathrm{NMR}\left(500 \mathrm{MHz}, \mathrm{CDCl}_{3}\right)$

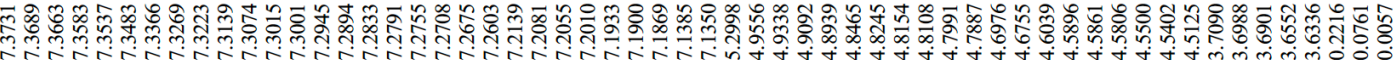

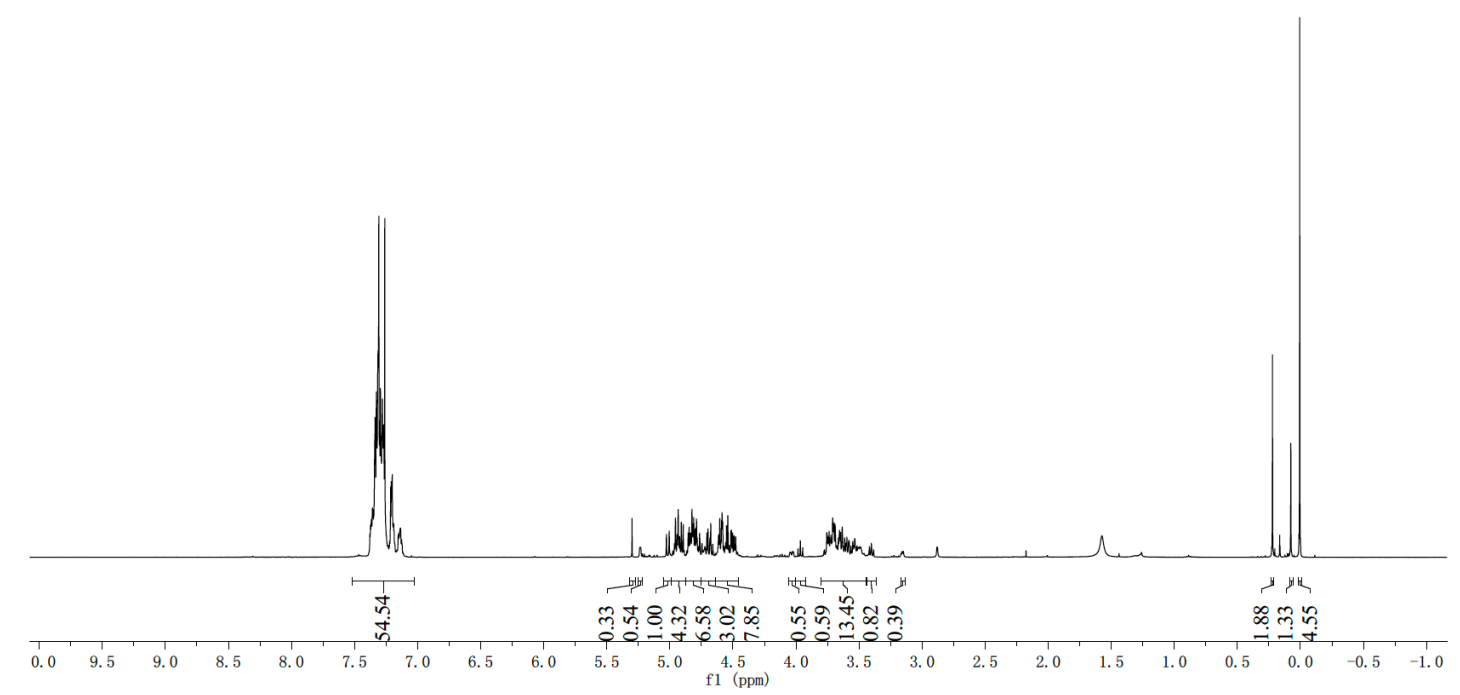

(b)
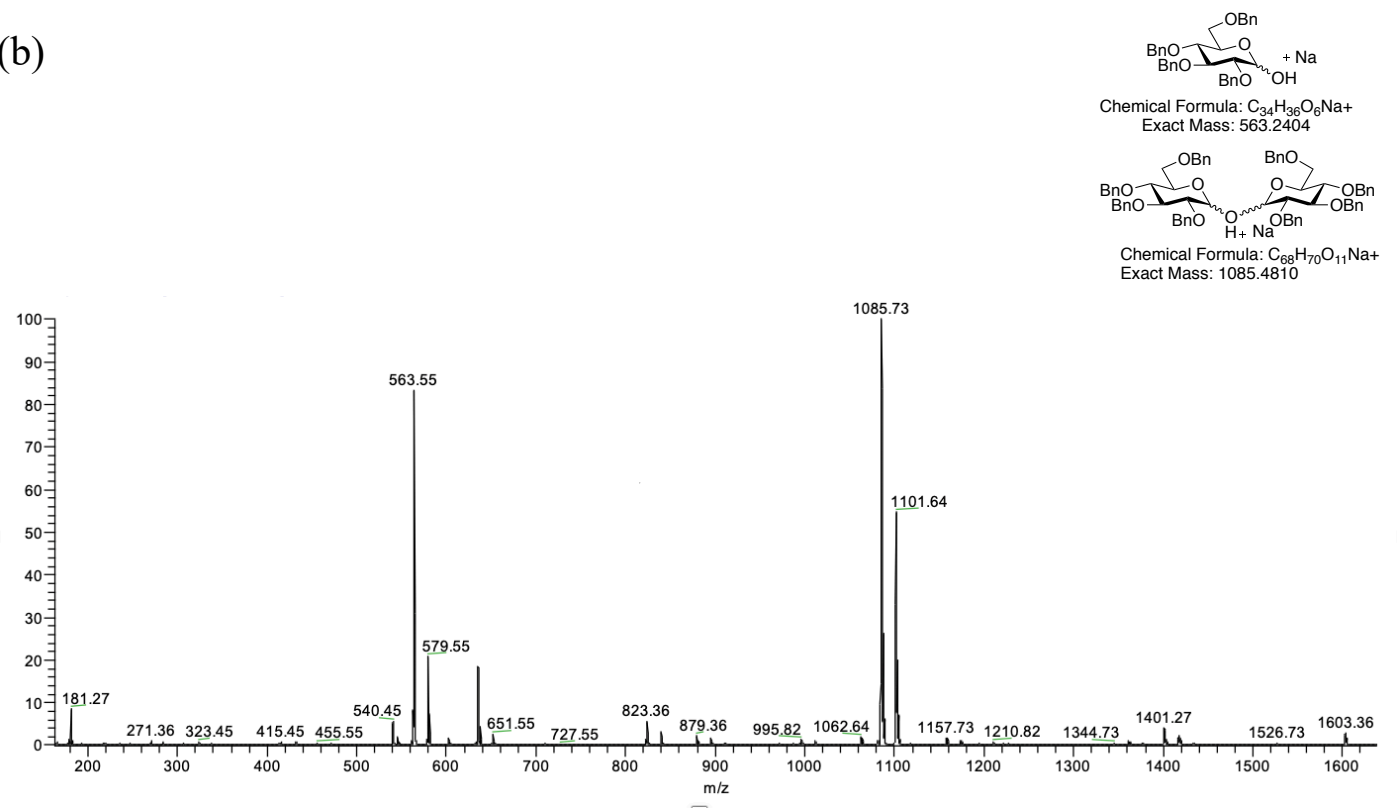

Figure S3. (a) the ${ }^{1} \mathrm{H}$ NMR for the aliquot of reaction in $\mathrm{CDCl}_{3}$; (b) the $\mathrm{LCMS}$ for the aliquot. 


\section{KIE Measurements}

\section{$5.1{ }^{13} \mathrm{C}$ KIE measurements}
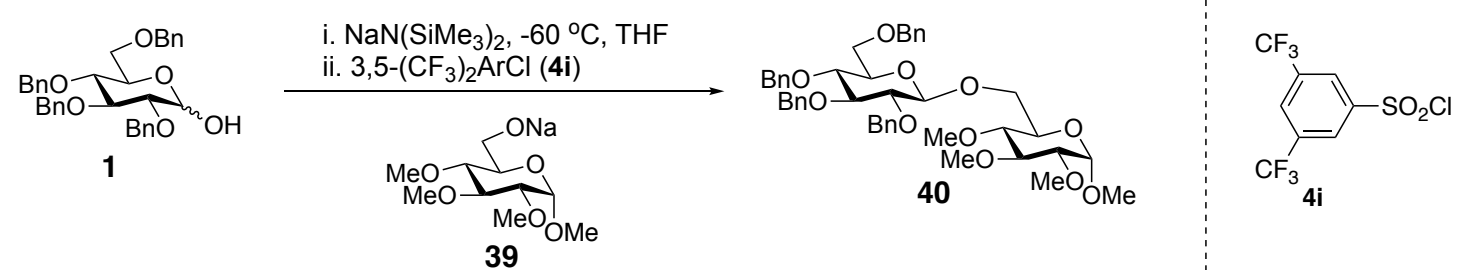

Procedure for the glycosylation of perbenzylated glucosyl donor 1 with permethylated acceptor 39.

\section{High conversion:}

A solution of donor 1 ( $0.2701 \mathrm{~g}, 0.5 \mathrm{mmol}, 1$ equiv.) in $2.5 \mathrm{~mL}$ of THF was cooled to $-60{ }^{\circ} \mathrm{C}$ and treated with sodium hexamethyldisilazane $(1 \mathrm{M}$ in THF, $0.5 \mathrm{~mL}, 0.5 \mathrm{mmol}$, 1 equiv.). After 10 minutes, this solution was transferred by syringe to a flask containing the solution of 3,5-bis(trifluoromethyl)benzenesulfonyl chloride $4 \mathbf{i}(0.1559 \mathrm{~g}, 0.5$ mmol, 1 equiv.) in $2.5 \mathrm{~mL}$ of THF that had been pre-cooled to $-60{ }^{\circ} \mathrm{C}$. The flask that contained the donor was then rinsed with an additional $1.3 \mathrm{~mL}$ of THF, and this rinse was then added to the donor and sulfonyl chloride reaction mixture. After this mixture has stirred for two hours at $-60^{\circ} \mathrm{C}$, it was treated with a freshly prepared solution of the alkoxide acceptor (prepared by treating a solution of acceptor $39(0.2361 \mathrm{~g}, 1.0 \mathrm{mmol}$, 2 equiv.) in $4.0 \mathrm{~mL}$ of THF at $-60{ }^{\circ} \mathrm{C}$ with sodium hexamethyldisilazane (1.0 mL, 1.0 mmol, 2 equiv.). and stirring for 10 minutes.). The flask that contained the acceptor was rinsed with $2.0 \mathrm{~mL}$ of THF, and this rinse was then added to the glycosylation reaction. After 6 hours, the reaction was quenched with $0.5 \mathrm{~mL}$ of saturated aqueous ammonium chloride $\left(\mathrm{NH}_{4} \mathrm{Cl}\right)$, diluted with water, and extracted with diethyl ether $(4 \mathrm{x} 15 \mathrm{~mL})$. The combined organic phase was washed with brine $(60 \mathrm{~mL})$ and then dried $\left(\mathrm{Na}_{2} \mathrm{SO}_{4}\right)$. Internal standard 1-bromo-2,4,6-tri-tert-butylbenzene was added to the crude sample. An aliquot of $0.4 \mathrm{~mL}$ was removed for NMR analysis. The rest of the crude product was purified by silica gel flash column chromatography (30\% ethyl acetate in hexane) to afford disaccharide $\mathbf{4 0}$ exclusively as the $\beta$-isomer $(0.3443 \mathrm{~g}, 0.454 \mathrm{mmol}, 91 \%$ yield relative to donor $\mathbf{1})$. This reaction was conducted twice. The second time, the yield of this reaction was $90 \%$ relative to donor 1 .

\section{Partial conversion:}

A solution of donor $1(0.6483 \mathrm{~g}, 1.2 \mathrm{mmol}, 4$ equiv. $)$ in $6.0 \mathrm{~mL}$ of THF was cooled to $-60{ }^{\circ} \mathrm{C}$ and treated with sodium hexamethyldisilazane (1 M in THF, $1.2 \mathrm{~mL}, 1.2 \mathrm{mmol}$, 4 equiv.). After 10 minutes, this solution was transferred by syringe to a flask containing 
the solution of 3,5-bis(trifluoromethyl)benzenesulfonyl chloride $4 \mathbf{i}(0.3743 \mathrm{~g}, 1.2 \mathrm{mmol}$, 4 equiv.) in $6.0 \mathrm{~mL}$ of THF that had been pre-cooled to $-60^{\circ} \mathrm{C}$. The flask that contained the donor was then rinsed with an additional $3.0 \mathrm{~mL}$ of THF, and this rinse was then added to the donor and sulfonyl chloride reaction mixture. After this mixture has stirred for two hours at $-60{ }^{\circ} \mathrm{C}$, it was treated with a freshly prepared solution of the alkoxide acceptor (prepared by treating a solution of acceptor 39 (0.0708 g, $0.3 \mathrm{mmol}, 1$ equiv.) in $1.5 \mathrm{~mL}$ of $\mathrm{THF}$ at $-60^{\circ} \mathrm{C}$ with sodium hexamethyldisilazane $(0.3 \mathrm{~mL}, 0.3 \mathrm{mmol}, 1$ equiv.). and stirring for 10 minutes.). The flask that contained the acceptor was rinsed with $1.5 \mathrm{~mL}$ of THF, and this rinse was then added to the glycosylation reaction. After 2 hours, the reaction was quenched with $1.2 \mathrm{~mL}$ of saturated aqueous ammonium chloride $\left(\mathrm{NH}_{4} \mathrm{Cl}\right)$, diluted with water, and extracted with diethyl ether $(4 \times 20 \mathrm{~mL})$. The combined organic phase was washed with brine $(80 \mathrm{~mL})$ and then dried $\left(\mathrm{Na}_{2} \mathrm{SO}_{4}\right)$. Internal standard 1-bromo-2,4,6-tri-tert-butylbenzene was added to the crude sample. An aliquot of $1.0 \mathrm{~mL}$ was removed for NMR analysis. The rest of the crude product was purified by silica gel flash column chromatography (30\% ethyl acetate in hexane) to afford disaccharide $\mathbf{4 0}$ exclusively as the $\beta$-isomer $(0.2041 \mathrm{~g}, 0.269 \mathrm{mmol}, 22 \%$ yield relative to donor $\mathbf{1}$ ). This reaction was conducted twice. The second time, the yield of this reaction was $23 \%$ relative to donor 1 .

Note: spectra for ${ }^{13} \mathrm{C}$ KIE studies were taken in 2.3:1 $\mathrm{CDCl}_{3}: \mathrm{C}_{6} \mathrm{D}_{6}$ to avoid peak overlap at the $\mathrm{C} 5$ resonance of the donor. The samples for ${ }^{13} \mathrm{C}$ KIE studies were prepared by dissolving $150 \mathrm{mg}$ of $\mathbf{4 0}$ in $0.6 \mathrm{~mL}$ of $2.3: 1 \mathrm{CDCl}_{3}: \mathrm{C}_{6} \mathrm{D}_{6}$ with $0.5 \mathrm{mM}$ of $\mathrm{Cr}(\mathrm{acac})_{3}$ as a relaxation reagent.

Tables S6-S8 of Integrals for ${ }^{13} \mathrm{C}$ KIE Measurements

Table S6.

\begin{tabular}{|l|l|l|l|l|l|l|}
\hline sample name (raw integral) & C1 & C2 & C3 & C4 & C5 & blocks* \\
\hline sample 1 (full conversion 1) & 11.2474 & 10.2324 & 10.3012 & 10.3829 & 10.1132 & 200 \\
\hline sample 2 (full conversion 2) & 10.6913 & 9.7816 & 9.8166 & 9.9089 & 9.6774 & 174 \\
\hline sample 3 (partial conversion 1) & 10.8754 & 10.1588 & 10.2488 & 10.325 & 10.109 & 199 \\
\hline sample 4 (partial conversion 2) & 10.2786 & 9.6152 & 9.7069 & 9.7771 & 9.5636 & 200 \\
\hline
\end{tabular}

* each block corresponds to 32 scans

Table S7.

\begin{tabular}{|l|l|l|l|l|l|}
\hline sample name (standard deviation) & C1 & C2 & C3 & C4 & C5 \\
\hline sample 1 (full conversion 1) & 0.2473 & 0.2308 & 0.2364 & 0.2253 & 0.2206 \\
\hline sample 2 (full conversion 2) & 0.2600 & 0.2205 & 0.2349 & 0.2363 & 0.2330 \\
\hline sample 3 (partial conversion 1) & 0.2532 & 0.2168 & 0.2492 & 0.2201 & 0.2603 \\
\hline sample 4 (partial conversion 2) & 0.2710 & 0.2208 & 0.2013 & 0.2073 & 0.2002 \\
\hline
\end{tabular}


Table S8.

\begin{tabular}{|l|l|l|l|l|l|}
\hline ratios $\left({ }^{\mathbf{1 3}} \mathbf{C} /{ }^{\mathbf{1}} \mathbf{C}\right)$ & $\mathbf{C 1}$ & $\mathbf{C 2}$ & $\mathbf{C 3}$ & $\mathbf{C 4}$ & $\mathbf{C 5}$ \\
\hline sample 1 (full conversion 1) & 1.0919 & 0.9933 & 1.0000 & 1.0079 & 0.9817 \\
\hline sample 2 (full conversion 2) & 1.0891 & 0.9964 & 1.0000 & 1.0094 & 0.9858 \\
\hline sample 3 (partial conversion 1) & 1.0611 & 0.9912 & 1.0000 & 1.0074 & 0.9864 \\
\hline sample 4 (partial conversion 2) & 1.0589 & 0.9906 & 1.0000 & 1.0072 & 0.9852 \\
\hline
\end{tabular}

Table S9.

\begin{tabular}{|l|l|l|l|l|}
\hline experimental KIEs & C1 & C2 & C4 & C5 \\
\hline measurement 1 & $1.032(4)$ & $1.004(4)$ & $1.001(4)$ & $0.997(4)$ \\
\hline measurement 2 & $1.035(4)$ & $1.005(4)$ & $1.002(4)$ & $0.998(4)$ \\
\hline
\end{tabular}

\section{$5.2 \alpha$-SDKIE measurements}

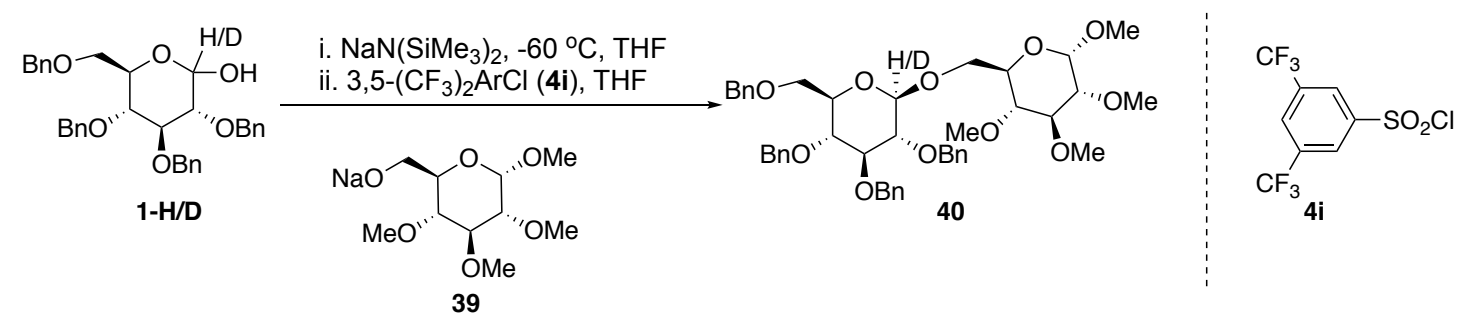

To gain further insight into the mechanism of the glycosylation reactions, secondary H/D KIE measurements were conducted. The KIE was calculated according to:

$\mathrm{KIE}=\ln (1-\mathrm{F}) / \ln \left[1-\left(\mathrm{FR}_{\mathrm{p}} / \mathrm{R}_{0}\right)\right]$

where $\mathrm{F}$ is the fractional conversion of the $\alpha$-sulfonate (yield of $\mathbf{4 0}$ ), $\mathrm{R}_{0}$ is the ratio of heavy to light isotopologues in starting material, and $\mathrm{R}_{\mathrm{p}}$ is the ratio of heavy to light isotopologues in product. The quantity of heavy isotopologue was calculated by subtracting the NMR integral of the anomeric peak from that of a reference peak. (Two reference peaks were considered and their integrals were found to be within $0.5 \%$ of one another. The average of the two reference integrals was taken as the overall reference.)

$\mathrm{R}=[$ heavy $] /[$ light $]$

$\mathrm{R}=[($ integral of reference $1+$ integral of reference 2$) / 2$ - integral of anomeric peak $] /$ integral of anomeric peak

Three independent $\alpha$-SDKIE measurements were made. For each of the three pairs of spectra, $\mathrm{R}_{0}$ was determined by integrating the spectrum of the full conversion sample, 
while $R_{p}$ was determined by integrating the spectrum of the partial conversion sample. This method ensures minimizes errors, since the same peaks and integration ranges are used for all measurements. To further improve consistency, the NMR samples were prepared with the same concentration.

The NMR spectra were recorded on a Bruker Avance III NMR spectrometer at 500 $\mathrm{MHz}$ for ${ }^{1} \mathrm{H}$ NMR. The relaxation delay was set to $60 \mathrm{~s}$. Each ${ }^{1} \mathrm{H}$ spectrum was acquired with a $5.5 \mathrm{ppm}$ sweep width and 4 scans. The NMR data was processed using MestReNova version 6.1. The baseline was corrected to remove the baseline distortions that are associated with ${ }^{1} \mathrm{H}$ NMR using the Whittaker Smoother method found in MestReNova.

\section{Partial conversion:}

Donor 1-H/D (prepared by mixing an approximately equal quantity of the nondeuterated material to deuterated material; total $0.2161 \mathrm{~g}, 0.4 \mathrm{mmol}$ ) was dissolved in $2.0 \mathrm{~mL}$ of THF. A portion $(0.2 \mathrm{~mL})$ of this solution was used for the full conversion reaction. The remaining donor solution was cooled to $-60{ }^{\circ} \mathrm{C}$ and treated with sodium hexamethyldisilazane ( $1 \mathrm{M}$ in THF, $0.36 \mathrm{~mL}, 0.36 \mathrm{mmol})$. After 10 minutes, this solution was transferred by syringe to a flask containing the solution of 3,5bis(trifluoromethyl)benzenesulfonyl chloride $4 \mathbf{i}(0.1123 \mathrm{~g}, 0.36 \mathrm{mmol}, 4$ equiv.) in 1.8 $\mathrm{mL}$ of THF that had been pre-cooled to $-60{ }^{\circ} \mathrm{C}$. The flask that contained the donor was rinsed with an additional $0.9 \mathrm{~mL}$ of THF, and this rinse was then added to the donor and sulfonyl chloride reaction mixture. After this mixture has stirred for two hours at $60{ }^{\circ} \mathrm{C}$, it was treated with a freshly prepared solution of the alkoxide acceptor (prepared by treating a solution of acceptor $39(0.0213 \mathrm{~g}, 0.09 \mathrm{mmol}, 1$ equiv. $)$ in $0.5 \mathrm{~mL}$ of THF at $-60{ }^{\circ} \mathrm{C}$ with sodium hexamethyldisilazane $(0.09 \mathrm{~mL}, 0.09 \mathrm{mmol}, 1$ equiv.) and stirring for 10 minutes). The flask that contained the acceptor was rinsed with $0.5 \mathrm{~mL}$ of THF, and this rinse was then added to the glycosylation reaction. After 2 hours, the reaction was quenched with $0.1 \mathrm{~mL}$ of saturated aqueous ammonium chloride $\left(\mathrm{NH}_{4} \mathrm{Cl}\right)$, diluted with water, and extracted with diethyl ether $(4 \times 15 \mathrm{~mL})$. The combined organic phase was washed with brine $(30 \mathrm{~mL})$ and then dried $\left(\mathrm{Na}_{2} \mathrm{SO}_{4}\right)$. The internal standard 1-bromo-2,4,6-tri-tert-butylbenzene $(0.09 \mathrm{mmol})$ was added to the solution containing the crude sample. An aliquot $(1.0 \mathrm{~mL})$ of this solution was removed for NMR analysis. The remaining solution was concentrated, and the crude product was purified by silica gel flash column chromatography (30\% ethyl acetate in hexane) to afford disaccharide 40 exclusively as the $\beta$-isomer. $\mathrm{R}_{\mathrm{p}}$ was measured by ${ }^{1} \mathrm{H}$ NMR $(15.8 \mathrm{mM}$ of disaccharide 40 in $\mathrm{CD}_{2} \mathrm{Cl}_{2}, \mathrm{~ns}=4, \mathrm{~d} 1=60 \mathrm{~s}$ ). 


\section{Full conversion:}

The portion $(0.2 \mathrm{~mL})$ of the above donor solution was cooled to $-60{ }^{\circ} \mathrm{C}$ and treated with sodium hexamethyldisilazane ( $1 \mathrm{M}$ in THF, $0.04 \mathrm{~mL}, 0.04 \mathrm{mmol})$. After 10 minutes, this solution was transferred by syringe to a flask containing the solution of 3,5bis(trifluoromethyl)benzenesulfonyl chloride $4 \mathbf{i}(0.0125 \mathrm{~g}, 0.04 \mathrm{mmol}, 1$ equiv.) in 0.2 $\mathrm{mL}$ of THF that had been pre-cooled to $-60^{\circ} \mathrm{C}$. The flask that contained the donor was rinsed with an additional $0.2 \mathrm{~mL}$ of THF, and this rinse was then added to the donor and sulfonyl chloride reaction mixture. After this reaction mixture has stirred for two hours at $-60^{\circ} \mathrm{C}$, it was treated with a freshly prepared solution of the alkoxide acceptor (prepared by treating a solution of acceptor $39(0.0378 \mathrm{~g}, 0.16 \mathrm{mmol}, 4$ equiv.) in 0.8 $\mathrm{mL}$ of THF at $-60^{\circ} \mathrm{C}$ with sodium hexamethyldisilazane $(0.16 \mathrm{~mL}, 0.16 \mathrm{mmol}, 4$ equiv. $)$ and stirring for 10 minutes.). The flask that contained the acceptor was rinsed with 0.4 $\mathrm{mL}$ of THF, and this rinse was then added to the glycosylation reaction. After 6 hours, the reaction was quenched with $0.01 \mathrm{~mL}$ of saturated aqueous ammonium chloride $\left(\mathrm{NH}_{4} \mathrm{Cl}\right)$, diluted with water, and extracted with diethyl ether $(4 \times 5 \mathrm{~mL})$. The combined organic phase was washed with brine $(10 \mathrm{~mL})$ and then dried $\left(\mathrm{Na}_{2} \mathrm{SO}_{4}\right)$. An internal standard 1-bromo-2,4,6-tri-tert-butylbenzene $(0.04 \mathrm{mmol})$ was added to the solution containing the crude sample. An aliquot of $1.0 \mathrm{~mL}$ was removed for NMR analysis. The rest of the solution was concentrated, and the crude product was purified by silica gel flash column chromatography (30\% ethyl acetate in hexane) to afford disaccharide 40 exclusively as the $\beta$-isomer. $\mathrm{R}_{0}$ was measured by ${ }^{1} \mathrm{H}$ NMR (15.8 $\mathrm{mM}$ of disaccharide 40 in $\mathrm{CD}_{2} \mathrm{Cl}_{2}$, ns $=4, \mathrm{~d} 1=60 \mathrm{~s}$ ).

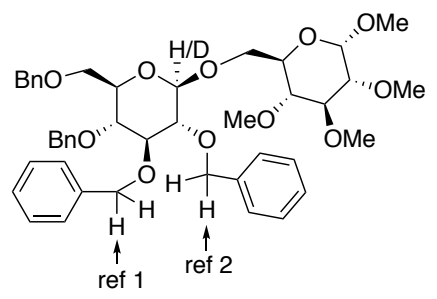

structure of $\mathbf{4 0}$

Reference peak 1 (ref 1):

The region from $4.954 \mathrm{ppm}$ to $4.897 \mathrm{ppm}$ in the ${ }^{1} \mathrm{H} \mathrm{NMR}$ spectrum $\left(\mathrm{CD}_{2} \mathrm{Cl}_{2}\right)$ was taken as reference peak 1 . This peak corresponds to one of the diastereotopic methylene protons of the benzyl group attached to the $\mathrm{C} 3$ position of the donor in product $\mathbf{4 0}$.

Reference peak 2 (ref 2$)$ : 
The region from $5.074 \mathrm{ppm}$ to $4.988 \mathrm{ppm}$ in the ${ }^{1} \mathrm{H}$ NMR spectrum $\left(\mathrm{CD}_{2} \mathrm{Cl}_{2}\right)$ was taken as reference peak 2. This peak corresponds to one of the diastereotopic methylene protons of the benzyl group attached to the $\mathrm{C} 2$ position of the donor in product $\mathbf{4 0}$.

Anomeric peak:

The region from $4.519 \mathrm{ppm}$ to $4.468 \mathrm{ppm}$ in the ${ }^{1} \mathrm{H}$ NMR spectrum $\left(\mathrm{CD}_{2} \mathrm{Cl}_{2}\right)$ was taken as the anomeric peak.

Table S10. NMR integral and calculation of $\mathrm{R}_{0}$ and $\mathrm{R}_{\mathrm{p}}$ for $\alpha-\mathrm{SKIE}$

\begin{tabular}{c|c|c|c|c|c|c|c|c}
\hline & \multicolumn{4}{|c|}{ full conversion } & \multicolumn{3}{c}{ partial conversion } \\
\hline \multirow{2}{*}{ run } & $\begin{array}{c}\text { integral of } \\
\text { anomeric } \\
\text { peak }\end{array}$ & $\begin{array}{c}\text { integral } \\
\text { of ref 1 }\end{array}$ & $\begin{array}{c}\text { integral } \\
\text { of ref 2 }\end{array}$ & $\mathrm{R}_{0}$ & $\begin{array}{c}\text { integral of } \\
\text { anomeric } \\
\text { peak }\end{array}$ & $\begin{array}{c}\text { integral } \\
\text { of ref 1 }\end{array}$ & $\begin{array}{c}\text { integral } \\
\text { of ref 2 }\end{array}$ & $\mathrm{R}_{\mathrm{p}}$ \\
\hline $\begin{array}{c}\text { integration } \\
\text { range } \\
(\mathrm{ppm})\end{array}$ & $\begin{array}{c}4.519- \\
4.468\end{array}$ & $\begin{array}{c}4.954- \\
4.897\end{array}$ & $\begin{array}{c}5.074- \\
4.988\end{array}$ & & $\begin{array}{c}4.519- \\
4.468\end{array}$ & $\begin{array}{c}4.954- \\
4.897\end{array}$ & $\begin{array}{c}5.074- \\
4.988\end{array}$ & \\
\hline 2 & 51.09 & 99.71 & 100.00 & 0.9545 & 54.52 & 99.80 & 100.00 & 0.8324 \\
\hline 3 & 52.14 & 99.60 & 100.00 & 0.9141 & 55.56 & 100.26 & 100.00 & 0.8022 \\
\hline
\end{tabular}

Table S11. Summary of $\alpha$-SKIE

\begin{tabular}{lllllll}
\hline run & $\mathrm{F}$ & $\ln (1-\mathrm{F})$ & $\mathrm{R}_{0}$ & $\mathrm{R}_{\mathrm{p}}$ & $\ln \left[1-\left(\mathrm{FR}_{\mathrm{p}} / \mathrm{R}_{0}\right)\right]$ & $\alpha-\mathrm{SDKIE}$ \\
\hline 1 & 0.235 & -0.2679 & 0.9545 & 0.8324 & -0.2293 & 1.17 \\
2 & 0.235 & -0.2679 & 0.9425 & 0.8309 & -0.2322 & 1.15 \\
3 & 0.245 & -0.2810 & 0.9140 & 0.8022 & -0.2421 & 1.16 \\
average & & & & & & 1.16 \\
\hline
\end{tabular}


full conversion (product $40{ }^{1} \mathrm{H}$ NMR in $\mathrm{CD}_{2} \mathrm{Cl}_{2}, 500 \mathrm{MHz}$ )

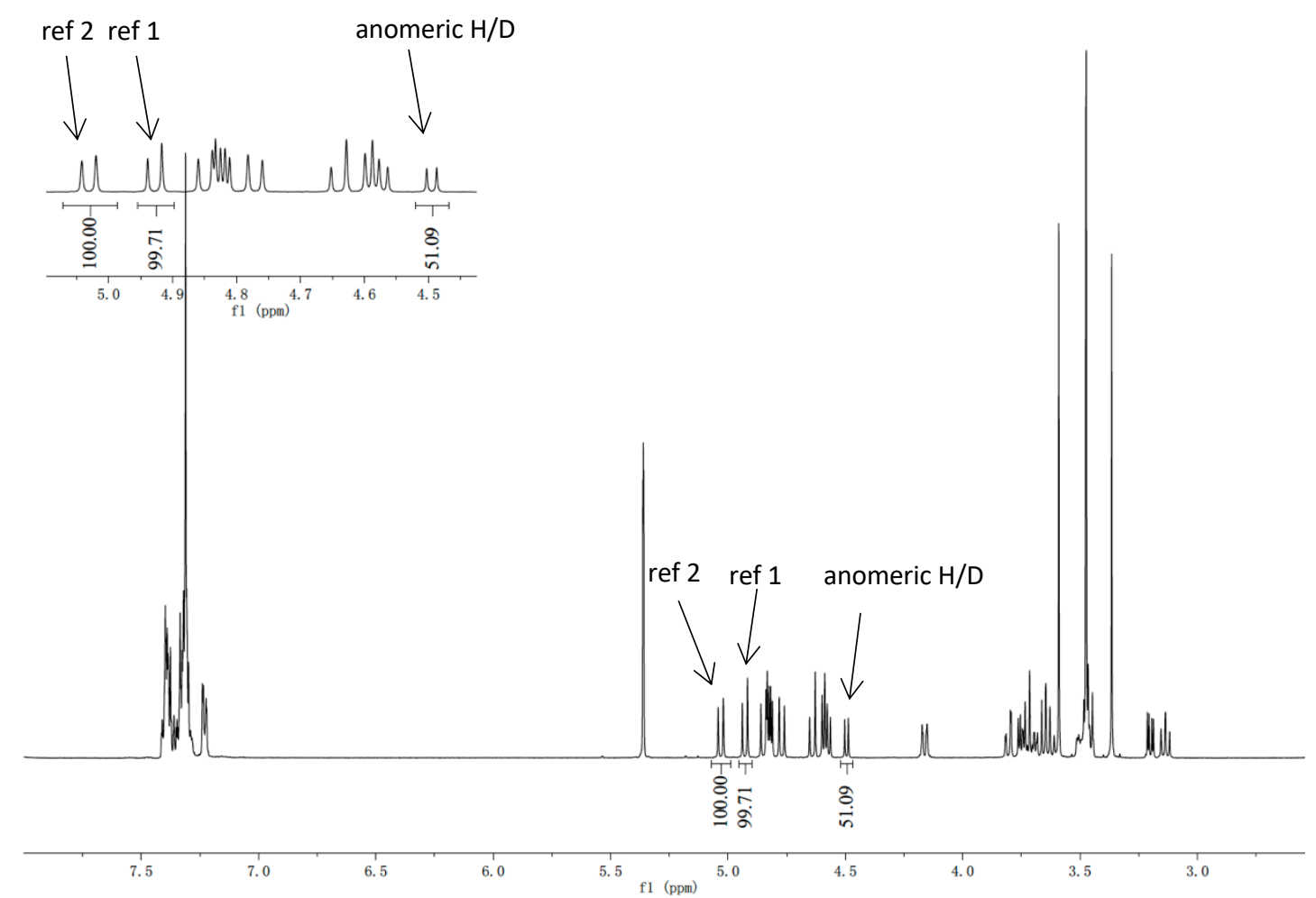

partial conversion (product $40{ }^{1} \mathrm{H} \mathrm{NMR}$ in $\mathrm{CD}_{2} \mathrm{Cl}_{2}, 500 \mathrm{MHz}$ )

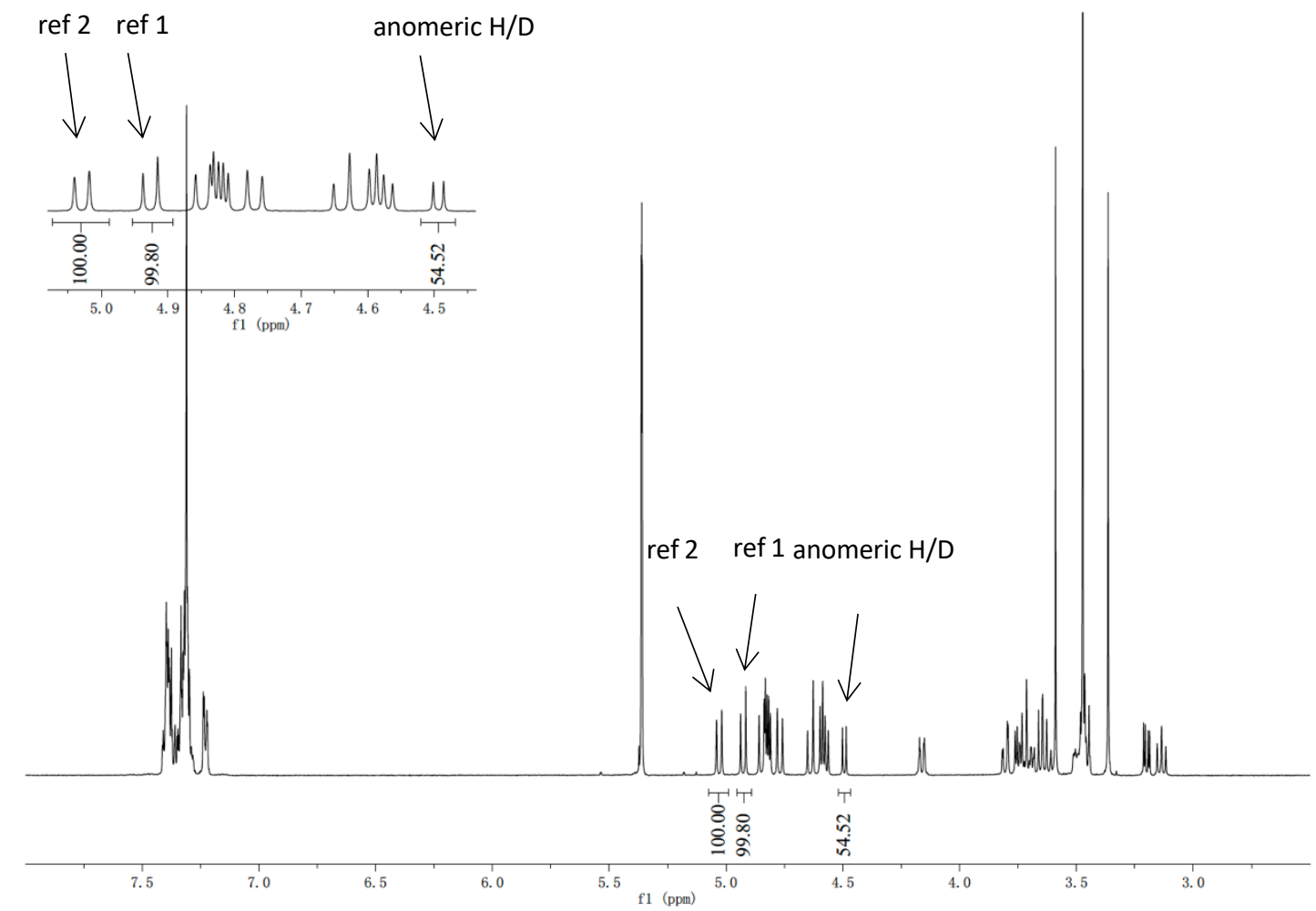

Figure S4. One set of ${ }^{1} \mathrm{H}$ NMR spectra of product $\mathbf{4 0}$ (one full conversion sample and one partial conversion sample). 


\subsection{Detailed characterization of disaccharide 40}

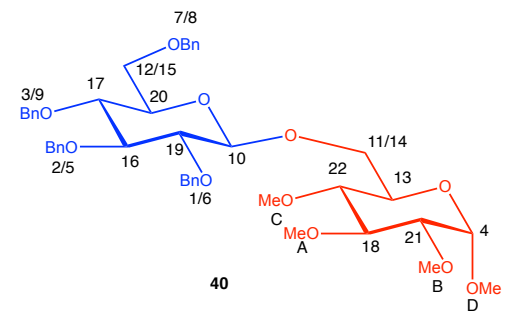

Spectra were taken by $20 \mathrm{mg}$ of disaccharide $\mathbf{4 0}$ in $\mathrm{CDCl}_{3}$. Aryl peaks are not given. (Donor on left and acceptor on right)

Table S12. Characterization of disaccharide $\mathbf{4 0}$

\begin{tabular}{|c|c|c|c|}
\hline$\#$ & ${ }^{1} \mathbf{H}(\mathbf{p p m})$ & ${ }^{13} \mathrm{C}$ (ppm) & Notes $\left({ }^{1} \mathbf{J}_{\mathbf{C H}}\right)$ \\
\hline 1 & 5.01 & 74.87 & \\
\hline 2 & 4.91 & 75.72 & \\
\hline 3 & 4.82 & 75.02 & \\
\hline 4 & 4.81 & 97.35 & acceptor anomeric $(170 \mathrm{~Hz})$ \\
\hline 5 & 4.78 & 75.72 & \\
\hline 6 & 4.75 & 74.87 & \\
\hline 7 & 4.59 & 73.44 & \\
\hline 8 & 4.59 & 73.44 & \\
\hline 9 & 4.55 & 75.02 & \\
\hline 10 & 4.47 & 103.90 & donor anomeric $(159 \mathrm{~Hz})$ \\
\hline 11 & 4.19 & 68.83 & \\
\hline 12 & 3.76 & 69.08 & donor C6 $(142 \mathrm{~Hz})$ \\
\hline 13 & 3.72 & 69.85 & \\
\hline 14 & 3.71 & 68.83 & \\
\hline 15 & 3.70 & 69.08 & donor C6 $(142 \mathrm{~Hz})$ \\
\hline 16 & 3.66 & 84.83 & donor C3 $(140 \mathrm{~Hz})$ \\
\hline 17 & 3.58 & 77.97 & donor C4 $(145 \mathrm{~Hz})$ \\
\hline 18 & 3.52 & 83.48 & \\
\hline 19 & 3.51 & 82.19 & donor C2 $(144 \mathrm{~Hz})$ \\
\hline 20 & 3.50 & 75.09 & donor C5 $(137 \mathrm{~Hz})$ \\
\hline 21 & 3.20 & 81.80 & \\
\hline 22 & 3.13 & 79.83 & \\
\hline A & 3.62 & 60.81 & \\
\hline $\mathrm{B}$ & 3.50 & 60.40 & \\
\hline $\mathrm{C}$ & 3.47 & 58.94 & \\
\hline $\mathrm{D}$ & 3.36 & 55.18 & \\
\hline
\end{tabular}




\section{DFT Calculation Procedures and Data}

\subsection{General procedures}

DFT calculations were carried out using Gaussian 16, Revision A.03:

M. J. Frisch, G. W. Trucks, H. B. Schlegel, G. E. Scuseria, M. A. Robb, J. R. Cheeseman, G. Scalmani, V. Barone, G. A. Petersson, H. Nakatsuji, X. Li, M. Caricato, A. V. Marenich, J. Bloino, B. G. Janesko, R. Gomperts, B. Mennucci, H. P. Hratchian, J. V. Ortiz, A. F. Izmaylov, J. L. Sonnenberg, D. Williams-Young, F. Ding, F. Lipparini, F. Egidi, J. Goings, B. Peng, A. Petrone, T. Henderson, D. Ranasinghe, V. G. Zakrzewski, J. Gao, N. Rega, G. Zheng, W. Liang, M. Hada, M. Ehara, K. Toyota, R. Fukuda, J. Hasegawa, M. Ishida, T. Nakajima, Y. Honda, O. Kitao, H. Nakai, T. Vreven, K. Throssell, J. A. Montgomery, Jr., J. E. Peralta, F. Ogliaro, M. J. Bearpark, J. J. Heyd, E. N. Brothers, K. N. Kudin, V. N. Staroverov, T. A. Keith, R. Kobayashi, J. Normand, K. Raghavachari, A. P. Rendell, J. C. Burant, S. S. Iyengar, J. Tomasi, M. Cossi, J. M. Millam, M. Klene, C. Adamo, R. Cammi, J. W. Ochterski, R. L. Martin, K. Morokuma, O. Farkas, J. B. Foresman, and D. J. Fox, Gaussian, Inc., Wallingford CT, 2016.

All stationary points were verified to be true local minima or first-order saddle points by frequency analysis (298.15 K). The default Gaussian standard state was used.

Kinetic isotope effects were predicted using PyQuiver (www.github.com/ekwan/PyQuiver). 3D renderings were made with CYLview. Graphs and statistical analyses were generated in Python using numpy and matplotlib. Conformational searching was performed with Macromodel.

All key Gaussian output files have been deposited at https://github.com/ekwan/bennett_glycosylation, along with the PyQuiver configuration files that are necessary to reproduce the findings discussed below.

A .zip file containing the $S_{N} 2$ transition structures has been included separately. Files are in plain-text Gaussian input file format. The electronic energy, free energy, and number of imaginary frequencies are included in the title card.

\subsection{Prediction of $S_{N} 1$ isotope effects}

We assumed that the transition state for an $\mathrm{S}_{\mathrm{N}} 1$ reaction resembles its carbocation and estimated equilibrium isotope effects (EIEs) by comparing the aryl sulfonate to its corresponding cation. The predicted EIEs are essentially insensitive to the choice of DFT method. ${ }^{[25]}$ Therefore, B3LYP-D3(BJ)/6-31G*/PCM(THF) was chosen as a "standard" method. However, the predicted EIEs are somewhat sensitive to conformation, as the bond lengths of the cation (and therefore the vibrational energies 
of the cation) depend on the degree to which adjacent bonds are aligned for hyperconjugation. Several hundred candidate conformations for both per-methyl glucose 3,5-bis(trifluoromethyl)sulfonate and per-methyl glucose cation were generated using molecular mechanics (Macromodel, OPLS_2005 force field, gas phase). Each structure was then re-minimized using the above DFT method. The lowest-energy glucose sulfonate conformation was chosen as the ground state reference for all subsequent calculations.
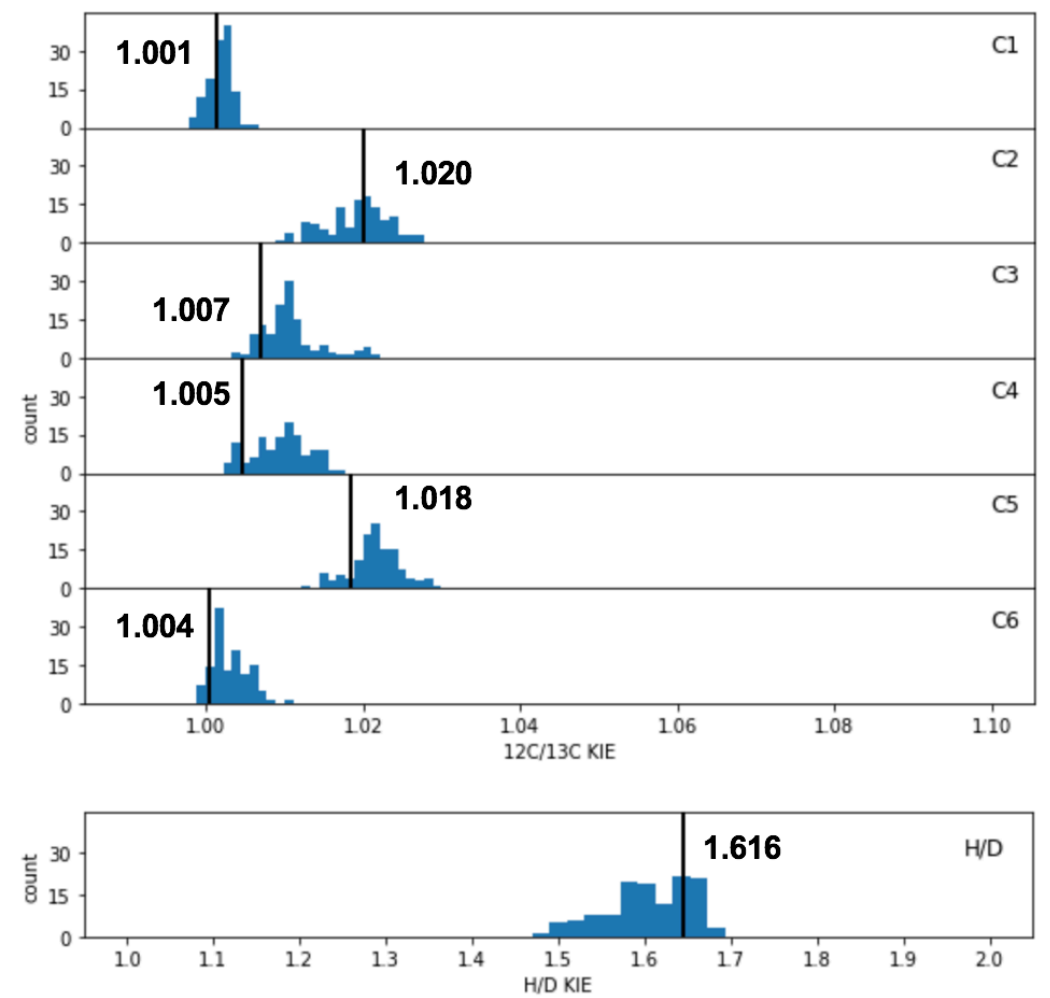

Figure S5. Distribution of predicted EIEs for an $\mathrm{S}_{\mathrm{N}} 1$ process

( $213 \mathrm{~K}$, unscaled frequencies). Black bars and numbers indicate the predicted values for the lowest-energy glucose cation.

We then considered the predicted EIEs for an $\mathrm{S}_{\mathrm{N}} 1$ process. The EIE at $\mathrm{C} 1$ is near unity. This reflects a near-perfect cancellation of two opposing effects: leavinggroup bond heterolysis (normal effect) and hyperconjugative stabilization of the carbocation by all adjacent bonds (inverse effect). This latter hyperconjugative effect is manifested in the significant normal KIEs at C2 and C5, as well as the smaller effects at more remote centers.

The secondary hydrogen/deuterium EIE largely reflects the relative stiffness of the out-of-plane mode between the ground state and the cation. The predicted EIEs range from 1.5-1.7 with a value of 1.62 for the lowest-energy conformation of the cation. This is a relatively large secondary EIE that is consistent with the transition from $\mathrm{sp}^{3}$ to $\mathrm{sp}^{2}$ bonding at $\mathrm{C} 1$. More realistic models of the $\mathrm{S}_{\mathrm{N}} 1$ process would include the leaving group (and possibly the nucleophile). These groups would restrict the motion of $\mathrm{C} 1$, stiffening the out-of-plane mode in the transition state, and therefore 
reduce the expected isotope effect. The experimental isotope effect is far less than the predicted range of values for an $\mathrm{S}_{\mathrm{N}} 1$ process, providing evidence against an oxocarbenium ion.

\subsection{Prediction of $S_{N} 2$ isotope effects}

The relatively large normal KIE experimentally observed at $\mathrm{C} 1$ suggests that the reaction is proceeding through an $\mathrm{S}_{\mathrm{N}} 2$ pathway. Therefore, detailed computational models of many possible $\mathrm{S}_{\mathrm{N}} 2$ transition states were constructed and their predicted KIEs compared to experiment. Once again, B3LYP-D3(BJ)/6-31G* was employed as a standard method. This method has previously been demonstrated ${ }^{[26]}$ to reproduce experimental KIEs for traditional $\mathrm{S}_{\mathrm{N}} 2$ reactions. Solvation was found to be extremely important. A hybrid implicit/explicit solvation model was used in which an explicit sodium counterion for the alkoxide was included, along with one explicit dimethyl ether ligand. The rest of the solvent was represented implicitly with PCM (THF).

There are many possible degrees of freedom in the coupling between two glucose molecules. To reduce the size of the system, all protecting groups were truncated to methyl. (Experimentally, the reaction was performed with methyl protecting groups on the acceptor and benzyl protecting groups on the donor. Performing the reaction with methyl protecting groups on both partners resulted in a reaction with reduced yield but high stereoselectivity.)

We developed a systematic nomenclature scheme so that we could extensively explore the remaining degrees of freedom. The conformations of the donor and acceptor were taken from the lowest six conformations found for the glucose 3,5bis(trifluoromethyl)sulfonate and labeled A-F. The orientation of the acceptor relative to the donor was designated as "up" (U) or "down" (D). The orientation of the aryl group of the arylsulfonate was designated as "left" (L) or "right" (R). This led to a four-character system for labeling candidate transition structures. For example, AAUL indicates that both the donor and acceptor were in the lowest-energy ground state conformation, with the acceptor in the "up" orientation and the leaving group in the "left" orientation. (A few configurations from exploratory work were designated as "original" using the abbreviations ORG1, ORG2, etc.) In some cases, the conformation drifted away from the original labeling during the transition state search. In all cases, the transition state label reflects the original label only.

After a comprehensive search, a total of 106 distinct transition states were found, spanning a range of $34 \mathrm{kcal} / \mathrm{mol}$ in electronic energy:

\begin{tabular}{l|c|c|c|c|c|r|}
\hline conformer & type & energy & forming & breaking & angle & imaginary \\
\hline FAUR & $\mathrm{a}$ & 0.0000 & 2.387 & 1.928 & 160.372 & 356 \\
CDUR & $\mathrm{a}$ & 1.7875 & 2.373 & 1.940 & 108.144 & 378
\end{tabular}




\begin{tabular}{|c|c|c|c|c|c|}
\hline CDDR & $a$ & 2.3228 & 2.426 & 1.948 & 162.949 \\
\hline ADDR & $\mathrm{a}$ & 2.3811 & 2.398 & 1.963 & 161.803 \\
\hline BCDR & $b$ & 2.4169 & 2.487 & 2.162 & 138.258 \\
\hline CADR & $\mathrm{a}$ & 2.8816 & 2.462 & 2.049 & 157.238 \\
\hline BCUR & $b$ & 3.2180 & 2.562 & 2.137 & 134.684 \\
\hline EADR & $b$ & 3.2608 & 2.500 & 2.182 & 134.646 \\
\hline CADR & $b$ & 3.3074 & 2.573 & 2.118 & 135.133 \\
\hline BCDL & $b$ & 3.5756 & 2.566 & 2.121 & 137.184 \\
\hline CCUL & $b$ & 3.6488 & 2.572 & 2.136 & 138.398 \\
\hline CCDL & $b$ & 3.6964 & 2.552 & 2.131 & 136.845 \\
\hline ECDR & $b$ & 4.6517 & 2.461 & 2.309 & 130.274 \\
\hline AAUL & $a$ & 4.7652 & 2.376 & 1.975 & 163.002 \\
\hline AADL & $\mathrm{a}$ & 4.7915 & 2.486 & 2.008 & 165.005 \\
\hline AADL & $b$ & 5.1097 & 2.486 & 2.341 & 122.858 \\
\hline FAUR & $b$ & 5.2527 & 2.429 & 2.355 & 132.056 \\
\hline ECUL & $b$ & 5.2927 & 2.538 & 2.120 & 135.039 \\
\hline CCUL & $\mathrm{a}$ & 5.3567 & 2.388 & 1.945 & 163.255 \\
\hline EDDR & $\mathrm{a}$ & 5.4600 & 2.403 & 1.922 & 164.772 \\
\hline CCDL & $a$ & 5.5779 & 2.459 & 2.034 & 163.988 \\
\hline DADL & $b$ & 5.5867 & 2.469 & 2.179 & 132.186 \\
\hline ACDR & $b$ & 5.9670 & 2.593 & 2.291 & 119.900 \\
\hline FCDL & $b$ & 6.0082 & 2.584 & 2.124 & 138.872 \\
\hline EADL & $b$ & 6.2948 & 2.513 & 2.243 & 122.770 \\
\hline DCDR & $b$ & 6.6099 & 2.513 & 2.377 & 116.013 \\
\hline BDDL & $a$ & 6.8750 & 2.398 & 1.944 & 162.230 \\
\hline DCUR & $b$ & 6.9934 & 2.646 & 2.018 & 132.206 \\
\hline ACDL & $a$ & 7.0170 & 2.468 & 1.990 & 164.277 \\
\hline DCDL & $b$ & 7.0430 & 2.546 & 2.183 & 129.313 \\
\hline FADL & $b$ & 7.2585 & 2.471 & 2.296 & 135.930 \\
\hline CADL & $a$ & 7.4560 & 2.453 & 1.986 & 164.854 \\
\hline EAUL & $a$ & 7.7936 & 2.360 & 1.948 & 161.075 \\
\hline CCDR & $b$ & 8.4397 & 2.589 & 2.152 & 138.821 \\
\hline BDUL & $\mathrm{a}$ & 8.4498 & 2.468 & 1.927 & 147.610 \\
\hline CADL & $b$ & 8.5692 & 2.532 & 2.218 & 125.902 \\
\hline FDUL & $b$ & 8.9756 & 2.557 & 2.251 & 135.189 \\
\hline BAUL & $\mathrm{a}$ & 9.3937 & 2.572 & 1.972 & 154.283 \\
\hline EADL & $a$ & 9.4944 & 2.473 & 1.951 & 163.967 \\
\hline AADR & $b$ & 9.6888 & 2.428 & 2.309 & 128.486 \\
\hline FDDR & $a$ & 9.8211 & 2.491 & 1.987 & 152.142 \\
\hline FCDR & $b$ & 10.3586 & 2.549 & 2.181 & 139.845 \\
\hline DDDL & $b$ & 10.3754 & 2.553 & 2.045 & 135.034 \\
\hline DDUR & $b$ & 10.4764 & 2.509 & 2.230 & 127.886 \\
\hline ADUL & $b$ & 10.6903 & 2.620 & 2.145 & 132.481 \\
\hline EAUR & $b$ & 10.8866 & 2.532 & 2.193 & 74.747 \\
\hline
\end{tabular}




\begin{tabular}{|c|c|c|c|c|c|}
\hline CAUR & $b$ & 11.0411 & 2.603 & 2.191 & 129.432 \\
\hline AAUR & $b$ & 11.1019 & 2.463 & 2.167 & 133.207 \\
\hline BCUL & $\mathrm{a}$ & 11.2037 & 2.566 & 1.930 & 151.347 \\
\hline AAUL & $\mathrm{a}$ & 11.3519 & 2.353 & 1.960 & 146.406 \\
\hline DDDR & $\mathrm{a}$ & 11.5284 & 2.413 & 1.981 & 160.300 \\
\hline BDUL & $b$ & 11.9100 & 2.611 & 2.178 & 129.549 \\
\hline ADDL & $b$ & 11.9492 & 2.587 & 2.272 & 124.322 \\
\hline DCUL & $b$ & 12.0487 & 2.611 & 2.139 & 130.964 \\
\hline EDDR & $b$ & 12.0557 & 2.674 & 2.223 & 124.882 \\
\hline FCUR & $b$ & 12.3964 & 2.437 & 2.213 & 131.863 \\
\hline BDDL & $\mathrm{a}$ & 12.6640 & 2.398 & 1.978 & 147.583 \\
\hline ECDL & $b$ & 12.9602 & 2.621 & 2.064 & 135.562 \\
\hline EDDL & $\mathrm{a}$ & 13.1272 & 2.530 & 1.911 & 150.383 \\
\hline CDUR & $b$ & 13.2539 & 2.468 & 2.197 & 136.650 \\
\hline ADUL & $\mathrm{a}$ & 13.2642 & 2.543 & 1.928 & 156.631 \\
\hline DADR & $b$ & 13.6975 & 2.574 & 2.276 & 128.596 \\
\hline ADUR & $\mathrm{a}$ & 13.8669 & 2.490 & 1.960 & 156.777 \\
\hline FAUL & $b$ & 14.4052 & 2.619 & 2.230 & 125.276 \\
\hline CADL & c & 14.5679 & 2.702 & 1.908 & 114.531 \\
\hline FADL & $\mathrm{a}$ & 14.9101 & 2.493 & 2.029 & 163.522 \\
\hline EDDL & $b$ & 14.9368 & 2.482 & 2.208 & 129.700 \\
\hline DCUR & $\mathrm{a}$ & 15.1039 & 2.557 & 2.001 & 148.644 \\
\hline BDDL & $b$ & 15.1777 & 2.470 & 2.357 & 127.840 \\
\hline DADL & $a$ & 15.2131 & 2.822 & 1.911 & 138.161 \\
\hline DAUR & $b$ & 15.2751 & 2.535 & 2.174 & 135.896 \\
\hline DCDL & $a$ & 16.0037 & 2.509 & 2.031 & 163.652 \\
\hline ECDL & $a$ & 16.0795 & 2.499 & 1.999 & 162.591 \\
\hline ORG2 & $\mathrm{a}$ & 16.1409 & 2.626 & 2.010 & 153.694 \\
\hline ADDR & $b$ & 16.4420 & 2.430 & 1.975 & 149.100 \\
\hline CCDR & $\mathrm{C}$ & 16.4478 & 2.695 & 1.817 & 134.083 \\
\hline BCUR & $c$ & 16.9232 & 2.751 & 1.781 & 149.145 \\
\hline BCUL & c & 17.6896 & 2.623 & 1.825 & 151.025 \\
\hline DCDL & $\mathrm{C}$ & 17.7963 & 2.604 & 1.765 & 164.215 \\
\hline ECUL & $c$ & 17.8996 & 2.479 & 2.761 & 92.161 \\
\hline DDUL & $a$ & 17.9494 & 2.627 & 1.868 & 159.366 \\
\hline DDDR & $b$ & 18.2475 & 2.523 & 2.283 & 125.952 \\
\hline FCDR & $c$ & 18.7734 & 2.613 & 1.844 & 147.192 \\
\hline EDDL & $b$ & 19.3966 & 2.426 & 2.307 & 133.981 \\
\hline DDUR & $a$ & 20.6249 & 2.631 & 1.895 & 148.945 \\
\hline BAUR & $\mathrm{c}$ & 21.4003 & 2.687 & 1.831 & 140.620 \\
\hline FCUL & $\mathrm{a}$ & 22.2016 & 2.643 & 1.919 & 145.955 \\
\hline DDUL & $b$ & 22.3042 & 2.637 & 1.845 & 139.746 \\
\hline CAUL & $\mathrm{C}$ & 22.3472 & 2.741 & 1.737 & 131.388 \\
\hline FCUL & c & 22.6774 & 2.466 & 1.769 & 157.986 \\
\hline
\end{tabular}




$\begin{array}{lllllll}\text { BCDR } & \text { c } & 22.6842 & 2.665 & 1.786 & 172.981 & 329 \\ \text { FADL } & \text { C } & 22.7471 & 2.601 & 1.760 & 150.465 & 311 \\ \text { BDUR } & \text { C } & 22.9521 & 2.596 & 1.961 & 142.747 & 142 \\ \text { DADL } & \text { C } & 23.2194 & 2.621 & 1.829 & 126.545 & 263 \\ \text { CDDL } & \text { C } & 23.4025 & 2.693 & 1.709 & 167.232 & 217 \\ \text { DAUR } & \text { C } & 23.6939 & 2.657 & 1.860 & 132.288 & 287 \\ \text { EDUL } & \text { C } & 24.4791 & 2.512 & 1.848 & 146.326 & 382 \\ \text { CCUL } & \text { C } & 25.0791 & 2.662 & 1.791 & 150.799 & 296 \\ \text { CCDL } & \text { C } & 25.8784 & 2.693 & 1.786 & 151.963 & 284 \\ \text { BCDL } & \text { C } & 25.9315 & 2.752 & 1.746 & 155.896 & 272 \\ \text { DCUL } & \text { C } & 28.5948 & 2.704 & 1.810 & 119.139 & 231 \\ \text { AADL } & \text { C } & 31.0292 & 2.657 & 1.932 & 126.166 & 122 \\ \text { CDDR } & \text { C } & 31.7619 & 2.720 & 1.750 & 136.283 & 206 \\ \text { AAUR } & \text { C } & 32.4446 & 2.681 & 1.863 & 158.016 & 283 \\ \text { DDDR } & \text { C } & 33.8933 & 2.587 & 1.707 & 162.901 & 316 \\ \text { AAUL } & \text { C } & 33.8940 & 2.668 & 1.828 & 169.793 & 369\end{array}$

Legend:

Conformer $=$ donor/acceptor conformation

Type $=$ solvation sphere geometry $(\mathrm{a}=$ sodium bound to alkoxide, $\mathrm{b}=$ bridging sodium, $\mathrm{c}=$ sodium bound to sulfonate)

Energy $=$ electronic energy in $\mathrm{kcal} / \mathrm{mol}$

Forming and breaking $=$ bond distances in $\AA$

Angle $=$ nucleophile-carbon-leaving-group angle, and imaginary refers to the curvature of the reaction coordinate in $\mathrm{cm}^{-1}$. The highlighted structure (BCDR, type b) near the top was the lowest in energy and is described in the main text.

The calculated KIEs were:

\begin{tabular}{l|l|c|c|c|c|c|c|c|}
\hline conformer & type & C1 & C2 & C3 & C4 & C5 & C6 & HD \\
\hline FAUR & $\mathrm{a}$ & 1.0821 & 1.0039 & 1.0007 & 1.0013 & 1.0008 & 1.0004 & 1.1882 \\
CDUR & $\mathrm{a}$ & 1.0836 & 1.0041 & 1.0003 & 1.0001 & 0.9988 & 0.9982 & 1.1064 \\
CDDR & $\mathrm{a}$ & 1.0756 & 1.0042 & 1.0011 & 1.0019 & 0.9995 & 0.9991 & 1.1955 \\
ADDR & $\mathrm{a}$ & 1.0759 & 1.0046 & 1.0014 & 1.0003 & 0.9984 & 0.9984 & 1.2136 \\
BCDR & $\mathrm{b}$ & 1.0362 & 1.0072 & 1.0023 & 1.0018 & 1.0056 & 0.9981 & 1.2991 \\
CADR & $\mathrm{a}$ & 1.0651 & 1.0072 & 1.0007 & 1.0012 & 1.0014 & 0.9988 & 1.2761 \\
BCUR & $\mathrm{b}$ & 1.0297 & 1.0060 & 1.0014 & 1.0024 & 1.0058 & 0.9987 & 1.3928 \\
EADR & $\mathrm{b}$ & 1.0306 & 1.0075 & 1.0020 & 1.0039 & 1.0099 & 1.0008 & 1.4268 \\
CADR & $\mathrm{b}$ & 1.0316 & 1.0058 & 1.0013 & 1.0022 & 1.0059 & 0.9985 & 1.3998 \\
BCDL & $\mathrm{b}$ & 1.0318 & 1.0057 & 1.0008 & 1.0022 & 1.0062 & 0.9985 & 1.3637 \\
CCUL & $\mathrm{b}$ & 1.0333 & 1.0062 & 1.0013 & 1.0018 & 1.0060 & 0.9985 & 1.3588 \\
CCDL & $\mathrm{b}$ & 1.0338 & 1.0049 & 1.0008 & 1.0021 & 1.0061 & 0.9985 & 1.3214 \\
ECDR & $\mathrm{b}$ & 1.0288 & 1.0122 & 1.0026 & 1.0025 & 1.0051 & 0.9994 & 1.3205 \\
AAUL & $\mathrm{a}$ & 1.0790 & 1.0041 & 1.0000 & 1.0011 & 1.0002 & 0.9989 & 1.1840
\end{tabular}




\begin{tabular}{|c|c|c|c|c|c|c|c|c|}
\hline AADL & $a$ & 1.0634 & 1.0046 & 1.0002 & 1.0013 & 1.0007 & 0.9990 & 1.1943 \\
\hline AADL & $b$ & 1.0187 & 1.0080 & 1.0019 & 1.0024 & 1.0062 & 0.9986 & 1.4929 \\
\hline FAUR & $b$ & 1.0285 & 1.0067 & 1.0007 & 1.0026 & 1.0080 & 0.9999 & 1.4067 \\
\hline ECUL & $b$ & 1.0315 & 1.0059 & 1.0020 & 1.0040 & 1.0093 & 1.0013 & 1.4113 \\
\hline CCUL & $a$ & 1.0811 & 1.0029 & 0.9996 & 1.0009 & 1.0004 & 0.9989 & 1.2133 \\
\hline EDDR & $\mathrm{a}$ & 1.0771 & 1.0032 & 1.0014 & 1.0023 & 1.0042 & 1.0022 & 1.2128 \\
\hline CCDL & $a$ & 1.0648 & 1.0058 & 1.0002 & 1.0006 & 1.0014 & 0.9990 & 1.2106 \\
\hline DADL & $b$ & 1.0328 & 1.0064 & 1.0014 & 1.0049 & 1.0116 & 1.0012 & 1.4621 \\
\hline ACDR & $b$ & 1.0170 & 1.0103 & 1.0063 & 1.0078 & 1.0072 & 0.9996 & 1.6830 \\
\hline FCDL & $b$ & 1.0350 & 1.0055 & 1.0008 & 1.0029 & 1.0066 & 0.9995 & 1.3349 \\
\hline EADL & $b$ & 1.0205 & 1.0072 & 1.0027 & 1.0044 & 1.0115 & 1.0020 & 1.5152 \\
\hline DCDR & $b$ & 1.0164 & 1.0125 & 1.0094 & 1.0082 & 1.0091 & 1.0042 & 1.7543 \\
\hline BDDL & $a$ & 1.0790 & 1.0032 & 0.9996 & 1.0008 & 0.9999 & 0.9987 & 1.2073 \\
\hline DCUR & $b$ & 1.0301 & 1.0040 & 1.0014 & 1.0031 & 1.0122 & 1.0030 & 1.3763 \\
\hline ACDL & $a$ & 1.0691 & 1.0060 & 0.9998 & 1.0006 & 1.0007 & 0.9990 & 1.2038 \\
\hline DCDL & $b$ & 1.0265 & 1.0059 & 1.0008 & 1.0045 & 1.0136 & 1.0030 & 1.4827 \\
\hline FADL & $b$ & 1.0303 & 1.0075 & 1.0010 & 1.0023 & 1.0081 & 1.0005 & 1.4510 \\
\hline CADL & $a$ & 1.0701 & 1.0057 & 0.9998 & 1.0007 & 1.0002 & 0.9988 & 1.1977 \\
\hline EAUL & $\mathrm{a}$ & 1.0792 & 1.0043 & 1.0011 & 1.0024 & 1.0021 & 1.0019 & 1.1480 \\
\hline CCDR & $b$ & 1.0308 & 1.0060 & 1.0013 & 1.0019 & 1.0066 & 0.9985 & 1.2926 \\
\hline BDUL & $\mathrm{a}$ & 1.0744 & 1.0041 & 1.0002 & 1.0005 & 1.0012 & 0.9988 & 1.2784 \\
\hline CADL & $b$ & 1.0237 & 1.0104 & 1.0069 & 1.0084 & 1.0059 & 0.9998 & 1.3707 \\
\hline FDUL & $b$ & 1.0269 & 1.0069 & 1.0018 & 1.0032 & 1.0069 & 1.0001 & 1.3685 \\
\hline BAUL & $\mathrm{a}$ & 1.0593 & 1.0041 & 0.9996 & 1.0004 & 1.0022 & 0.9993 & 1.2867 \\
\hline EADL & $a$ & 1.0711 & 1.0052 & 1.0008 & 1.0007 & 1.0039 & 1.0034 & 1.1722 \\
\hline AADR & $b$ & 1.0300 & 1.0120 & 1.0007 & 1.0004 & 1.0074 & 0.9988 & 1.3577 \\
\hline FDDR & $a$ & 1.0643 & 1.0041 & 1.0002 & 1.0010 & 1.0012 & 0.9982 & 1.2539 \\
\hline FCDR & $b$ & 1.0324 & 1.0069 & 1.0020 & 1.0029 & 1.0058 & 0.9997 & 1.2806 \\
\hline DDDL & $b$ & 1.0380 & 1.0050 & 1.0007 & 1.0041 & 1.0113 & 1.0020 & 1.4041 \\
\hline DDUR & $b$ & 1.0267 & 1.0054 & 1.0014 & 1.0054 & 1.0124 & 1.0013 & 1.5007 \\
\hline ADUL & $b$ & 1.0274 & 1.0073 & 1.0027 & 1.0013 & 1.0095 & 1.0007 & 1.4267 \\
\hline EAUR & $b$ & 1.0269 & 1.0093 & 1.0029 & 1.0041 & 1.0097 & 1.0014 & 1.3099 \\
\hline CAUR & $b$ & 1.0214 & 1.0054 & 1.0015 & 0.9997 & 1.0051 & 0.9988 & 1.3850 \\
\hline AAUR & $b$ & 1.0420 & 1.0112 & 1.0013 & 0.9998 & 1.0033 & 0.9968 & 1.3019 \\
\hline BCUL & $a$ & 1.0683 & 1.0048 & 0.9998 & 1.0018 & 1.0000 & 0.9984 & 1.2707 \\
\hline AAUL & $a$ & 1.0849 & 1.0038 & 1.0007 & 1.0002 & 0.9995 & 0.9989 & 1.2000 \\
\hline DDDR & $a$ & 1.0717 & 1.0036 & 1.0000 & 1.0025 & 1.0064 & 0.9998 & 1.2492 \\
\hline BDUL & $b$ & 1.0227 & 1.0060 & 1.0013 & 1.0020 & 1.0057 & 0.9994 & 1.5015 \\
\hline ADDL & $b$ & 1.0174 & 1.0109 & 1.0032 & 1.0040 & 1.0080 & 0.9993 & 1.7364 \\
\hline DCUL & $b$ & 1.0271 & 1.0060 & 1.0010 & 1.0029 & 1.0121 & 1.0023 & 1.4148 \\
\hline EDDR & $b$ & 1.0193 & 1.0059 & 1.0013 & 1.0031 & 1.0107 & 1.0024 & 1.4533 \\
\hline FCUR & $b$ & 1.0354 & 1.0098 & 1.0015 & 1.0033 & 1.0114 & 1.0021 & 1.2570 \\
\hline BDDL & $a$ & 1.0708 & 1.0050 & 1.0007 & 1.0006 & 1.0021 & 0.9975 & 1.1000 \\
\hline ECDL & $\mathrm{b}$ & 1.0315 & 1.0053 & 1.0016 & 1.0025 & 1.0070 & 1.0005 & 1.3039 \\
\hline
\end{tabular}




\begin{tabular}{|c|c|c|c|c|c|c|c|c|}
\hline EDDL & a & 1.0681 & 1.0048 & 1.0001 & 1.0036 & 1.0040 & 1.0016 & 1.2202 \\
\hline CDUR & b & 1.0384 & 1.0107 & 1.0007 & 0.9992 & 1.0028 & 0.9983 & 1.3813 \\
\hline ADUL & a & 1.0608 & 1.0036 & 0.9993 & 1.0006 & 1.0049 & 1.0004 & 1.1763 \\
\hline DADR & $b$ & 1.0244 & 1.0112 & 1.0014 & 1.0036 & 1.0117 & 1.0023 & 1.4469 \\
\hline ADUR & a & 1.0597 & 1.0032 & 0.9996 & 1.0007 & 1.0047 & 1.0005 & 1.1726 \\
\hline FAUL & b & 1.0228 & 1.0115 & 1.0069 & 1.0071 & 1.0063 & 1.0024 & 1.4756 \\
\hline CADL & c & 1.0396 & 1.0042 & 1.0035 & 1.0070 & 1.0090 & 1.0021 & 1.4866 \\
\hline FADL & a & 1.0599 & 1.0047 & 1.0005 & 1.0016 & 1.0005 & 0.9972 & 1.1952 \\
\hline EDDL & b & 1.0344 & 1.0106 & 1.0023 & 1.0031 & 1.0074 & 1.0010 & 1.3685 \\
\hline DCUR & a & 1.0531 & 1.0041 & 1.0008 & 1.0032 & 1.0082 & 1.0005 & 1.2722 \\
\hline BDDL & b & 1.0239 & 1.0076 & 1.0005 & 1.0011 & 1.0079 & 0.9986 & 1.4516 \\
\hline DADL & a & 1.0415 & 1.0047 & 0.9999 & 1.0034 & 1.0060 & 1.0001 & 1.0918 \\
\hline DAUR & b & 1.0353 & 1.0082 & 1.0019 & 1.0027 & 1.0099 & 1.0011 & 1.3126 \\
\hline DCDL & a & 1.0579 & 1.0036 & 1.0002 & 1.0029 & 1.0061 & 1.0000 & 1.1922 \\
\hline ECDL & $a$ & 1.0586 & 1.0052 & 1.0010 & 1.0014 & 1.0026 & 0.9995 & 1.1962 \\
\hline ORG2 & a & 1.0575 & 1.0114 & 0.9999 & 1.0006 & 1.0029 & 1.0024 & 1.1074 \\
\hline ADDR & $b$ & 1.0685 & 1.0051 & 1.0003 & 1.0010 & 1.0010 & 0.9978 & 1.2186 \\
\hline CCDR & c & 1.0597 & 1.0000 & 0.9980 & 1.0026 & 1.0024 & 0.9989 & 1.2953 \\
\hline BCUR & c & 1.0655 & 1.0034 & 1.0000 & 0.9996 & 0.9995 & 0.9978 & 1.1666 \\
\hline BCUL & c & 1.0737 & 1.0047 & 0.9991 & 0.9991 & 0.9989 & 0.9972 & 1.2126 \\
\hline DCDL & c & 1.0756 & 1.0006 & 1.0036 & 1.0080 & 1.0065 & 1.0044 & 1.2120 \\
\hline ECUL & $c$ & 1.0131 & 1.0119 & 1.0018 & 1.0040 & 1.0106 & 1.0020 & 1.9210 \\
\hline DDUL & $a$ & 1.0650 & 1.0020 & 1.0024 & 1.0071 & 1.0098 & 1.0053 & 1.1356 \\
\hline DDDR & $b$ & 1.0209 & 1.0066 & 1.0009 & 1.0044 & 1.0142 & 1.0040 & 1.4893 \\
\hline FCDR & $c$ & 1.0691 & 1.0035 & 0.9992 & 1.0011 & 1.0005 & 0.9994 & 1.2657 \\
\hline EDDL & $b$ & 1.0272 & 1.0075 & 1.0015 & 1.0032 & 1.0083 & 1.0016 & 1.4589 \\
\hline DDUR & $a$ & 1.0595 & 1.0032 & 0.9979 & 1.0024 & 1.0058 & 1.0007 & 1.1544 \\
\hline BAUR & $c$ & 1.0656 & 1.0010 & 0.9992 & 1.0002 & 1.0018 & 0.9981 & 1.2667 \\
\hline FCUL & $a$ & 1.0593 & 1.0058 & 1.0011 & 1.0028 & 0.9993 & 0.9995 & 1.2237 \\
\hline DDUL & $b$ & 1.0526 & 1.0014 & 1.0041 & 1.0066 & 1.0096 & 1.0038 & 1.1660 \\
\hline CAUL & $c$ & 1.0508 & 0.9978 & 0.9991 & 1.0040 & 0.9996 & 0.9984 & 1.3209 \\
\hline FCUL & 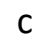 & 1.0934 & 1.0111 & 1.0005 & 0.9999 & 0.9985 & 1.0003 & 1.0906 \\
\hline BCDR & $c$ & 1.0759 & 1.0070 & 1.0012 & 0.9987 & 0.9989 & 0.9969 & 1.1149 \\
\hline FADL & $\mathrm{C}$ & 1.0623 & 1.0034 & 1.0071 & 1.0036 & 1.0004 & 1.0050 & 1.1853 \\
\hline BDUR & $c$ & 1.0387 & 1.0059 & 0.9999 & 1.0003 & 1.0023 & 0.9978 & 1.4100 \\
\hline DADL & $c$ & 1.0596 & 0.9999 & 0.9990 & 1.0044 & 1.0083 & 1.0009 & 1.3642 \\
\hline CDDL & $c$ & 1.0635 & 1.0025 & 1.0037 & 1.0088 & 1.0060 & 1.0048 & 1.1011 \\
\hline DAUR & $c$ & 1.0582 & 1.0032 & 1.0015 & 1.0026 & 1.0081 & 1.0012 & 1.4972 \\
\hline EDUL & $\mathrm{C}$ & 1.0766 & 1.0035 & 1.0011 & 1.0029 & 1.0034 & 0.9998 & 1.3198 \\
\hline CCUL & $c$ & 1.0670 & 1.0007 & 0.9994 & 1.0019 & 0.9997 & 0.9980 & 1.2670 \\
\hline CCDL & $c$ & 1.0669 & 1.0013 & 0.9996 & 1.0013 & 0.9997 & 0.9983 & 1.2418 \\
\hline BCDL & $\mathrm{C}$ & 1.0663 & 1.0008 & 0.9989 & 1.0003 & 0.9998 & 0.9980 & 1.1570 \\
\hline DCUL & $c$ & 1.0562 & 1.0022 & 1.0009 & 1.0028 & 1.0095 & 1.0010 & 1.4230 \\
\hline AADL & C & 1.0395 & 1.0051 & 1.0004 & 1.0006 & 1.0027 & 0.9989 & 1.9306 \\
\hline
\end{tabular}




$\begin{array}{lllllllll}\text { CDDR } & \mathrm{C} & 1.0566 & 0.9981 & 0.9999 & 1.0064 & 1.0011 & 0.9982 & 1.2364 \\ \text { AAUR } & \mathrm{C} & 1.0653 & 1.0068 & 1.0000 & 0.9997 & 1.0010 & 0.9968 & 1.2392 \\ \text { DDDR } & \mathrm{C} & 1.0749 & 1.0016 & 1.0042 & 1.0064 & 1.0036 & 1.0050 & 1.0938 \\ \text { AAUL } & \mathrm{C} & 1.0764 & 1.0075 & 1.0003 & 1.0018 & 1.0049 & 1.0033 & 1.0618\end{array}$

For each structure, KIEs were calculated at $213 \mathrm{~K}$ relative to the lowest energy conformation of permethyl-glucose bis-trifluoromethyl sulfonate (used previously as the reference for the $\mathrm{S}_{\mathrm{N}} 1$ analysis). All KIEs were calculated with unscaled vibrational frequencies and employed the Bell tunneling correction. ${ }^{[27]}$

The transition states were classified into three types by the coordination geometry of sodium: (a) bound to alkoxide (red); (b) bridging (green); and (c) bound to sulfonate (blue). These transition states spanned a range of geometries:

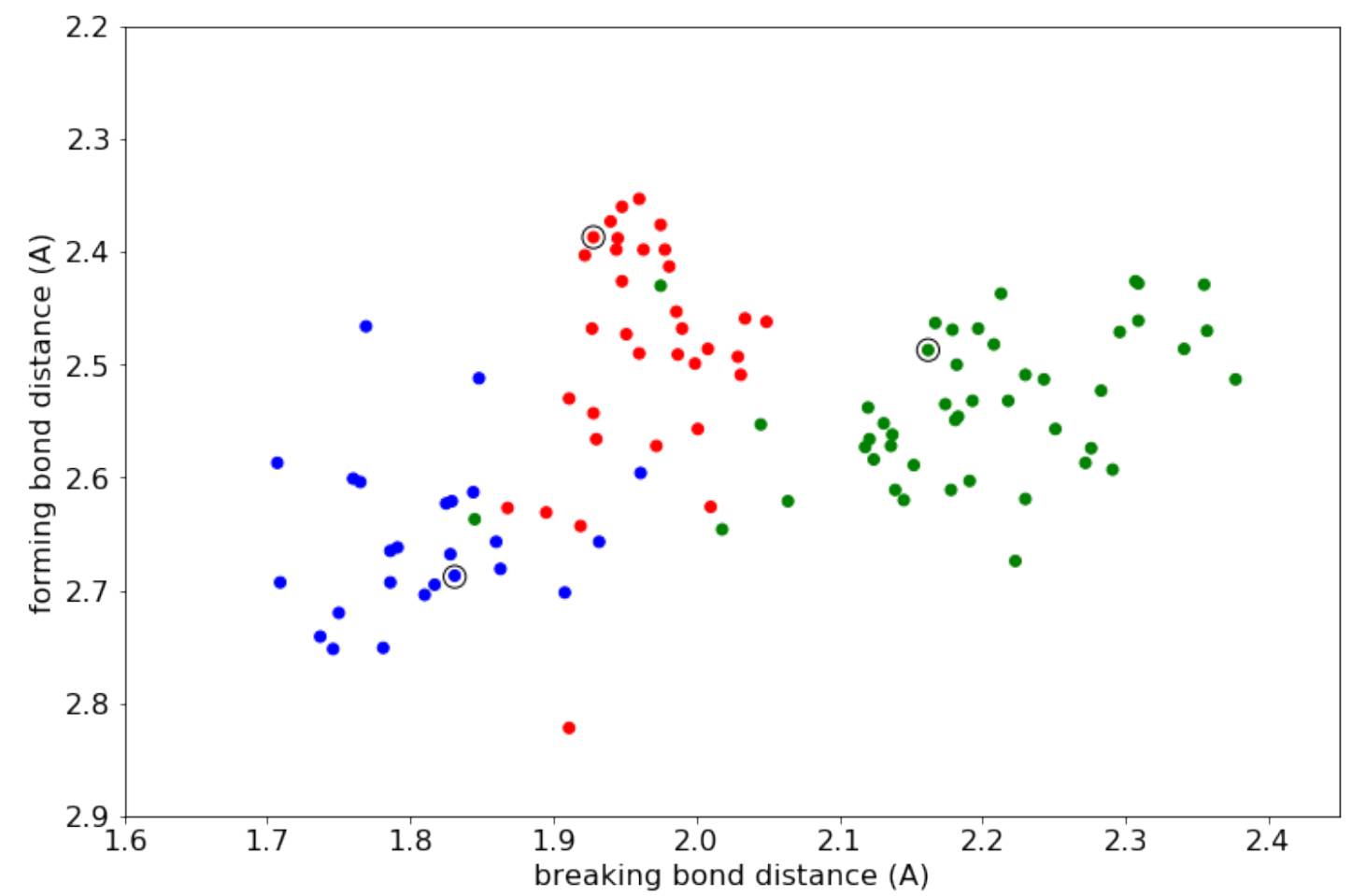

Figure S6. Transition structures for glycosylation. The highlighted points are the lowest-energy structures within each transition state type. The green transition states are consistent with experiment.

The KIE at C1 was particularly characteristic of each transition state type: 


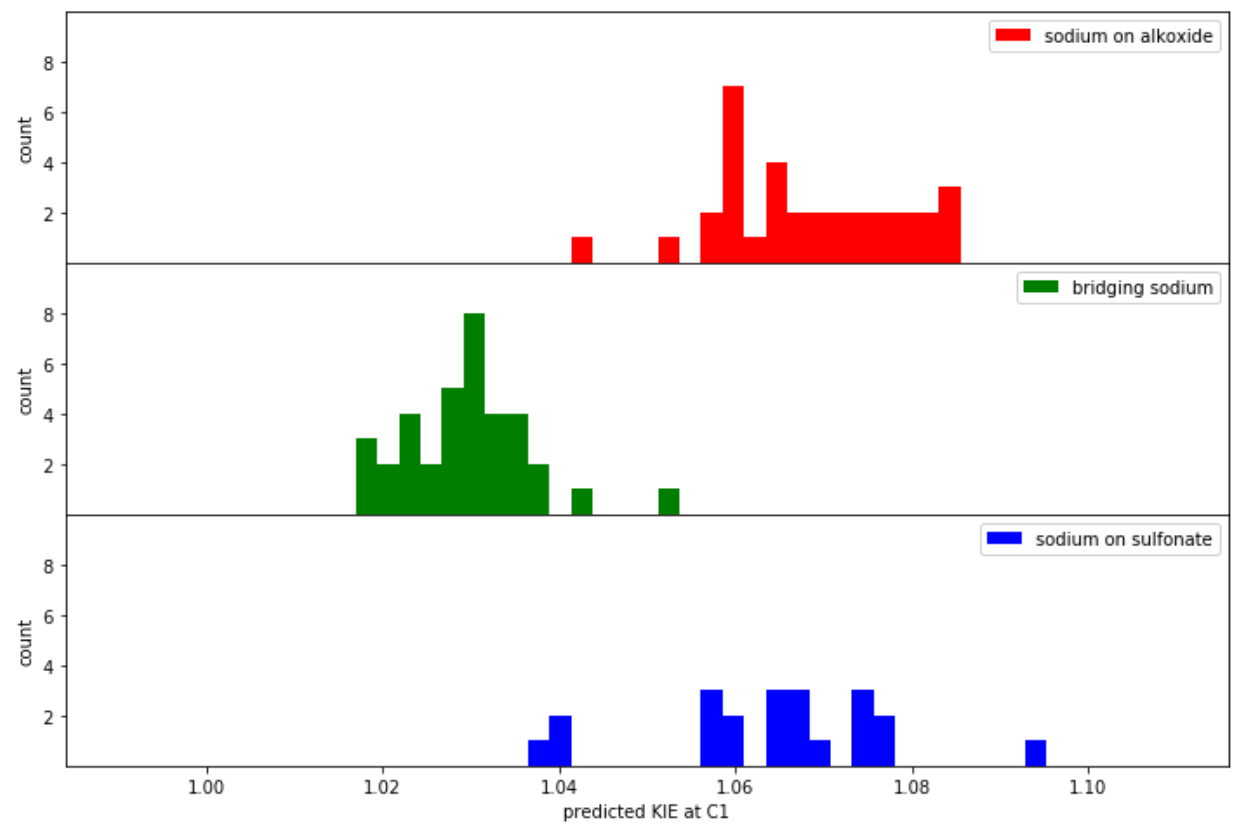

To examine the validity of the constrained transition state approach, the lowest-energy type a structure was constrained to the forming and breaking bond distances of the lowest energy type b structure (and vice versa). The results were:

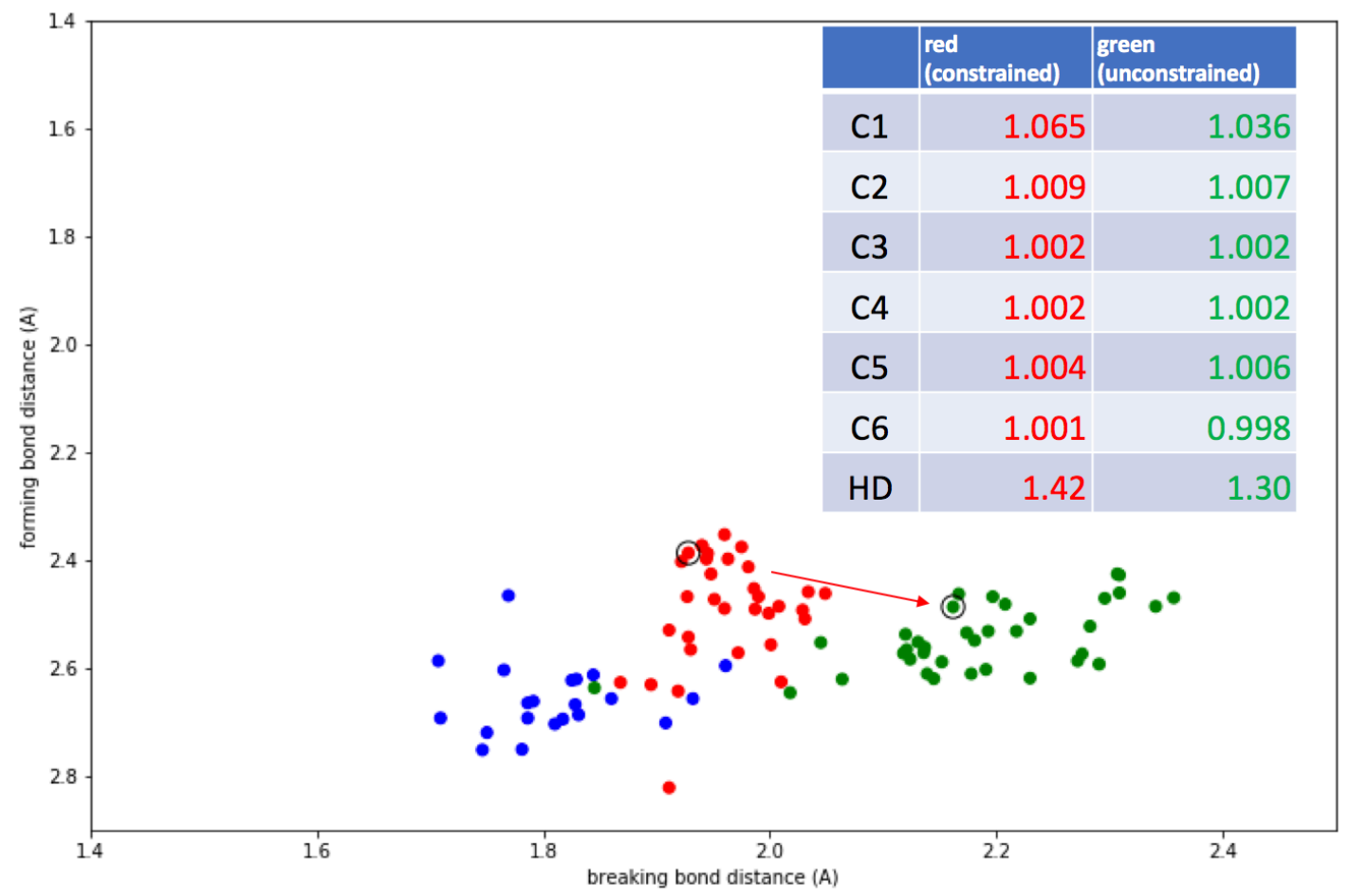




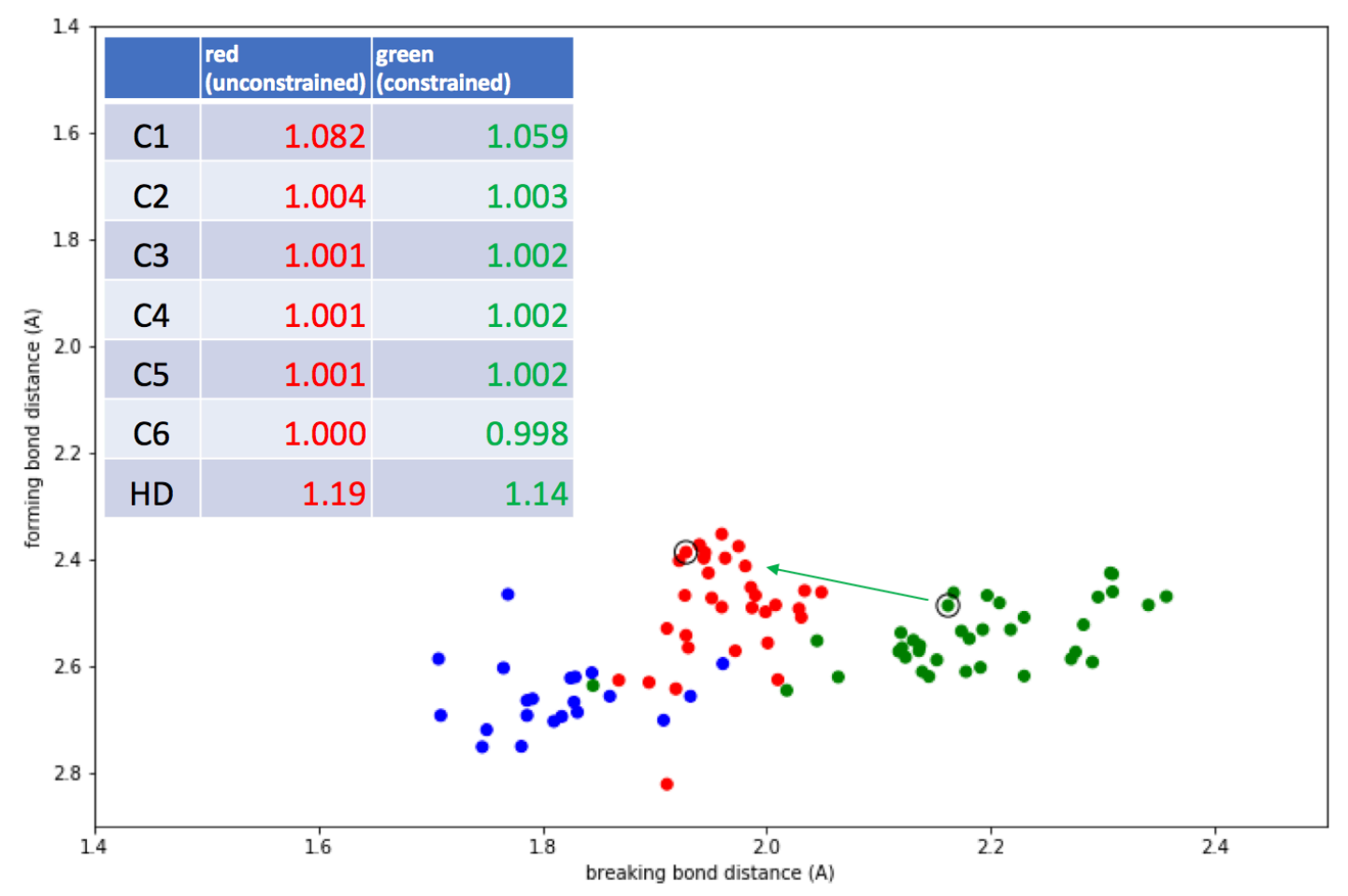

We also constructed a regression model for the type a structures:

predicted $\mathrm{KIE}$ at $\mathrm{C} 1=$

$-0.0452 \times$ forming bond distance

$-0.0321 \mathrm{x}$ breaking bond distance

$+0.0086 \mathrm{x}$ imaginary frequency / 100

$+1.2204$

The fit was good:

adj. $R^{2}=0.946$

RMS error $=0.002$

However, when this regression model was used for the type b structures, a substantial systematic error was observed: 


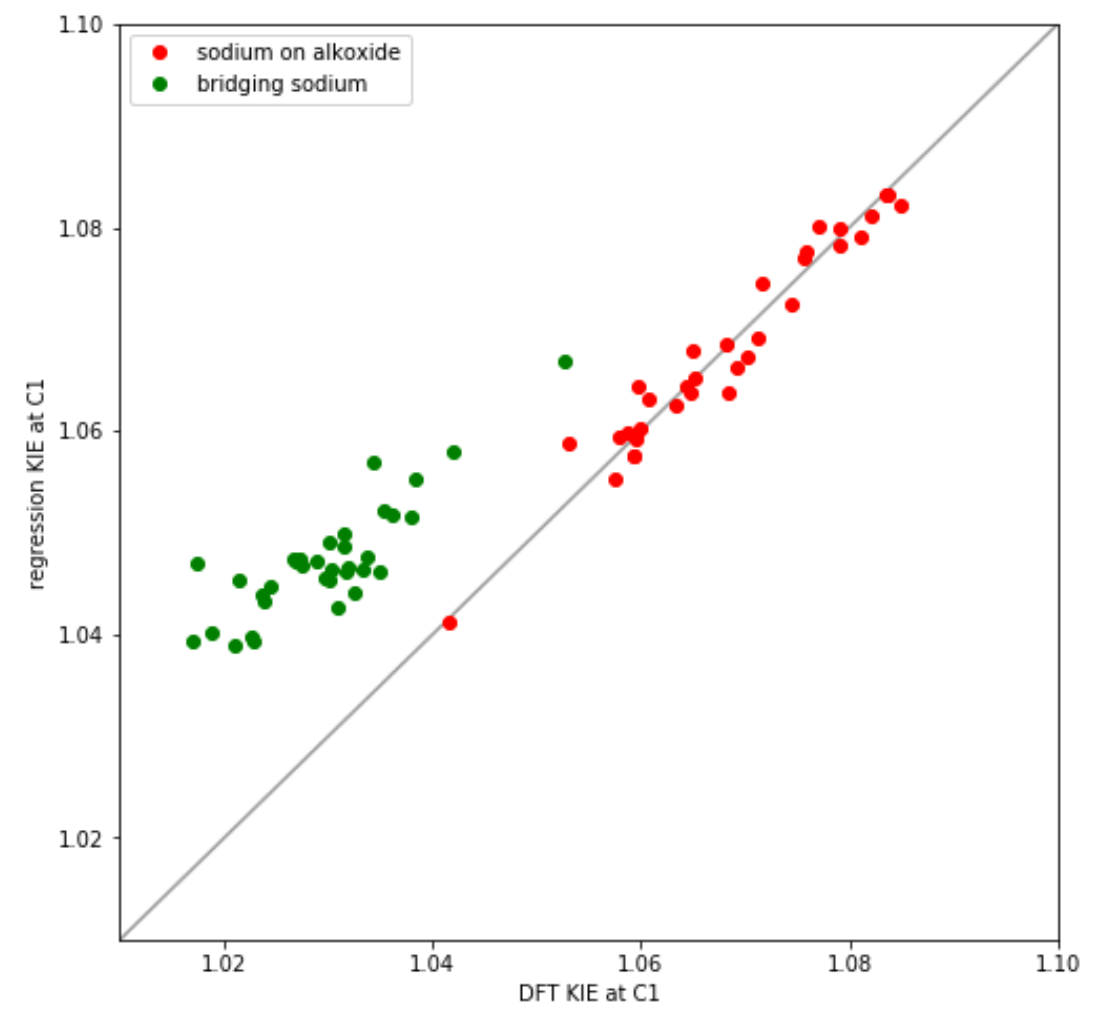

Thus, it is not always true that KIEs are largely dependent on geometric parameters and independent of mechanism (or DFT method). The constrained transition state approach should be used with caution.

\subsection{Choice of computational method for modeling $S_{N} 2$-like glycosylations}

The analysis above relied on B3LYP-D3(BJ)/6-31G*/PCM as a "standard" computational method that is expected to work reasonably well for glycosylation reactions. In this section, we consider what might have happened if we had chosen a different computational method. The lowest-energy type $b$ transition structure (BCDR) was re-optimized with 28 other functionals:

\begin{tabular}{|c|c|c|c|c|}
\hline theory & forming & breaking & angle & imaginary \\
\hline b1b95 & 2.441 & 2.181 & 140.191 & 169 \\
\hline b3lyp & 2.517 & 2.230 & 134.450 & 140 \\
\hline b3lyp_d3bj & 2.487 & 2.162 & 138.258 & 155 \\
\hline b3p86 & 2.448 & 2.154 & 138.458 & 202 \\
\hline b971 & 2.508 & 2.209 & 135.687 & 175 \\
\hline b972 & 2.508 & 2.285 & 130.981 & 122 \\
\hline b97d & 2.574 & 2.142 & 142.107 & 153 \\
\hline b97d3 & 2.576 & 2.187 & 136.883 & 108 \\
\hline b97d3_d3bj & 2.558 & 2.175 & 136.971 & 108 \\
\hline b98 & 2.508 & 2.226 & 134.834 & 161 \\
\hline bhandh & 2.290 & 2.053 & 145.758 & 307 \\
\hline
\end{tabular}




\begin{tabular}{|c|c|c|c|c|}
\hline bhandhlyp & 2.468 & 2.237 & 134.900 & 108 \\
\hline blyp_d3bj & 2.560 & 2.168 & 137.511 & 117 \\
\hline bp86_d3bj & 2.486 & 2.123 & 141.020 & 169 \\
\hline cam_b3lyp_d3bj & 2.424 & 2.155 & 139.961 & 202 \\
\hline Icwpbe_d3bj & 2.367 & 2.126 & 143.478 & 265 \\
\hline $\mathrm{m} 062 \mathrm{x}$ & 2.376 & 2.158 & 143.477 & 258 \\
\hline m062x_d3 & 2.375 & 2.154 & 142.944 & 270 \\
\hline m06_hf_d3 & 2.229 & 2.022 & 150.020 & 524 \\
\hline m06I_d3 & 2.549 & 2.113 & 138.465 & 101 \\
\hline m11 & 2.407 & 2.123 & 144.898 & 252 \\
\hline mpw1lyp & 2.507 & 2.220 & 135.122 & 140 \\
\hline mpw1pbe & 2.442 & 2.185 & 137.625 & 190 \\
\hline mpw1pw91 & 2.451 & 2.187 & 137.359 & 183 \\
\hline mpw3pbe & 2.458 & 2.184 & 137.504 & 186 \\
\hline n12sx & 2.434 & 2.130 & 140.091 & 243 \\
\hline pbe0 & 2.441 & 2.159 & 139.123 & 205 \\
\hline pbe0_d3bj & 2.413 & 2.128 & 141.689 & 220 \\
\hline tpsstpss_d3bj & 2.487 & 2.093 & 141.485 & 169 \\
\hline
\end{tabular}

The corresponding predicted KIEs were:

\begin{tabular}{|c|c|c|c|c|c|c|c|}
\hline$y$ & C1 & C2 & C3 & C4 & C5 & C6 & ID \\
\hline b: & 4428 & 0084 & 1.0027 & 0010 & .0045 & 9982 & 2420 \\
\hline b & 0296 & 1.0087 & 1.0023 & 1.0012 & 1.0065 & .9982 & 1.4172 \\
\hline b3ly & 1.0362 & 1.0072 & 1.0023 & 1.0018 & 1.0056 & 0.9981 & 1.2991 \\
\hline b3p86 & 0453 & 1.0084 & 1.0022 & 1.0009 & 1.0042 & 0.9980 & 1.3324 \\
\hline b971 & 1.0345 & 1.0087 & 1.0023 & 1.0013 & 1.0053 & 0.9980 & 1.5064 \\
\hline b972 & 1.0274 & 1.0098 & 1.0020 & 1.0012 & 1.0068 & 0.9983 & 1.5301 \\
\hline b97 & 1.0352 & 1.0049 & 1.0017 & 1.0023 & 1.0061 & 0.9968 & 1.1909 \\
\hline D & 0271 & 1.0067 & 1.0021 & 1.0021 & 1.0060 & 0.9976 & 1.3631 \\
\hline b97d & 9 & 1.0 & 1.0 & 1.0 & 55 & 80 & 015 \\
\hline & 0 & 1.0 & $1 . c$ & 13 & 59 & 80 & 062 \\
\hline bhandh & 1.0742 & 1.0052 & 1.0024 & 1.0021 & 1.0035 & 0.9983 & 1.1051 \\
\hline bhand & 1.0297 & 1.0095 & 1.0023 & 1.0011 & 1.0073 & 0.9987 & 1.3214 \\
\hline blyp_d3bj & 1.0268 & 1.0066 & 1.0025 & 1.0024 & 1.0054 & 0.9977 & 1.3708 \\
\hline bp86_d3bj & 1.0382 & 1.0061 & 1.0020 & 1.0020 & 1.0045 & 0.9978 & 1.3159 \\
\hline cam_b3lyp_d3bj & 1.0464 & 1.0073 & 1.0022 & 1.0015 & 1.0047 & 0.9981 & 1.2215 \\
\hline Icwpbe_d3bj & 1.0633 & 1.0069 & 1.0023 & 1.0010 & 1.0040 & 0.9983 & 1.2086 \\
\hline $\mathrm{m} 062 x$ & .0607 & 1.0068 & 1.0028 & 1.0013 & 1.0042 & 0.9983 & 1.1215 \\
\hline m062x_d3 & 1.0611 & 1.0067 & 1.0031 & 1.0016 & 1.0043 & 0.9983 & 1.1458 \\
\hline m06_hf_d3 & 1.1153 & 1.0031 & 1.0027 & 1.0011 & 1.0004 & 0.9977 & 1.0234 \\
\hline m061_d3 & 1.0322 & 1.0078 & 1.0041 & 1.0019 & 1.0058 & 0.9982 & 1.3699 \\
\hline-6 & 1.0560 & 1.0056 & 1.0033 & 1.0013 & 1.0037 & 0.9981 & 1.1151 \\
\hline
\end{tabular}




\begin{tabular}{|c|c|c|c|c|c|c|c|}
\hline $\mathrm{mp}$ & 1.0307 & 1.0085 & 1.0023 & 1.0014 & 1.0064 & 0.9982 & 1.3750 \\
\hline$-5+2>$ & 438 & 1.0091 & 1.0024 & 1.0008 & 1.0048 & 0.9980 & 3521 \\
\hline mpw1 & 424 & 1.0091 & 1.0024 & 1.0008 & 1.0050 & 0.9980 & 3537 \\
\hline $\mathrm{mpu}$ & 4 & 088 & 5 & 0 & 1.0049 & 0.9979 & 564 \\
\hline- & 1.0531 & 1.0074 & 1.0022 & 1.0014 & 1.0037 & 0.9983 & 1.3034 \\
\hline pbe0 & 1.0472 & 1.0086 & 1.0024 & 1.0010 & 1.0043 & 0.9981 & 1.3172 \\
\hline 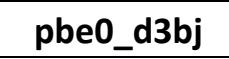 & 1.0519 & 1.0072 & 1.0024 & 1.0014 & 1.0043 & 0.9979 & 1.2553 \\
\hline id & 1.0391 & 1.0060 & 1.0023 & 1.0021 & 1.0043 & 0.9980 & 1.3080 \\
\hline
\end{tabular}

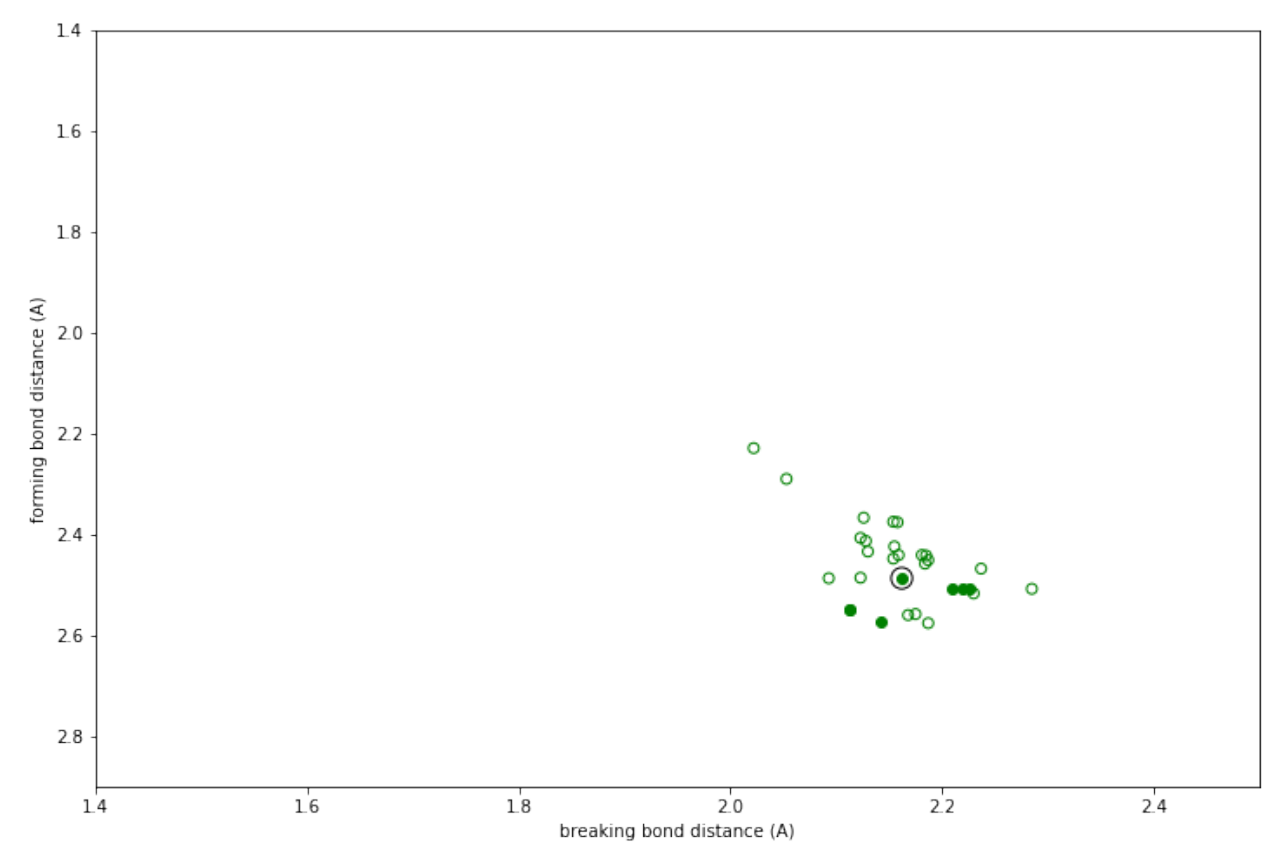

Figure S7. Dependence of transition structure on DFT. Each circle represents a transition state. Shaded circles give predicted KIEs at $\mathrm{C} 1$ that are within one standard deviation of the experimental mean. The black circle surrounds the B3LYP-D3(BJ) structure. The starting material would be in the lower right, while the product would be in the upper right. All structures used 6-31G* and PCM(THF).

Although the transition structures predicted by various DFTs are qualitatively similar, the predicted KIEs at $\mathrm{C} 1$ span a broad range from 1.027 to 1.115 with an average value of 1.044. Furthermore, the above plot suggests a positive correlation between the forming and breaking bond distances (note the inverted y-axis). This correlation can be interpreted as different DFTs varying in the degree to which they predict "tight" or "loose" transition states.

Furthermore, there is a strong correlation between the forming bond length and the predicted $\mathrm{KIE}$ at $\mathrm{C} 1$ : 


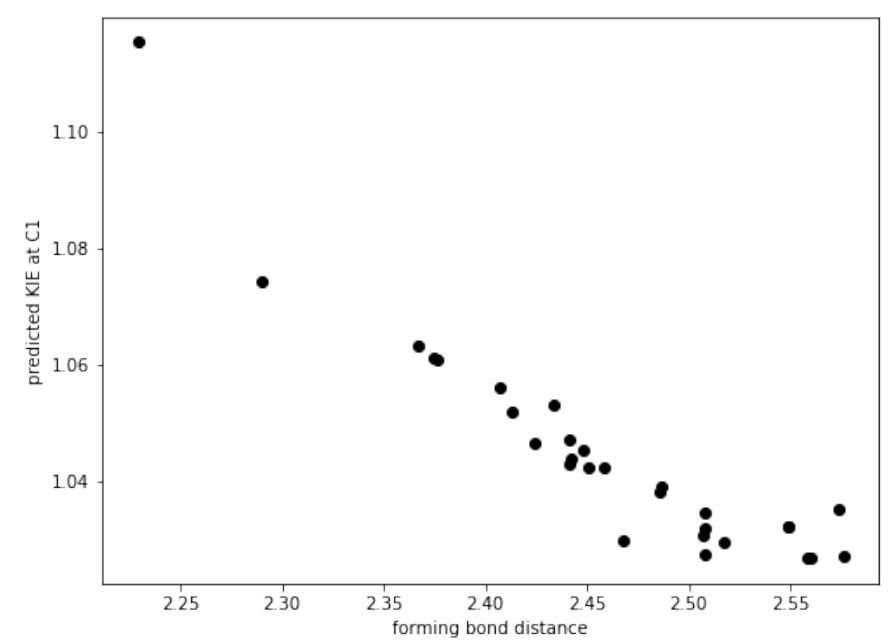

Figure S8. The predicted KIEs at C1 across 29

DFTs are highly correlated with the forming bond distance.

This result suggests that, although a variety of geometries can be obtained by varying the choice of DFT, only a few of those geometries will be consistent with experiment. Furthermore, Figure S7 also suggests that B3LYP-D3(BJ) predicts an "average" geometry with respect to the predictions of other functionals. To explore this idea in more detail, we performed a principal components analysis (PCA). A range of geometric parameters were taken as features: the forming bond distance, the breaking bond distance, the nucleophile-C1-leaving-group angle, the sodium alkoxide distance, the sodium-sulfonate oxygen bond distance, the C1-sodium-sulfonate oxygen bond angle, and the C6-O-C1-nucleophile dihedral angle. Each feature was normalized to a mean of 0 and a standard deviation of 1 . Then, a PCA analysis was performed (on all 8 dimensions). The explained variance for each parameter was (values in \%):

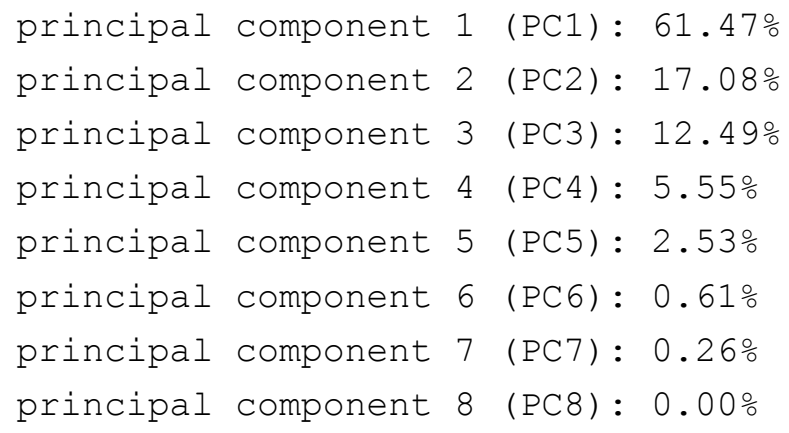

Thus, the first principal component (PC1) and second principal component (PC2) explained $79 \%$ of the variance. B3LYP-D3(BJ) is also near the centroid in PCA space: 


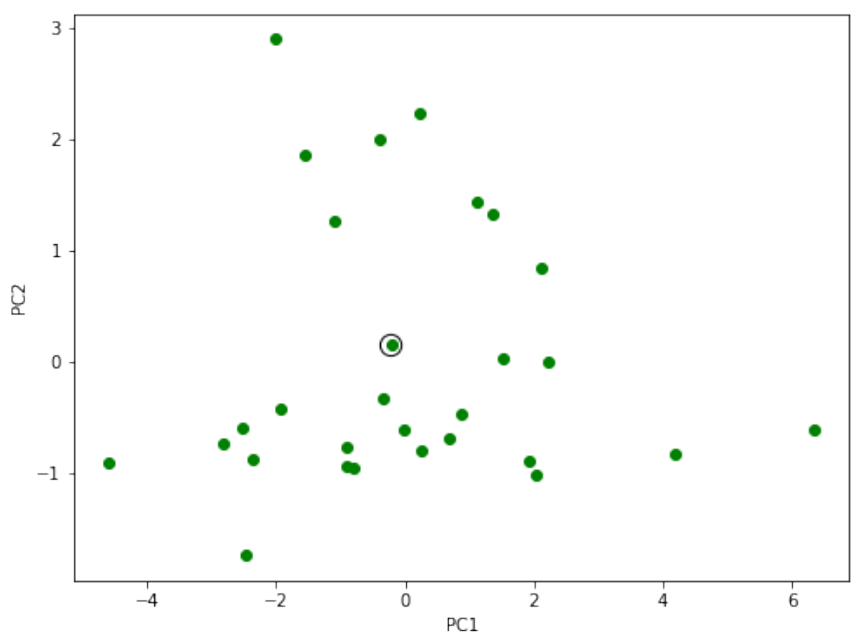

Figure S9. Principal components analysis of the transition structures predicted by various DFTs. The B3LYP-D3(BJ) geometry is near the centroid and can be considered a "typical" prediction.

The finding that B3LYP-D3(BJ) is a "typical" prediction indicates that the good agreement between theory and experiment cannot be ascribed to the fortuitous generation of an implausible geometry, due to an unexpected deficiency of B3LYPD3(BJ). While further benchmark studies, will be necessary to evaluate the accuracy of B3LYP-D3(BJ) as a method for predicting glycosylation KIEs, the results above provide reasonable ground to choose B3LYP-D3(BJ) as an interim method.

Having addressed the choice of DFT, we turned our attention to the choice of basis set, which might be expected to have a significant effect here. The model system involves two anions: the alkoxide and the sulfonate. As a result, it is reasonable to expect that diffuse functions might be important. Unfortunately, the system is quite large and suffered from numerical convergence issues when calculating frequencies. (Surprisingly, the energy and gradient calculations worked normally.) Both the 6$31+\mathrm{G}^{*}$ and jun-cc-pVDZ basis sets, which constitute very mild levels of augmentation, failed to converge. However, it was possible to place the diffuse functions of the 6$31+\mathrm{G}^{*}$ basis set on the alkoxide and sulfonate oxygens to create a "locally dense" basis set. In the archived files, this basis set is denoted as the custom basis.

We attempted to locate the analogous transition structures using the custom basis. Of the 29 transition structures found previously with 6-31G*, 22 analogous transition structures were found with the custom basis (the other 7 did not converge in geometry after repeated attempts):

\begin{tabular}{|c|r|r|c|r|}
\hline theory & forming & breaking & angle & imaginary \\
\cline { 1 - 5 } b1b95 & 2.529 & 2.219 & 135.909 & 108 \\
\cline { 1 - 5 } b3lyp_d3bj & $\mathbf{2 . 5 6 2}$ & $\mathbf{2 . 1 7 6}$ & $\mathbf{1 3 5 . 6 9 5}$ & $\mathbf{1 0 4}$ \\
\cline { 1 - 4 } & & &
\end{tabular}




\begin{tabular}{|c|c|c|c|c|}
\hline b971 & 2.584 & 2.279 & 130.793 & 67 \\
\hline b972 & 2.578 & 2.447 & 125.566 & 62 \\
\hline b97d & 2.660 & 2.120 & 140.002 & 134 \\
\hline b97d3 & 2.679 & 2.135 & 134.909 & 87 \\
\hline b98 & 2.579 & 2.285 & 131.179 & 68 \\
\hline bhandh & 2.328 & 2.075 & 144.351 & 260 \\
\hline bp86_d3bj & 2.563 & 2.126 & 138.328 & 124 \\
\hline cam_b3lyp_d3bj & 2.497 & 2.188 & 137.579 & 132 \\
\hline lcwpbe_d3bj & 2.429 & 2.180 & 140.747 & 184 \\
\hline $\mathrm{m} 062 x$ & 2.438 & 2.175 & 141.126 & 196 \\
\hline m062x_d3 & 2.440 & 2.165 & 140.689 & 212 \\
\hline m06_hf_d3 & 2.308 & 2.115 & 145.832 & 358 \\
\hline m061_d3 & 2.622 & 2.094 & 135.358 & 87 \\
\hline m11 & 2.489 & 2.132 & 141.717 & 194 \\
\hline mpw1pbe & 2.499 & 2.244 & 133.707 & 120 \\
\hline mpw1pw91 & 2.506 & 2.246 & 133.416 & 115 \\
\hline mpw3pbe & 2.520 & 2.240 & 133.561 & 118 \\
\hline n12sx & 2.514 & 2.197 & 135.993 & 151 \\
\hline pbe0_d3bj & 2.468 & 2.154 & 139.714 & 175 \\
\hline tpsstpss_d3bj & 2.558 & 2.092 & 139.374 & 130 \\
\hline
\end{tabular}

The computed KIEs were:

\begin{tabular}{|c|c|c|c|c|c|c|c|}
\hline theory & C1 & $\mathrm{C2}$ & C3 & C4 & C5 & C6 & HD \\
\hline b1b95 & 1.0310 & 1.0081 & 1.0017 & 1.0015 & 1.0065 & 0.9977 & 1.3278 \\
\hline b3lyp_d3bj & 1.0267 & 1.0075 & 1.0023 & 1.0022 & 1.0064 & 0.9984 & 1.3195 \\
\hline b971 & 1.0177 & 1.0086 & 1.0020 & 1.0019 & 1.0072 & 0.9990 & 1.3911 \\
\hline b972 & 1.0137 & 1.0104 & 1.0020 & 1.0014 & 1.0080 & 0.9988 & 1.6047 \\
\hline b97d & 1.0299 & 1.0049 & 1.0020 & 1.0028 & 1.0064 & 0.9969 & 1.2048 \\
\hline b97d3 & 1.0223 & 1.0064 & 1.0022 & 1.0023 & 1.0060 & 0.9978 & 1.3276 \\
\hline b98 & 1.0176 & 1.0087 & 1.0020 & 1.0019 & 1.0071 & 0.9989 & 1.3943 \\
\hline bhandh & 1.0647 & 1.0062 & 1.0026 & 1.0023 & 1.0041 & 0.9984 & 1.1277 \\
\hline bp86_d3bj & 1.0300 & 1.0065 & 1.0022 & 1.0024 & 1.0052 & 0.9981 & 1.3398 \\
\hline cam_b3lyp_d3bj & 1.0336 & 1.0082 & 1.0023 & 1.0018 & 1.0057 & 0.9984 & 1.2505 \\
\hline Icwpbe_d3bj & 1.0469 & 1.0085 & 1.0024 & 1.0012 & 1.0049 & 0.9986 & 1.2571 \\
\hline $\mathrm{m} 062 \mathrm{x}$ & 1.0488 & 1.0072 & 1.0028 & 1.0018 & 1.0050 & 0.9986 & 1.1226 \\
\hline m062x_d3 & 1.0497 & 1.0072 & 1.0031 & 1.0018 & 1.0046 & 0.9984 & 1.1700 \\
\hline m06_hf_d3 & 1.0775 & 1.0053 & 1.0024 & 1.0010 & 1.0018 & 0.9980 & 1.0203 \\
\hline m061_d3 & 1.0283 & 1.0072 & 1.0036 & 1.0021 & 1.0059 & 0.9978 & 1.4490 \\
\hline $\mathrm{m} 11$ & 1.0444 & 1.0063 & 1.0034 & 1.0016 & 1.0042 & 0.9984 & 1.1460 \\
\hline mpw1pbe & 1.0303 & 1.0097 & 1.0022 & 1.0015 & 1.0061 & 0.9984 & 1.4264 \\
\hline mpw1pw91 & 1.0290 & 1.0096 & 1.0022 & 1.0015 & 1.0063 & 0.9985 & 1.4277 \\
\hline mpw3pbe & 1.0287 & 1.0095 & 1.0021 & 1.0015 & 1.0061 & 0.9984 & 1.4273 \\
\hline
\end{tabular}




\begin{tabular}{|c|lllllll|} 
n12sx & 1.0357 & 1.0090 & 1.0025 & 1.0016 & 1.0049 & 0.9986 & 1.3010 \\
\cline { 1 - 5 } pbe0_d3bj & 1.0421 & 1.0080 & 1.0023 & 1.0015 & 1.0048 & 0.9980 & 1.2757 \\
\cline { 1 - 6 } tpsstpss_d3bj & 1.0315 & 1.0065 & 1.0023 & 1.0022 & 1.0044 & 0.9982 & 1.3165
\end{tabular}

In general, the transition states were looser. The forming bond length was somewhat longer:

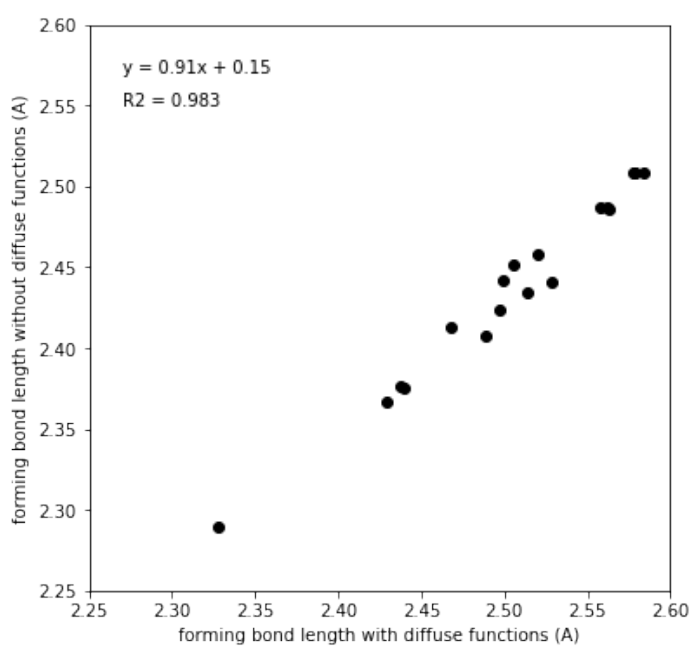

Figure S10. Breaking bond lengths increased with the addition of diffuse functions.

The breaking bond length was modestly increased as well:

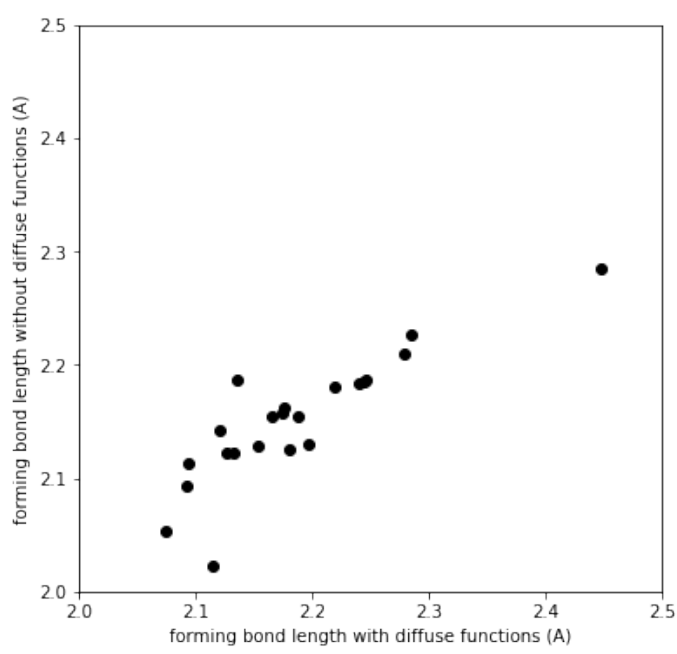

Figure S11. The forming bond lengths also increased with the addition of diffuse functions. 
There was also a striking dependence between the predicted KIE at $\mathrm{C} 1$ and the breaking bond length:

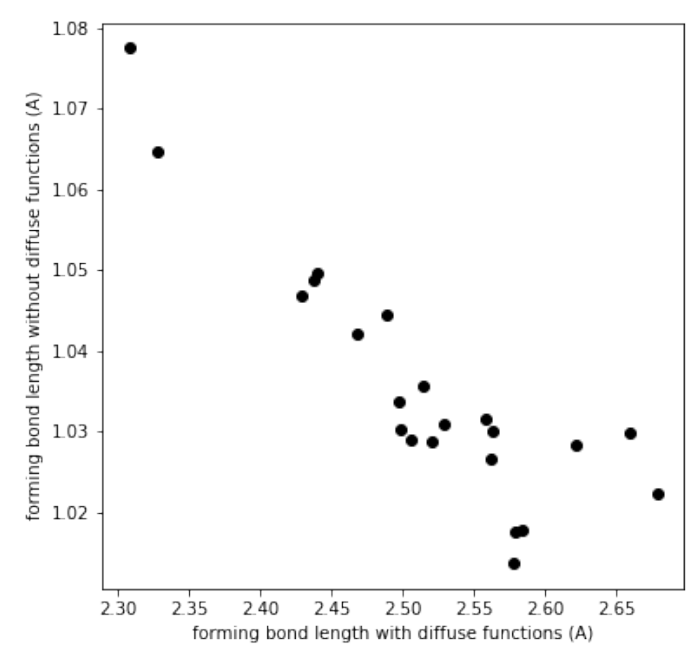

Figure S12. The KIE at $\mathrm{C} 1$ depends strongly on the forming bond length.

Interestingly, the geometries that were consistent with experiment remained in a similar region of the reaction coordinate (Figure S13). While B3LYP-D3(BJ) was within experimental error with the $6-31 \mathrm{G}^{*}$ basis set (1.036 predicted vs. $1.034 \pm 0.004$ experimental), it was modestly outside of experimental error with the custom basis set $(1.027 \pm 0.004)$. However, the geometries that reproduced experiment were from a very similar region of the reaction coordinate.

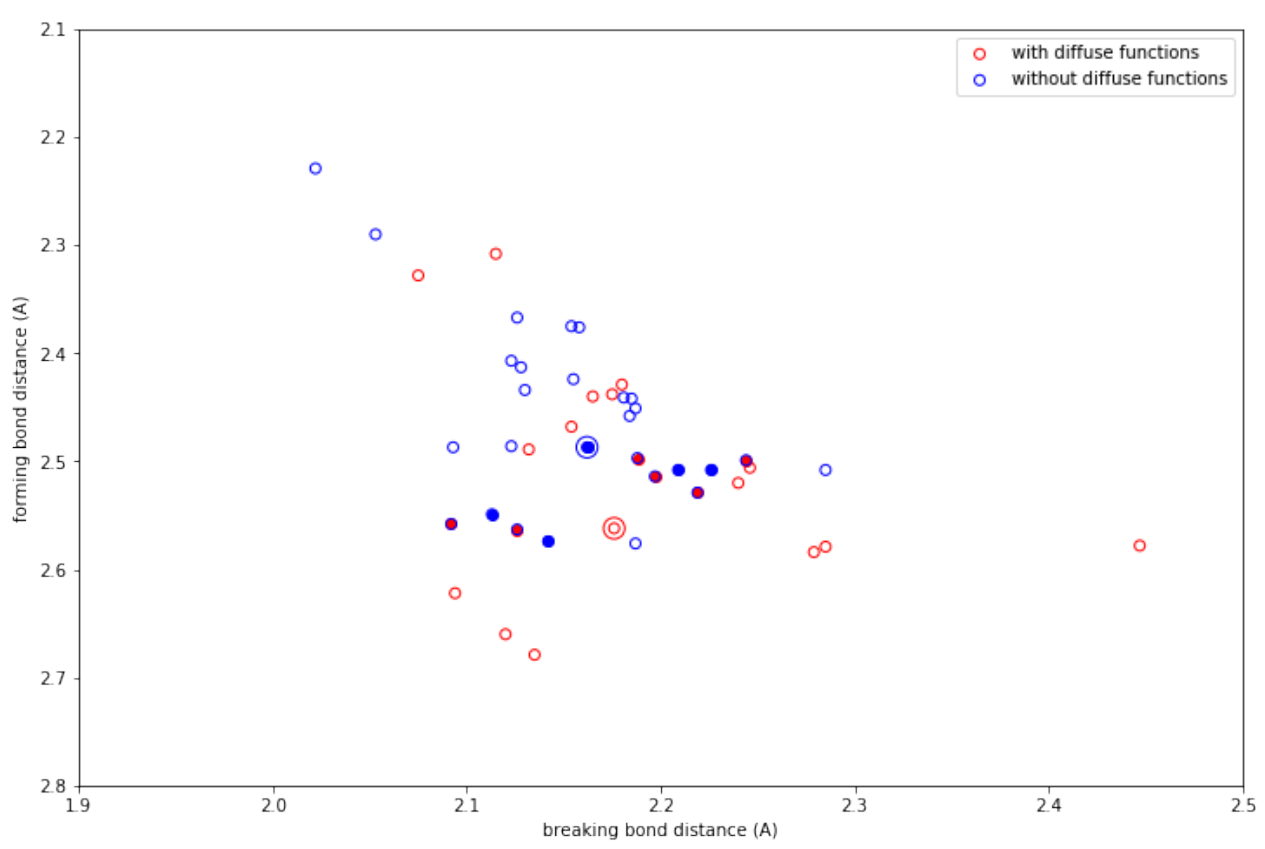

Figure S13. Agreement between transition structure and the experimental $\mathrm{KIE}$ at $\mathrm{C} 1$. Calculations with (red) and without (blue) diffuse functions 
gave structures in a similar region of the reaction coordinate. Some structures were consistent with experiment (solid circles), while many were not (open circles). Both basis sets gave agreement with experiment in a similar region of the reaction coordinate. The highlighted points denote B3LYP-D3(BJ).

\subsection{Lowest energy structure}

The following are coordinates for the lowest-energy transition structure (BCDR):

\begin{tabular}{|c|c|c|c|}
\hline C & -1.82206300 & 1.49821800 & 2.21782500 \\
\hline C & -2.11842700 & 2.32169300 & 0.96299600 \\
\hline $\mathrm{C}$ & -1.24282600 & 3.57667200 & 0.92527000 \\
\hline C & 0.49833200 & 2.51558900 & 2.21278700 \\
\hline C & -0.32125400 & 1.22428100 & 2.32556900 \\
\hline $\mathrm{H}$ & -1.34858400 & 4.08775900 & -0.04141600 \\
\hline $\mathrm{H}$ & -1.85126200 & 1.72940500 & 0.07977500 \\
\hline $\mathrm{H}$ & -2.15201400 & 2.06945800 & 3.09517400 \\
\hline $\mathrm{H}$ & 0.25689900 & 3.14815500 & 3.07671200 \\
\hline $\mathrm{H}$ & -0.05262400 & 0.54707700 & 1.50888800 \\
\hline O & 0.13031100 & 3.22143600 & 1.00134800 \\
\hline O & -1.62543500 & 4.42505900 & 1.97008200 \\
\hline O & -3.47916000 & 2.72023300 & 0.90347500 \\
\hline O & -2.55470600 & 0.27905700 & 2.12836000 \\
\hline O & -0.04341300 & 0.60557100 & 3.58045700 \\
\hline C & 2.01814400 & 2.29697600 & 2.15383600 \\
\hline $\mathrm{H}$ & 2.28455000 & 1.79993600 & 3.10999700 \\
\hline $\mathrm{H}$ & 2.46281200 & 3.31656200 & 2.22435500 \\
\hline O & 2.45361900 & 1.62507700 & 1.03522700 \\
\hline C & -4.28309200 & 1.89063600 & 0.07674700 \\
\hline $\mathrm{H}$ & -3.93472200 & 1.90708300 & -0.96582300 \\
\hline $\mathrm{H}$ & -4.28776500 & 0.85563800 & 0.43092400 \\
\hline $\mathrm{H}$ & -5.29792300 & 2.29516100 & 0.11387200 \\
\hline C & -3.08895400 & -0.17136200 & 3.36517000 \\
\hline $\mathrm{H}$ & -2.29736300 & -0.37793700 & 4.09276800 \\
\hline $\mathrm{H}$ & -3.77983000 & 0.57165400 & 3.78950100 \\
\hline $\mathrm{H}$ & -3.63925400 & -1.08899500 & 3.15183800 \\
\hline C & 0.74977300 & -0.57091900 & 3.47514300 \\
\hline $\mathrm{H}$ & 0.20312100 & -1.36551500 & 2.95424400 \\
\hline $\mathrm{H}$ & 1.68799000 & -0.38510200 & 2.94287400 \\
\hline $\mathrm{H}$ & 0.97023400 & -0.89498600 & 4.49586700 \\
\hline C & 3.82240200 & -1.51671200 & -1.33119500 \\
\hline $\mathrm{C}$ & 3.19719400 & -0.19854600 & -0.86528600 \\
\hline
\end{tabular}




\begin{tabular}{|c|c|c|c|}
\hline $\mathrm{C}$ & 1.84602000 & -0.41333100 & -0.25418600 \\
\hline $\mathrm{C}$ & 2.21083900 & -2.75110900 & 0.17331800 \\
\hline $\mathrm{C}$ & 3.67776600 & -2.53958300 & -0.19822800 \\
\hline $\mathrm{H}$ & 1.16342200 & 0.40357700 & -0.13706000 \\
\hline $\mathrm{H}$ & 3.78425000 & 0.20072900 & -0.02228900 \\
\hline & 3.30197000 & -1.86835600 & -2.22977400 \\
\hline $\mathrm{H}$ & 1.67508500 & -3.18410000 & -0.67630700 \\
\hline $\mathrm{H}$ & 4.21772800 & -2.16327700 & 0.67705800 \\
\hline 0 & 1.54084800 & -1.46617900 & 0.42563800 \\
\hline O & -0.51687100 & 0.19651100 & -3.88181900 \\
\hline O & 3.07200300 & 0.80972000 & -1.84746700 \\
\hline O & 5.19790800 & -1.29699800 & -1.59253900 \\
\hline 0 & 4.19017300 & -3.79824900 & -0.60044400 \\
\hline C & 1.97652100 & -3.59924600 & 1.40237300 \\
\hline $\mathrm{H}$ & 2.30022700 & -4.62570600 & 1.17636000 \\
\hline $\mathrm{H}$ & 0.89938700 & -3.62206300 & 1.62466100 \\
\hline & 2.70643800 & -3.05368900 & 2.48038700 \\
\hline$S$ & -0.29157500 & 0.03778900 & -2.43472300 \\
\hline 0 & -0.17851000 & 1.32244400 & -1.67512500 \\
\hline O & 0.83459600 & -0.91374800 & -2.09798900 \\
\hline C & -1.75146500 & -0.76810200 & -1.75948300 \\
\hline $\mathrm{C}$ & -2.99261400 & -0.56180500 & -2.35533500 \\
\hline $\mathrm{C}$ & -1.62481700 & -1.55665800 & -0.62016800 \\
\hline$C$ & -4.12143000 & -1.15333800 & -1.78772200 \\
\hline $\mathrm{H}$ & -3.07061900 & 0.04167700 & -3.25191700 \\
\hline C & -2.75900800 & -2.15274500 & -0.07467800 \\
\hline $\mathrm{H}$ & -0.65675600 & -1.70785600 & -0.16258500 \\
\hline C & -4.01209700 & -1.95419600 & -0.65027900 \\
\hline $\mathrm{H}$ & -4.89237600 & -2.41687400 & -0.22119700 \\
\hline $\mathrm{C}$ & 4.29999300 & 1.45303600 & -2.20679800 \\
\hline $\mathrm{H}$ & 4.92941200 & 1.61181900 & -1.32482600 \\
\hline $\mathrm{H}$ & 4.85315900 & 0.86325500 & -2.94165900 \\
\hline $\mathrm{H}$ & 4.02383700 & 2.41951200 & -2.63129200 \\
\hline C & 5.68701500 & -1.97950400 & -2.74339400 \\
\hline $\mathrm{H}$ & 5.54646100 & -3.06142200 & -2.65498000 \\
\hline $\mathrm{H}$ & 5.18749400 & -1.62270100 & -3.65499500 \\
\hline $\mathrm{H}$ & 6.75346600 & -1.75199100 & -2.80814600 \\
\hline $\mathrm{C}$ & 5.26386400 & -4.26732200 & 0.21284300 \\
\hline $\mathrm{H}$ & 6.12920200 & -3.59709500 & 0.14354700 \\
\hline 11 & 4.95628700 & -4.35332800 & 1.26261600 \\
\hline . & 5.53554100 & -5.25342600 & -0.16948900 \\
\hline C & 2.48404200 & -3.75720400 & 3.69286800 \\
\hline $\mathrm{H}$ & 3.08211700 & -3.26350000 & 4.46116900 \\
\hline & 1.42384000 & -3.72458200 & 3.98126500 \\
\hline
\end{tabular}




$\begin{array}{lrrr}\mathrm{H} & 2.79582400 & -4.80813000 & 3.60728400 \\ \mathrm{C} & -0.97469900 & 5.69050100 & 1.93425100 \\ \mathrm{H} & -1.41196100 & 6.29180800 & 2.73360500 \\ \mathrm{H} & 0.10450300 & 5.59172100 & 2.09828000 \\ \mathrm{H} & -1.14441500 & 6.18927000 & 0.96915000 \\ \mathrm{Na} & 1.53637400 & 2.64926800 & -0.81633100 \\ \mathrm{O} & 3.07159800 & 4.33269300 & -1.04929100 \\ \mathrm{C} & 3.17165200 & 5.49656500 & -1.85429700 \\ \mathrm{H} & 4.11767200 & 5.50588700 & -2.41357500 \\ \mathrm{H} & 2.33551300 & 5.47845100 & -2.55702300 \\ \mathrm{H} & 3.11273400 & 6.40624600 & -1.24075800 \\ \mathrm{C} & 4.11206700 & 4.23210000 & -0.07873000 \\ \mathrm{H} & 4.07886300 & 5.08515900 & 0.61259900 \\ \mathrm{H} & 3.93329800 & 3.29770800 & 0.45992100 \\ \mathrm{H} & 5.09486800 & 4.20842000 & -0.56988800 \\ \mathrm{C} & -5.47954000 & -0.86784900 & -2.36621100 \\ \mathrm{~F} & -6.03096300 & 0.23884600 & -1.80663300 \\ \mathrm{~F} & -6.34293000 & -1.88310000 & -2.15278600 \\ \mathrm{~F} & -5.42503400 & -0.64719300 & -3.69571500 \\ \mathrm{C} & -2.60302000 & -3.08614400 & 1.09250200 \\ \mathrm{~F} & -1.59198400 & -2.71351300 & 1.91268800 \\ \mathrm{~F} & -2.31999300 & -4.34514600 & 0.68349000 \\ \mathrm{~F} & -3.72646300 & -3.15965100 & 1.83989300\end{array}$

\subsection{Conclusion}

Overall, our interpretation is that most commonly-used computational methods can reproduce the experimental KIEs, although the both the choice of DFT and basis set are important. The effect of the choice of DFT can be ascribed to the numerous noncovalent interactions in this system, as well as electron correlation effects in the partially formed or broken bonds. The effect of basis set is likely basis set superposition error. In turn, these effects create a range of predictions for the KIE at C1. However, the region of the reaction coordinate that agrees with experiment is remarkably small and independent of basis set. (This analysis only considered one template transition structure, so whether this is also independent of DFT choice cannot be determined.) Furthermore, B3LYP-D3(BJ) gives transition structures that are average when compared with the transition structures given by other DFTs. Thus, while the agreement with experiment obtained with B3LYP-D3(BJ)/6-31G* is likely due in part to the cancellation of errors, the predicted transition structure is meaningful and is similar to what would be predicted by other functionals in the same region of the reaction coordinate. 


\section{References}

[1] D. Waschke, J. Thimm, J. Thiem, Org. Lett. 2011, 13, 3628-3631.

[2] J. Y. Baek, H.-W. Kwon, S. J. Myung, J. J. Park, M. Y. Kim, D. C. K. Rathwell, H. B. Jeon, P. H. Seeberger, K. S. Kim, Tetrahedron 2015, 71, 5315-5320.

[3] J. Dinkelaar, L. J. van den Bos, W. F. J. Hogendorf, G. Lodder, H. S. Overkleeft, J. D. C. Codée, G. A. van der Marel, Chem. Eur. J. 2008, 14, 9400-9411.

[4] E. Sasaki, C.-I. Lin, K.-Y. Lin, H.-w. Liu, J. Am. Chem. Soc. 2012, 134, 1743217435.

[5] G. Sennari, T. Hirose, M. Iwatsuki, S. Omura, T. Sunazuka, Chem. Comm. 2014, $50,8715-8718$.

[6] a) H. Xu, Y. Lu, Y. Zhou, B. Ren, Y. Pei, H. Dong, Z. Pei, Adv. Synth. Catal. 2014, 356, 1735-1740; b) J. Xue, Z. Guo, J. Carbohydr. Chem. 2008, 27, 51-69.

[7] a) D. Lloyd, M. Bylsma, D. K. Bright, X. Chen, C. S. Bennett, J. Org. Chem. 2017, 82, 3926-3934; b) L. Liu, J. Zha, A. DiGiandomenico, D. McAllister, C. K. Stover, Q. Wang, G.-J. Boons, Angew. Chem. Int. Ed. 2015, 54, 10953-10957.

[8] G. Tseberlidis, P. Zardi, A. Caselli, D. Cancogni, M. Fusari, L. Lay, E. Gallo, Organometallics 2015, 34, 3774-3781.

[9] M. Boultadakis-Arapinis, P. Lemoine, S. Turcaud, L. Micouin, T. Lecourt, $J$. Am. Chem. Soc. 2010, 132, 15477-15479.

[10] H. Liu, X. Li, J. Org. Chem. 2014, 79, 5834-5841.

[11] C.-S. Chao, C.-Y. Lin, S. Mulani, W.-C. Hung, K.-k. T. Mong, Chem. Eur. J. 2011, 17, 12193-12202.

[12] A.-H. A. Chu, S. H. Nguyen, J. A. Sisel, A. Minciunescu, C. S. Bennett, Org. Lett. 2013, 15, 2566-2569.

[13] S. Kaeothip, J. P. Yasomanee, A. V. Demchenko, J. Org. Chem. 2012, 77, 291299.

[14] A. M. Vibhute, A. Dhaka, V. Athiyarath, K. M. Sureshan, Chem. Sci. 2016, 7, 4259-4263.

[15] H. Chiba, S. Funasaka, T. Mukaiyama, Bull. Chem. Soc. Jpn. 2003, 76, 16291644.

[16] a) L. Sun, X. Wu, D.-C. Xiong, X.-S. Ye, Angew. Chem. Int. Ed. 2016, 55, 80418044; b) H. Nagai, K. Sasaki, S. Matsumura, K. Toshima, Carbohydr. Res. 2005, 340, 337-353.

[17] K.-T. Huang, N. Winssinger, Eur. J. Org. Chem. 2007, 2007, 1887-1890.

[18] M.-j. Xia, W. Yao, X.-b. Meng, Q.-h. Lou, Z.-j. Li, Tetrahedron Lett. 2017, 58, 2389-2392.

[19] D.-C. Xiong, L.-H. Zhang, X.-S. Ye, Adv. Syn. Catal. 2008, 350, 1696-1700.

[20] D. Crich, M. de la Mora, A. U. Vinod, J. Org. Chem. 2003, 68, 8142-8148.

[21] A.-H. A. Chu, A. Minciunescu, V. Montanari, K. Kumar, C. S. Bennett, Org. Lett. 2014, 16, 1780-1782.

[22] K. C. H. Yongho Park, Nadine Kuhl, Eugene E. Kwan, Richard Y. Liu, Eric N. Jacobsen Science 2017, 355, 162-166. 
[23] a) G. S. Jones, W. J. Scott, J. Am. Chem. Soc. 1992, 114, 1491-1492; b) D. J. Chambers, G. R. Evans, A. J. Fairbanks, Tetrahedron 2004, 60, 8411-8419.

[24] W. von E. Doering, R. S. Urban, J. Am. Chem. Soc. 1956, 78, 5938-5942.

[25] E. E. Kwan, Y. Park, H. A. Besser, T. L. Anderson, E. N. Jacobsen, J. Am. Chem. Soc. 2017, 139, 43-46.

[26] E. E. Kwan, Y. Zeng, H. A. Besser, E. N. Jacobsen, Nat Chem 2018, 10, $917-$ 923.

[27] Bell, R.P. Trans. Faraday Soc. 1959, 55, 1-4. 


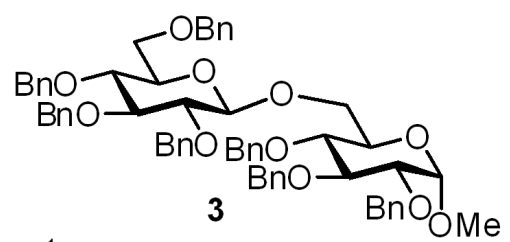

${ }^{1} \mathrm{H} \mathrm{NMR}\left(500 \mathrm{MHz}, \mathrm{CDCl}_{3}\right)$

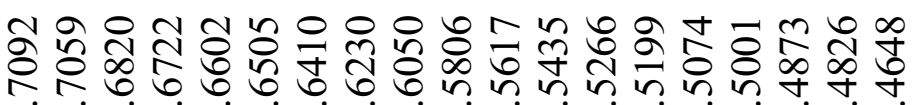

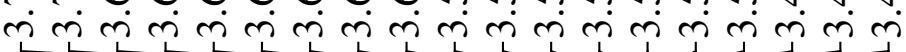

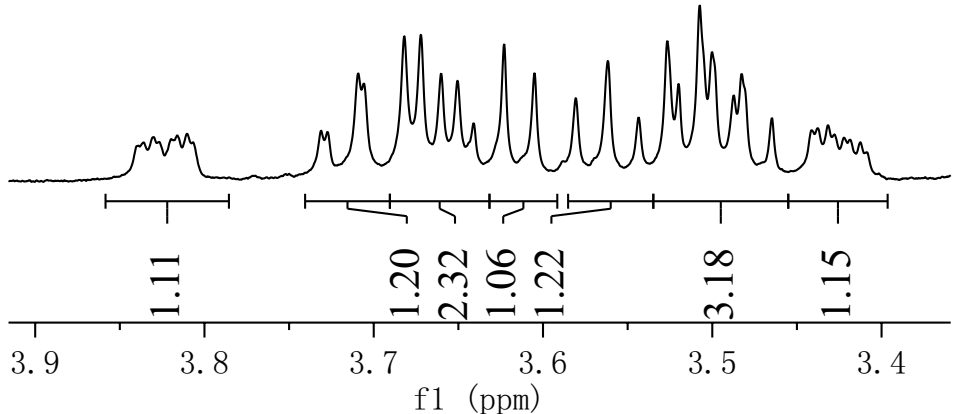

f1 (ppm)

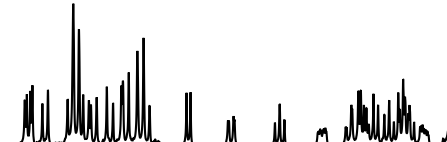

бㅇำ

(1)

$0 \quad 4.5$

4. $0 \quad 3.5$

3. 0

$2.5 \quad 2.0 \quad 1.5$

1. 0

0.5

0.0 


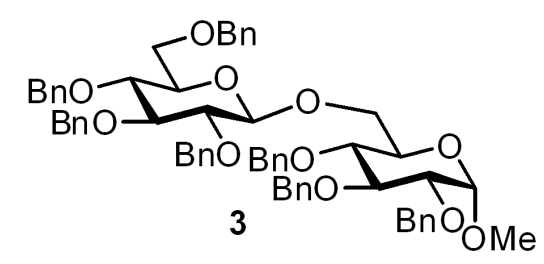

${ }^{13} \mathrm{C}$ NMR $\left(125 \mathrm{MHz}, \mathrm{CDCl}_{3}\right)$

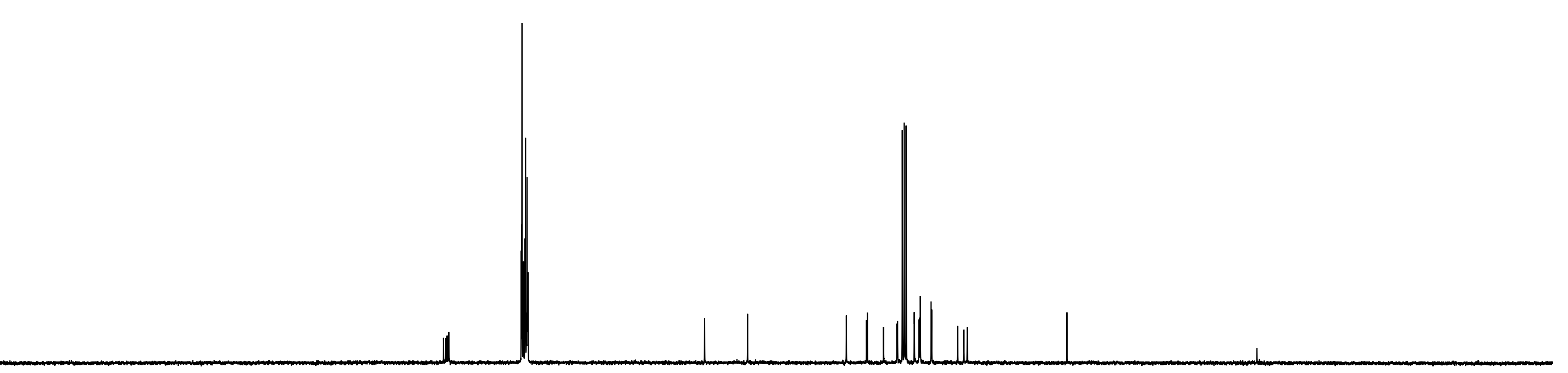

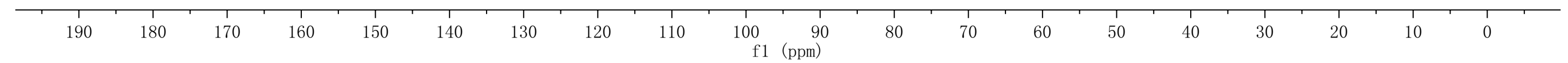



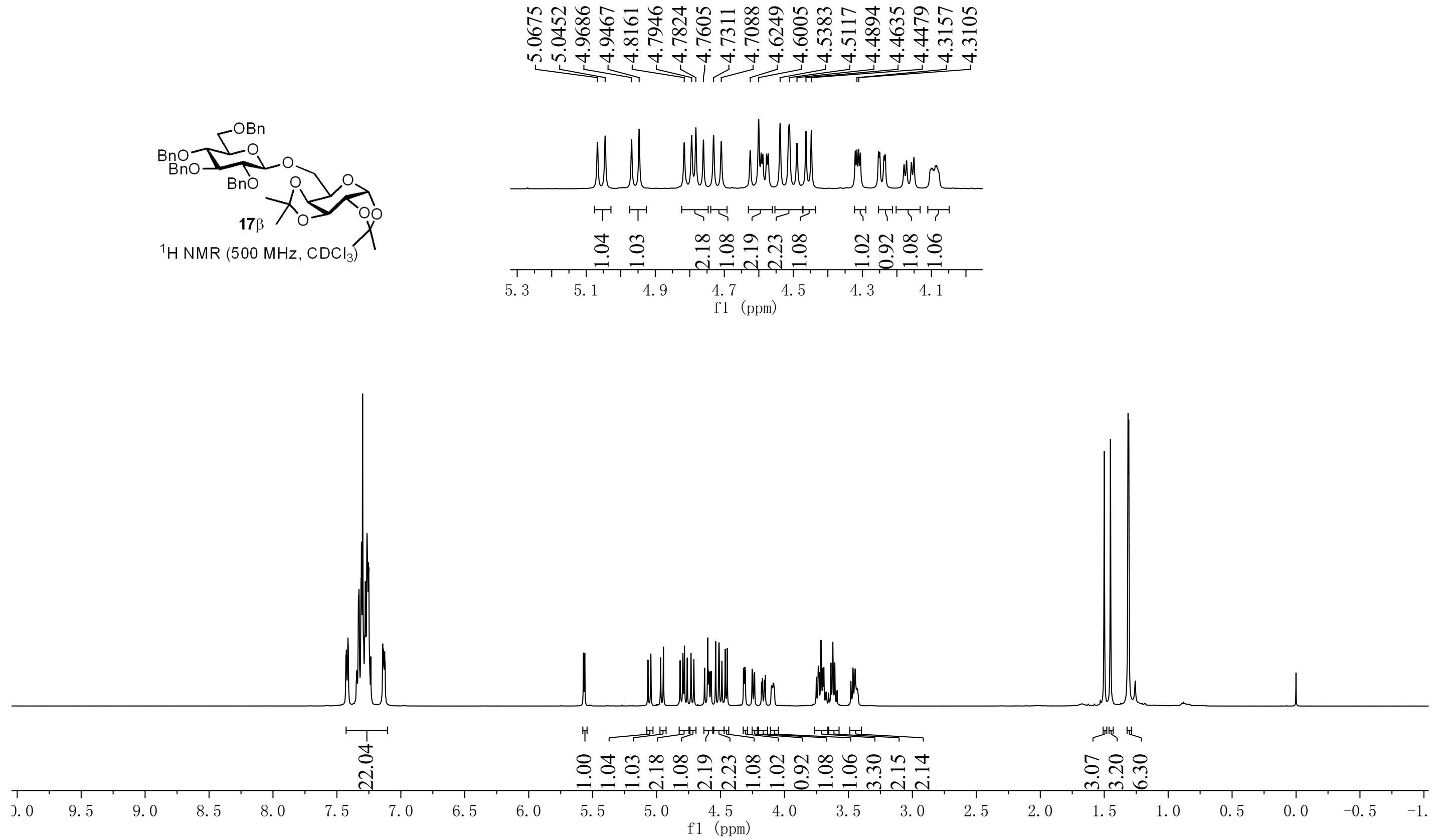


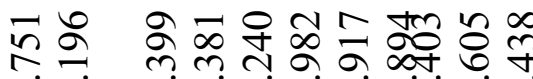

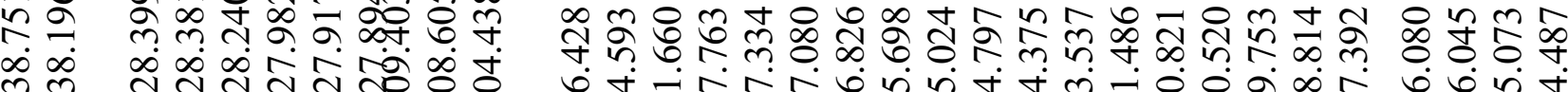

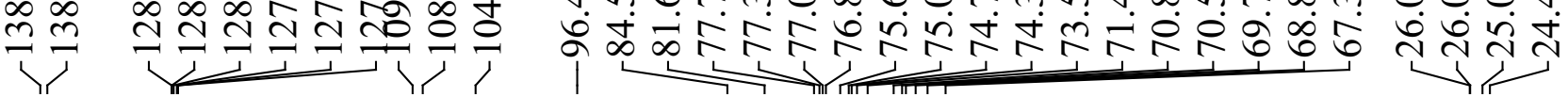

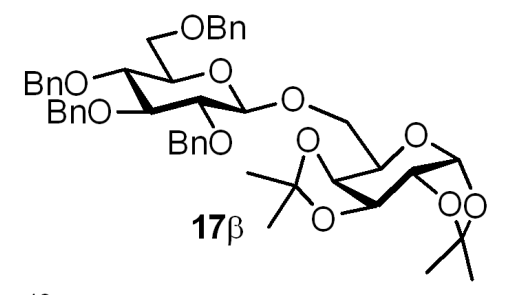

${ }^{13} \mathrm{C} \mathrm{NMR}\left(125 \mathrm{MHz}, \mathrm{CDCl}_{3}\right)$

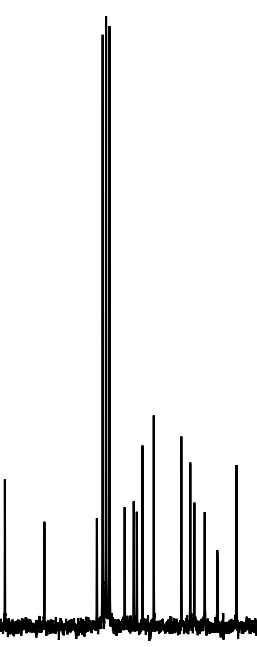




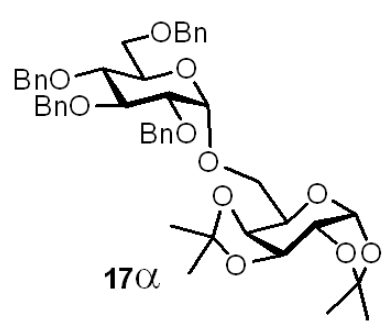

${ }^{1} \mathrm{HNMR}\left(500 \mathrm{MHz}, \mathrm{CDCl}_{3}\right)$

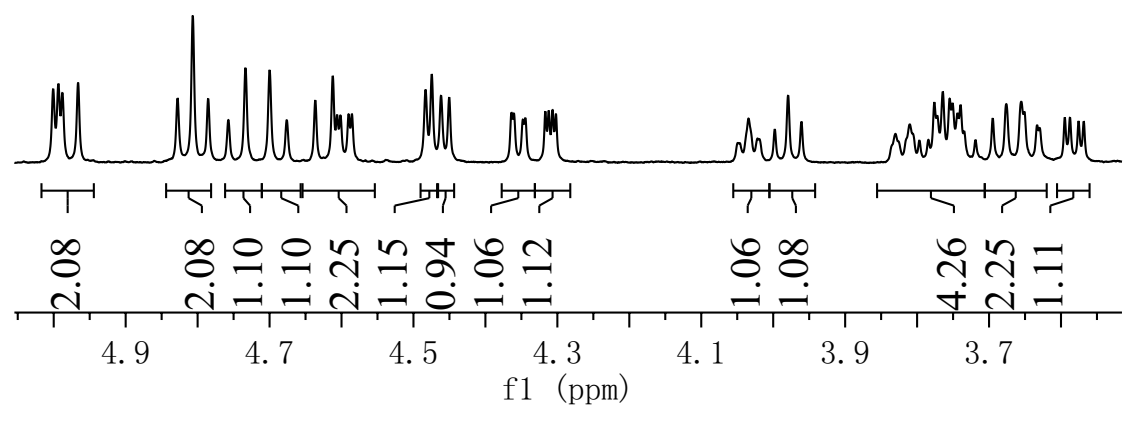

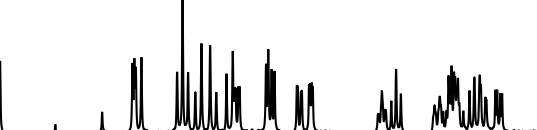

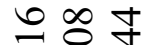

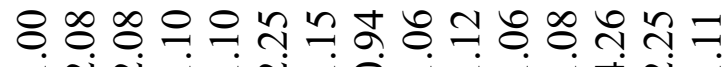
mi

$\begin{array}{lllll}.5 & 9.0 & 8.5 & 8.0 & 7.5\end{array}$

$7.0 \quad 6.5$

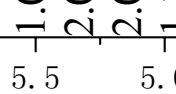




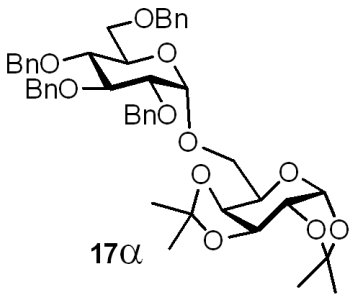

${ }^{13} \mathrm{C} \mathrm{NMR}\left(125 \mathrm{MHz}, \mathrm{CDCl}_{3}\right)$

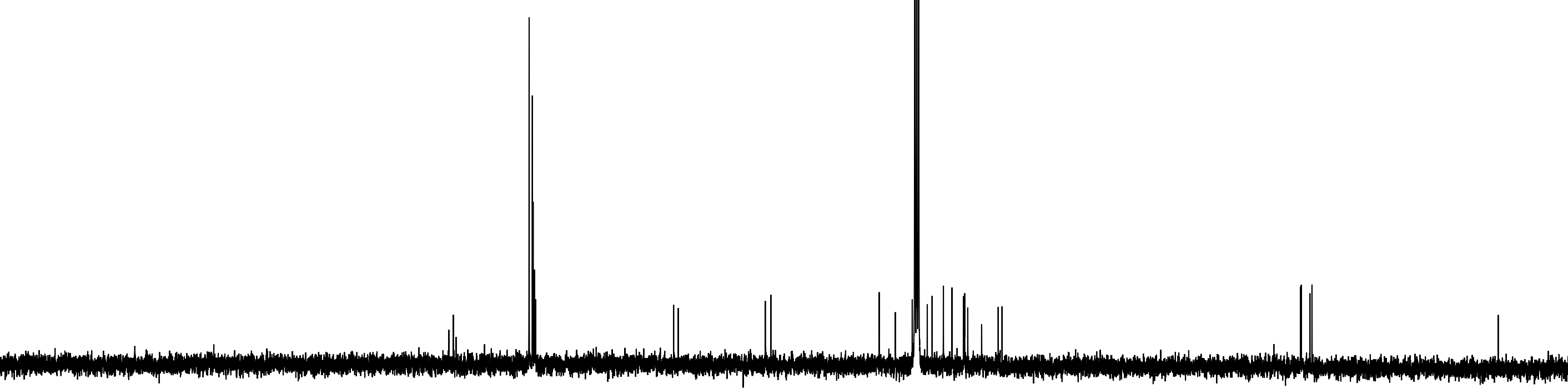

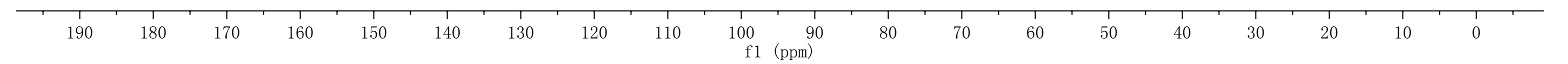




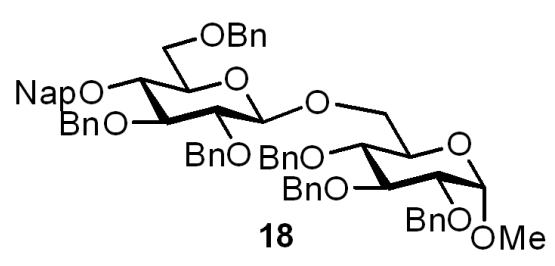

${ }^{1} \mathrm{HNMR}\left(500 \mathrm{MHz}, \mathrm{CDCl}_{3}\right)$
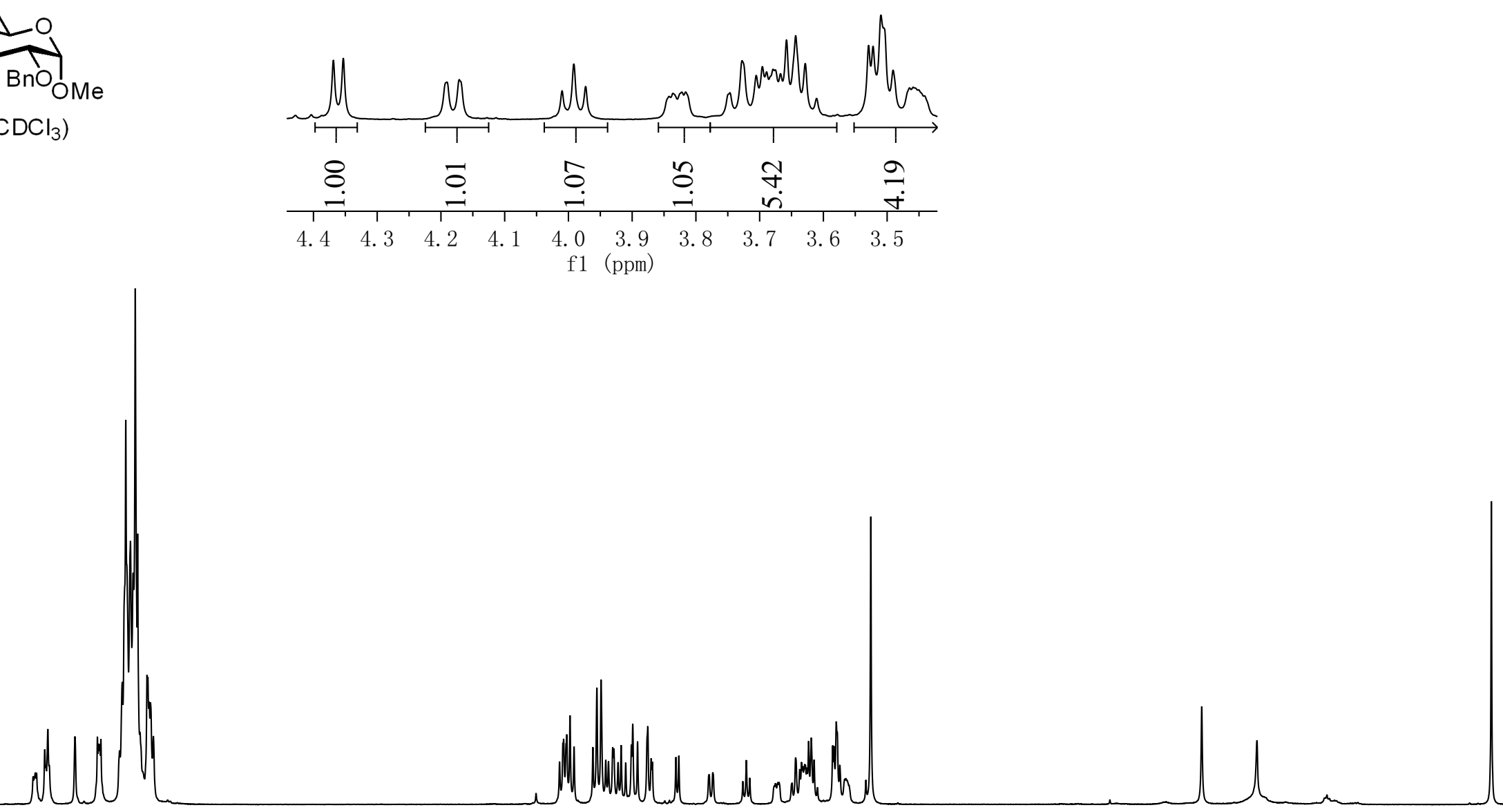

ग卌!

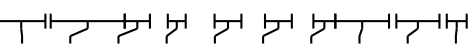

ํํำ?ำ?

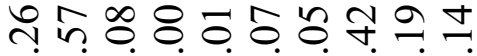

mo, तim, , , , , , , , , ,



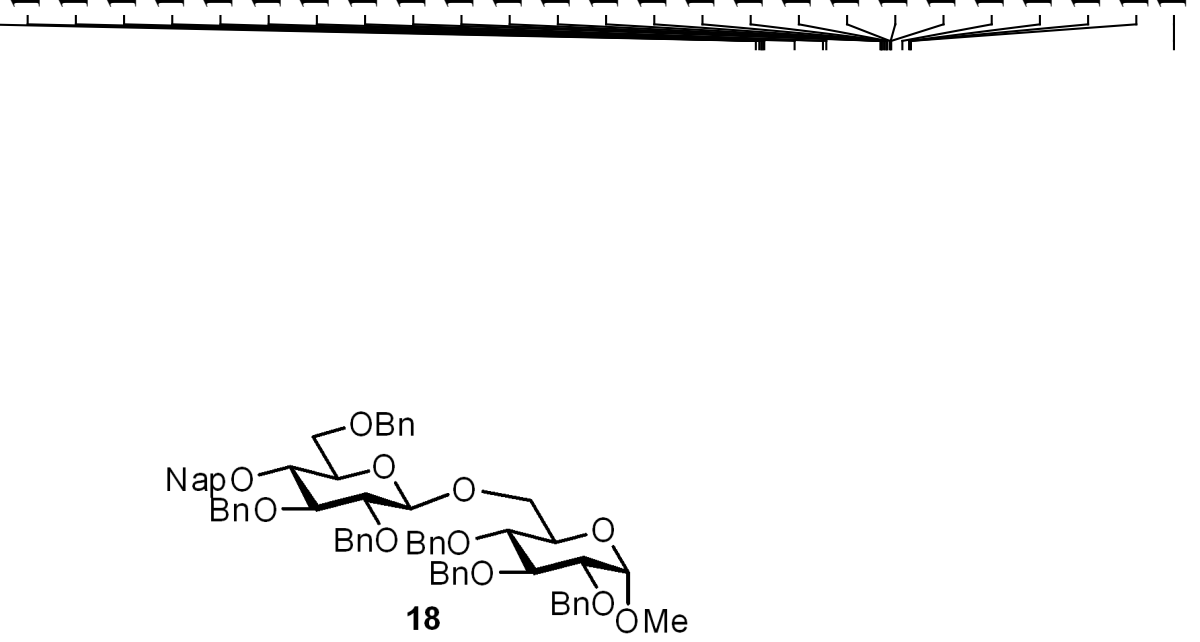

${ }^{13} \mathrm{C} \mathrm{NMR}\left(125 \mathrm{MHz}, \mathrm{CDCl}_{3}\right)$

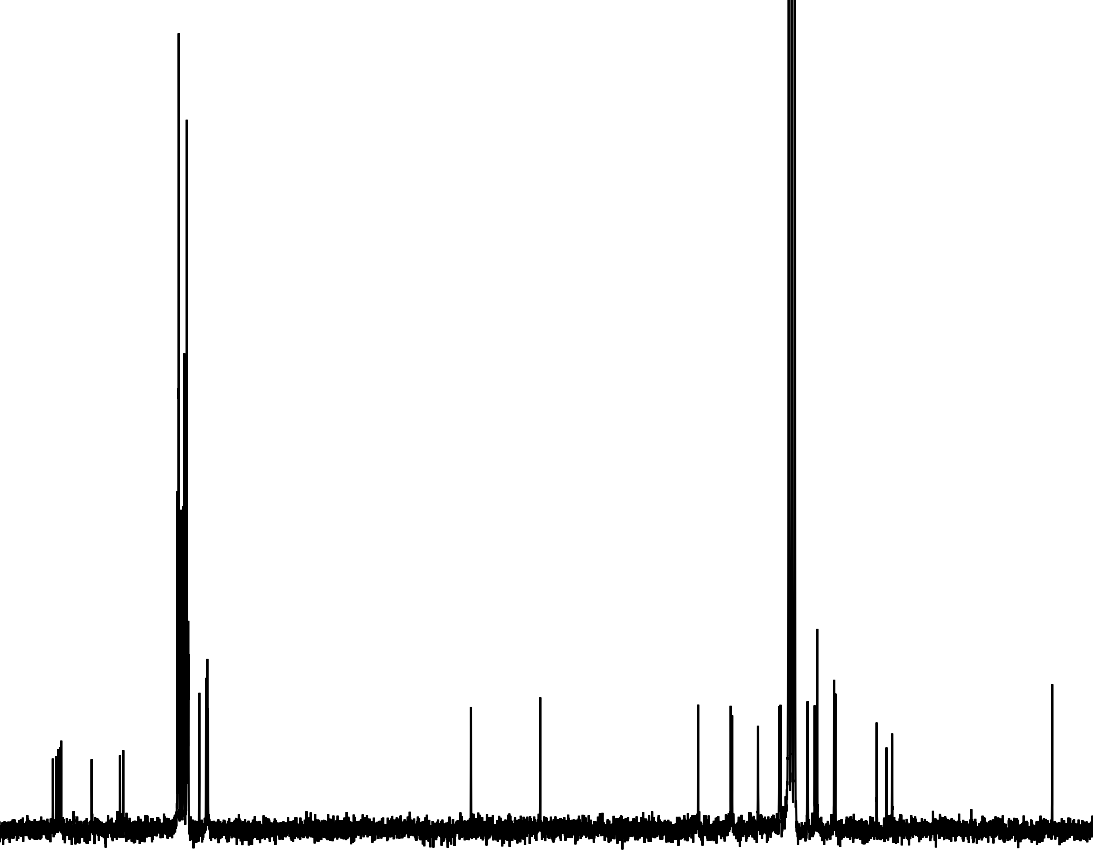

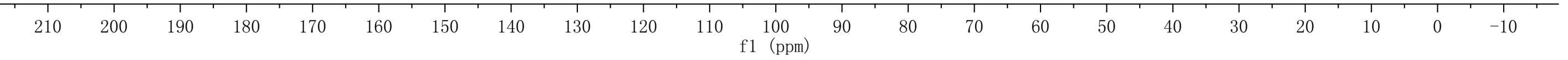



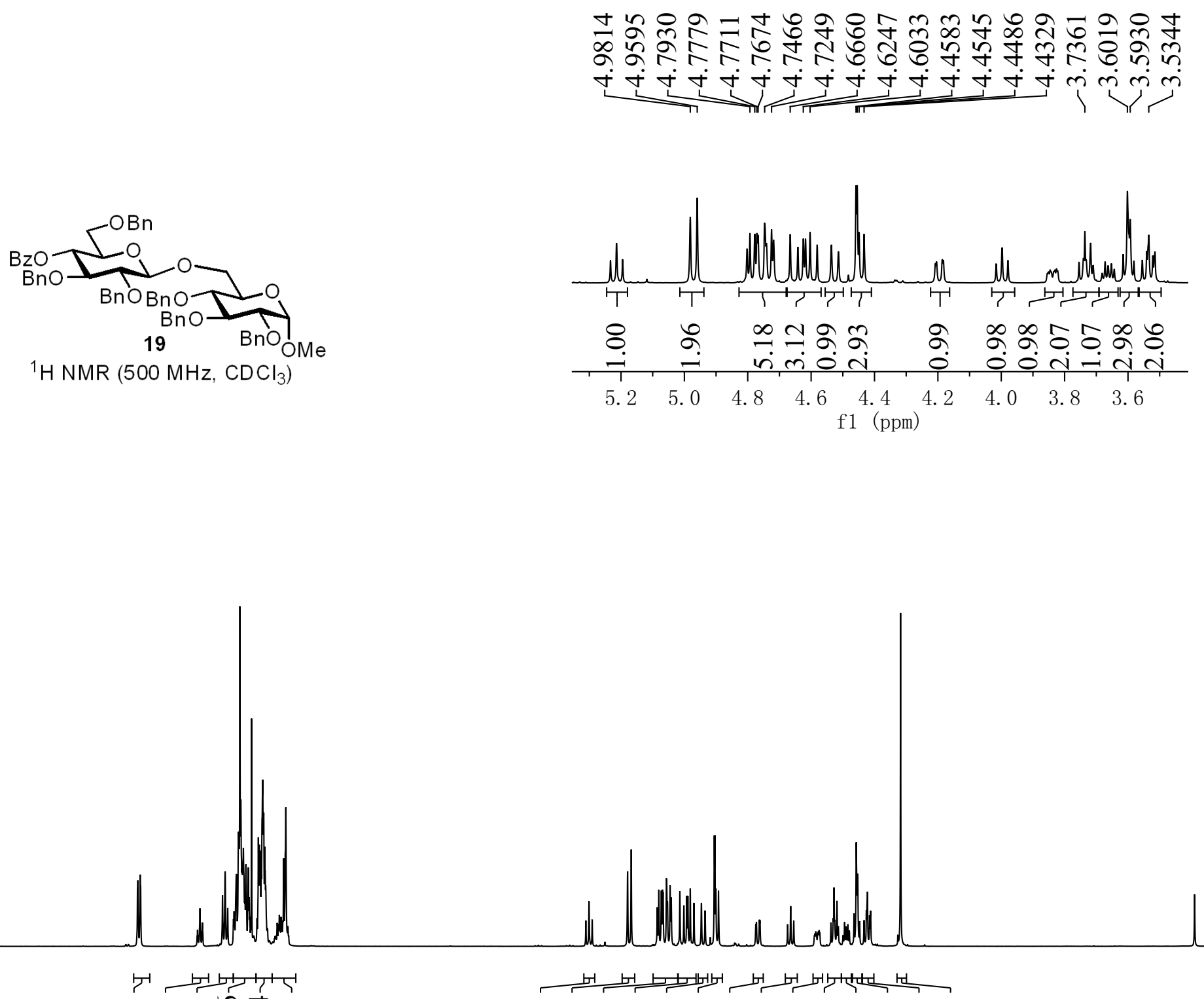

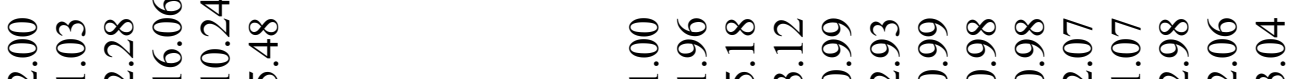

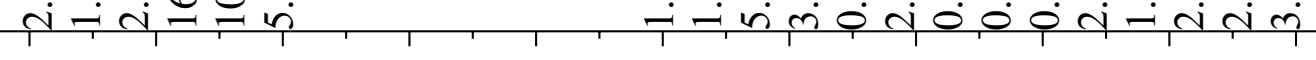

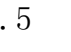

7. 0 6.

$$
\text { f1 (ppm) }
$$




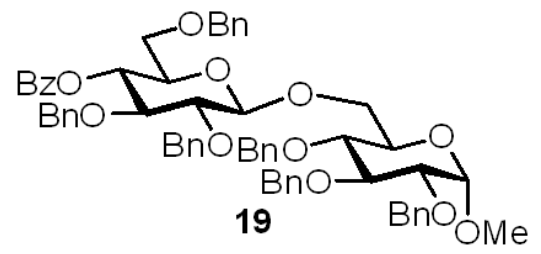

${ }^{13} \mathrm{C} \mathrm{NMR}\left(125 \mathrm{MHz}, \mathrm{CDCl}_{3}\right)$

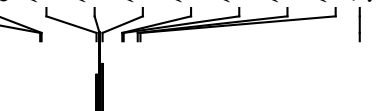

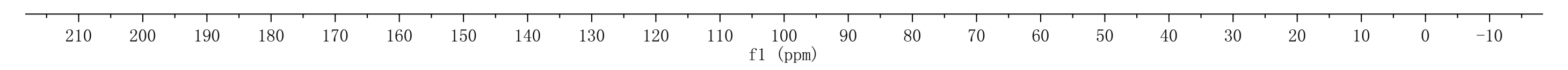



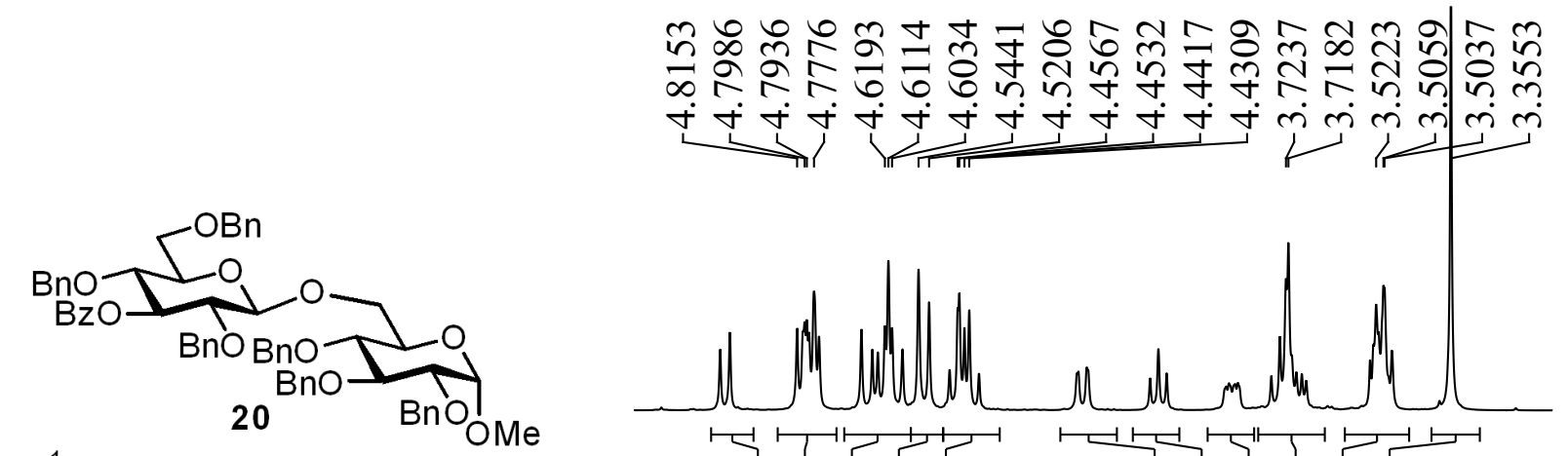

${ }^{1} \mathrm{H} \mathrm{NMR}\left(500 \mathrm{MHz}, \mathrm{CDCl}_{3}\right)$
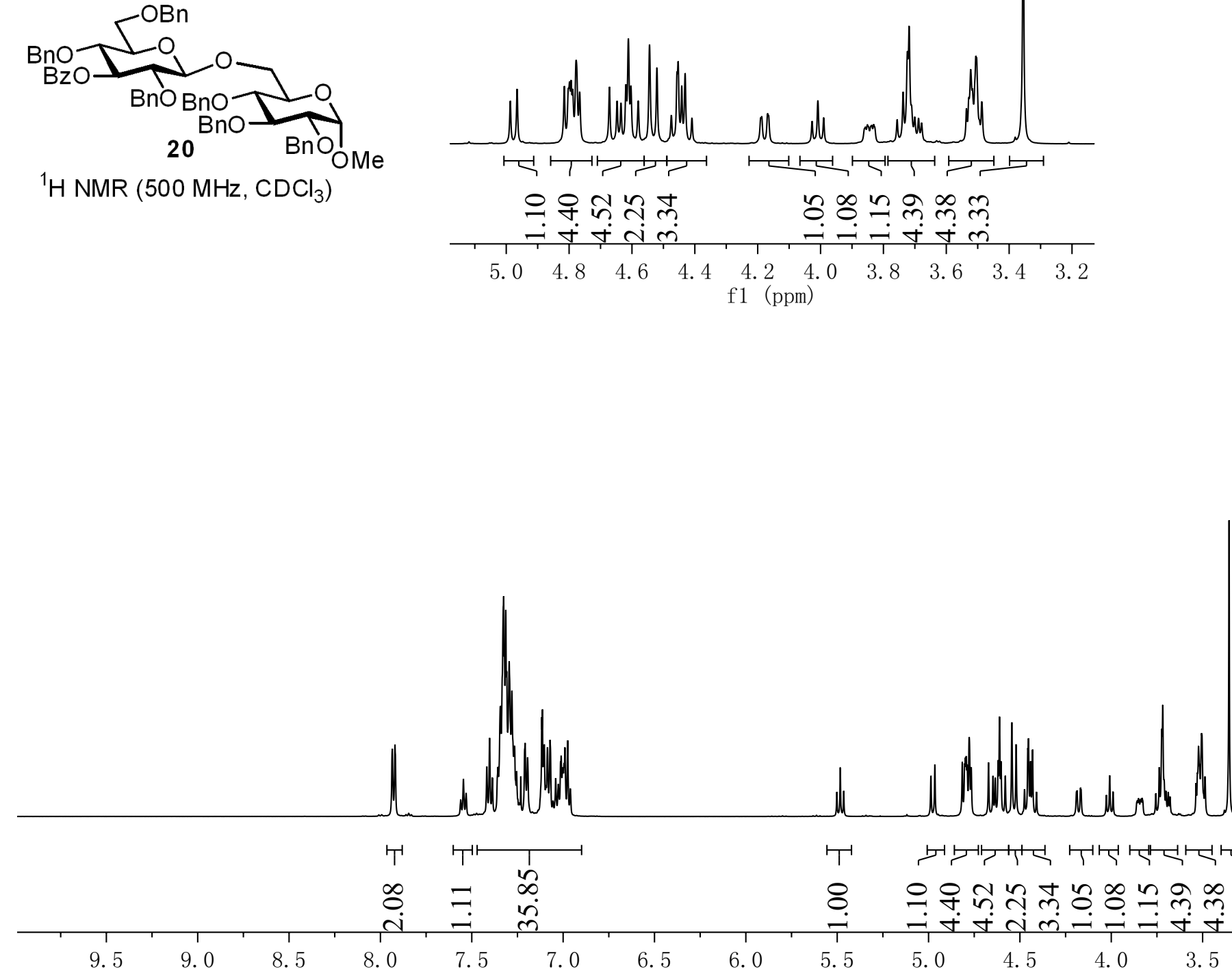

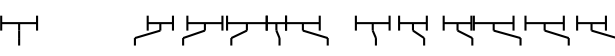

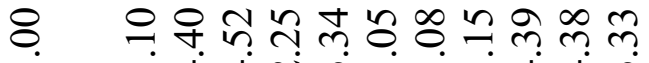




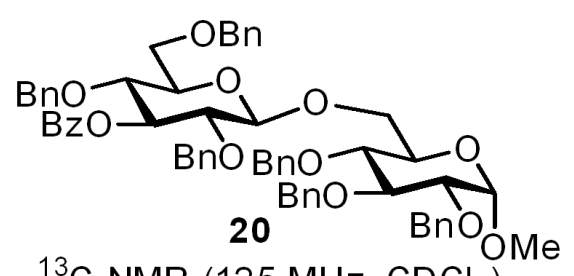

${ }^{13} \mathrm{C} \mathrm{NMR}\left(125 \mathrm{MHz}, \mathrm{CDCl}_{3}\right)$

\begin{tabular}{|c|c|c|c|c|c|c|c|c|c|c|c|c|c|c|c|c|c|c|c|c|c|c|}
\hline 210 & 200 & $\begin{array}{l}1 \\
190\end{array}$ & $\begin{array}{l}1 \\
180\end{array}$ & $\begin{array}{l}1 \\
170\end{array}$ & $\begin{array}{l}160 \\
160\end{array}$ & 150 & 140 & $\begin{array}{l}1 \\
130\end{array}$ & $\begin{array}{l}1 \\
120\end{array}$ & 110 & $\begin{array}{c}100 \\
\text { f1 }(\mathrm{ppm})\end{array}$ & 90 & $\begin{array}{l}1 \\
80\end{array}$ & 70 & 60 & 50 & 10 & 30 & 20 & 10 & 0 & $\begin{array}{c}1 \\
-10\end{array}$ \\
\hline
\end{tabular}




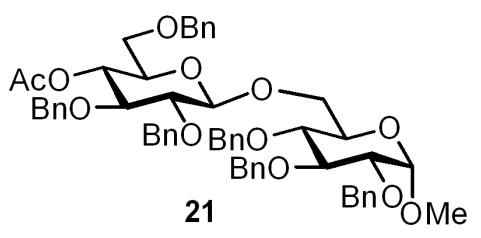

${ }^{1} \mathrm{H}$ NMR $\left(500 \mathrm{MHz}, \mathrm{CDCl}_{3}\right)$

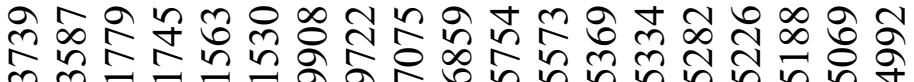

m.

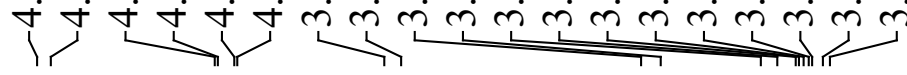
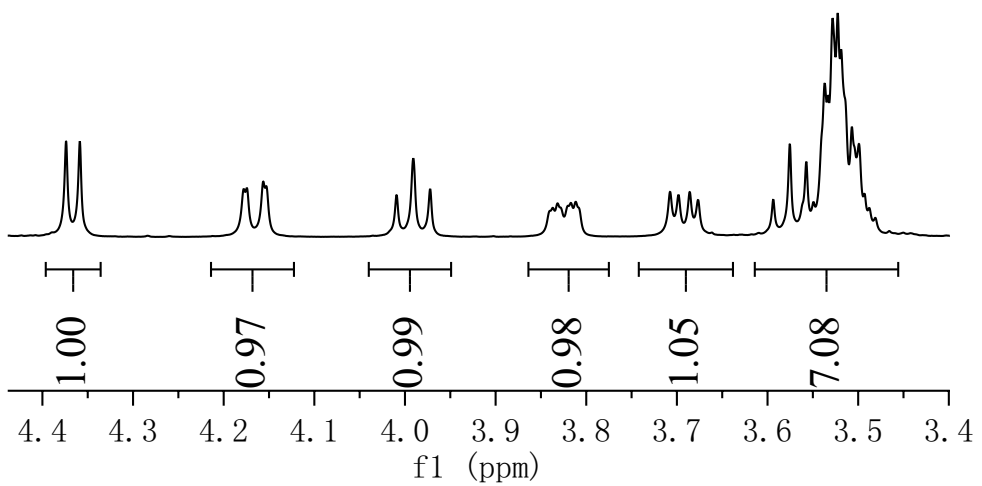

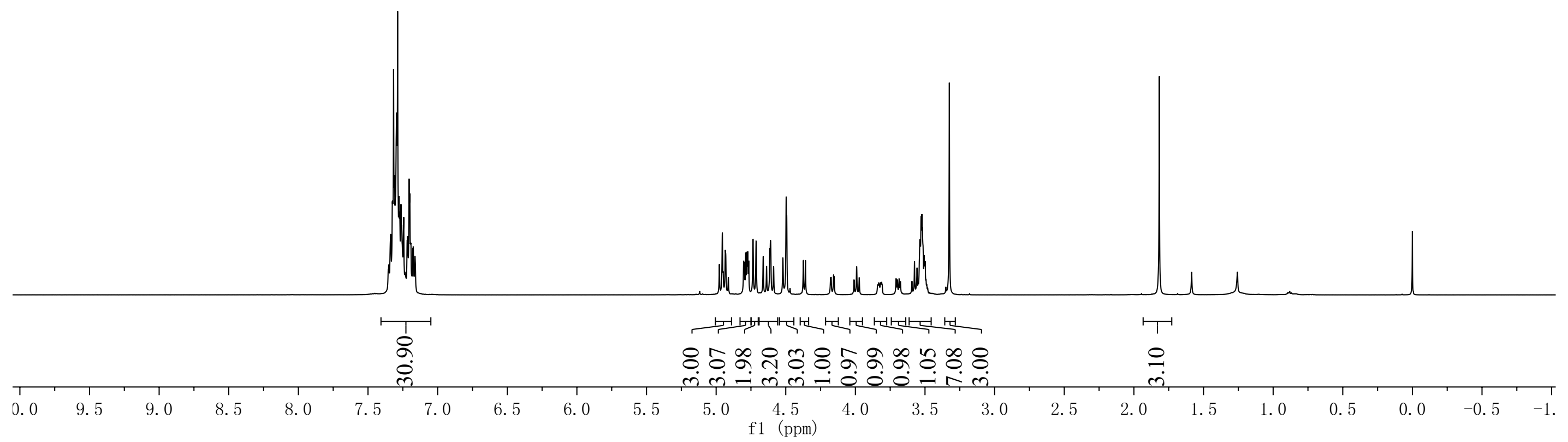




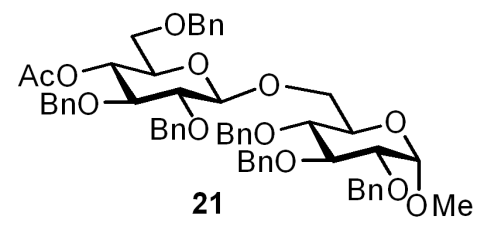

${ }^{13} \mathrm{C} \mathrm{NMR}\left(125 \mathrm{MHz}, \mathrm{CDCl}_{3}\right)$

\begin{tabular}{|c|c|c|c|c|c|c|c|c|c|c|c|c|c|c|c|c|c|c|c|c|c|c|}
\hline 210 & 200 & 190 & 180 & 170 & 160 & 150 & 140 & 130 & 120 & 110 & 100 & 90 & 80 & 70 & 60 & 50 & 40 & 30 & 20 & 10 & 0 & -10 \\
\hline
\end{tabular}




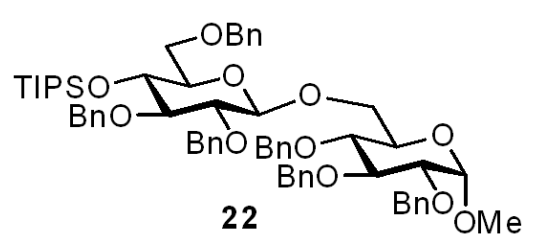

${ }^{1} \mathrm{H} \mathrm{NMR}\left(500 \mathrm{MHz}, \mathrm{CDCl}_{3}\right)$
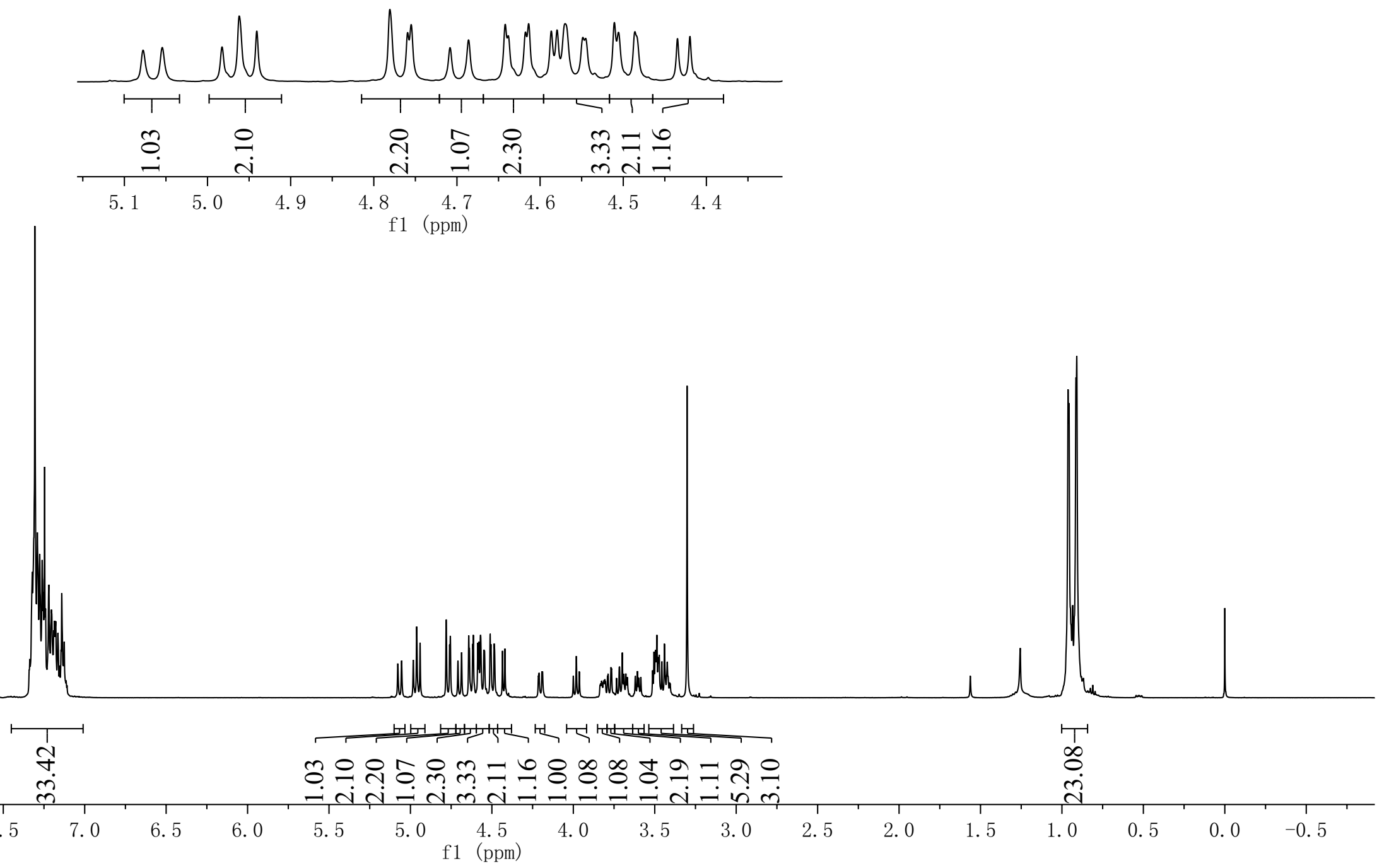


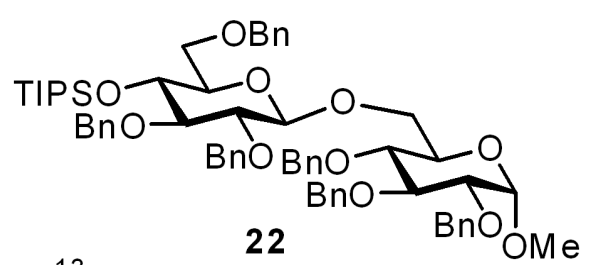

${ }^{13} \mathrm{C}$ NMR $\left(125 \mathrm{MHz}, \mathrm{CDCl}_{3}\right)$

$$
\text { ) }
$$




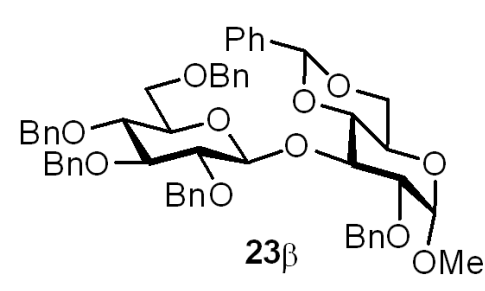

${ }^{1} \mathrm{HNMR}\left(500 \mathrm{MHz}, \mathrm{CDCl}_{3}\right)$

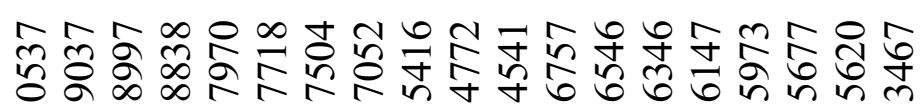

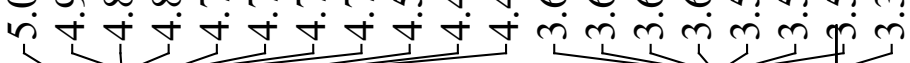
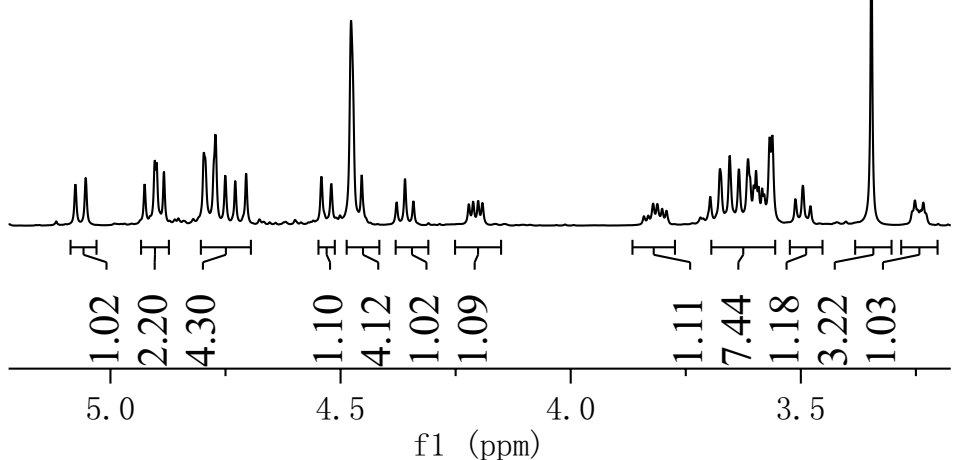

f1 (ppm)

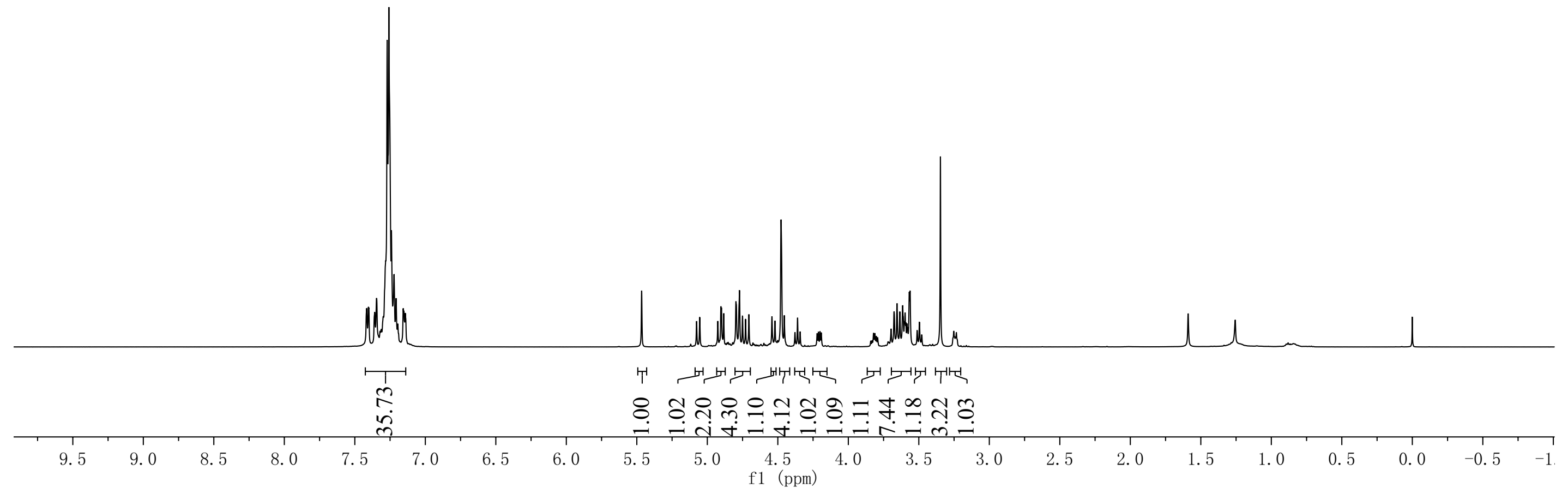




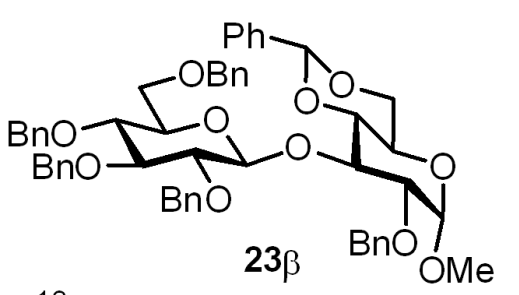

${ }^{13} \mathrm{C}$ NMR $\left(125 \mathrm{MHz}, \mathrm{CDCl}_{3}\right)$

\begin{tabular}{|c|c|c|c|c|c|c|c|c|c|c|c|c|c|c|c|c|c|c|c|}
\hline 190 & 180 & 170 & 160 & 150 & 140 & 130 & 120 & 110 & 100 & $\begin{array}{r}90 \\
(\mathrm{ppm})\end{array}$ & 80 & 70 & 60 & 50 & 40 & 30 & 20 & 10 & 0 \\
\hline
\end{tabular}




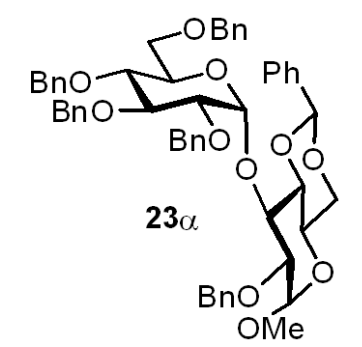

${ }^{1} \mathrm{H} \mathrm{NMR}\left(500 \mathrm{MHz}, \mathrm{CDCl}_{3}\right)$
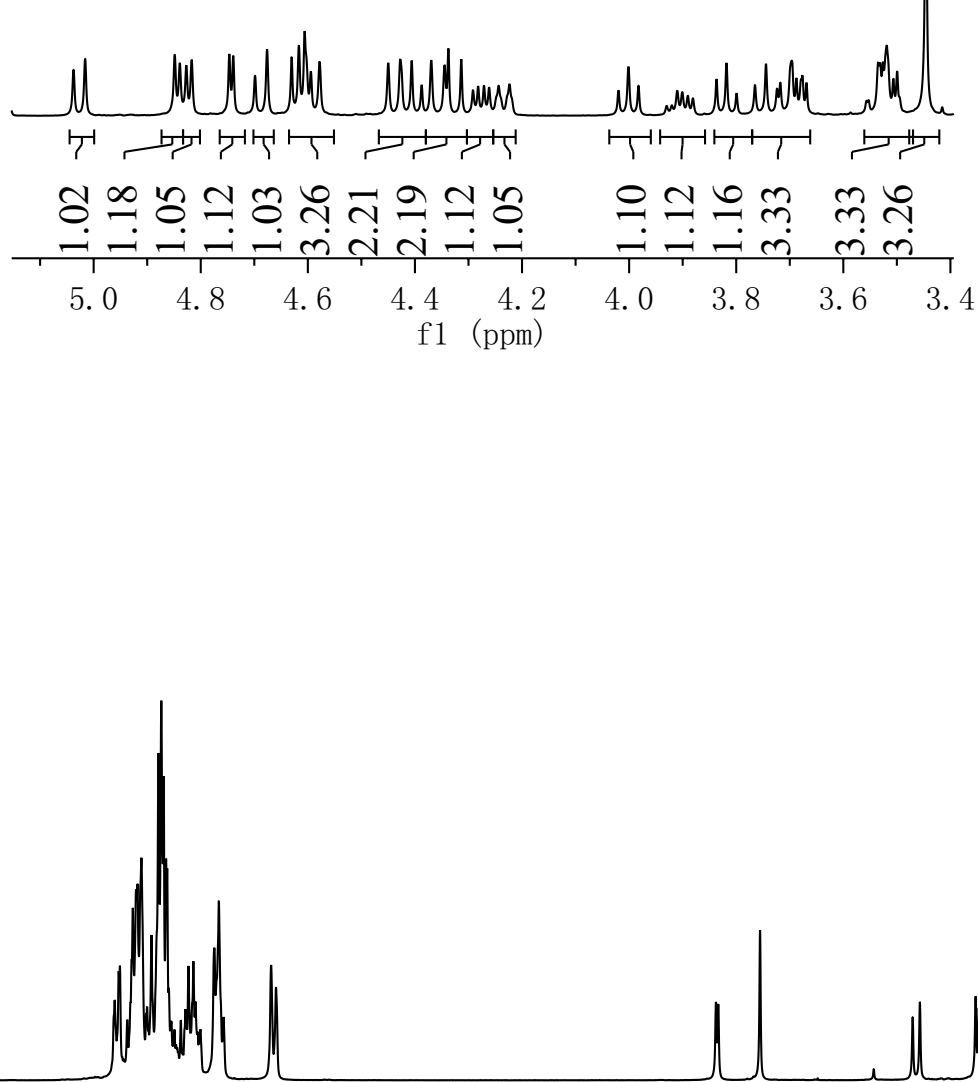

(1.0

6. 0
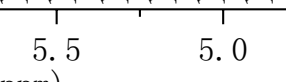

4.5

4. 0

3.5

3. 0

2.5

2. 0

1. 5 


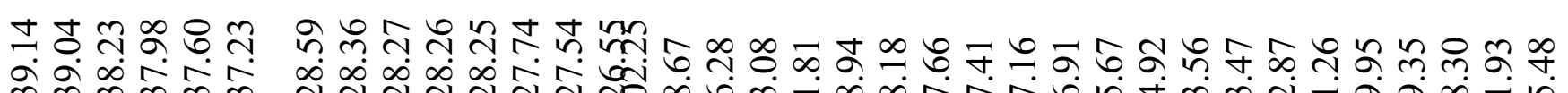

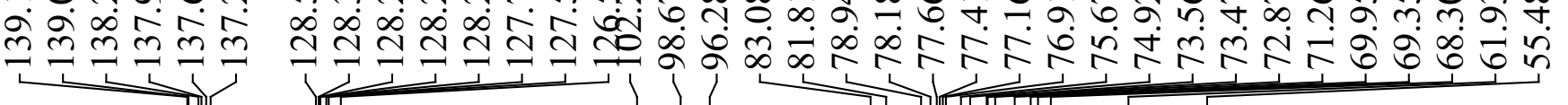

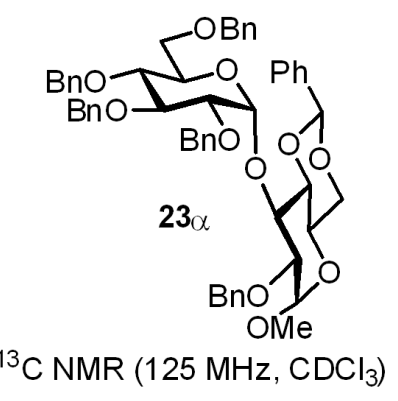

${ }^{13} \mathrm{C}$ NMR (125 MHz, $\left.\mathrm{CDCl}_{3}\right)$

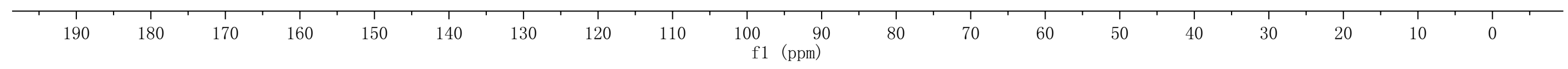




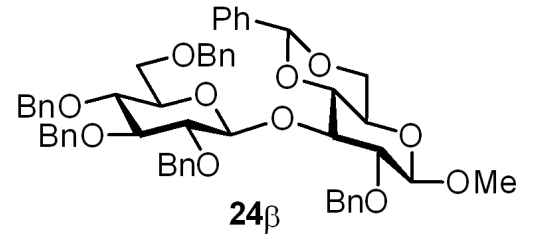

${ }^{1} \mathrm{H} \mathrm{NMR}\left(500 \mathrm{MHz}, \mathrm{CDCl}_{3}\right)$
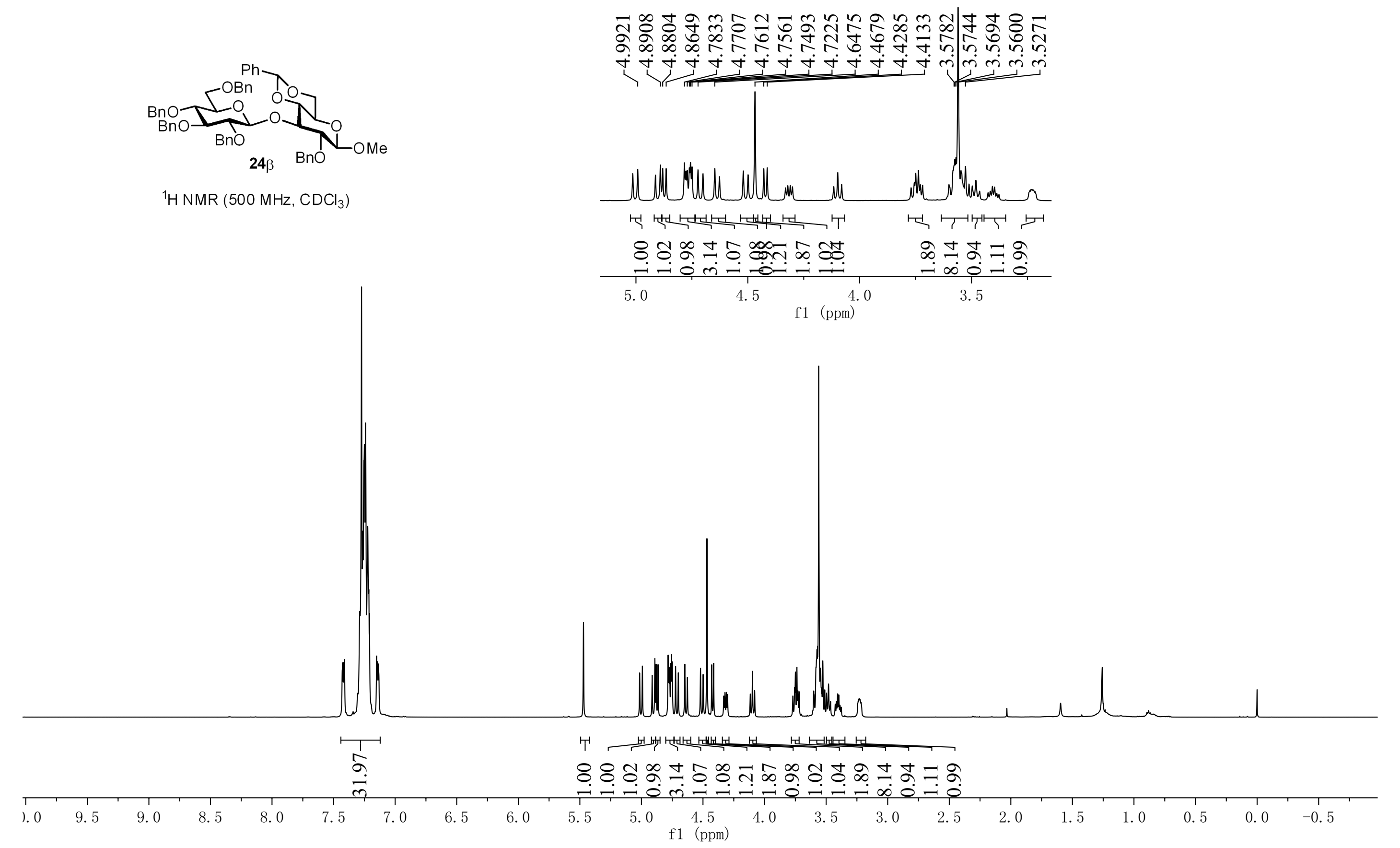


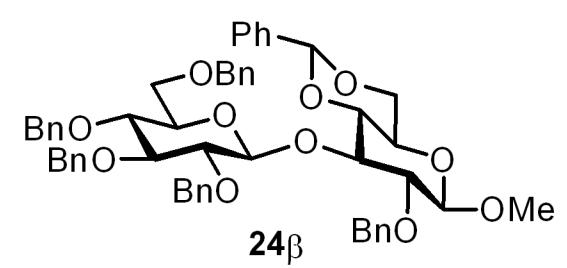

${ }^{13} \mathrm{C}$ NMR $\left(125 \mathrm{MHz}, \mathrm{CDCl}_{3}\right)$

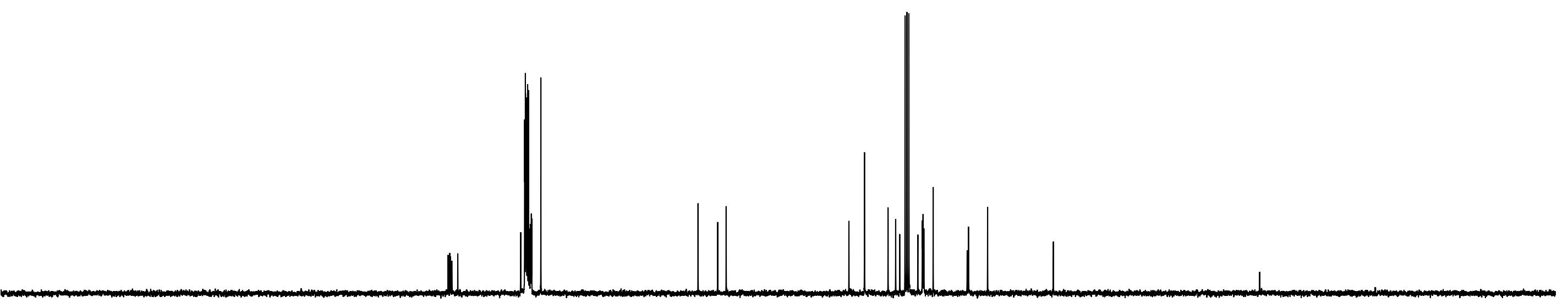

\begin{tabular}{|c|c|c|c|c|c|c|c|c|c|c|c|c|c|c|c|c|c|c|}
\hline $\begin{array}{l}1 \\
190\end{array}$ & 180 & 1 & 160 & 150 & 14 & $\begin{array}{c}1 \\
130\end{array}$ & 12 & 110 & \multicolumn{2}{|c|}{1,1} & 80 & & 19 & & 1 & & 20 & \\
\hline
\end{tabular}




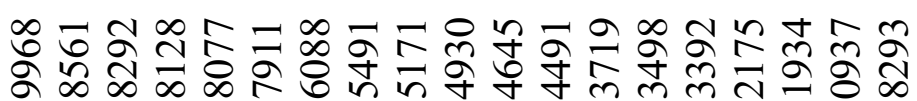

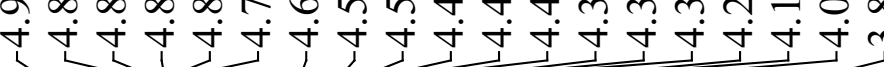
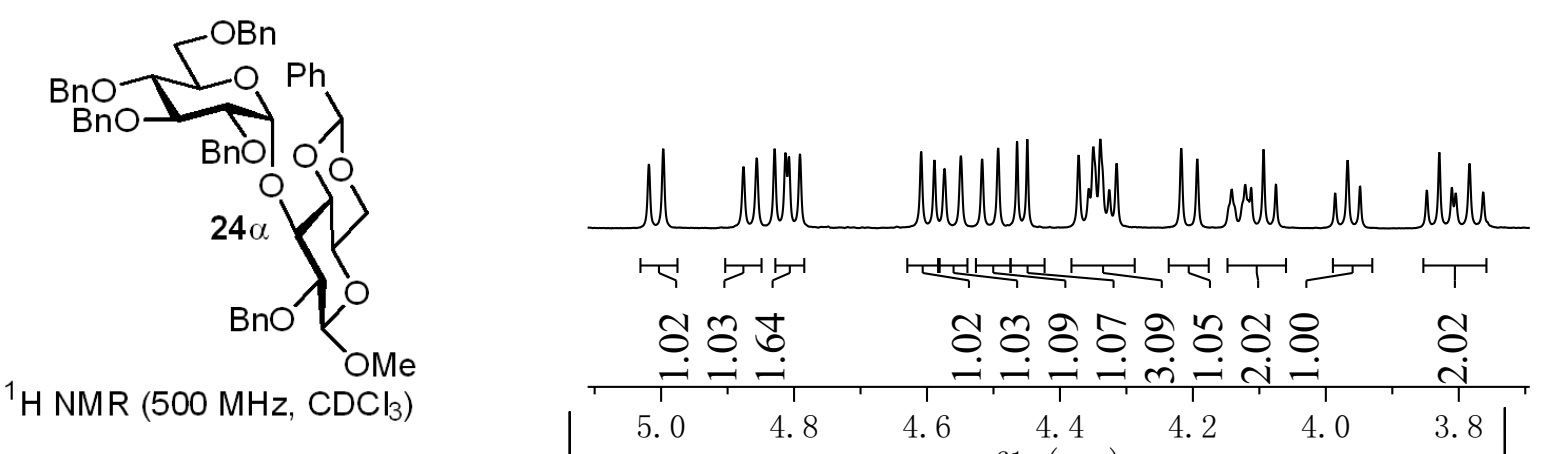

${ }^{1} \mathrm{H}$ NMR $\left(500 \mathrm{MHz}, \mathrm{CDCl}_{3}\right)$

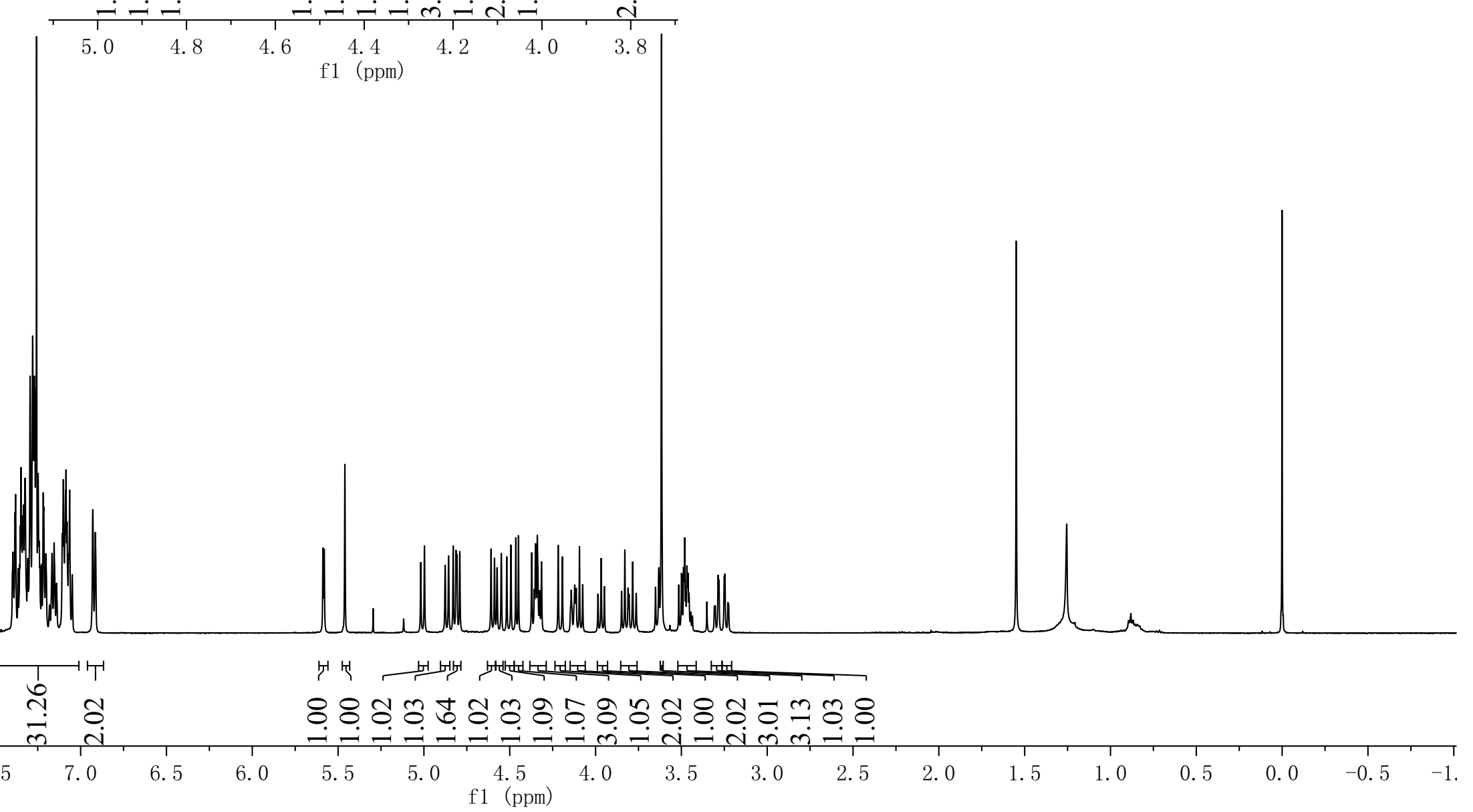




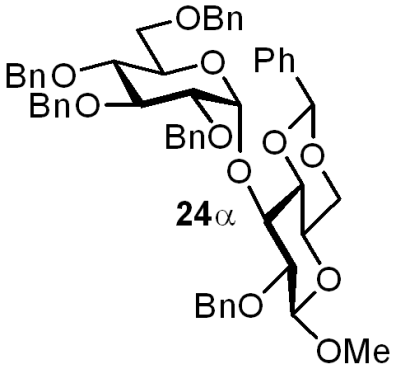

${ }^{13} \mathrm{C}$ NMR $\left(125 \mathrm{MHz}, \mathrm{CDCl}_{3}\right)$ 

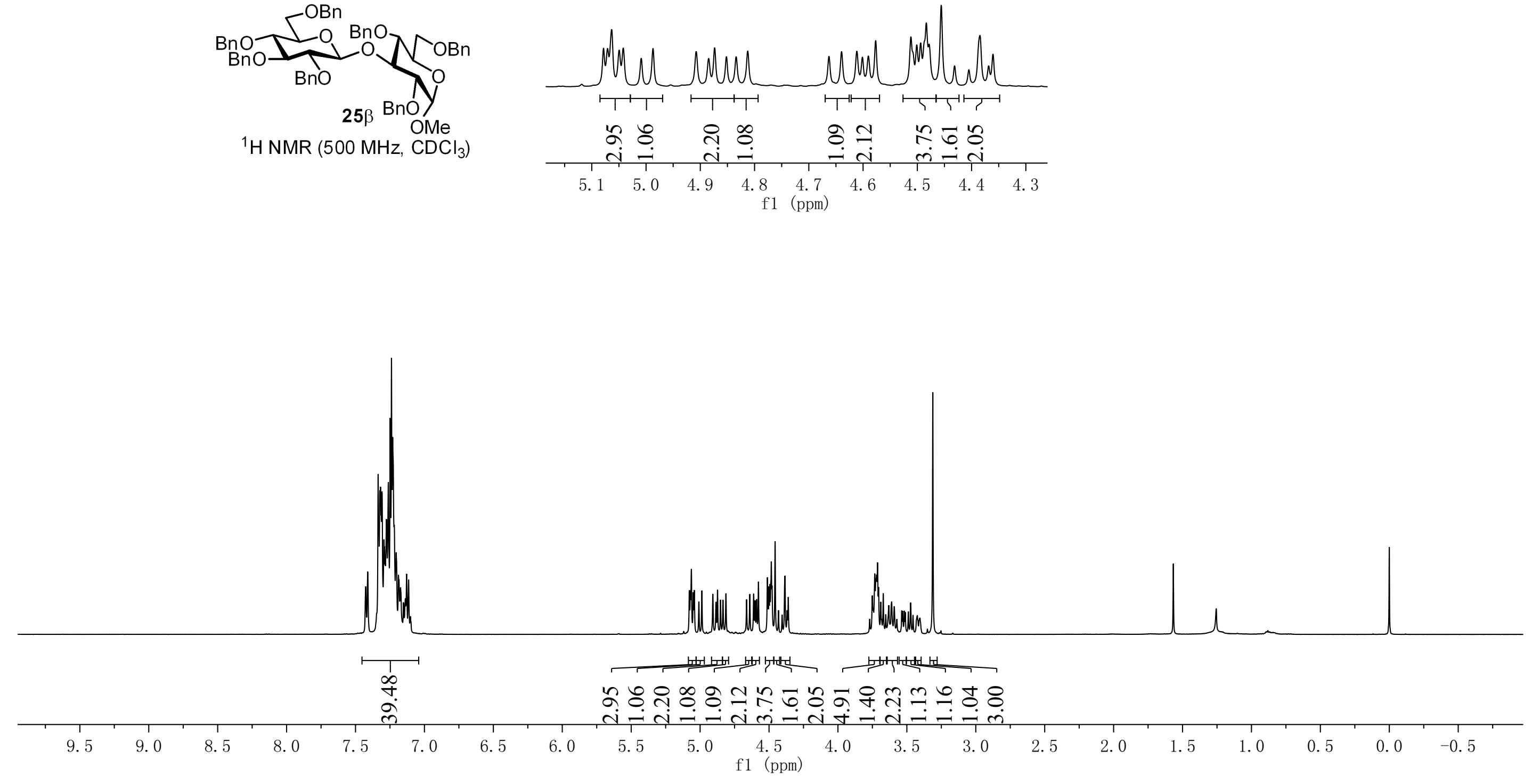


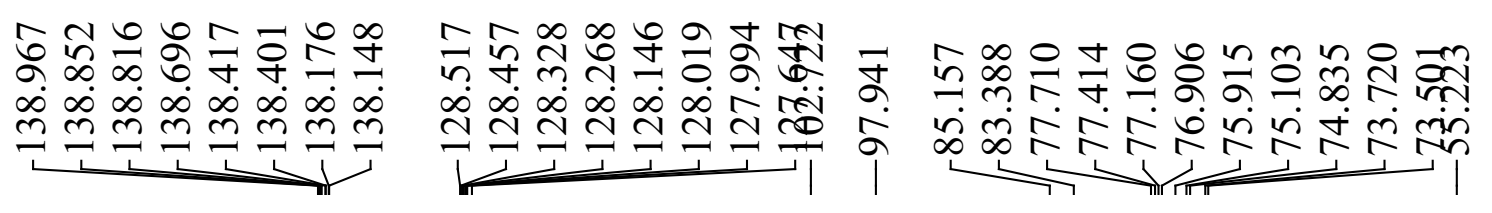

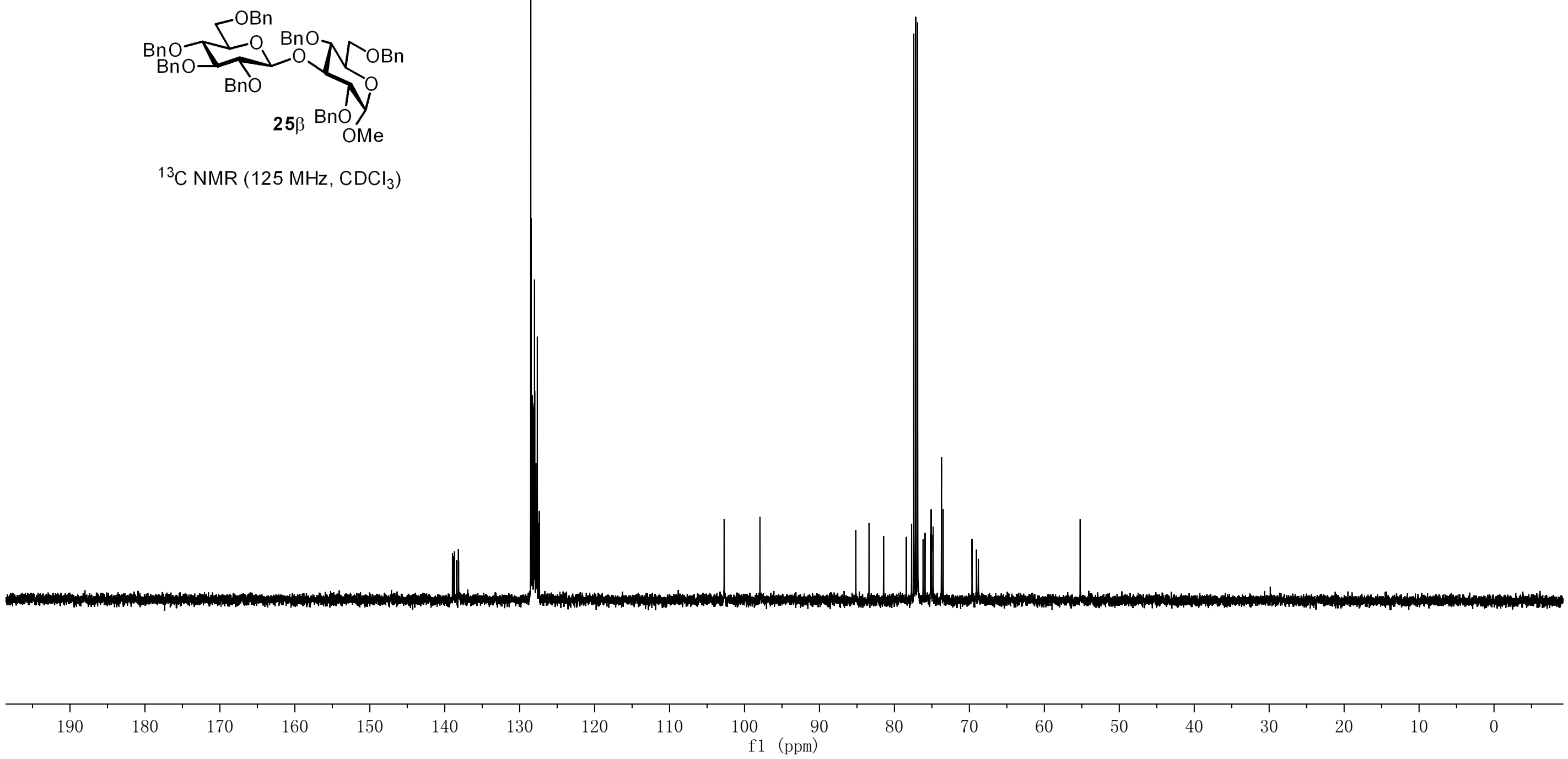



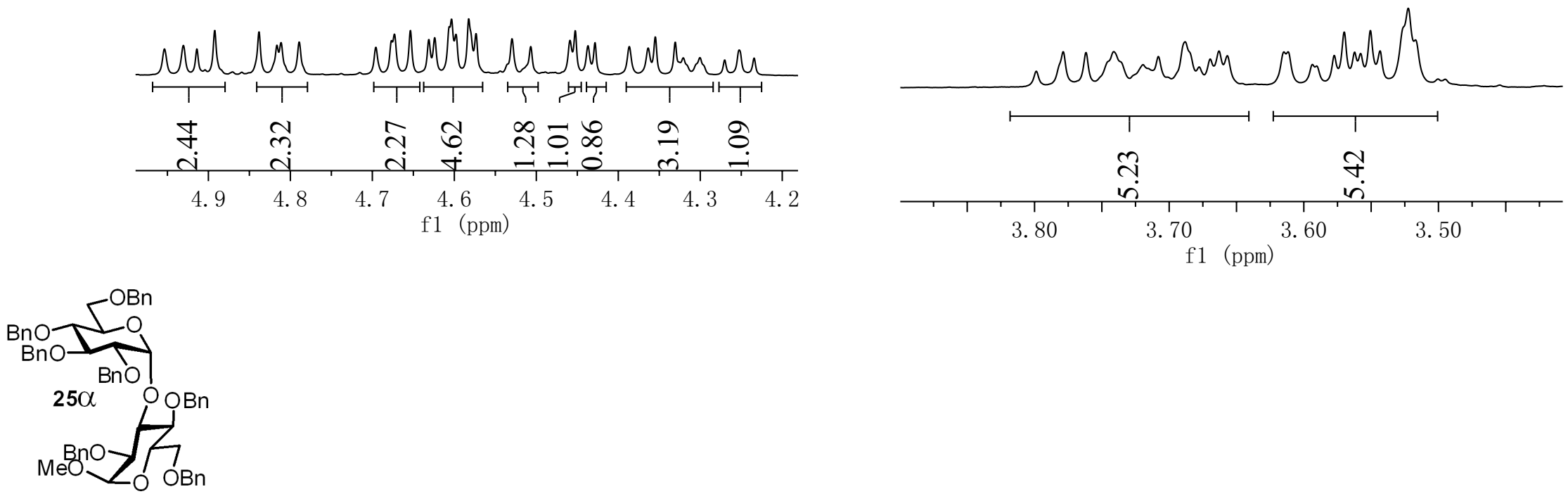

${ }^{1} \mathrm{H} \mathrm{NMR} \mathrm{(500} \mathrm{MHz,} \mathrm{CDCl}_{3}$ )

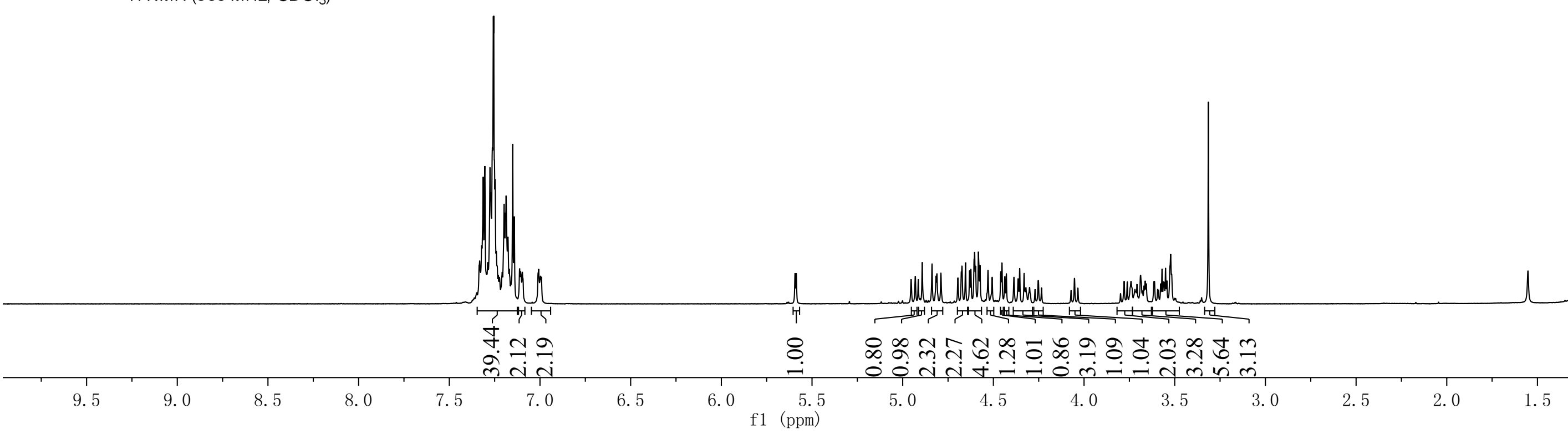




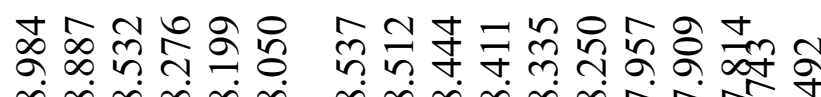

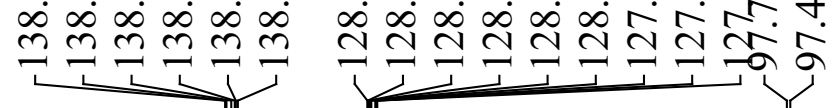

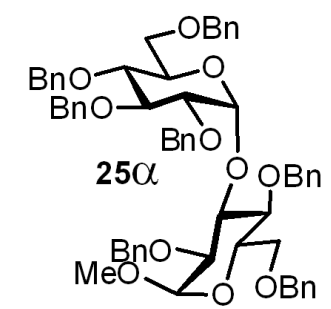

${ }^{13} \mathrm{CNMR}\left(125 \mathrm{MHz}, \mathrm{CDCl}_{3}\right)$

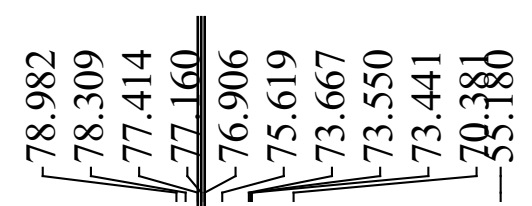

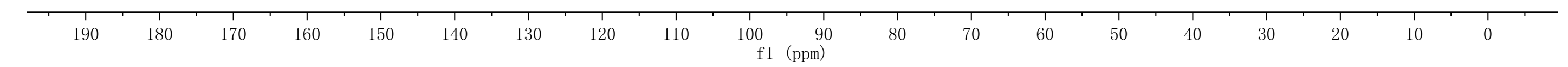




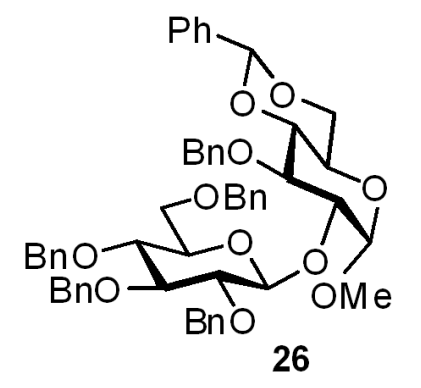

${ }^{1} \mathrm{H}$ NMR $\left(500 \mathrm{MHz}, \mathrm{CDCl}_{3}\right)$
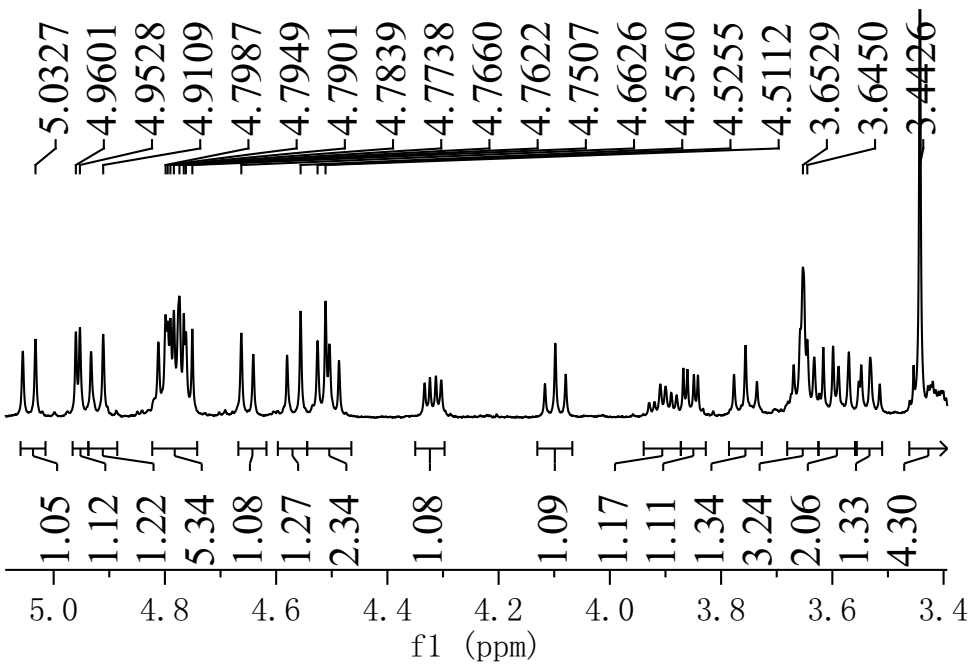

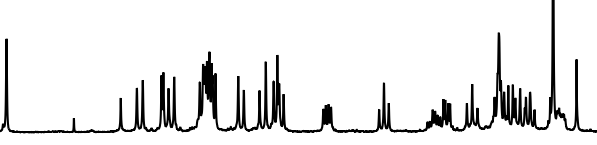

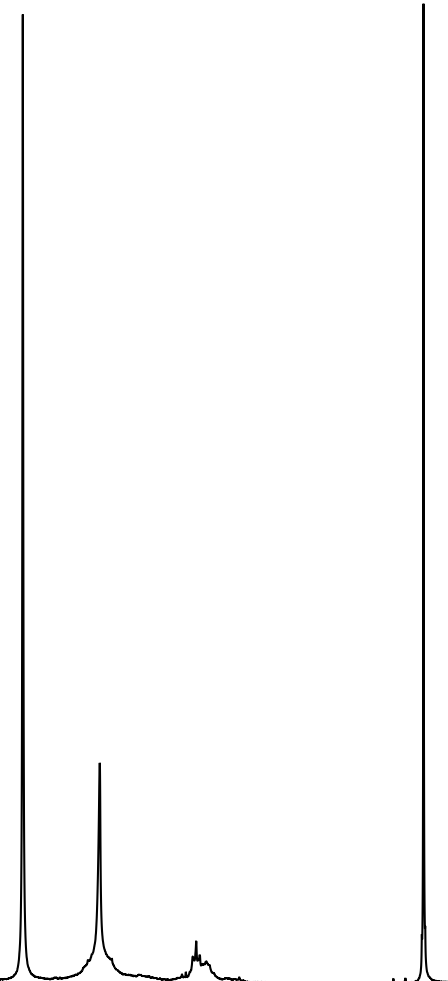

유

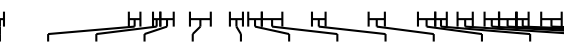

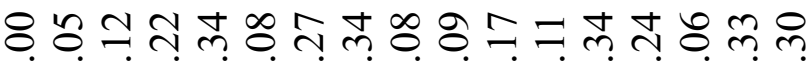

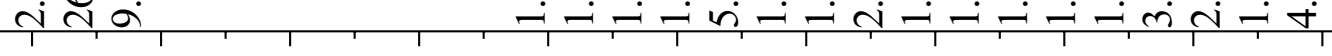




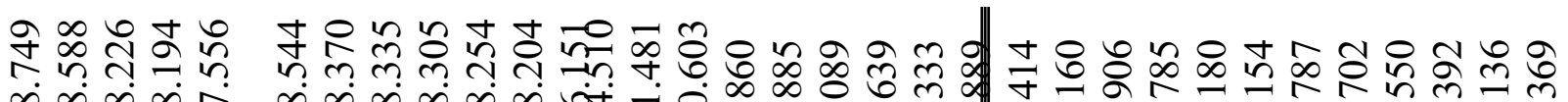

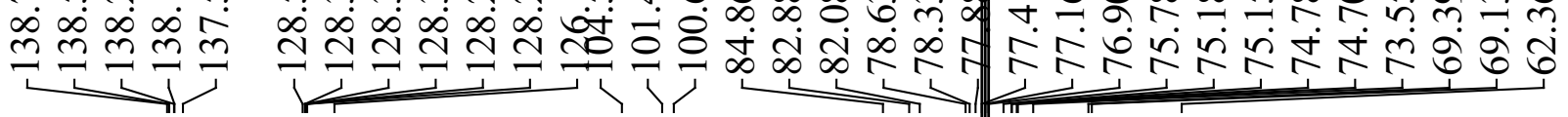

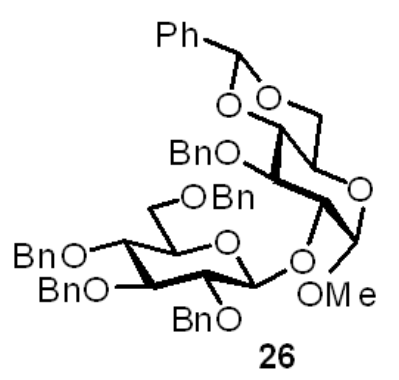

${ }^{13} \mathrm{C} \mathrm{NMR}\left(125 \mathrm{MHz}, \mathrm{CDCl}_{3}\right)$

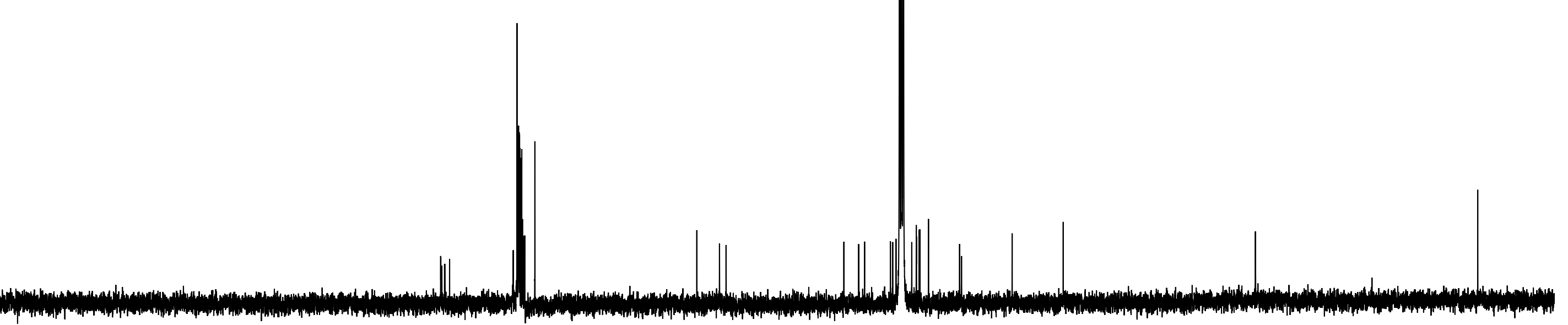

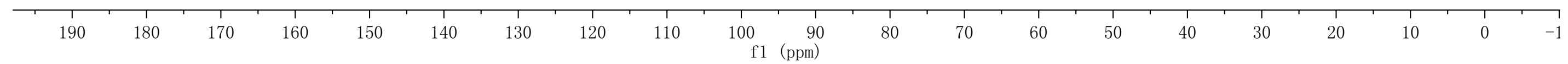



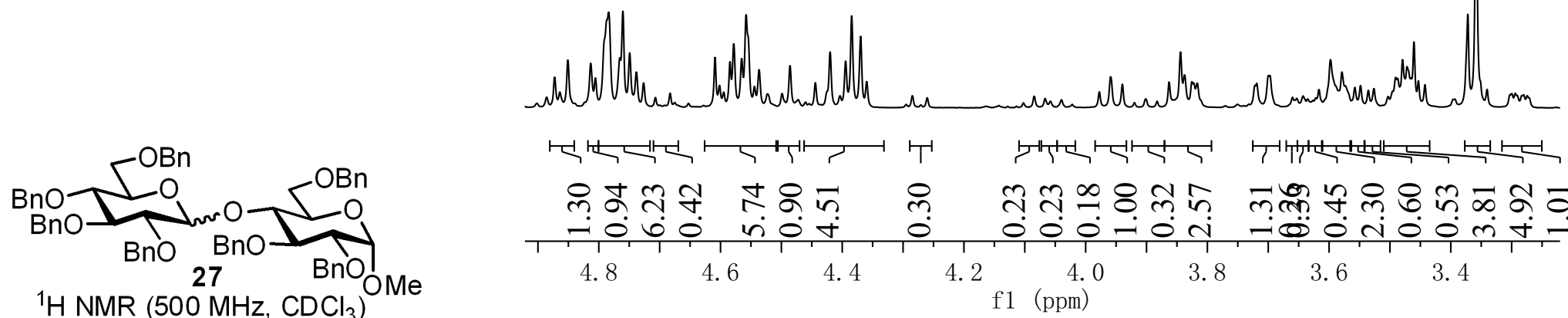

(

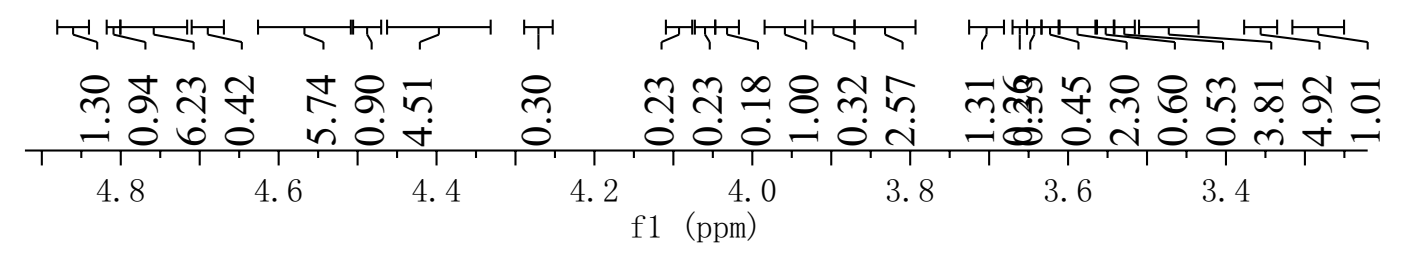

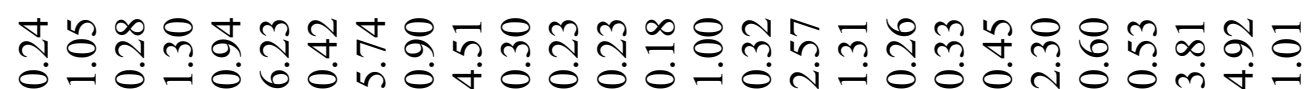

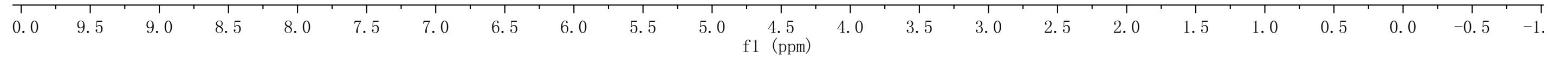




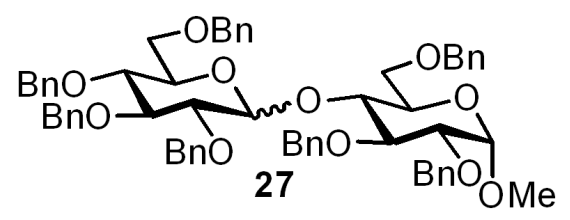

${ }^{13} \mathrm{C} \mathrm{NMR}\left(125 \mathrm{MHz}, \mathrm{CDCl}_{3}\right)$ 


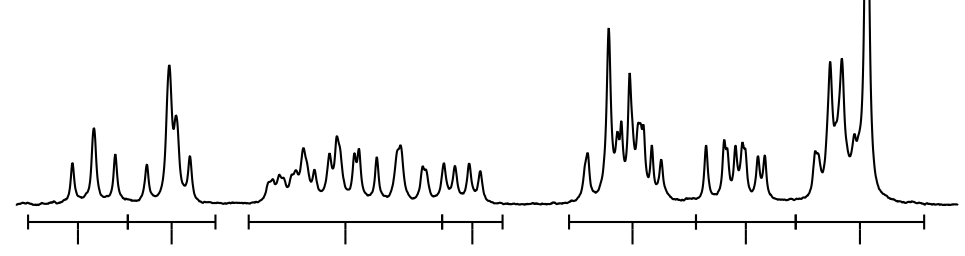

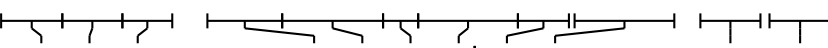

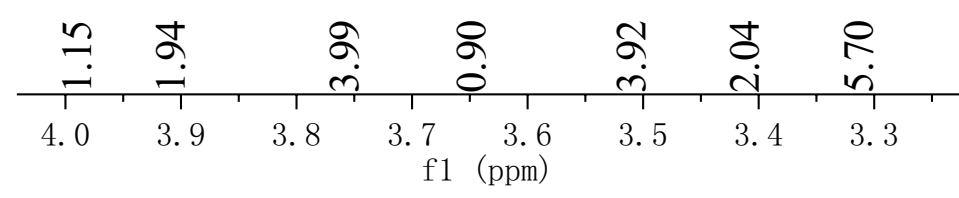

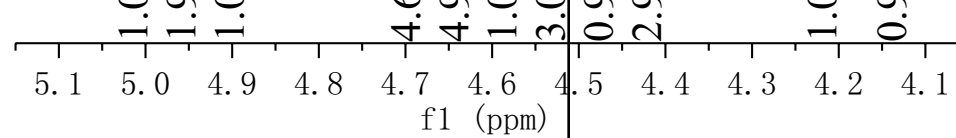

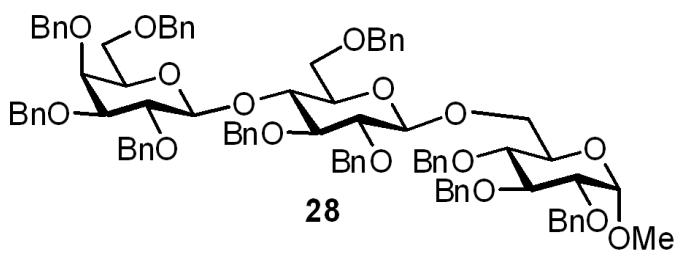

${ }^{1} \mathrm{H} \mathrm{NMR}\left(500 \mathrm{MHz}, \mathrm{CDCl}_{3}\right)$ 


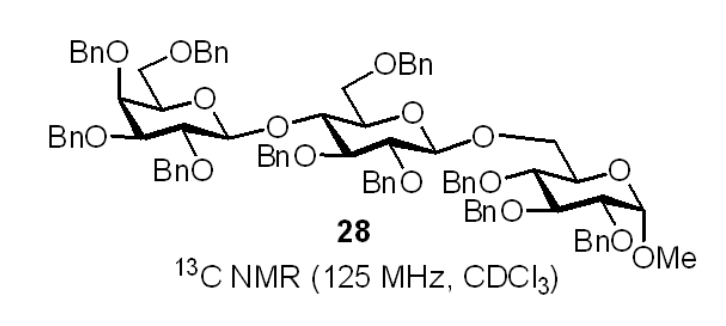

(1)

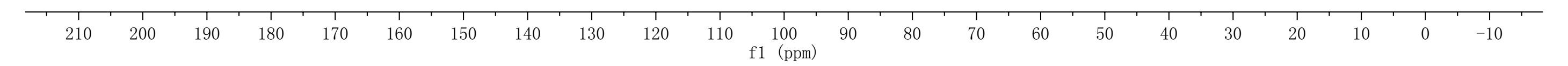



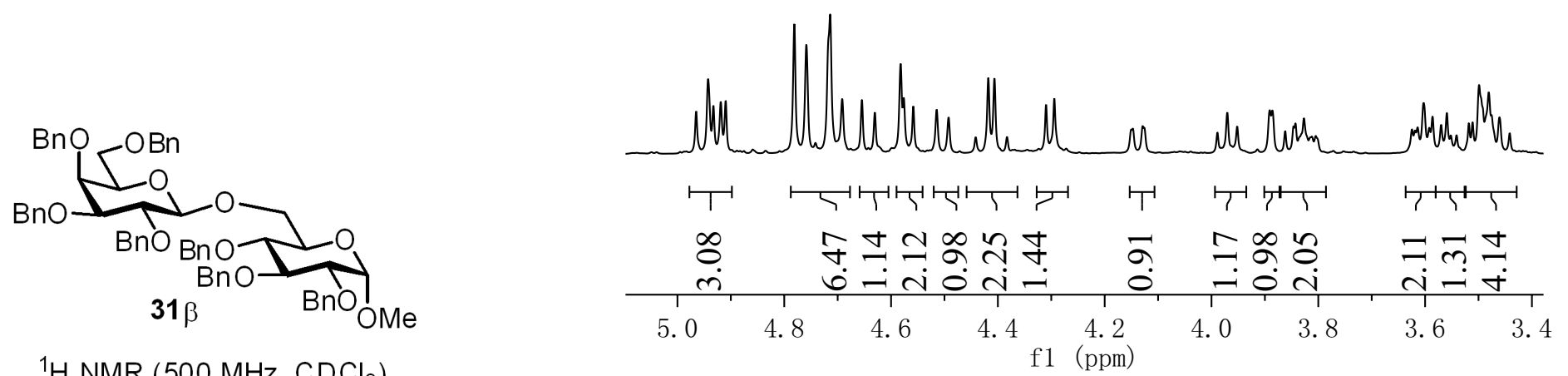

${ }^{1} \mathrm{H} \mathrm{NMR}\left(500 \mathrm{MHz}, \mathrm{CDCl}_{3}\right)$

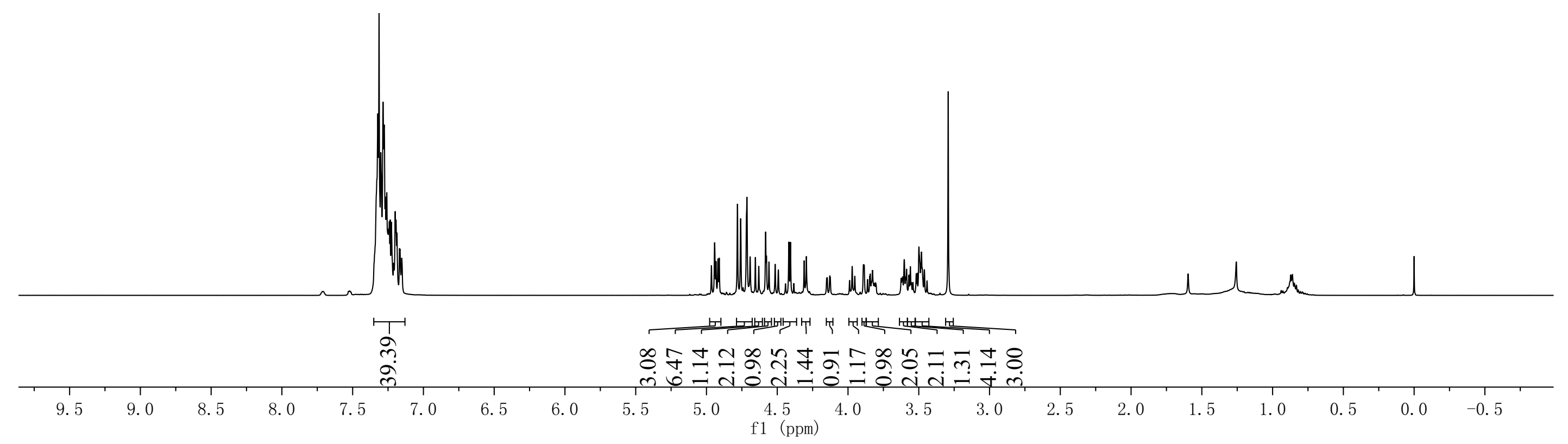


웅

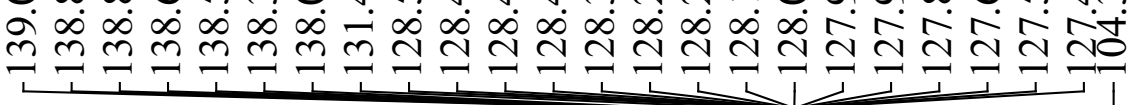
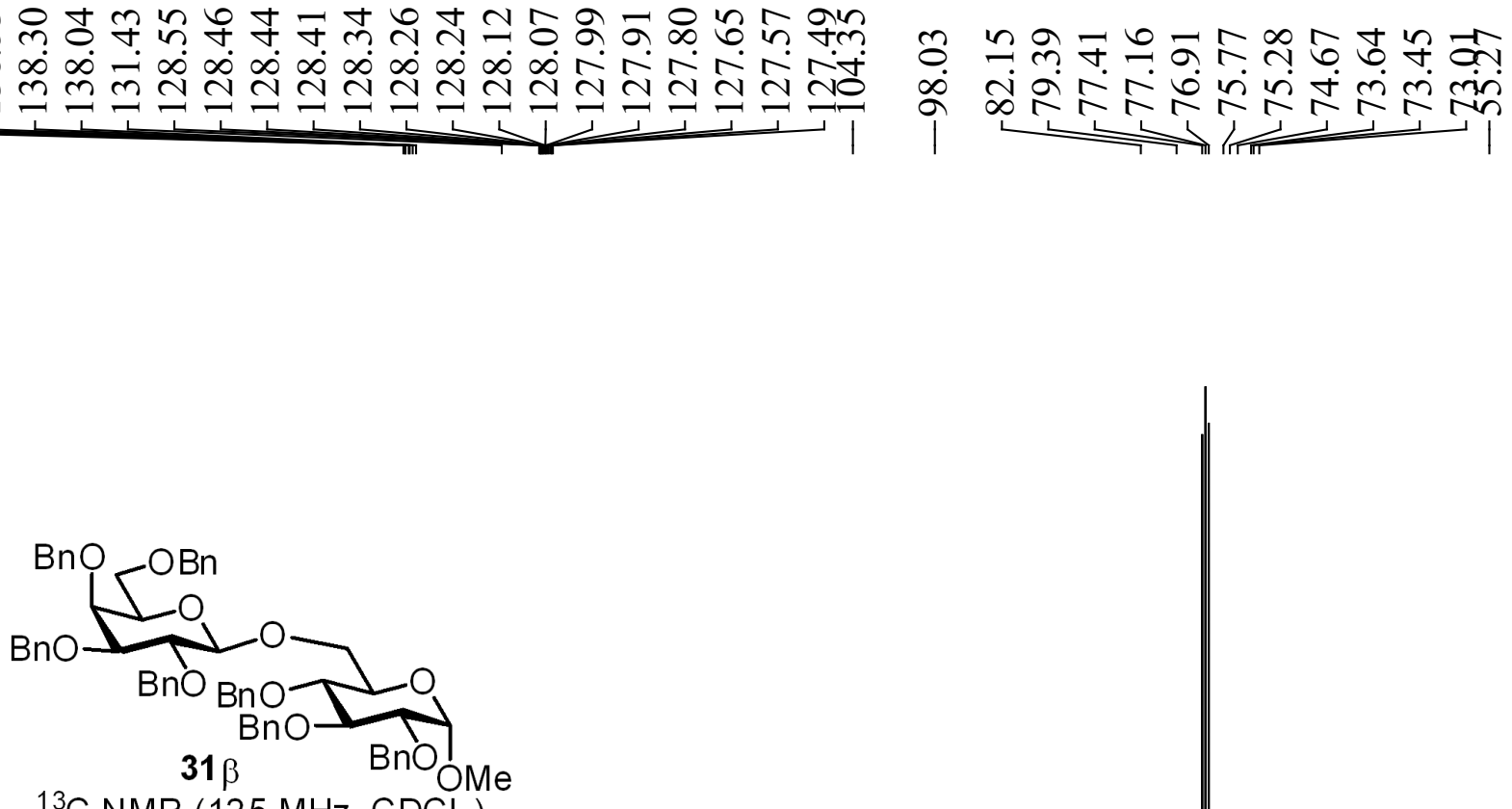

${ }^{13} \mathrm{C}$ NMR $\left(125 \mathrm{MHz}, \mathrm{CDCl}_{3}\right)$

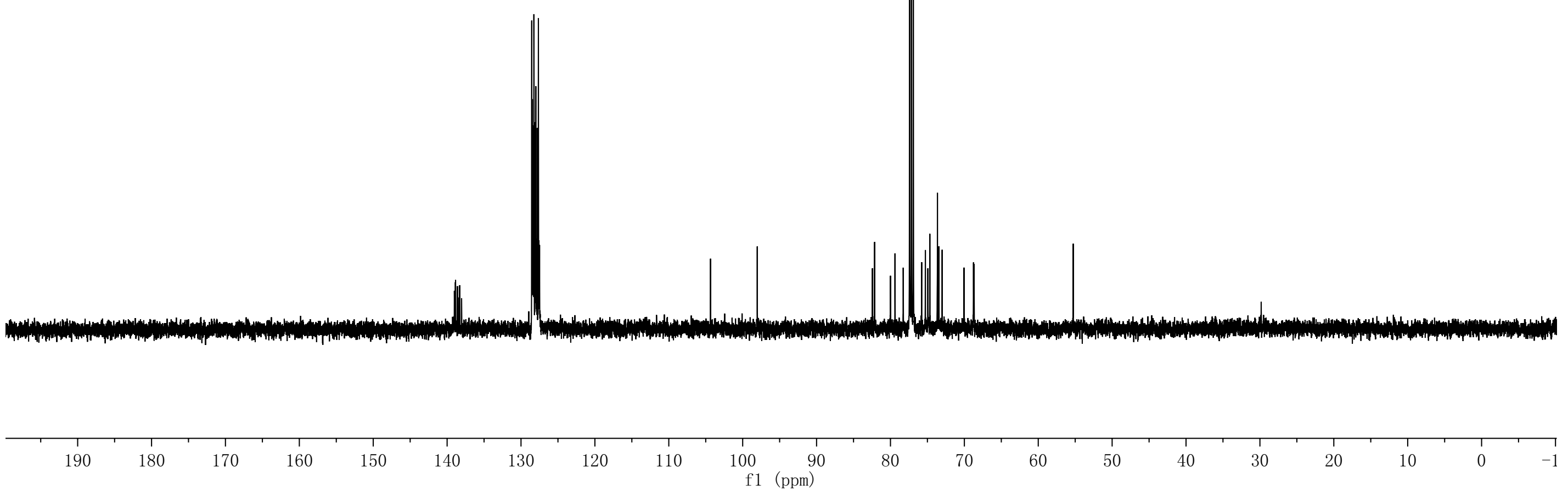




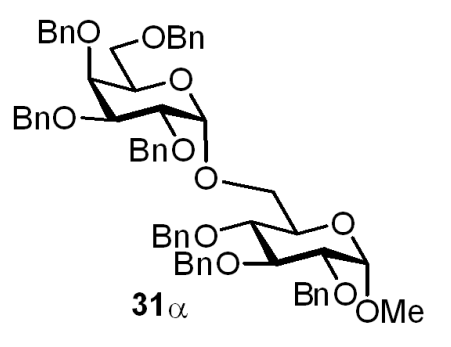

${ }^{1} \mathrm{H}$ NMR $\left(500 \mathrm{MHz}, \mathrm{CDCl}_{3}\right)$

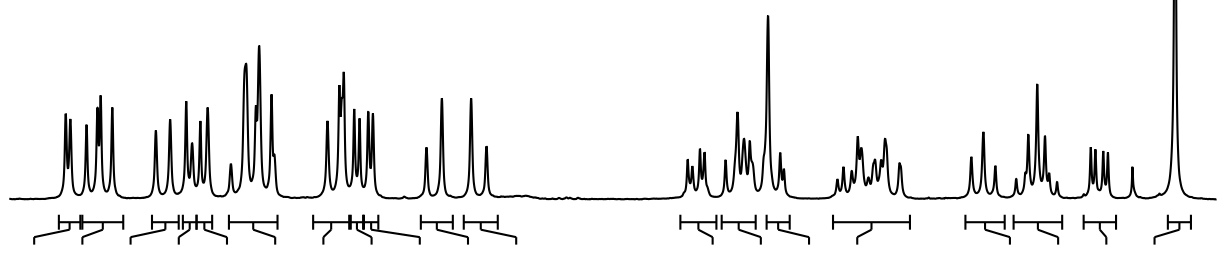

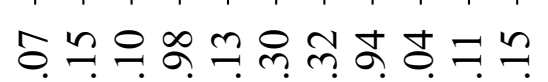
$=\infty 88$

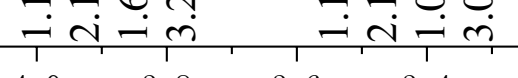

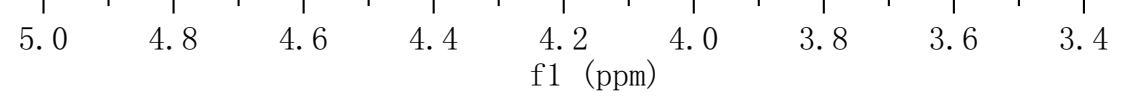
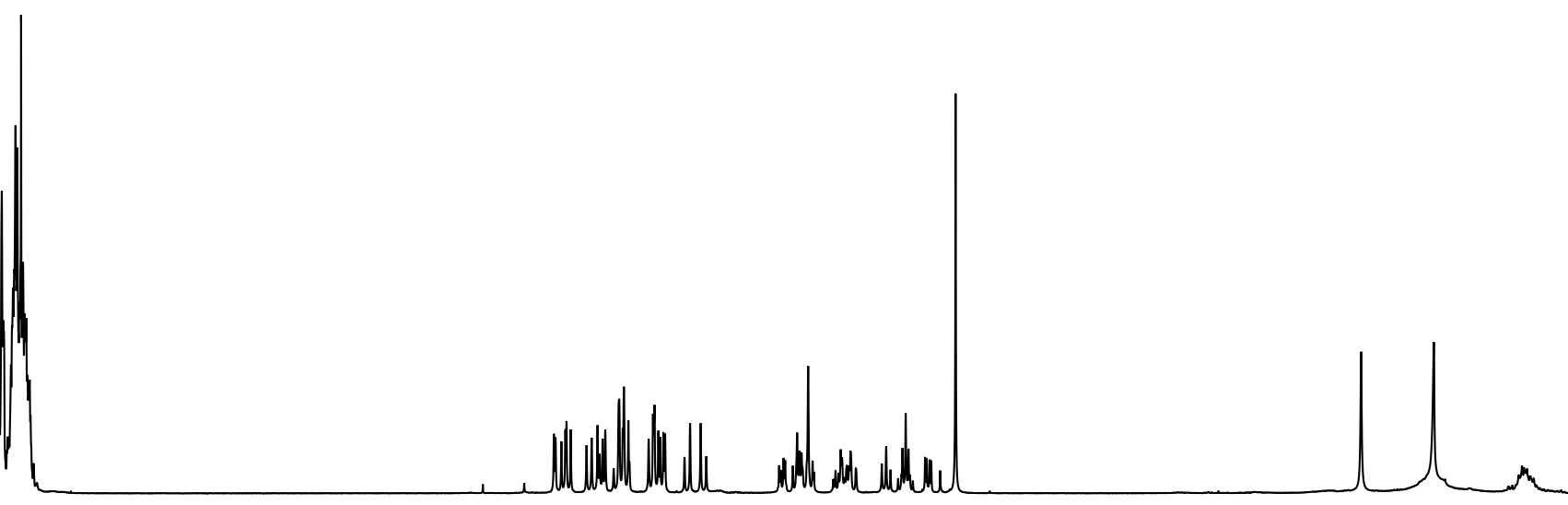

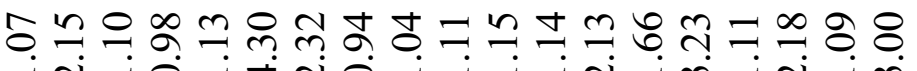

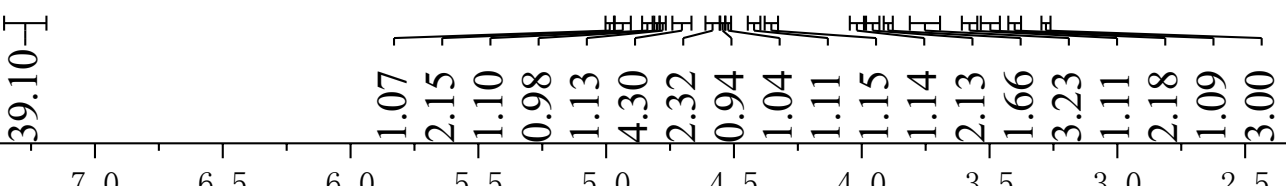

$\begin{array}{llllll}0.0 & 9.5 & 9.0 & 8.5 & 8.0 & 7.5\end{array}$

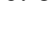

$6.0 \quad 5.5$

5.0

f1 (ppm)

2.52 .0

1.5

1.0

0.5

0.0

$-0.5$ 


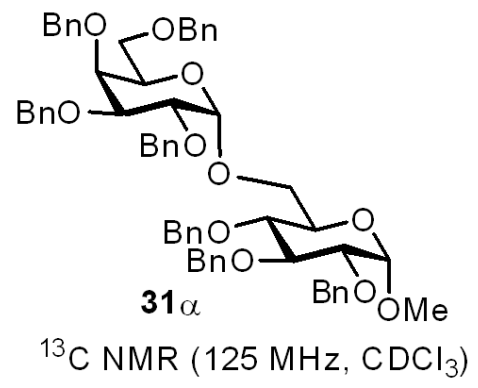




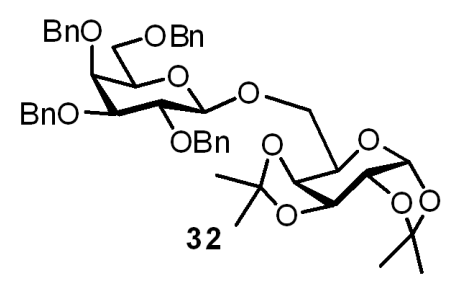

${ }^{1} \mathrm{HNMR}\left(500 \mathrm{MHz}, \mathrm{CDCl}_{3}\right)$

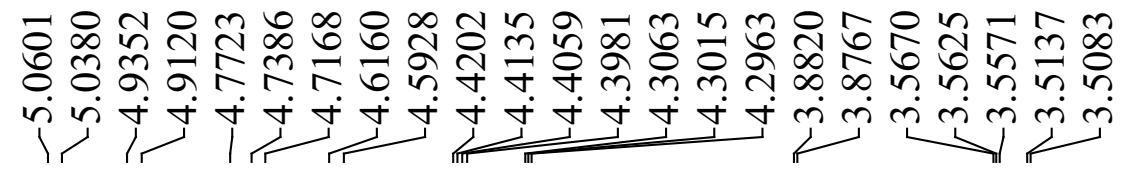

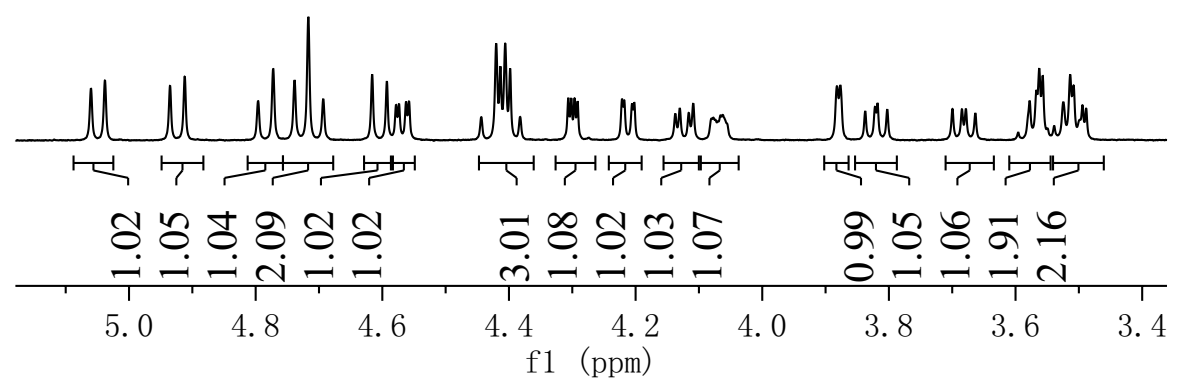

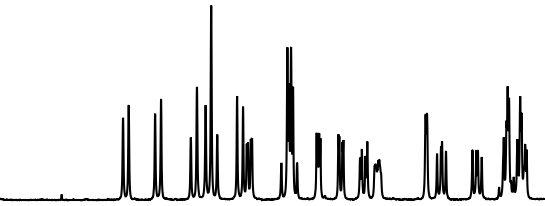

个'

ช ชิ

-

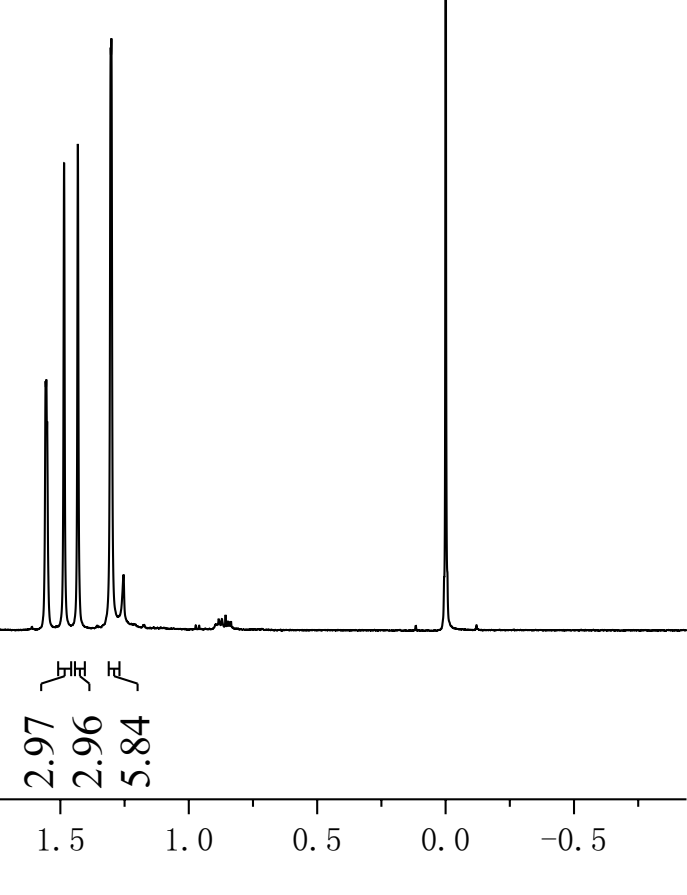




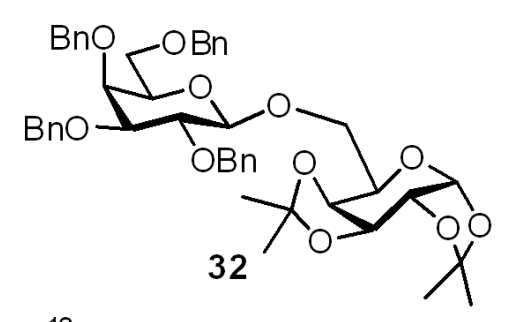

${ }^{13} \mathrm{C} \mathrm{NMR}\left(125 \mathrm{MHz}, \mathrm{CDCl}_{3}\right)$

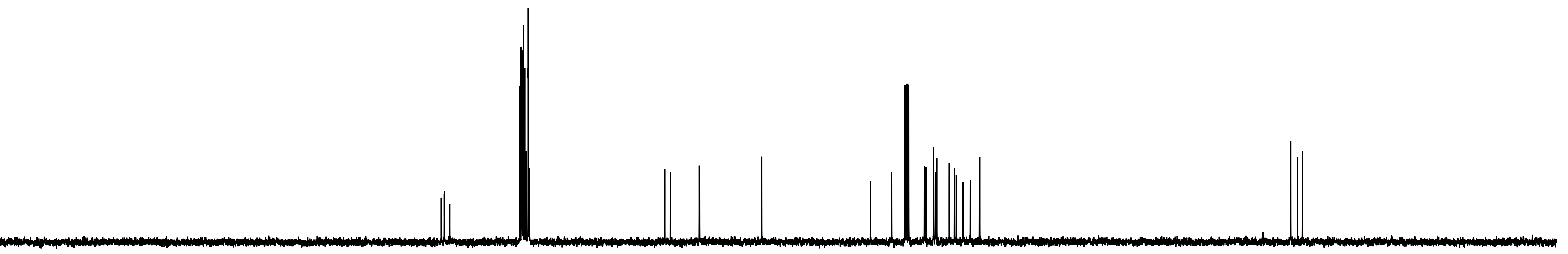

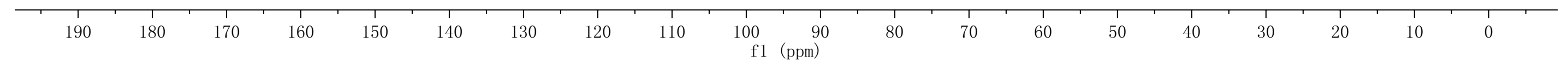




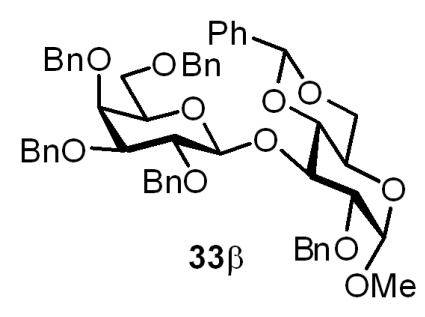

${ }^{1} \mathrm{H} \mathrm{NMR}\left(500 \mathrm{MHz}, \mathrm{CDCl}_{3}\right)$
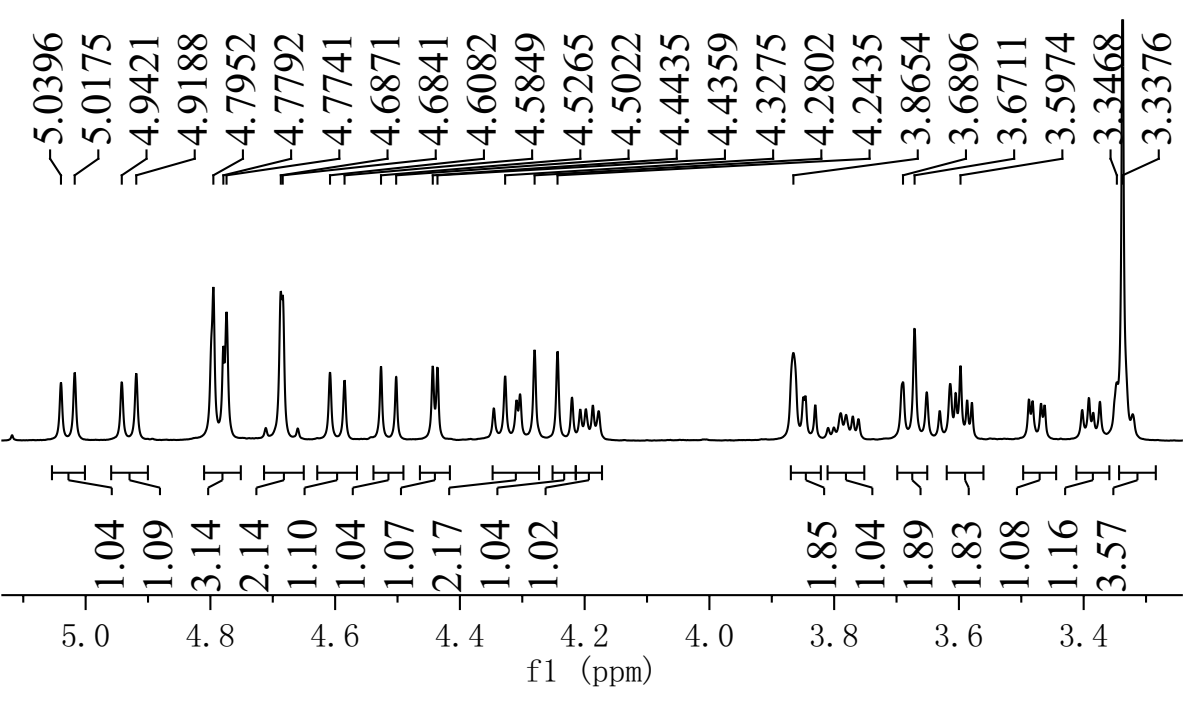

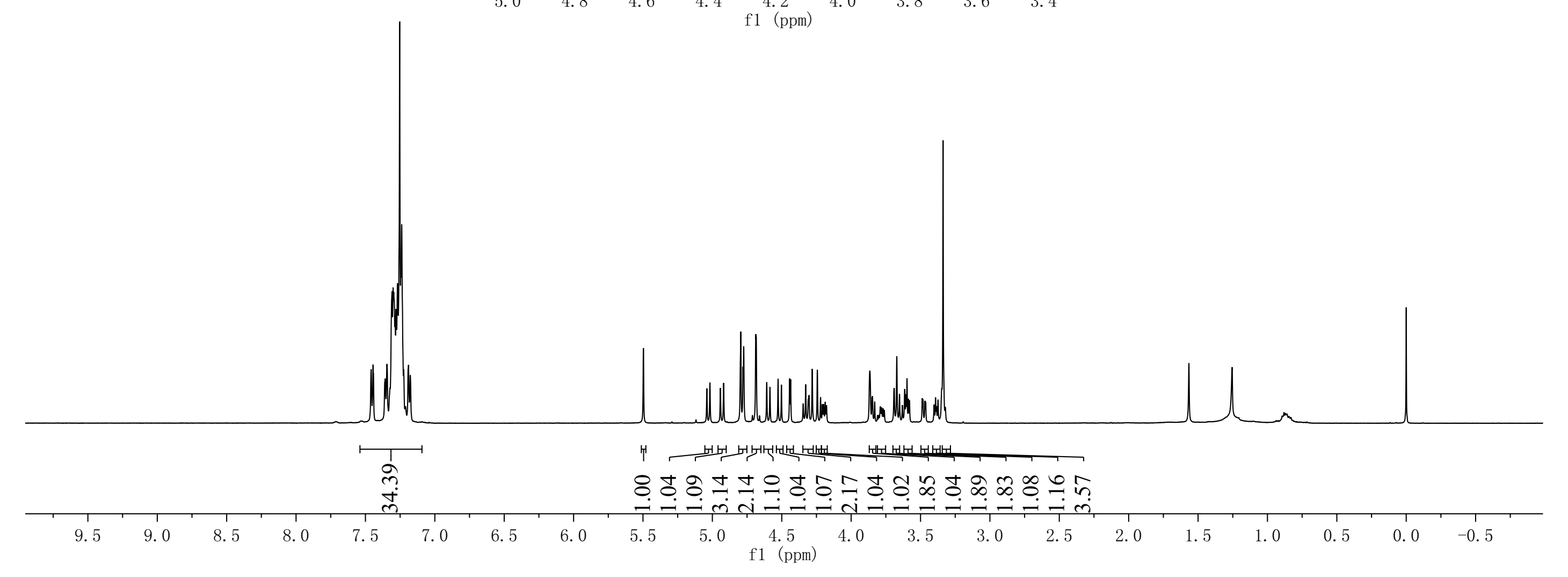




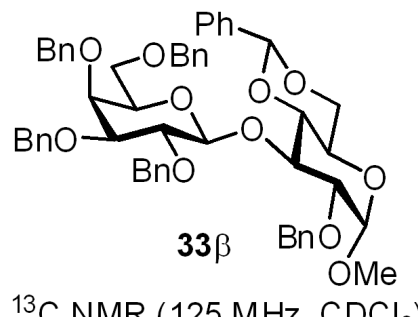

${ }^{13} \mathrm{C} \mathrm{NMR}\left(125 \mathrm{MHz}, \mathrm{CDCl}_{3}\right)$ 


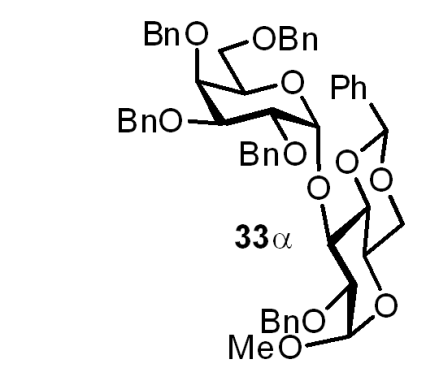

${ }^{1} \mathrm{HNMR}\left(500 \mathrm{MHz}, \mathrm{CDCl}_{3}\right)$

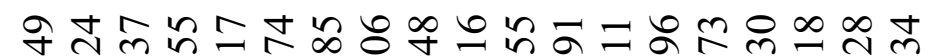
के क્木

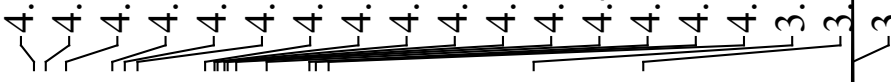

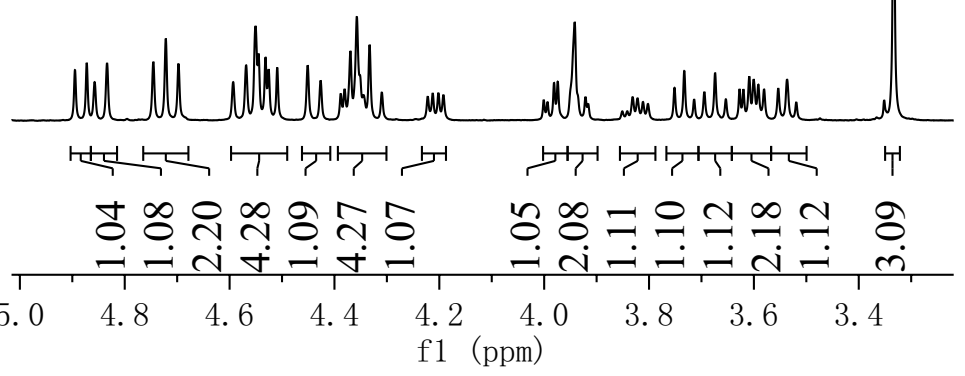

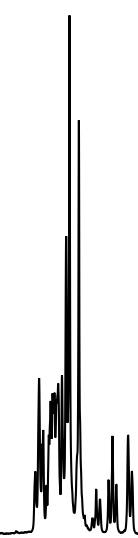

(1)

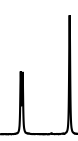

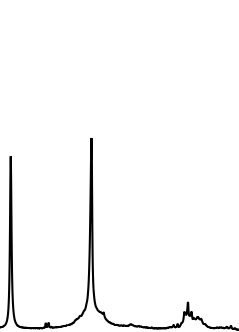

H

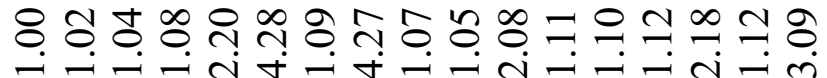

$\dot{m}$ 


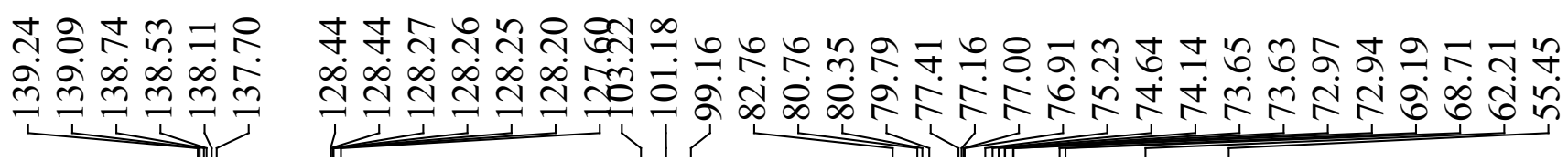
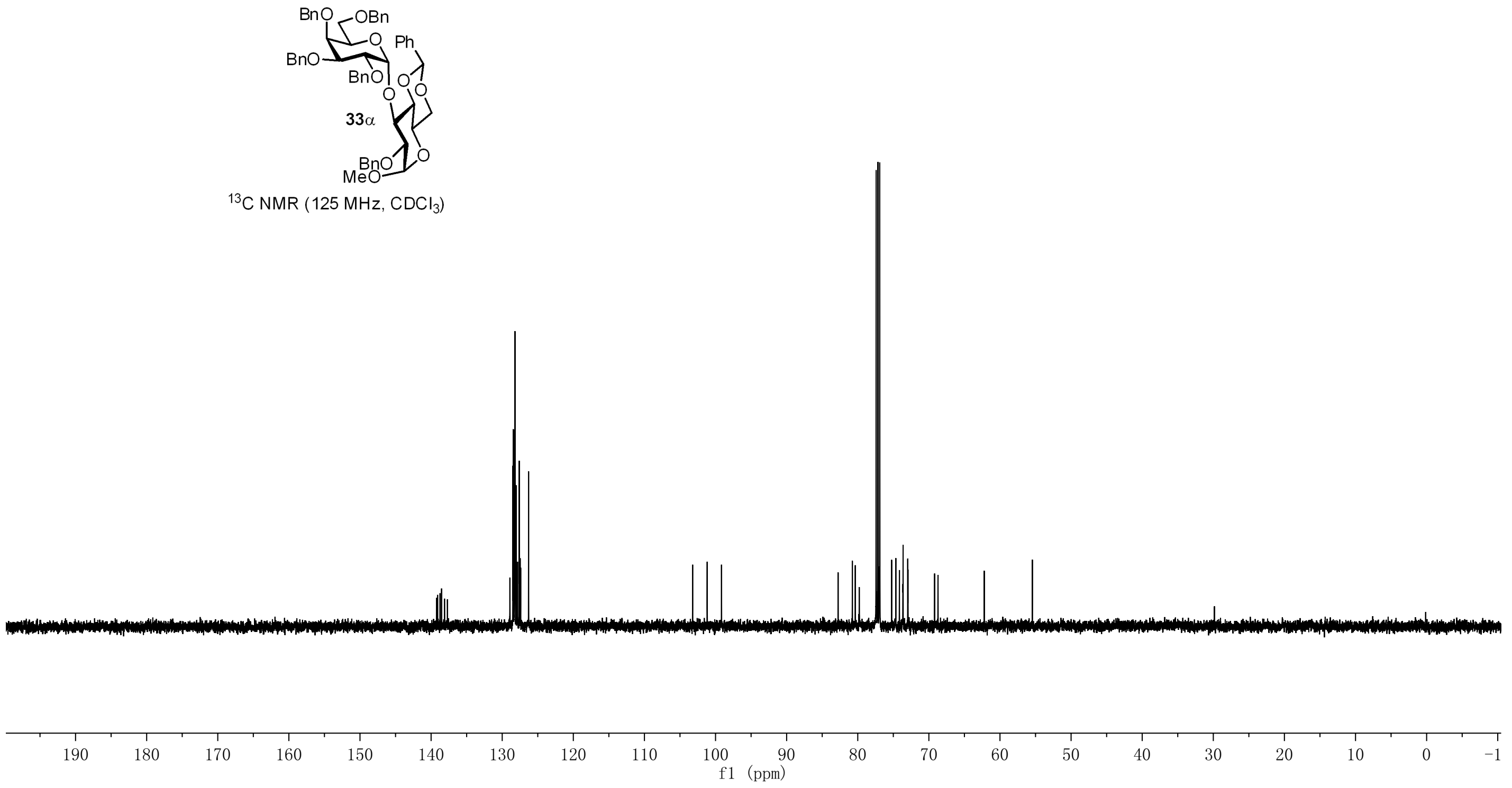


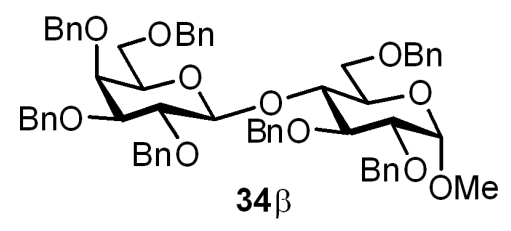

${ }^{1} \mathrm{H}$ NMR $\left(500 \mathrm{MHz}, \mathrm{CDCl}_{3}\right)$

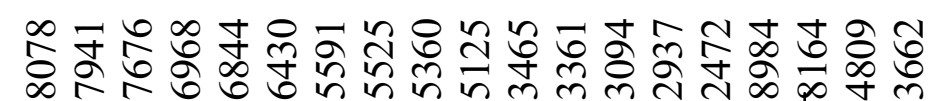

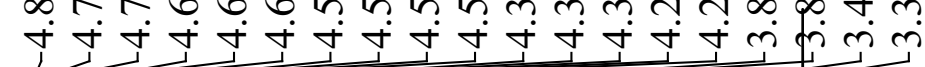

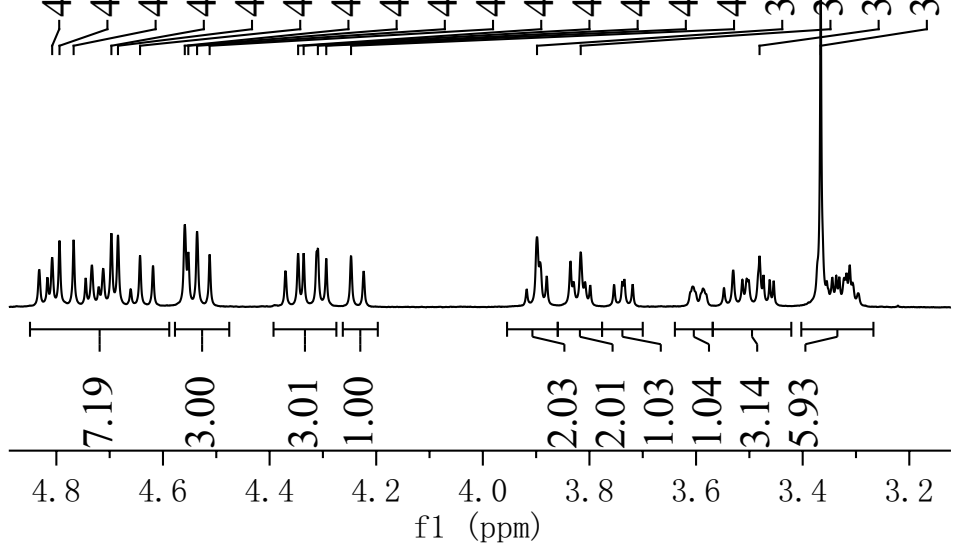

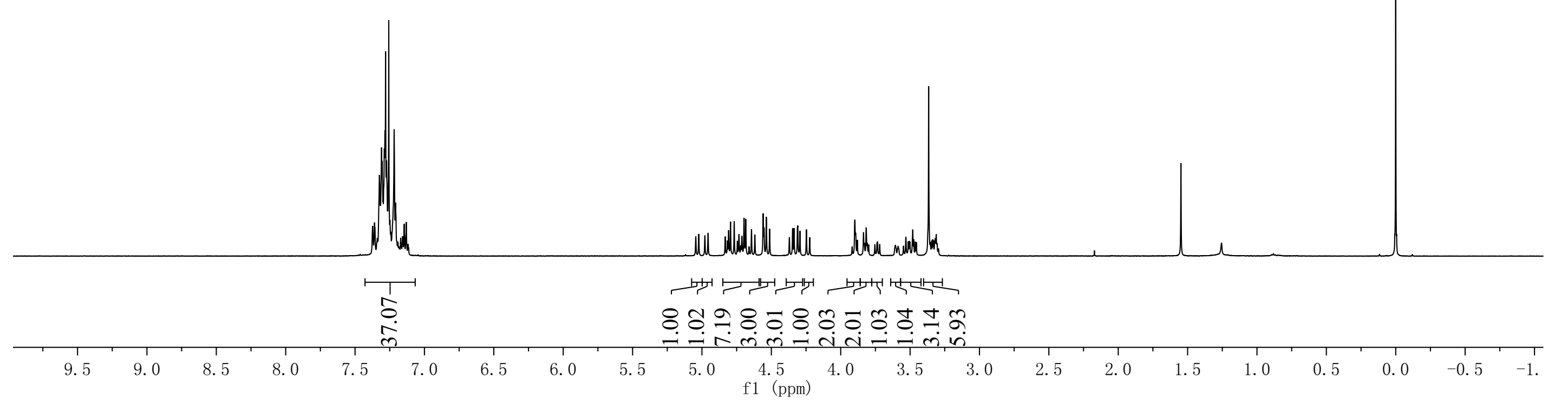




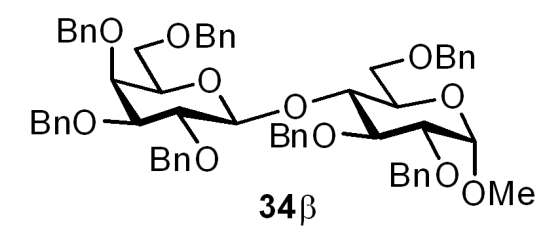

${ }^{13} \mathrm{C}$ NMR $\left(125 \mathrm{MHz}, \mathrm{CDCl}_{3}\right)$

\begin{tabular}{|c|c|c|c|c|c|c|}
\hline 1 & $T$ & $T$ & $T$ & $T$ & $T$ & \\
\hline 190 & 180 & 170 & 160 & 150 & 140 & 130 \\
\hline
\end{tabular}

110

$\begin{array}{cccc}10 & 100 & 90 & 80 \\ & \mathrm{f} 1 & (\mathrm{ppm})\end{array}$

(1)

$\begin{array}{llllllll}1 & 1 & 1 & 1 & 1 & 1 & 1 \\ 60 & 50 & 40 & 30 & 20 & 10 & 0 & -11\end{array}$




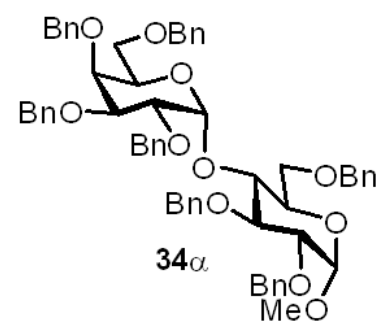

${ }^{1} \mathrm{H} \mathrm{NMR}\left(500 \mathrm{MHz}, \mathrm{CDCl}_{3}\right)$

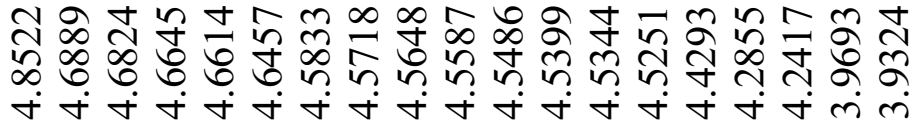

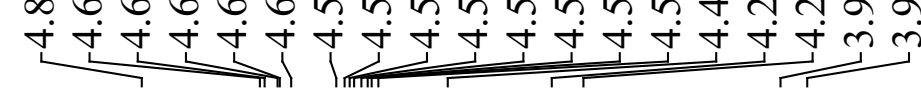

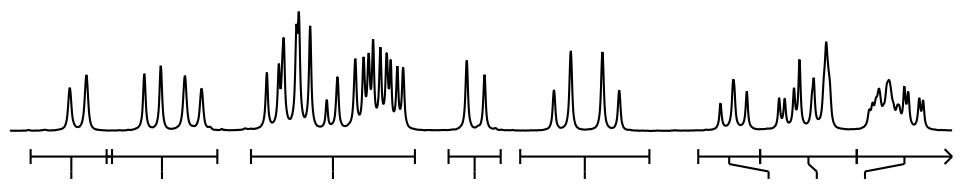

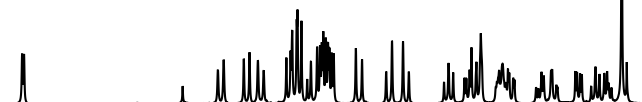

\section{๖ุ ๙ุ}
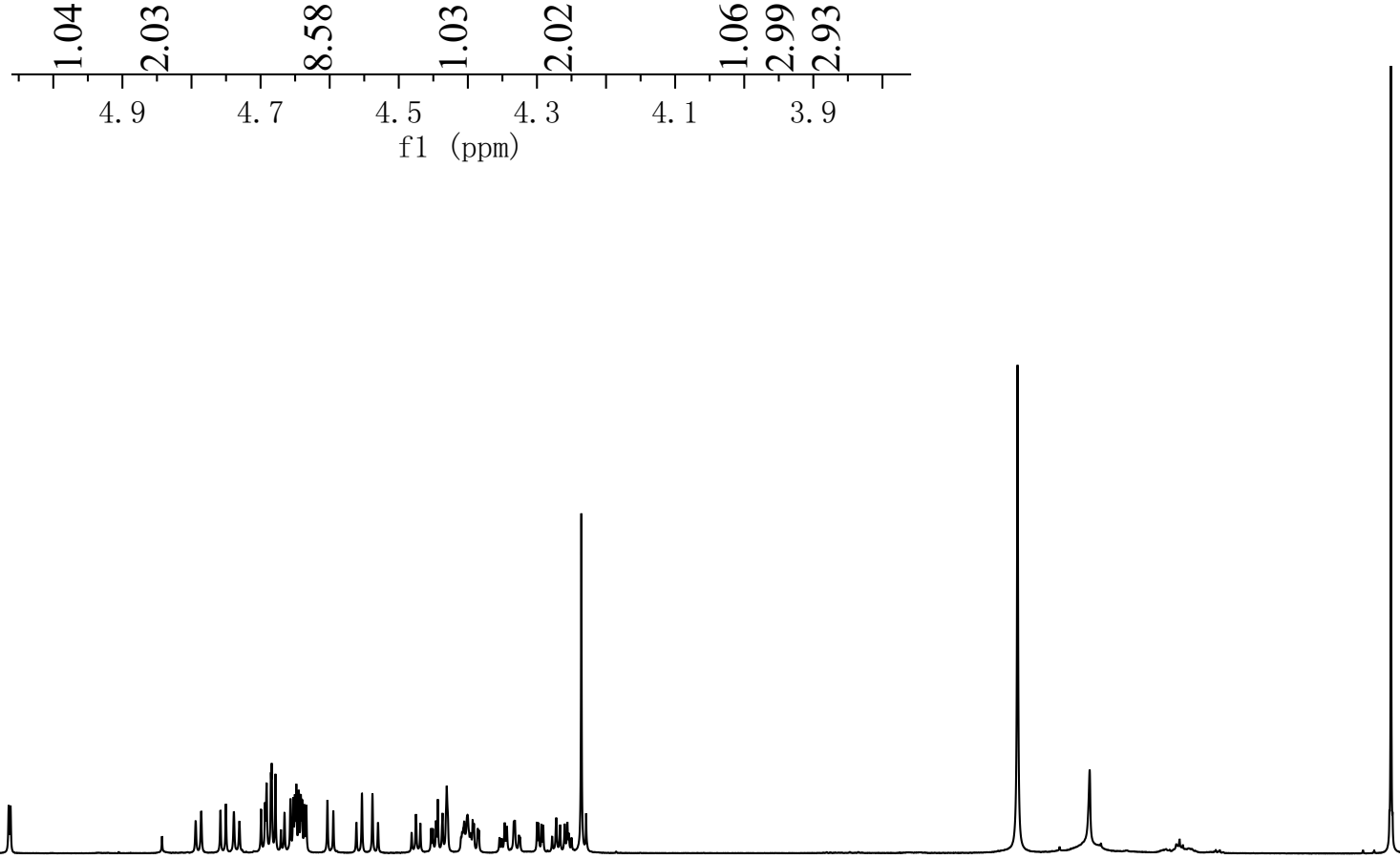

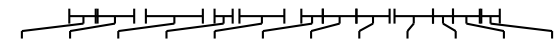

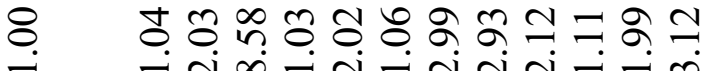

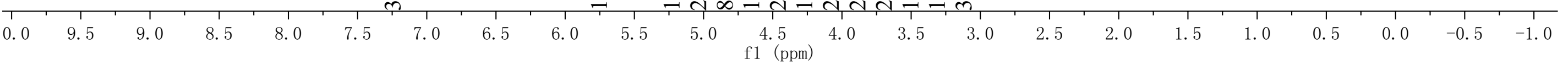




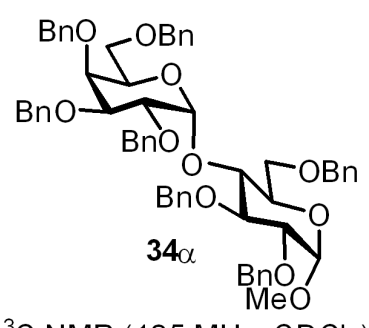

${ }^{13} \mathrm{C} \mathrm{NMR}\left(125 \mathrm{MHz}, \mathrm{CDCl}_{3}\right)$

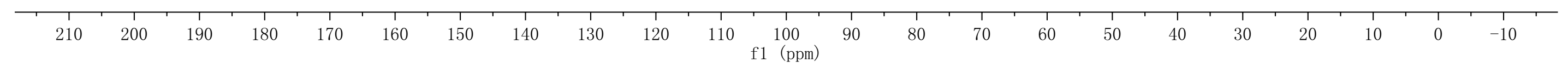




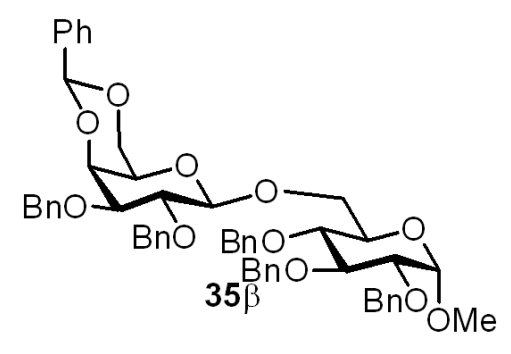

${ }^{1} \mathrm{HNMR}\left(500 \mathrm{MHz}, \mathrm{CDCl}_{3}\right)$
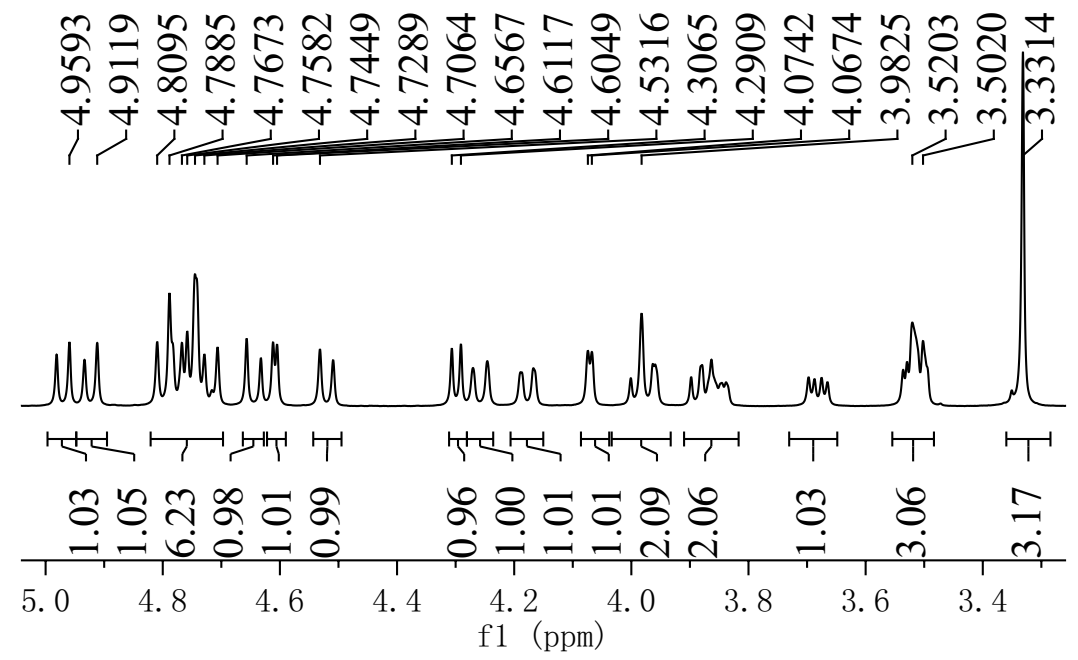

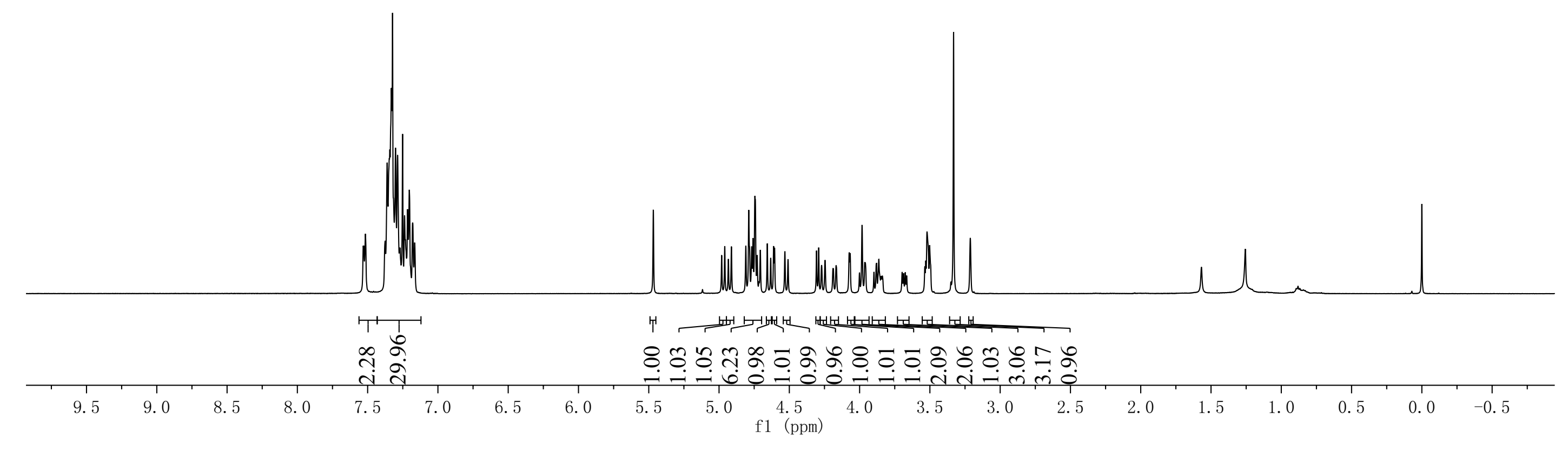




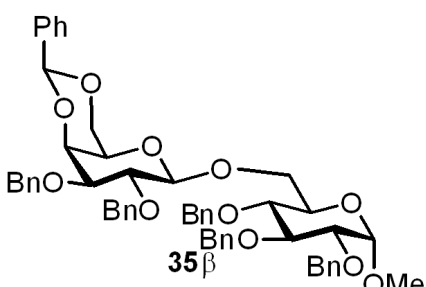

$\left.{ }^{13} \mathrm{C} \mathrm{NMR} \mathrm{(125} \mathrm{MHz,} \mathrm{CDCl}_{3}\right)$

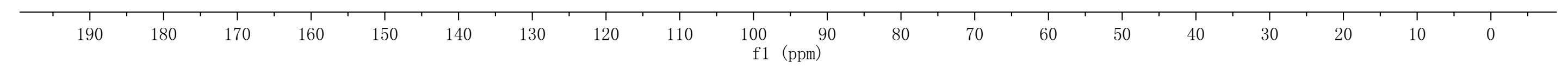




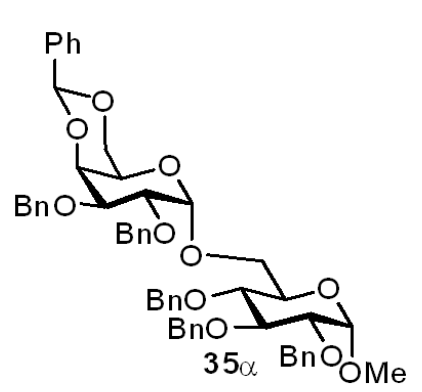

${ }^{1} \mathrm{H} \mathrm{NMR}\left(500 \mathrm{MHz}, \mathrm{CDCl}_{3}\right)$

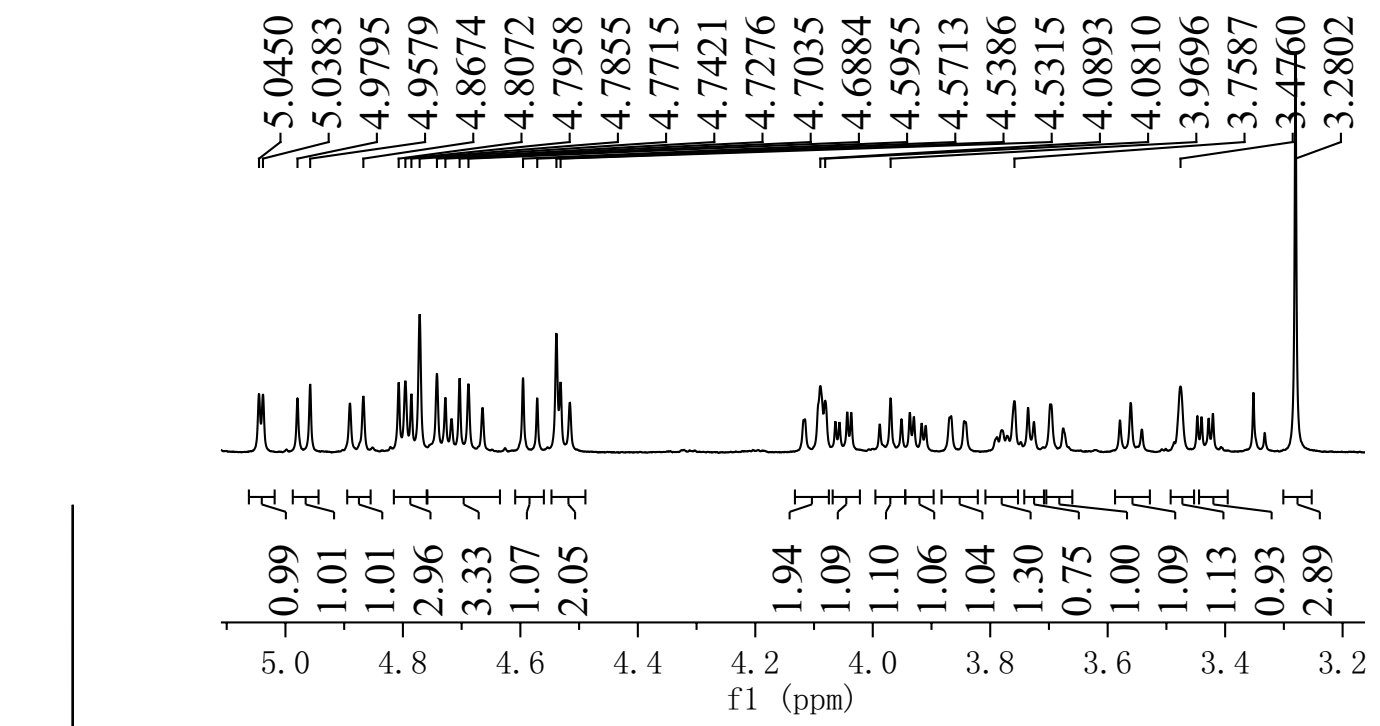

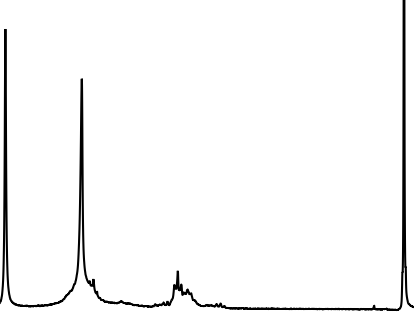

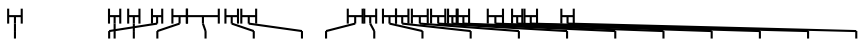

\&

ำ

${ }_{5}{ }_{5.0}{ }_{4.5}{ }_{4.0}{ }_{4.5}{ }_{3.0}{ }_{3 .}$ 


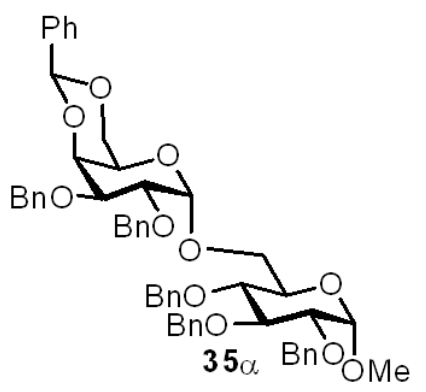

${ }^{13} \mathrm{C} \mathrm{NMR}\left(125 \mathrm{MHz}, \mathrm{CDCl}_{3}\right)$

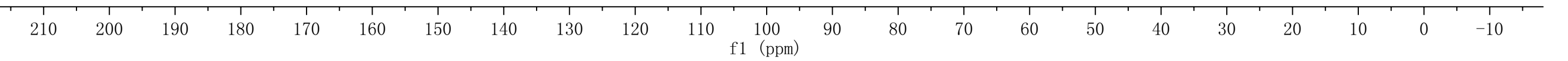



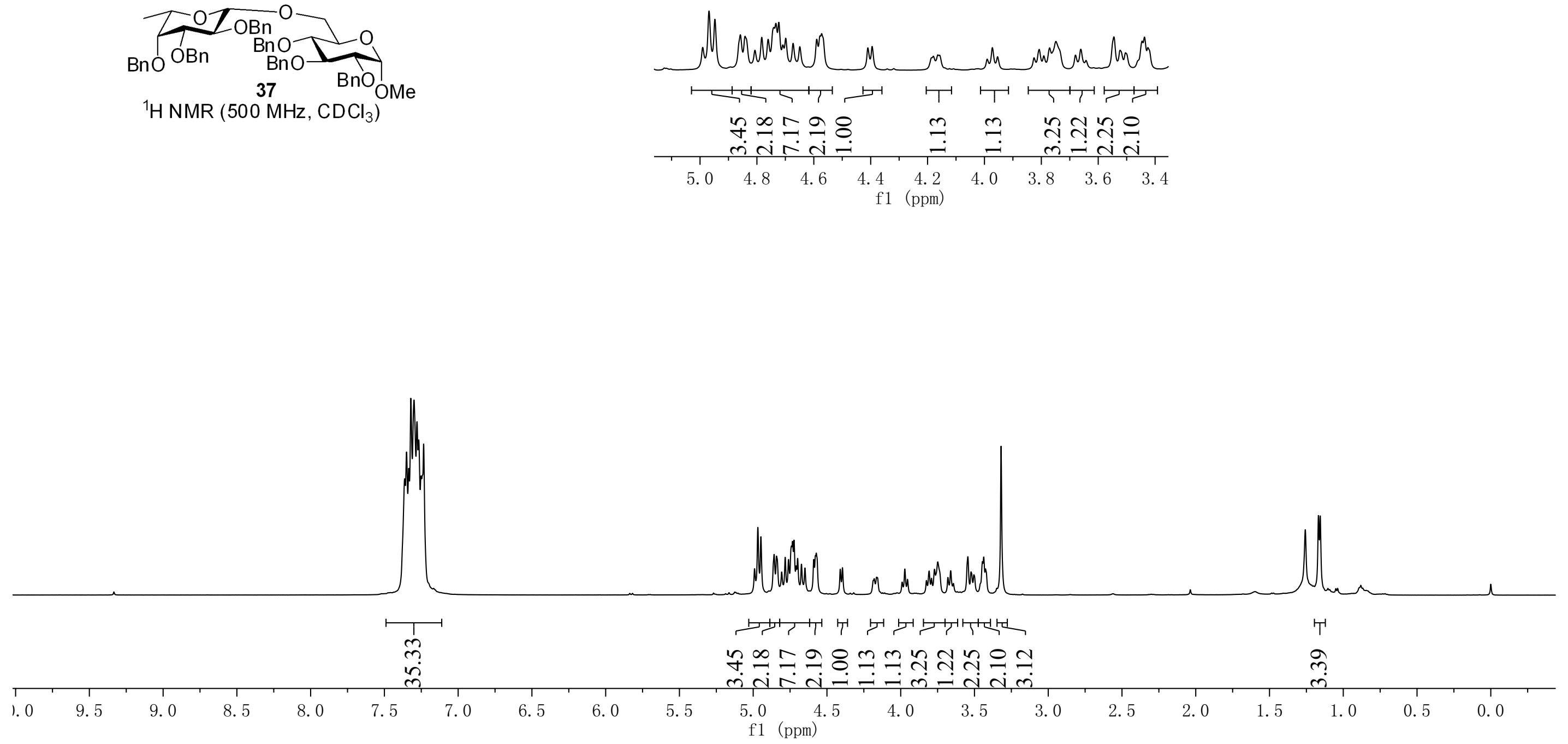


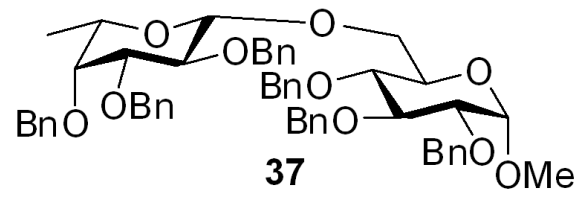

${ }^{13} \mathrm{C} \mathrm{NMR}\left(125 \mathrm{MHz}, \mathrm{CDCl}_{3}\right)$

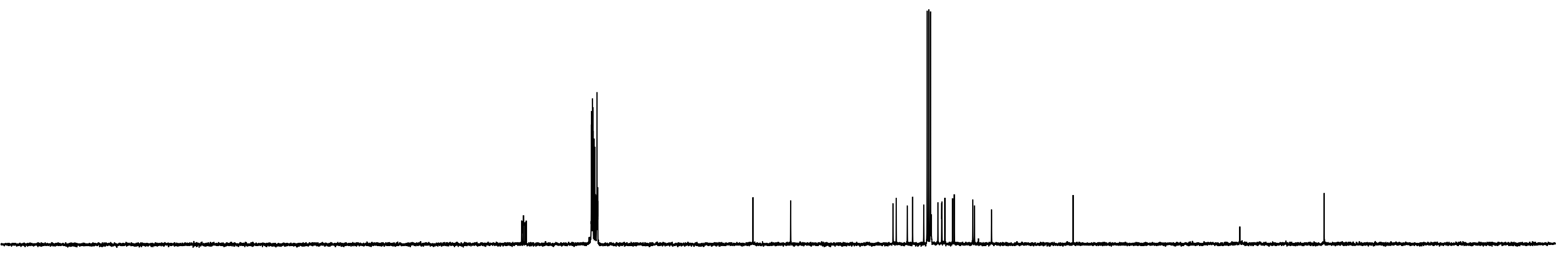

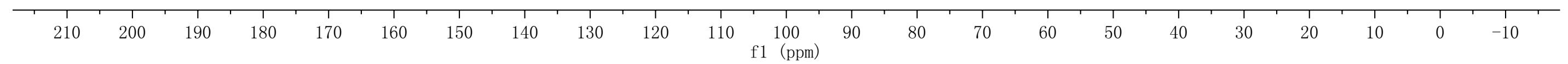




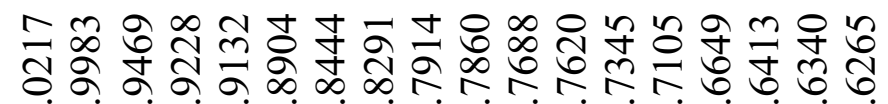

iि
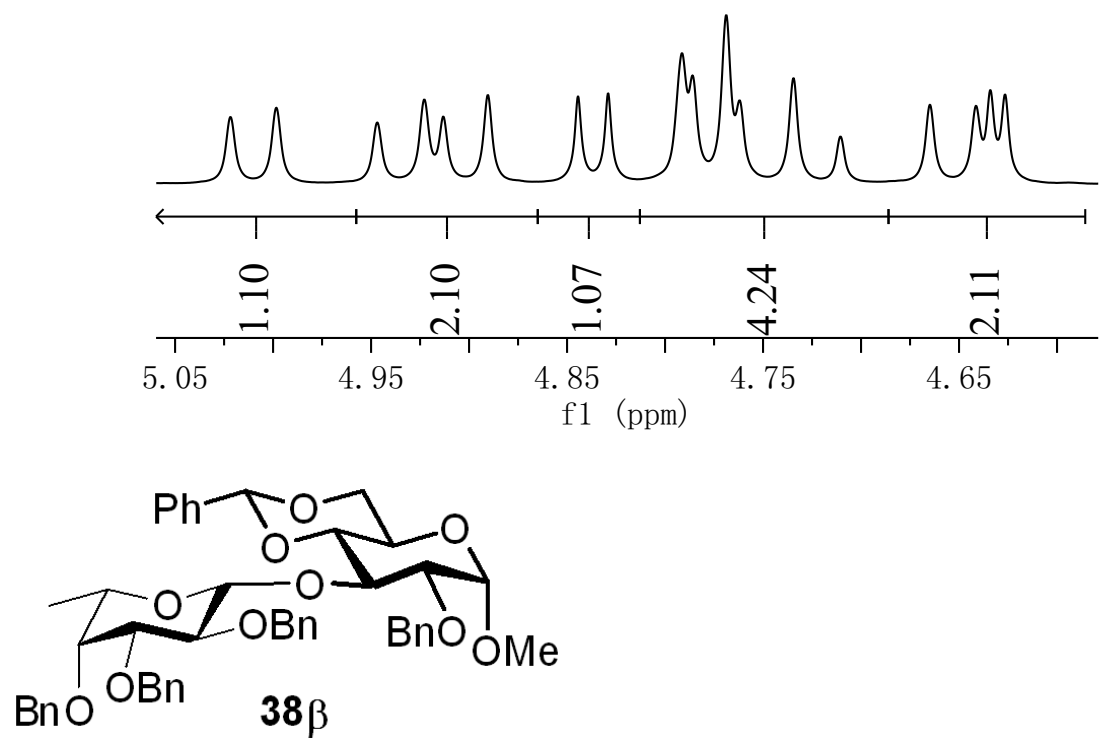

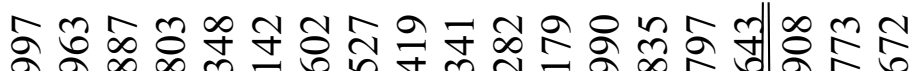
2.

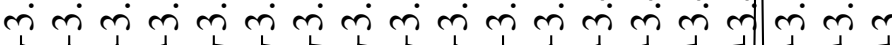

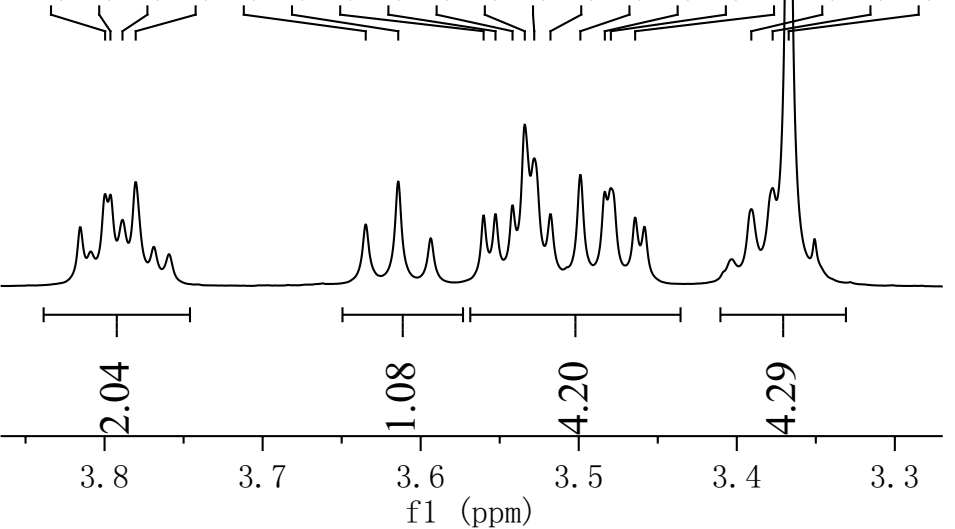

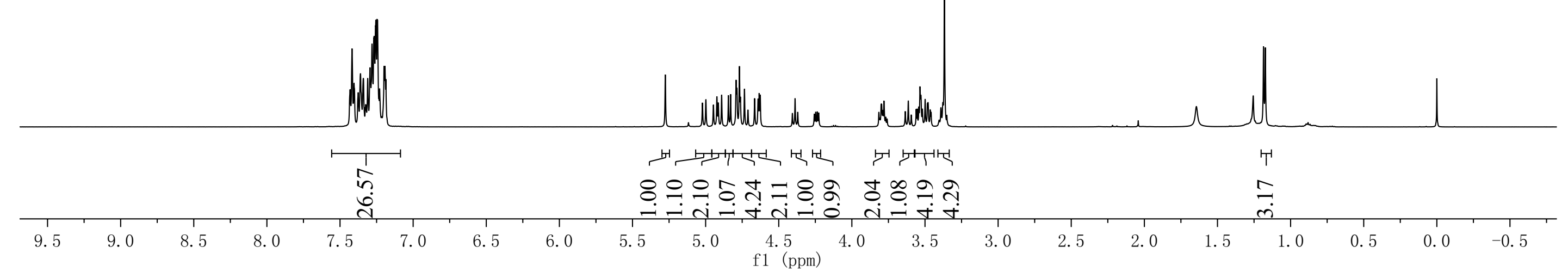



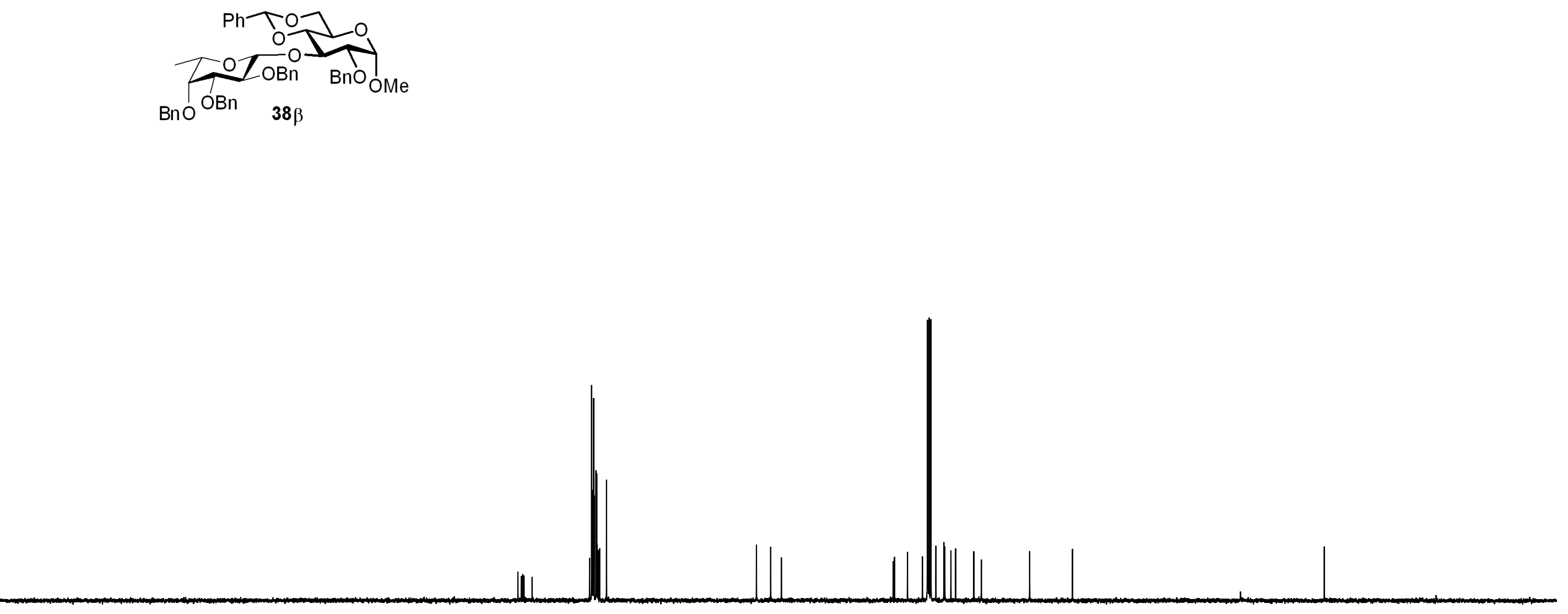

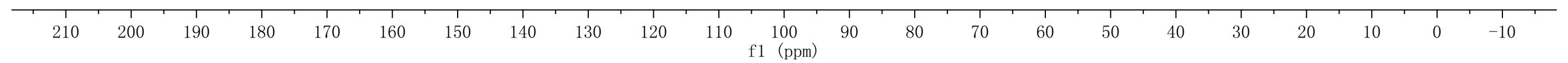




\section{1.}
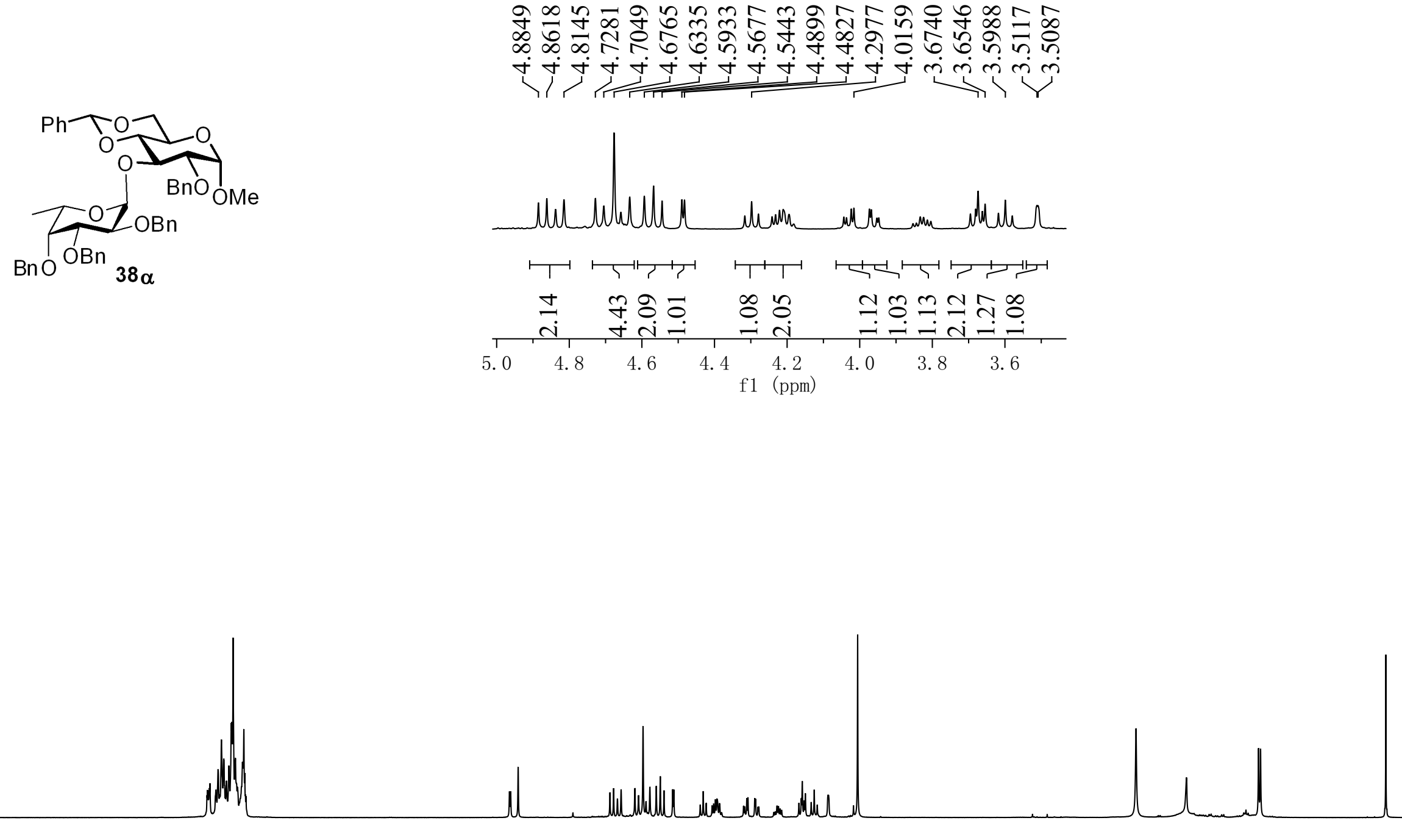

माप

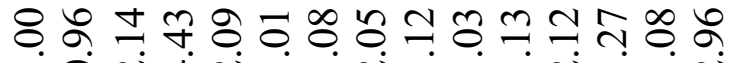

$9.5 \quad 9.0 \quad 8.5 \quad 8.0 \quad 7.5$

7. 0

6. 5

5.5

5. 0

4.5

4. $0 \quad 3.5$

$\begin{array}{llll}3.0 & 2.5 & 2.0 & 1.5\end{array}$




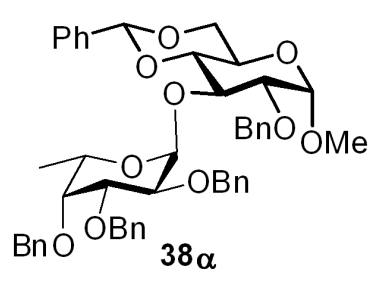

(1)

$\mathrm{BnO}{ }^{\mathrm{OBn}} 38 \mathrm{a}$ 


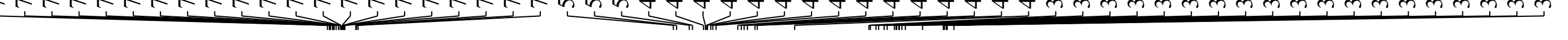

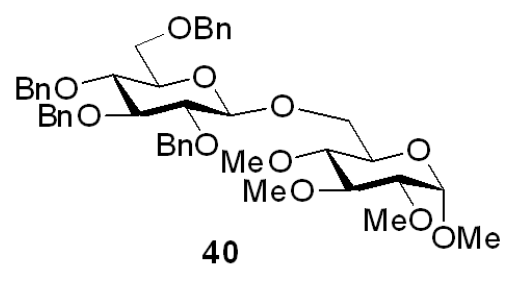

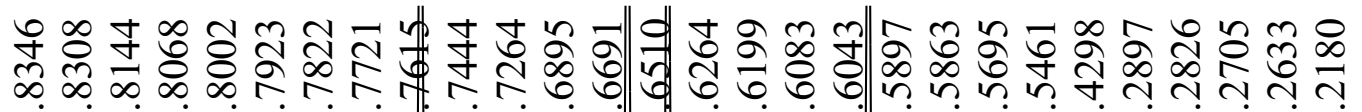

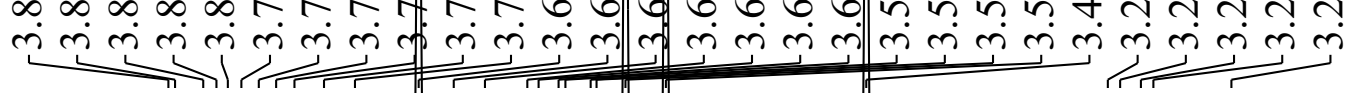

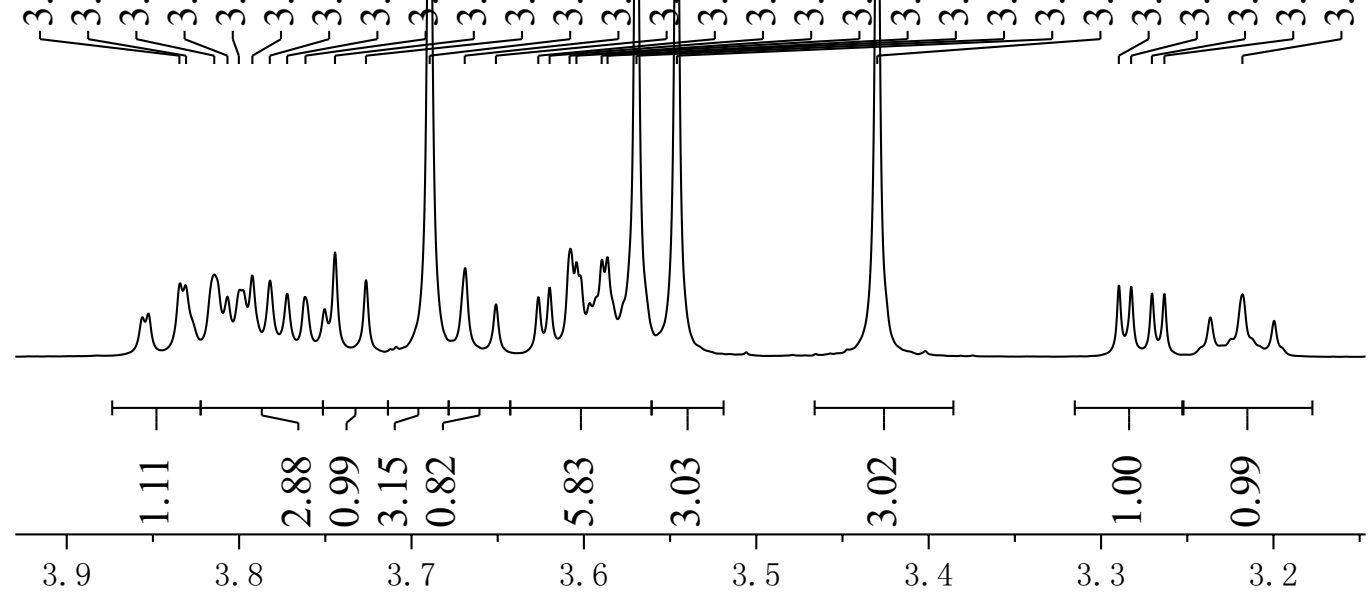

f1 (ppm)

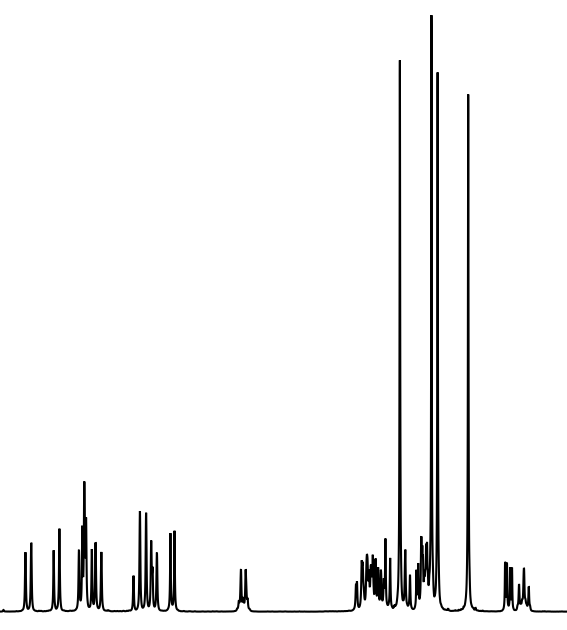

1

$\sum_{\substack{0 \\ \hline}}^{\circ}$

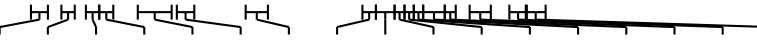

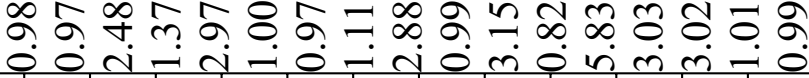

$1=$

7. 0

6.5

6. 0

5.5

5.0

\begin{abstract}
f1 $\stackrel{4.5}{(\mathrm{ppm})}$
\end{abstract}
2.5

$2.0 \quad 1.5$ 

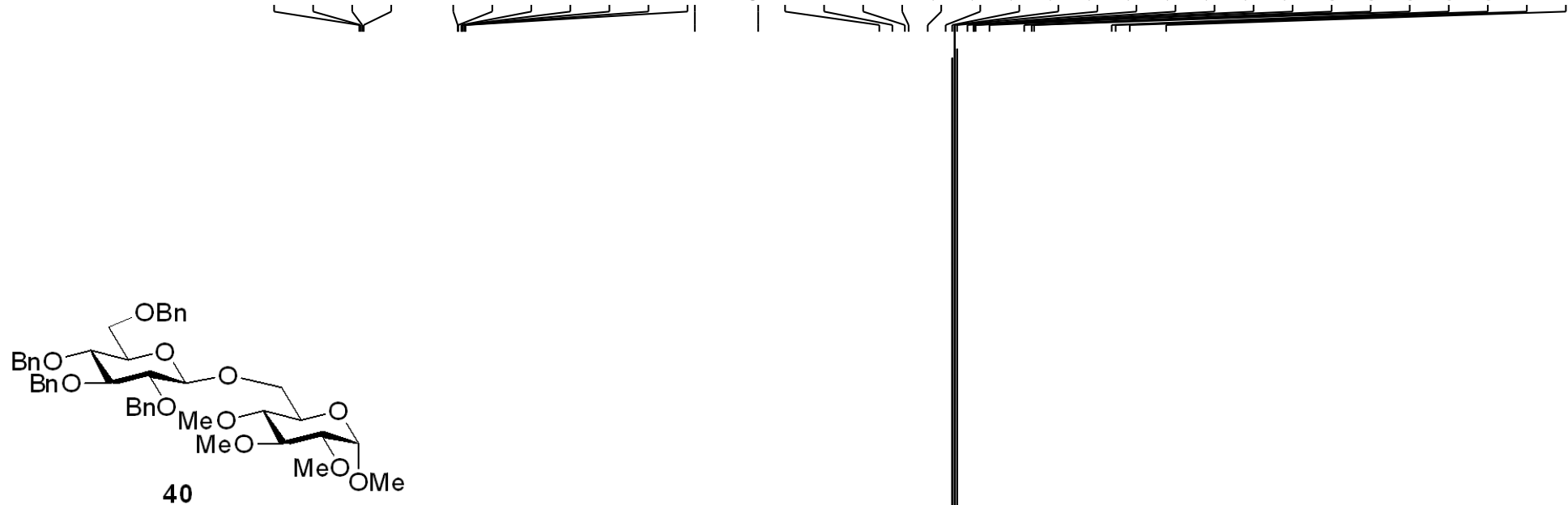


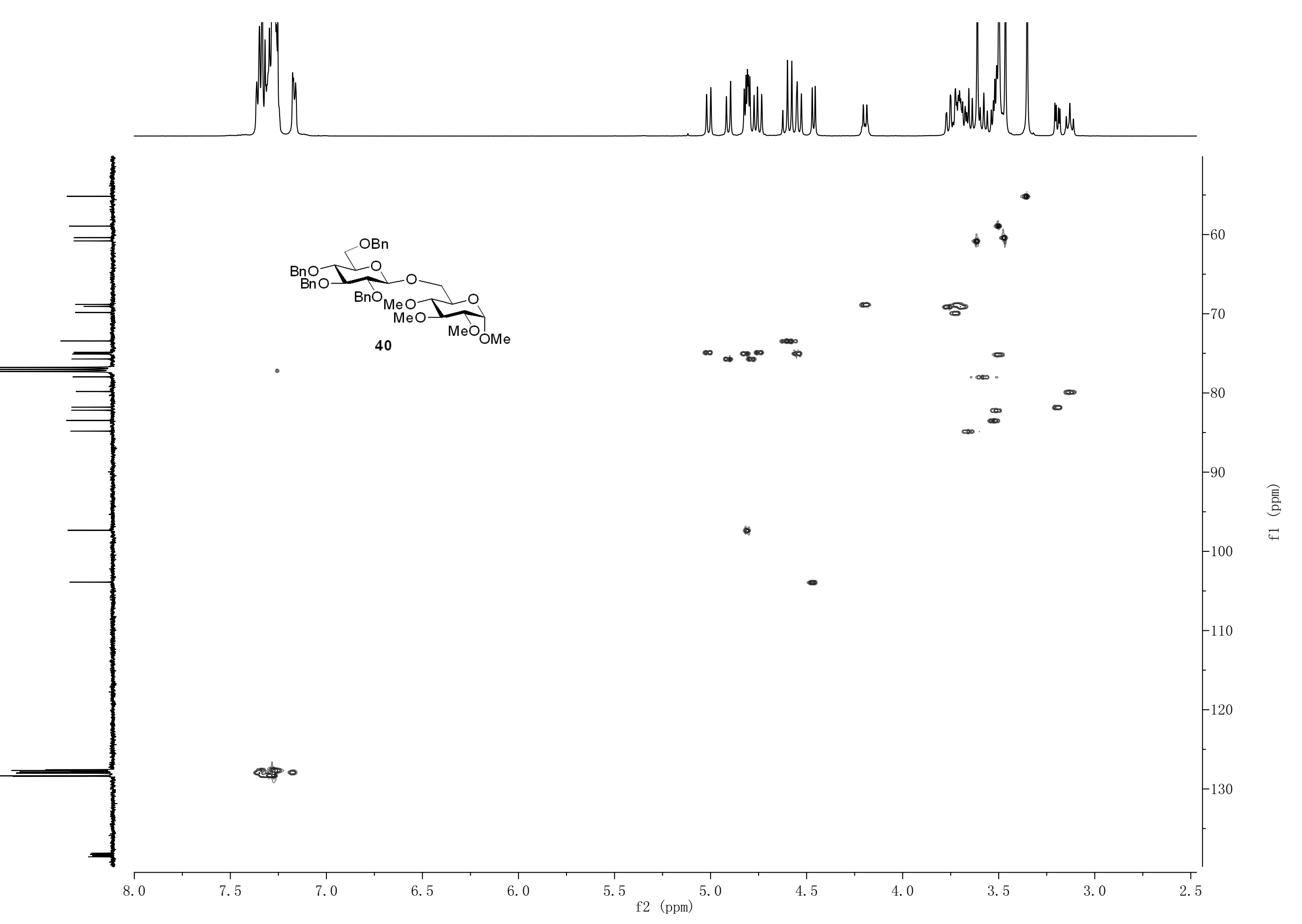




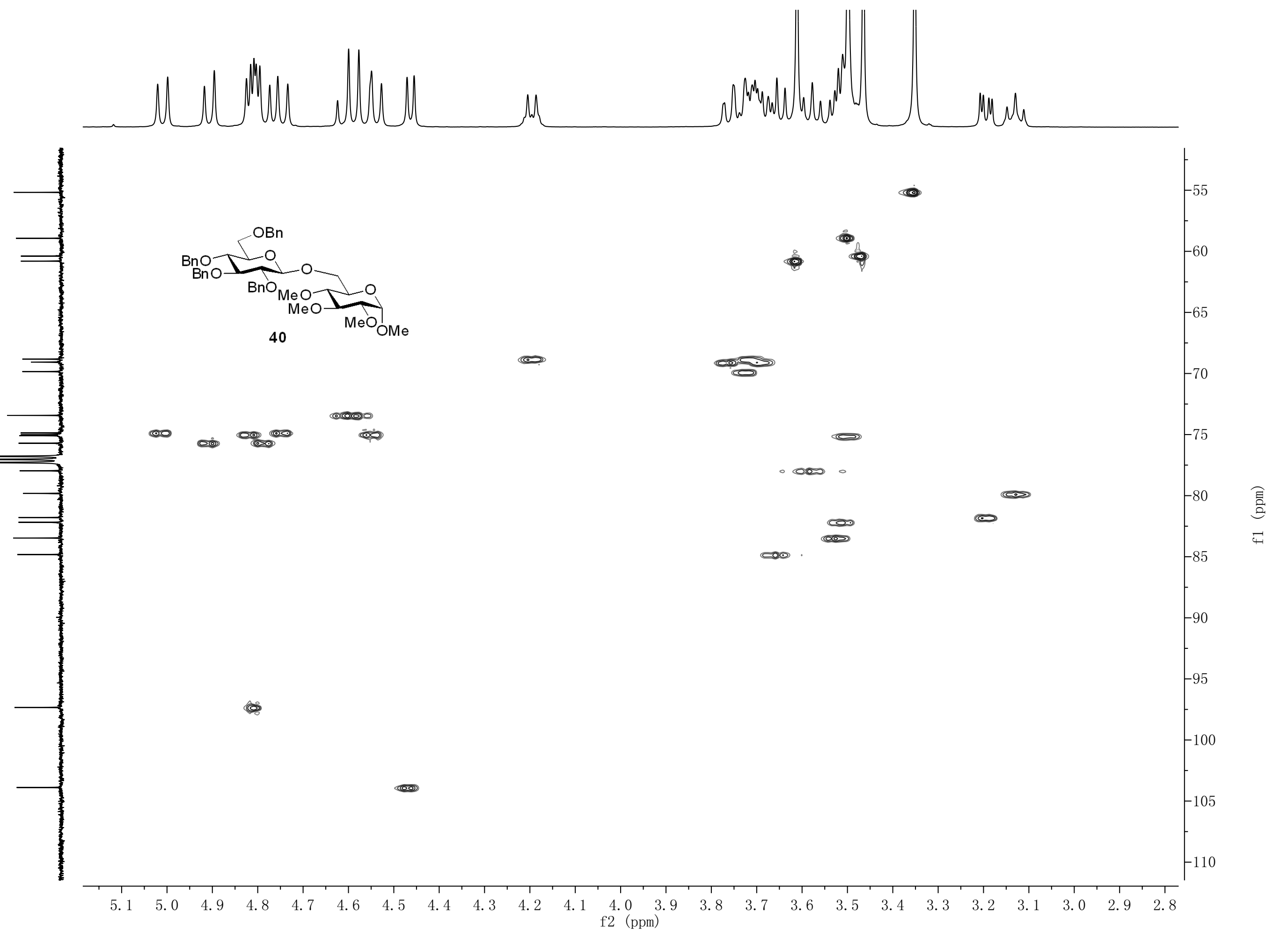




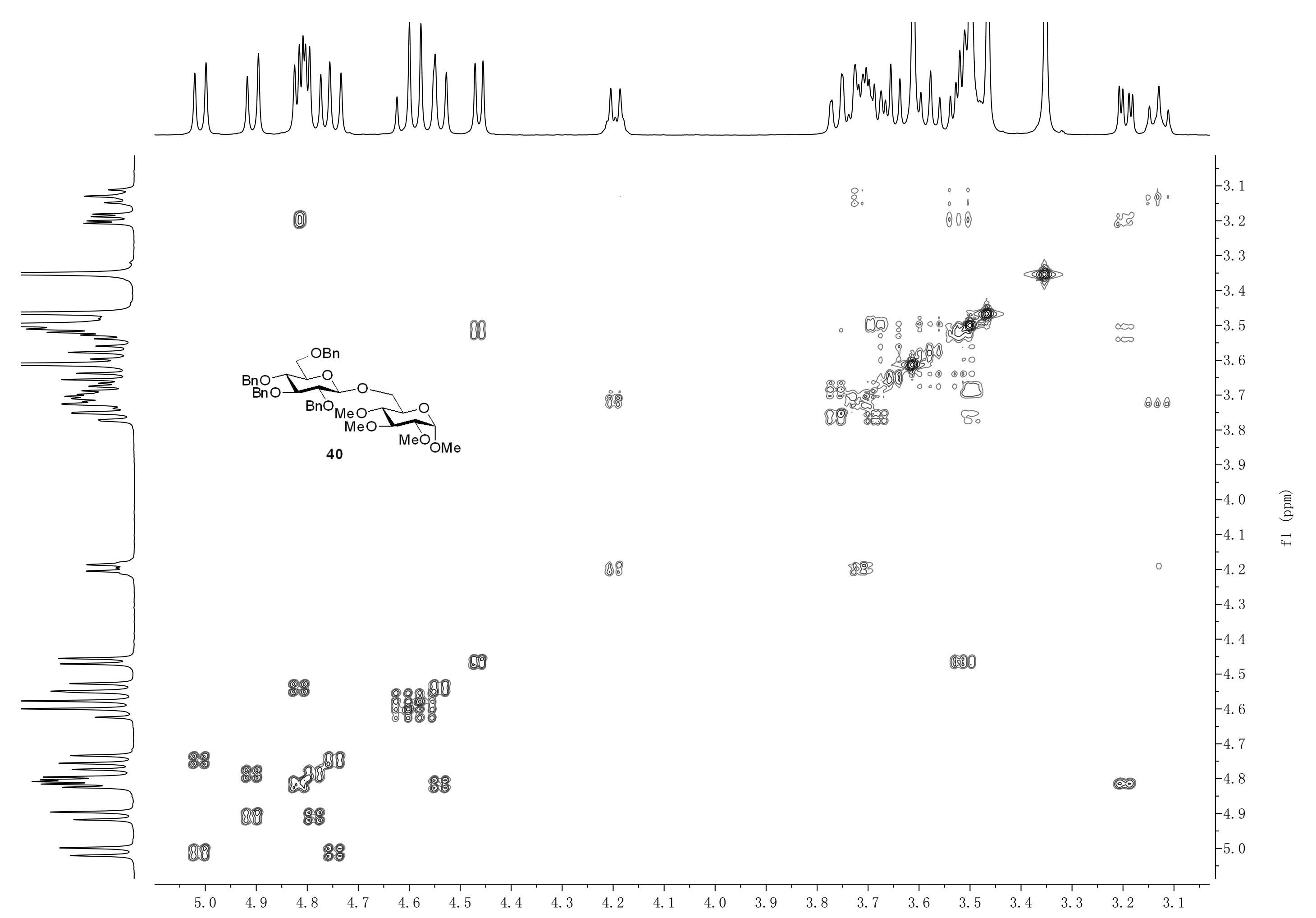




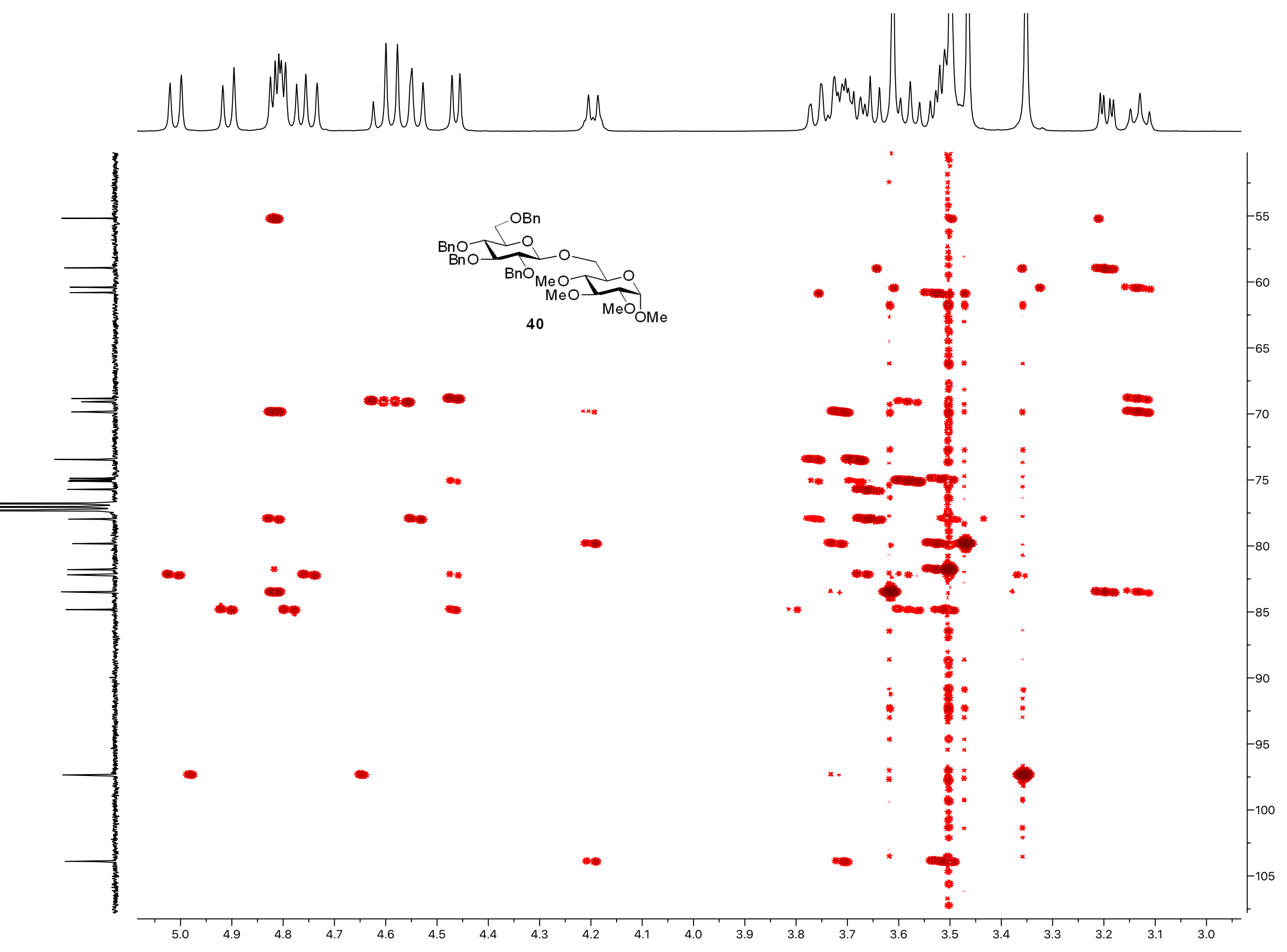

